\title{
Caddo Ceramic Vessels from the Goode Hunt (41CS23) and Clements (41CS25) Sites in the East Texas Pineywoods
}

Timothy K. Perttula

Heritage Research Center, Stephen F. Austin State University

Follow this and additional works at: https://scholarworks.sfasu.edu/ita

Part of the American Material Culture Commons, Archaeological Anthropology Commons, Environmental Studies Commons, Other American Studies Commons, Other Arts and Humanities Commons, Other History of Art, Architecture, and Archaeology Commons, and the United States History Commons

Tell us how this article helped you.

This Article is brought to you for free and open access by the Center for Regional Heritage Research at SFA ScholarWorks. It has been accepted for inclusion in Index of Texas Archaeology: Open Access Gray Literature from the Lone Star State by an authorized editor of SFA ScholarWorks. For more information, please contact cdsscholarworks@sfasu.edu. 
Caddo Ceramic Vessels from the Goode Hunt (41CS23) and Clements (41CS25) Sites in the East Texas Pineywoods

\section{Creative Commons License}

\section{(c) (1) \&}

This work is licensed under a Creative Commons Attribution-NonCommercial 4.0 International License 


\title{
Caddo Ceramic Vessels from the Goode Hunt (41CS23) and Clements (41CS25) Sites in the East Texas Pineywoods
}

\author{
Timothy K. Perttula
}

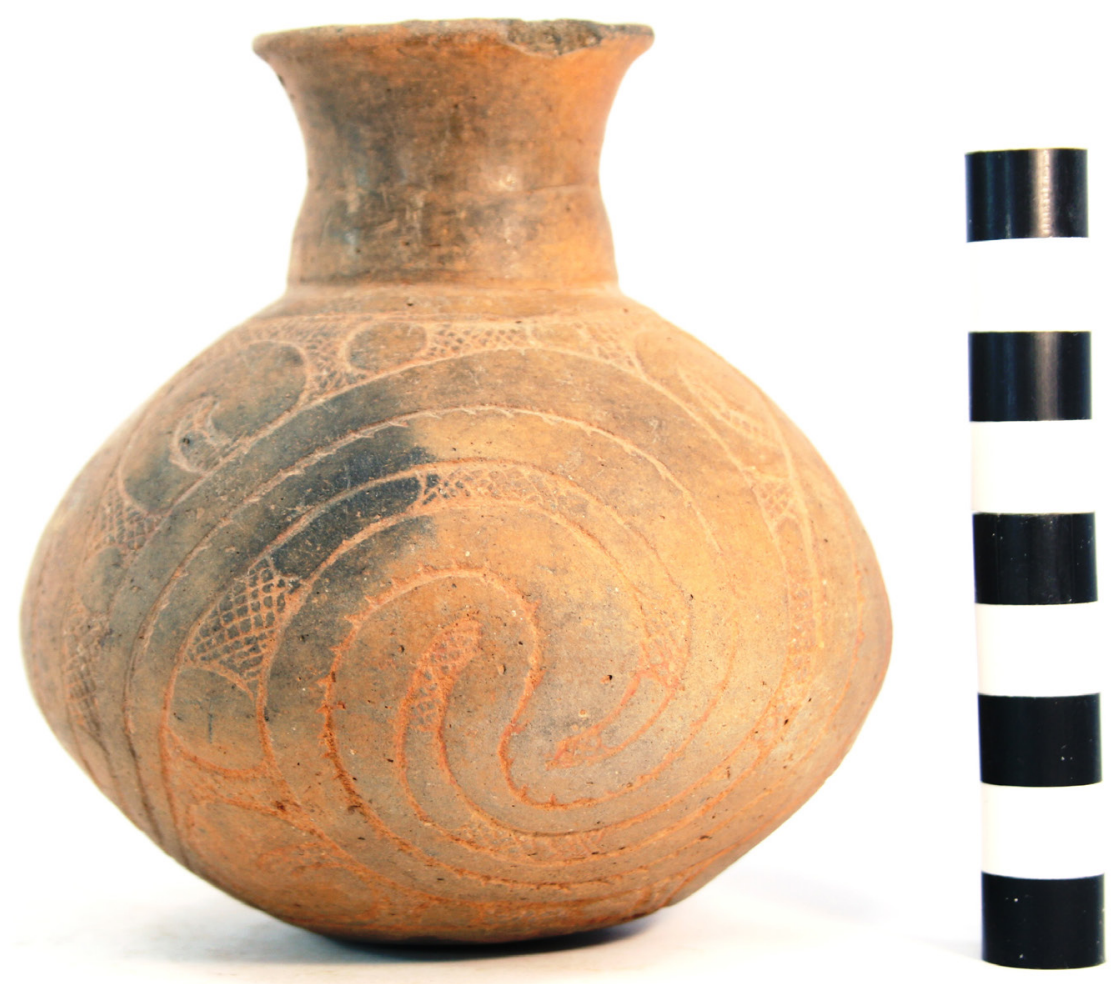

Special Publication No. 42

Friends of Northeast Texas Archaeology, Austin and Pittsburg 

Friends of Northeast Texas Archaeology Editor, Timothy K. Perttula 10101 Woodhaven Dr. Austin, Texas 78753 tkp4747@aol.com

\section{Friends of Northeast Texas Archaeology, Distribution, Bo Nelson, 344 CR 4154 \\ Pittsburg, Texas 75686 \\ RBoNelson@aol.com}

Cover art: Hodges Engraved bottle from the Goode Hunt site (41CS23), Cass County, Texas

Copyright (C) 2015, Friends of Northeast Texas Archaeology

(Pittsburg and Austin) 


\section{Table of Contents}

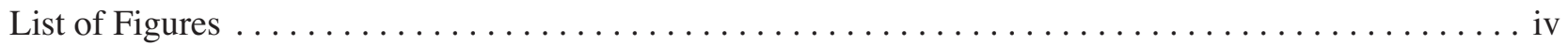

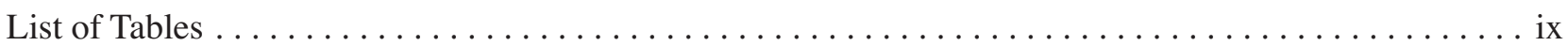

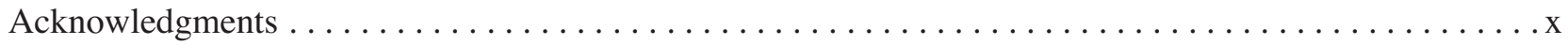

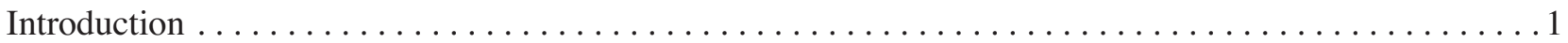

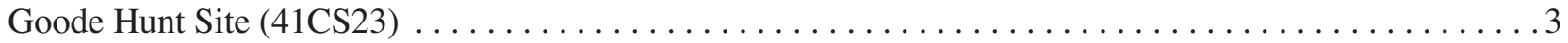

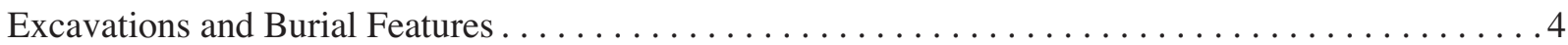

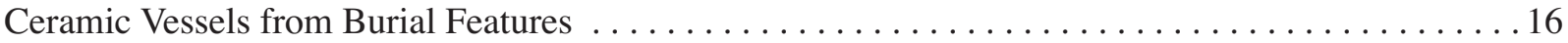

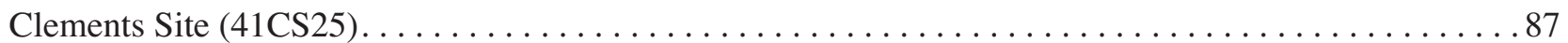

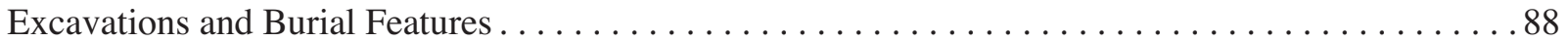

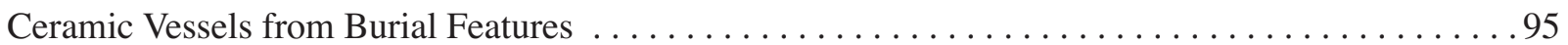

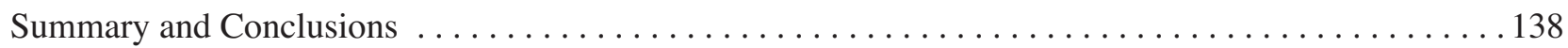

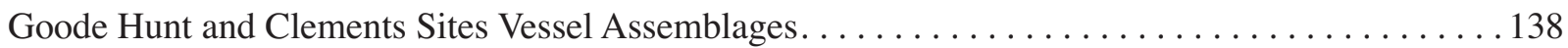

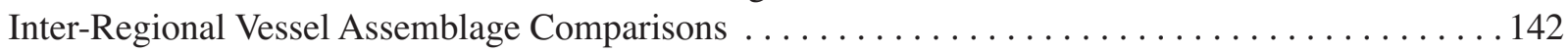

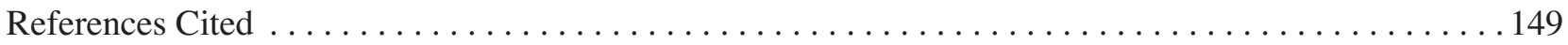




\section{List of Figures}

1. The location of the Goode Hunt and Clements sites in East Texas, and the location

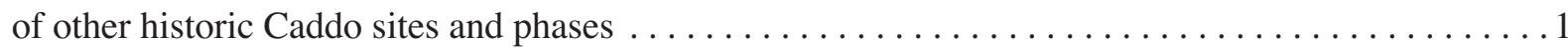

2. Map of the Goode Hunt site and vicinity (from Jackson 1932b:47) . . . . . . . . . . . 3

3. 1932 excavations at the Goode Hunt site and the location of ancestral Caddo burial features, a dog burial, and a single isolated ceramic vessel (after Jackson 1932b:46) . . . . . . . . . . . . 4

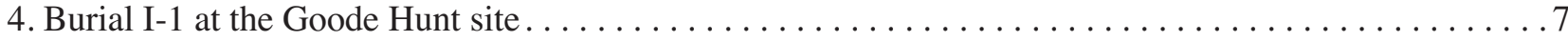

5. Ceramic elbow pipe (No. 11) in Burial I-1 at the Goode Hunt site . . . . . . . . . . . . . . . 7

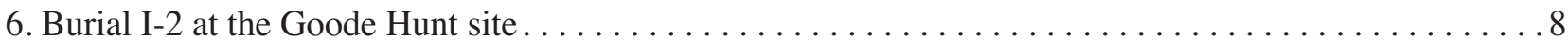

7. Burial I-3 at the Goode Hunt site . . . . . . . . . . . . . . . . . . . . . . . . . . . . . .99

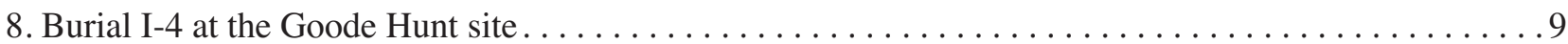

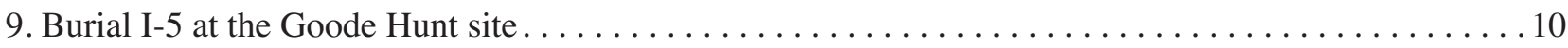

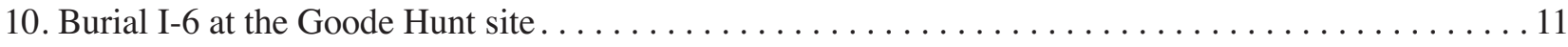

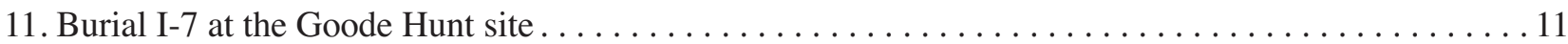

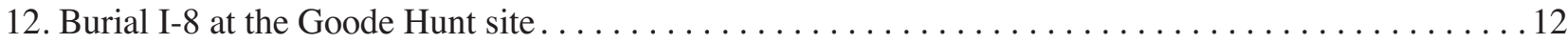

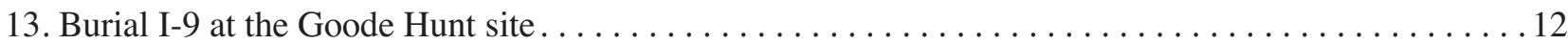

14. Burial I-10 at the Goode Hunt site: a, plan of the burial; b, drawing of Vessel No. 74

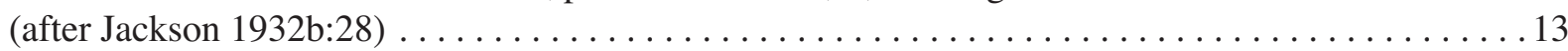

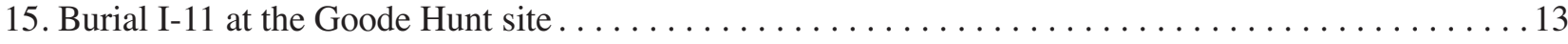

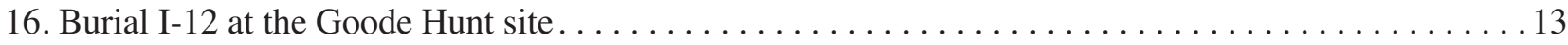

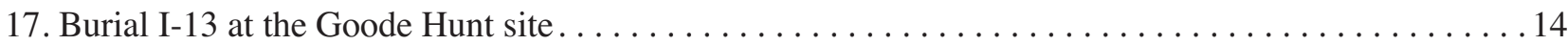

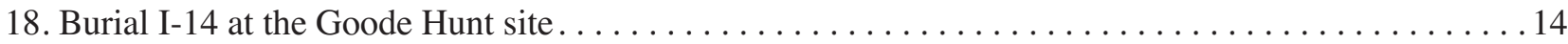

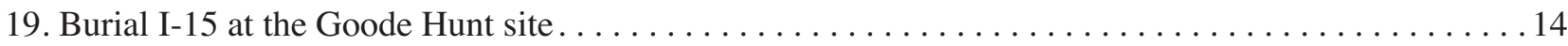

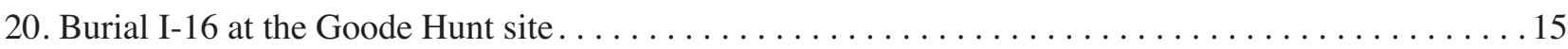

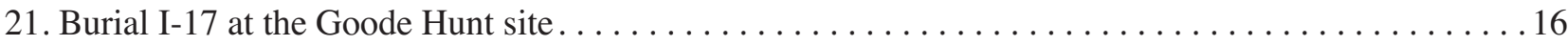

22. cf. Simms Engraved carinated bowl (Vessel No. 1) from the Goode Hunt site, possibly

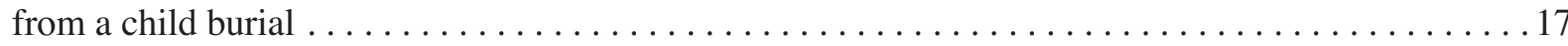

23. Hatchel Engraved bottle (Vessel No. 12) from Burial I-1 at the Goode Hunt site . . . . . . . . . . 18

24. Hodges Engraved bottle (Vessel No. 14) from Burial I-2 at the Goode Hunt site. . . . . . . . . . . . . 19

25. Simms Engraved carinated bowl (Vessel No. 15) from Burial I-2 at the Goode Hunt site . . . . . . . 20

26. Foster Trailed-Incised, var. Moore jar (Vessel No. 16) from Burial I-2 at the Goode Hunt site . . . . . 21

27. Hodges Engraved carinated bowl (Vessel No. 18) from Burial I-2 at the Goode Hunt site . . . . . . . 22

28. Mockingbird Punctated jar (Vessel No. 19) in Burial I-2 at the Goode Hunt site ............... 23 
29. Hodges Engraved bottle (Vessel No. 21) from Burial I-3 at the Goode Hunt site. . . . . . . . . . . 24

30. Taylor Engraved carinated bowl (Vessel No. 22) from Burial I-3 at the Goode Hunt site . . . . . . . 25

31. Keno Trailed, var. Phillips bowl (Vessel No. 23) from Burial I-3 at the Goode Hunt site . . . . . ... 26

32. Simms Engraved, var. Darco carinated bowl (Vessel No. 24) from Burial I-3

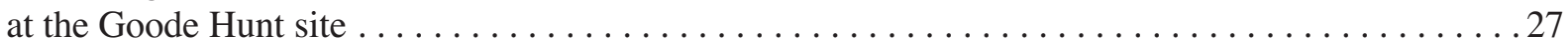

33. Simms Engraved carinated bowl (Vessel No. 25) from Burial I-3 at the Goode Hunt site . . . . . . . . 28

34. Plain jar (Vessel No. 26) from Burial I-3 at the Goode Hunt site . . . . . . . . . . . . . . . . . . 29

35. Hodges Engraved bottle (Vessel No. 35) from Burial I-4 at the Goode Hunt site . . . . . . . . . . . 30

36. Simms Engraved, var. Darco carinated bowl (Vessel No. 35) from Burial I-4

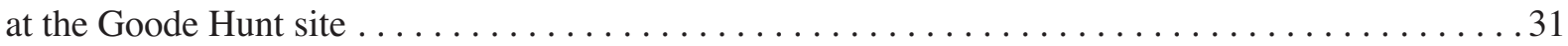

37. Simms Engraved carinated bowl (Vessel No. 36) in Burial I-4 at the Goode Hunt site . . . . . . . . . 32

38. Engraved compound bowl (Vessel No. 38) from the dog burial at the Goode Hunt site............33

39. cf. Simms Engraved carinated bowl (Vessel No. 41) in Burial I-5 at the Goode Hunt site........... 34

40. cf. Pease Brushed-Incised jar (Vessel No. 42) from Burial I-5 at the Goode Hunt site. . . . . . . . . . 35

41. Simms Engraved carinated bowl (Vessel No. 43) in Burial I-5 at the Goode Hunt site . . . . . . . . . 36

42. Simms Engraved carinated bowl (Vessel No. 44) in Burial I-5 at the Goode Hunt site ........... 37

43. Simms Engraved carinated bowl (Vessel No. 45) in Burial I-5 at the Goode Hunt site ........... 38

44. Simms Engraved carinated bowl (Vessel No. 46) in Burial I-5 at the Goode Hunt site ... . . . . . . . 39

45. Foster Trailed-Incised, var. Moore jar (Vessel No. 47) in Burial I-5 at the Goode Hunt site . . . . . . . 40

46. Bailey Engraved bottle (Vessel No. 50) in Burial I-6 at the Goode Hunt site . . . . . . . . . . . . 41

47. Engraved bowl (Vessel No. 51) in Burial I-6 at the Goode Hunt site . . . . . . . . . . . . . . 42

48. Hodges Engraved deep bowl (Vessel No. 52) in Burial I-6 at the Goode Hunt site . . . . . . . . . 43

49. Simms Engraved carinated bowl (Vessel No. 58) in Burial I-7 at the Goode Hunt site . . . . . . . . 44

50. Simms Engraved carinated bowl (Vessel No. 59) in Burial I-7 at the Goode Hunt site ...........45

51. Maydelle Incised jar (Vessel No. 60) in Burial I-7 at the Goode Hunt site . . . . . . . . . . . . 46

52. Karnack Brushed-Incised jar (Vessel No. 63a) in Burial I-8 at the Goode Hunt site . . . . . . . . . 47

53. Plain jar (Vessel No. 63b) in Burial I-8 at the Goode Hunt site . . . . . . . . . . . . . . . 48

54. Engraved carinated bowl (Vessel No. 64) in Burial I-8 at the Goode Hunt site . . . . . . . . . . . . 49

55. Hodges Engraved bottle (Vessel No. 65) in Burial I-9 at the Goode Hunt site . . . . . . . . . . . . 50

56. Engraved carinated bowl (Vessel No. 66) in Burial I-9 at the Goode Hunt site . . . . . . . . . . . 51

57. Mockingbird Punctated jar (Vessel No. 68) in Burial I-9 at the Goode Hunt site . . . . . . . . . . . 52

58. Maydelle Incised jar (Vessel No. 69) in Burial I-9 at the Goode Hunt site . . . . . . . . . . . . 53

59. Plain jar (Vessel No. 75) in Burial I-10 at the Goode Hunt site . . . . . . . . . . . . . . . . 54

60. Brushed jar (Vessel No. 76) in Burial I-11 at the Goode Hunt site . . . . . . . . . . . . . . 55 
61. cf. Keno Trailed bottle (Vessel No. 77) in Burial I-11 at the Goode Hunt site . . . . . . . . . . .56

62. cf. Simms Engraved carinated bowl (Vessel No. 78) in Burial I-11 at the Goode Hunt site. . . . . . . 57

63. Engraved compound bowl (Vessel No. 79) in Burial I-12 at the Goode Hunt site . . . . . . . . . 58

64. Plain jar (Vessel No. 80) in Burial I-12 at the Goode Hunt site. . . . . . . . . . . . . . . . . 59

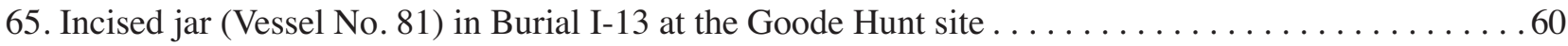

66. cf. Karnack Brushed-Incised jar (Vessel No. 82) in Burial I-14 at the Goode Hunt site . . . . . . . . .61

67. Incised-punctated jar (Vessel No. 83) in Burial I-14 at the Goode Hunt site . . . . . . . . . . . . 62

68. Keno Trailed, var. Phillips bowl (Vessel No. 85) in Burial I-14 at the Goode Hunt site. . . . . . . . 63

69. Incised jar (Vessel No. 86) in Burial I-14 at the Goode Hunt site . . . . . . . . . . . . . . 64

70. Plain shell-tempered jar (Vessel No. 87) in Burial I-14 at the Goode Hunt site . . . . . . . . . . .65

71. Simms Engraved carinated bowl (Vessel No. 88) in Burial I-14 at the Goode Hunt site ...........66

72. Taylor Engraved carinated bowl (Vessel No. 89) in Burial I-14 at the Goode Hunt site. . . . . . . . . 67

73. Appliqued jar (Vessel No. 90) in Burial I-14 at the Goode Hunt site . . . . . . . . . . . . . 68

74. Simms Engraved carinated bowl (Vessel No. 98) in Burial I-15 at the Goode Hunt site . . . . . . . . 69

75. Pease Brushed-Incised jar (Vessel No. 99) in Burial I-15 at the Goode Hunt site . . . . . . . . . . 70

76. Hodges Engraved bottle (Vessel No. 100) in Burial I-15 at the Goode Hunt site . . . . . . . . . . .71

77. Engraved carinated bowl (Vessel No. 101) in Burial I-15 at the Goode Hunt site . . . . . . . . . . . 72

78. Moore Noded bowl that had appliqued rattle knobs (Vessel No. 102) in Burial I-15

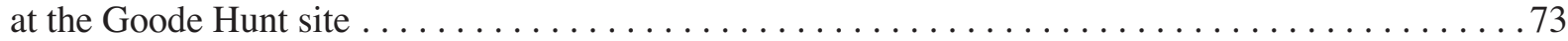

79. Plain jar with suspension holes (Vessel No. 104) in Burial I-15 at the Goode Hunt site . . . . . . . . 74

80. Brushed-appliqued jar (Vessel No. 105) in Burial I-15 at the Goode Hunt site . . . . . . . . . . 75

81. Brushed-appliqued jar (Vessel No. 106) in Burial I-15 at the Goode Hunt site . . . . . . . . . . 76

82. Simms Engraved carinated bowl (Vessel No. 108) in Burial I-16 at the Clements site . . . . . . . . 77

83. cf. Hatchel Engraved bottle (Vessel No. 109) in Burial I-16 at the Goode Hunt site . . . . . . . . . . 78

84. Simms Engraved, var. Darco compound bowl (Vessel No. 110) in Burial I-16

at the Goode Hunt site . . . . . . . . . . . . . . . . . . . . . . . . . . 79

85. Simms Engraved carinated bowl (Vessel No. 111) in Burial I-16 at the Goode Hunt site ........ 80

86. Hudson Engraved deep bowl (Vessel No. 112) in Burial I-16 at the Goode Hunt site . . . . . . . . 81

87. cf. Pease Brushed-Incised jar (Vessel No. 113) in Burial I-16 at the Goode Hunt site . . . . . . . . . 82

88. Hodges Engraved bottle (Vessel No. 121) in Burial I-17 at the Goode Hunt site . . . . . . . . . . 83

89. Simms Engraved carinated bowl (Vessel No. 122) in Burial I-17 at the Goode Hunt site . . . . . . . 84

90. Brushed-incised and appliqued jar (Vessel No. 123( in Burial I-17 at the Goode Hunt site . . . . . . .85

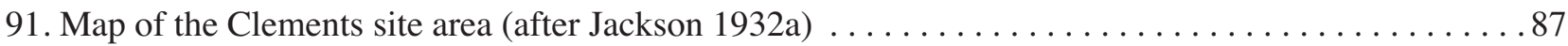

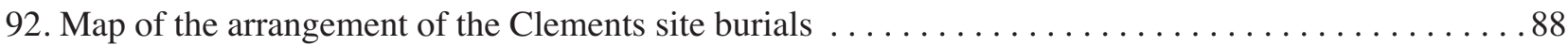


93. Mockingbird Punctated jar (Vessel No. 2) from Burial H-1 at the Clements site . . . . . . . . . 95

94. Mockingbird Punctated jar (Vessel No. 10) from Burial H-2 at the Clements site . . . . . . . . . 96

95. Cass Appliqued jar (Vessel No. 15) from Burial H-3 at the Clements site . . . . . . . . . . . . 97

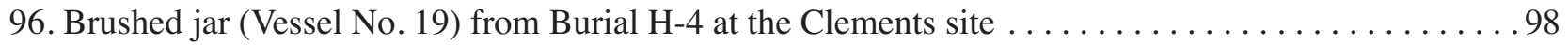

97. Clements Brushed olla (Vessel No. 20) from Burial H-4 at the Clements site . . . . . . . . . . . . 99

98. Cass Appliqued jar (Vessel No. 22) from Burial H-4 at the Clements site . . . . . . . . . . . . 100

99. Karnack Brushed-Incised rim and body sherds (Vessel No. 26) from Burial H-4, Clements site. . . . 101

100. Brushed-punctated jar (Vessel No. 36) from Burial H-6 at the Clements site . . . . . . . . . . 102

101. Engraved-punctated compound bowl (Vessel No. 37) from Burial H-6 at the Clements site . . . . . 103

102. Karnack Brushed-Incised jar (Vessel No. 38) from Burial H-6 at the Clements site . . . . . . . . 104

103. Simms Engraved carinated bowl (Vessel No. 42) from Burial H-7 at the Clements site . . . . . . . 105

104. Incised-punctated jar (Vessel No. 62) from Burial H-8 at the Clements site . . . . . . . . . . 106

105. Hodges Engraved olla (Vessel No. 70) from Burial H-11 at the Clements site . . . . . . . . . . 107

106. Simms Engraved carinated bowl (Vessel No. 71) from Burial H-11 at the Clements site . . . . . . 108

107. Simms Engraved carinated bowl (Vessel No. 73) in Burial H-11 at the Clements site.......... . 109

108. Engraved bowl (Vessel No. 74) from Burial H-11 at the Clements site . . . . . . . . . . 110

109. Nash Neck Banded jar (Vessel No. 77) from Burial H-11 at the Clements site . . . . . . . . . . 111

110. Appliqued jar (Vessel No. 79) from Burial H-11 at the Clements site . . . . . . . . . . . . . 112

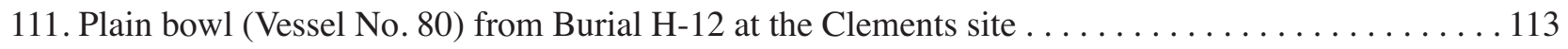

112. Simms Engraved carinated bowl (Vessel No. 81) in Burial H-12 at the Clements site. . . . . . . . 114

113. Hodges Engraved deep bowl (Vessel No. 95) in Burial H-14 at the Clements site ............ 115

114. cf. Emory Punctated-Incised jar (Vessel No. 96) from Burial H-14 at the Clements site . . . . . . . . 116

115. Clements Brushed jar (Vessel No. 97) in Burial H-14 at the Clements site . . . . . . . . . 117

116. cf. Mockingbird Punctated jar (Vessel No. 101) in Burial H-15 at the Clements site ........... 118

117. Taylor Engraved deep bowl (Vessel No. 102) in Burial H-15 at the Clements site. . . . . . . . . . . 119

118. Simms Engraved, var. Darco carinated bowl (Vessel No. 104) in Burial H-15

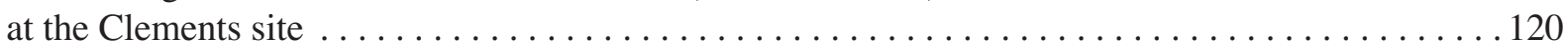

119. Clements Brushed olla (Vessel No. 105a) in Burial H-15 at the Clements site............. 121

120. Clements Brushed olla (Vessel No. 105b) in Burial H-15 at the Clements site. . . . . . . . . . 122

121. Mockingbird Punctated jar (Vessel No. 177) in Burial H-18 at the Clements site . .......... 123

122. Simms Engraved carinated bowl (Vessel No. 191) in Burial H-19 at the Clements site. . . . . . . . 124

123. Incised-appliqued jar (Vessel No. 204a) from Burial H-21 at the Clements site. . . . . . . . . . . 125

124. Simms Engraved carinated bowl (Vessel No. 215) in Burial H-22 at the Clements site . . . . . . . . 127 
125. Plain body and base of a carinated bowl (Vessel No. X-1), unknown context

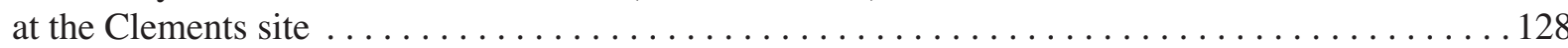

126. Simms Engraved carinated bowl (Vessel No. X-2) in unknown context at the Clements site . . . . 129

127. Simms Engraved carinated bowl (Vessel No. X-3) in unknown context at the Clements site ......130

128. Engraved carinated bowl (Vessel No. X-4) in unknown context at the Clements site ..........131

129. Engraved bottle (Vessel No. X-5) in unknown context at the Clements site . . . . . . . . . 132

130. Foster Trailed-Incised, var. unspecified jar (Vessel No. X-6) in an unknown context

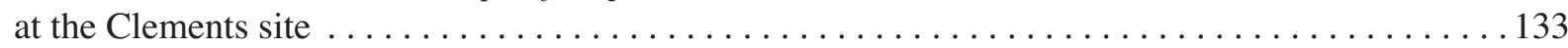

131. Pinched-brushed jar (Vessel No. X-7) in unknown context at the Clements site . . . . . . . . . 134

132. Engraved compound bowl (Vessel No. X-8) in unknown context from the Clements site . . . . . . 135

133. Engraved fine ware compound bowl (Vessel No. X-9) in unknown context at the Clements site . . 136

134. Emory Punctated-Incised jar (Vessel No. X-11) in unknown context at the Clements site........ 137

135. Ancestral Caddo sites with ceramic vessel assemblages mentioned in the text; the Clements and Goode Hunt sites are only a few miles apart. . . . . . . . . . . . . . . 143 


\section{List of Tables}

1. Information on the size, depth, and orientation of the Goode Hunt site burials $\ldots \ldots \ldots \ldots \ldots$

2. Funerary objects from the Goode Hunt site, Cass County, Texas, recovered in 1932

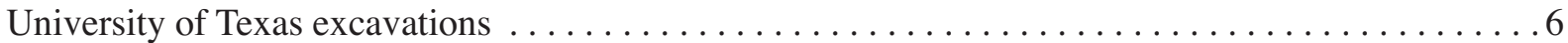

3. Information on the size, depth, and orientation of the Clements site burials . . . . . . . . 92

4. Funerary objects at the Clements site, Cass County, Texas recovered in 1932 University

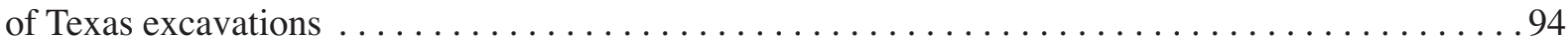

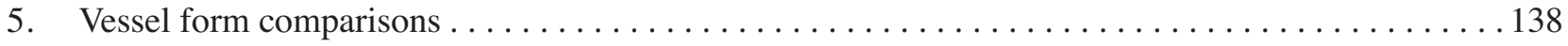

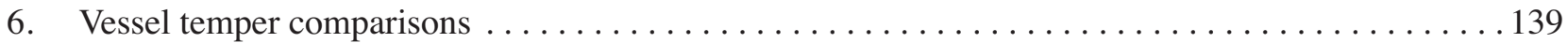

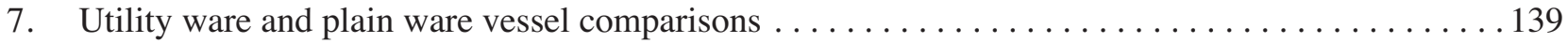

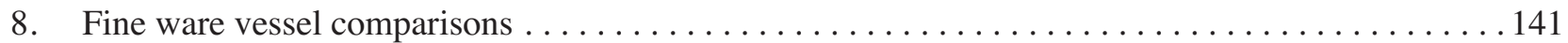

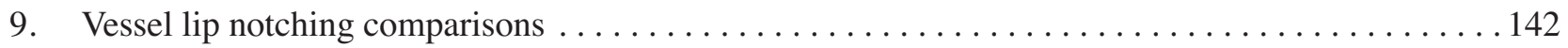

10. Late Caddo and early historic Caddo period mortuary vessel assemblages, including

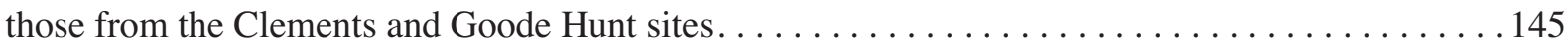




\section{Acknowledgments}

I appreciate the access provided by the Caddo Nation of Oklahoma and the staff at the Texas Archeological Research Laboratory at The University of Texas at Austin, in particular Marybeth Tomka, to the records and vessel collections from the Goode Hunt and Clements sites. Bo Nelson took the excellent vessel photographs, and Sandy Hannum and Lance Trask prepared other figures and maps included in this monograph. 


\section{Introduction}

The Goode Hunt (41CS23) and Clements (41CS25) sites are early historic Nasoni Caddo cemeteries and settlements in the Pineywoods of East Texas (Figure 1). The Clements site was first investigated in 1898 by W. T. Scott (Perttula et al. 2010), and then again in 1932 by archaeologists from the University of Texas (UT) (Jackson 1932a). The nearby Goode Hunt site was also investigated by UT in 1932 (Jackson 1932b).

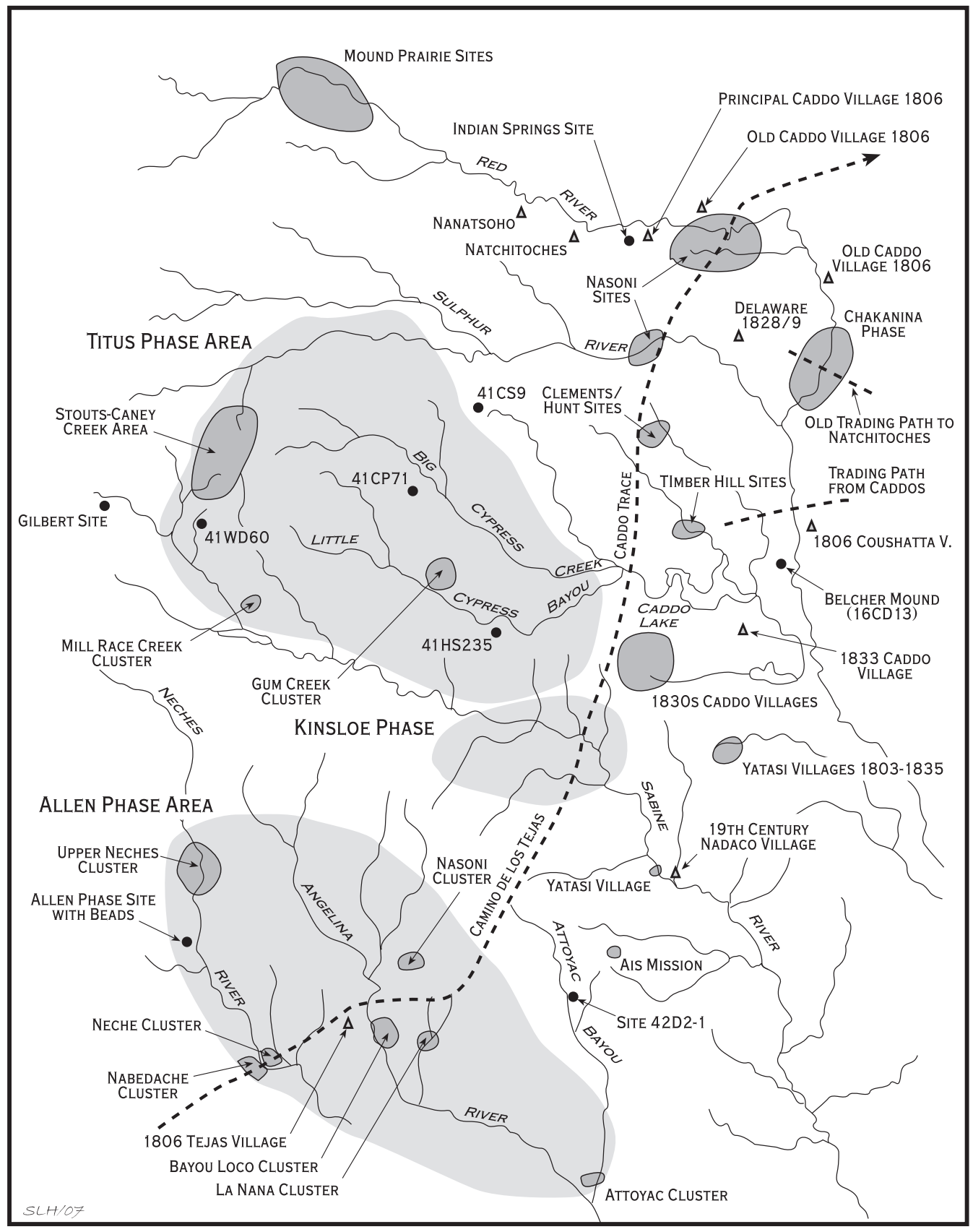

Figure 1. The location of the Goode Hunt and Clements sites in East Texas, and the location of other historic Caddo sites and phases. 
In this publication, the concern is with the 153 Caddo ceramic vessels recovered from burial features at the two sites during these various investigations, including the 34 vessels from the Clements site being curated by the American Museum of Natural History (Perttula et al. 2010), the remainder in the collections of the Texas Archeological Research Laboratory at The University of Texas at Austin (TARL), and the seven vessels from the Clements site in the Dickinson collection (Dickinson 1941). The ceramic vessels from the two sites provide the most complete picture of the character of Nasoni Caddo ceramic assemblages from funerary contexts at the time of first contacts with Europeans beginning in the late 17th century. 


\section{Goode Hunt Site (41CS23)}

The Goode Hunt site (41CS23), which lies about 5 miles to the west of the Clements site (41CS25) (see below) and 8 miles west of Atlanta, Texas, is an early historic Nasoni Caddo settlement on an elongated and wooded alluvial knoll east of Kite Creek (Figure 2; see also Jackson 1932b; Perttula 1992). It was near or on the Caddo Trace (see Foster 1998:320). Two other probable Nasoni Caddo cemeteries of similar kind and age in the vicinity include the A. P. Fourche and R. A. Simpson farm sites on Black Bayou and Black Cypress Bayou, but these sites are poorly known. These other cemeteries had ancestral Caddo burials accompanied by glass trade beads, large well-made chert bifaces or knives, and numerous aboriginal ceramic vessels (Perttula 1993).

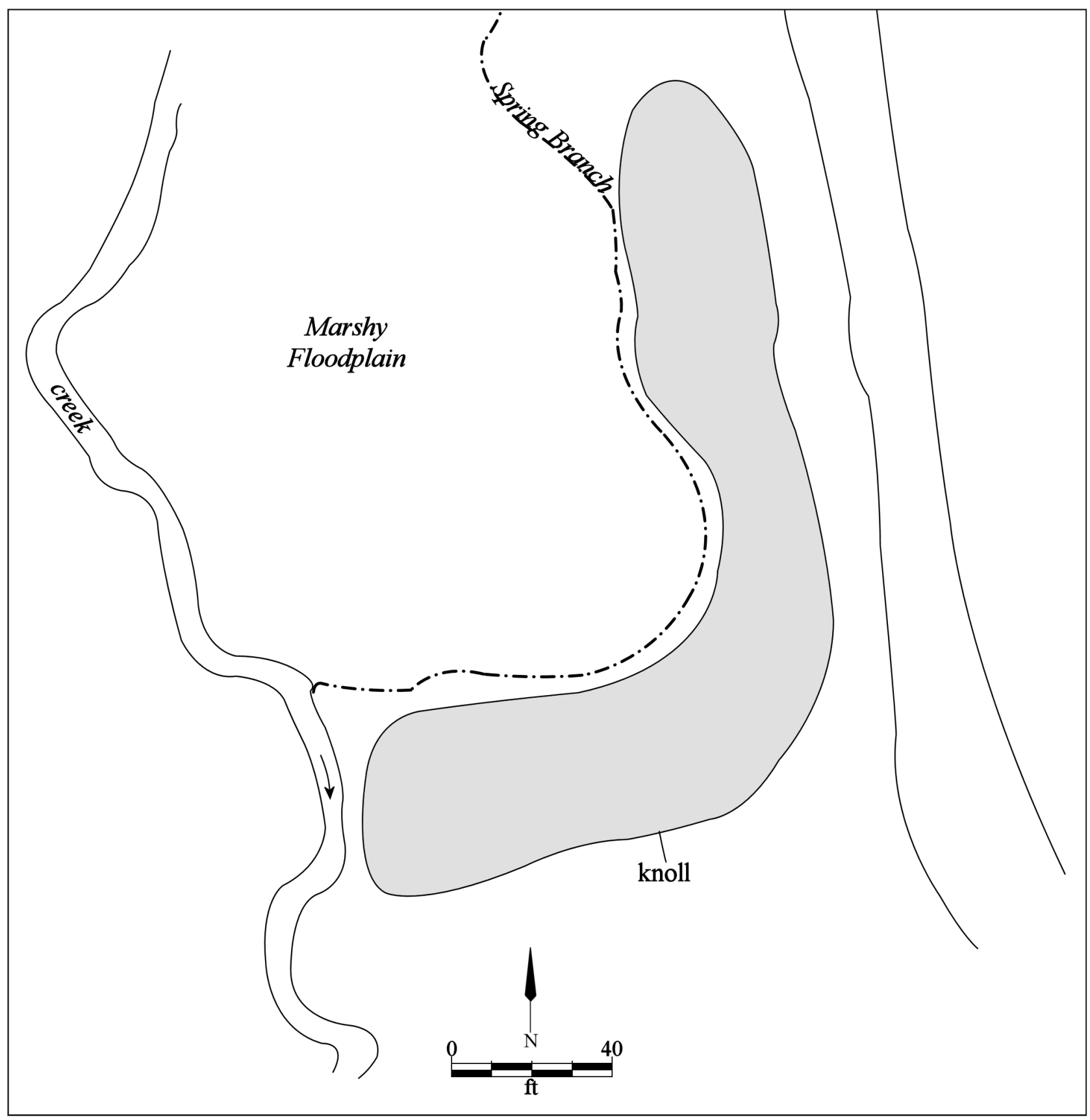

Figure 2. Map of the Goode Hunt site and vicinity (from Jackson 1932b:47). 


\section{Excavations and Burial Features}

University of Texas (UT) archaeologists excavated the Goode Hunt site from July 11, 1932 to August 1, 1932, with A. T. Jackson as the Field Foreman. According to Jackson (1932b:1), the site had first been found about 1917 by a local farmer that had discovered a burial and pottery vessels when plowing the land. The Sheriff of Cass County and a Mr. Oscar Webster of Atlanta, Texas, had removed the skeleton and the pottery vessels at that time. What happened to these materials, or how UT archaeologists found out about the Goode Hunt site is not known.

The UT excavations identified 17 ancestral Caddo burials in two or three roughly northeast-southwest-oriented rows in a large area on the knoll opened by wide-spread and eventually contiguous shovel trenching (Figure 3). The excavations also encountered a single dog burial west of Burial I-2, as well as a single isolated ceramic vessel east of Burial I-11.

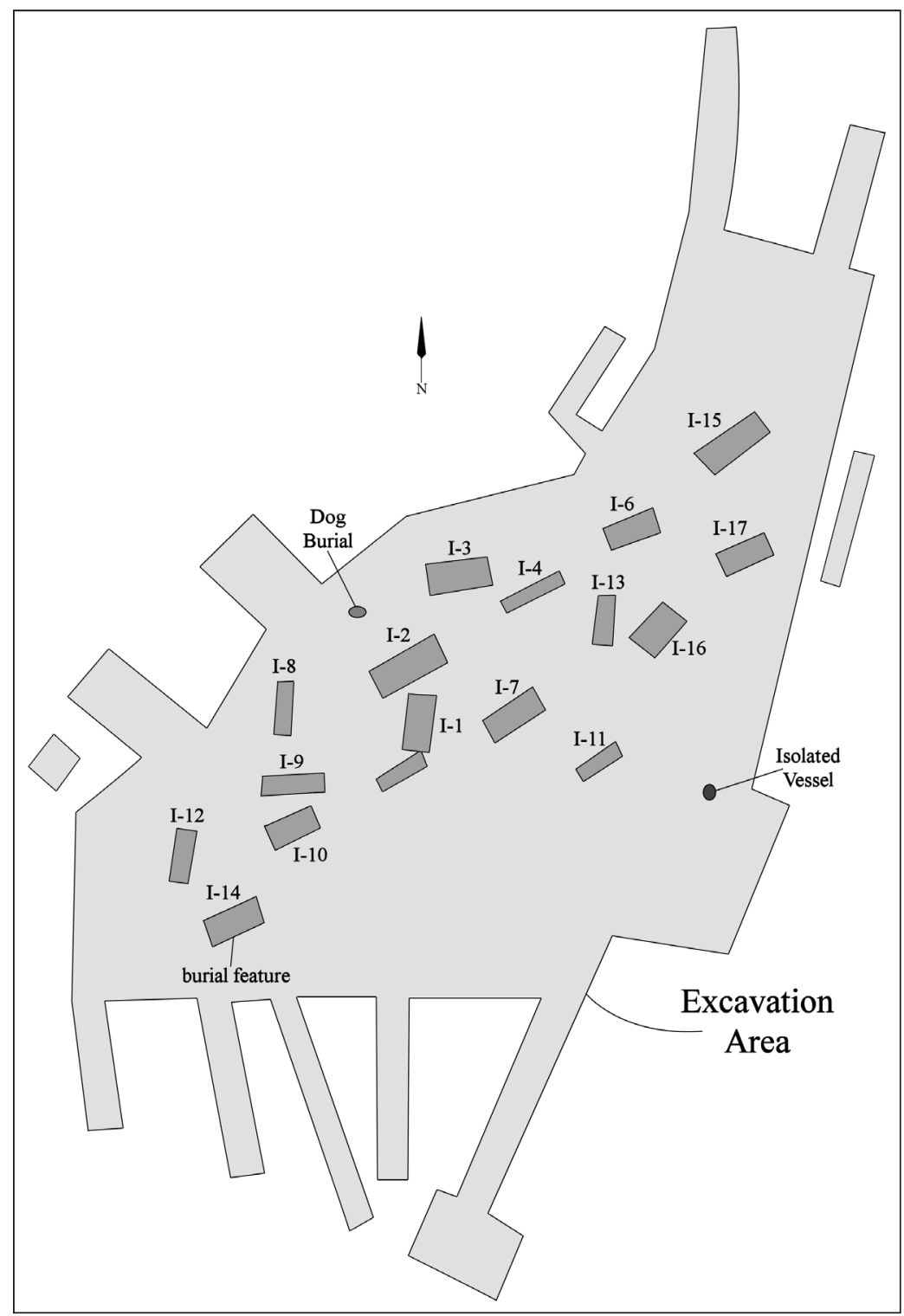

Figure 3. 1932 excavations at the Goode Hunt site and the location of ancestral Caddo burial features, a dog burial, and a single isolated ceramic vessel (after Jackson 1932b:46). 
Each of the Caddo burials in the Goode Hunt cemetery were placed in graves on their back, in an extended supine position. The graves ranged from an estimated 4.5-8.0 ft. in length and 1.7-3.8 ft. in width (Table 1). The graves were relatively shallow, ranging from only 0.6-2.4 ft. in depth. Of the 17 burials in the cemetery, 15 are apparently those of adult Caddo men and women, one may be an adolescent (Burial I-11), and only one burial (Burial I-5) in the central part of the cemetery was that of a child.

Table 1. Information on the size, depth, and orientation of the Goode Hunt site burials.

\begin{tabular}{lccccl}
\hline Burial \# & $\begin{array}{c}\text { Length } \\
(\mathrm{ft} .)\end{array}$ & $\begin{array}{c}\text { Width } \\
(\mathrm{ft} .)\end{array}$ & $\begin{array}{c}\text { Depth } \\
\text { (ft.) }\end{array}$ & $\begin{array}{c}\text { Orientation } \\
\text { (degrees) }\end{array}$ & $\begin{array}{l}\text { Head Position } \\
\text { in the grave; age and sex }\end{array}$ \\
\hline I-1 & 6.4 & 3.0 & 2.0 & 0 & facing N; adult, IND \\
I-2 & 8.0 & 3.8 & 2.2 & 35 & facing SW; adult, IND \\
I-3 & 6.0 & 2.8 & 2.4 & 15 & facing SW; IND, IND \\
I-4 & 7.0 & 1.7 & 1.9 & 35 & facing SW; adult, IND \\
I-5 & 5.2 & 1.8 & 1.5 & 40 & facing SW; child, est. \\
& & & & & 6-8 years old \\
I-6 & 5.8 & 2.5 & 1.9 & 25 & facing SW; adult, IND \\
I-7 & 5.9 & 2.5 & 2.2 & 40 & facing SW; adult, IND \\
I-8 & 5.8 & 1.8 & 1.7 & 5 & facing N; adult, IND \\
I-9 & 6.8 & 2.0 & 1.0 & 10 & facing SW; adult, IND \\
I-10 & 4.5 & 2.3 & 0.6 & 35 & facing SW; IND, IND \\
I-11 & 5.2 & 1.7 & 0.9 & 40 & facing SW; adolescent, IND \\
I-12 & 5.8 & 2.5 & 1.8 & 5 & facing N; adult, IND \\
I-13 & 4.6 & 1.8 & 2.3 & 180 & facing N; adult, IND \\
I-14 & 6.3 & 3.0 & 1.3 & 30 & facing SW; adult, IND \\
I-15 & 7.5 & 2.8 & 2.3 & 30 & facing SW; adult, IND \\
I-16 & 4.8 & 3.5 & 1.5 & 25 & facing SW; adult, IND \\
I-17 & IND & 1.6 & 1.8 & 25 & facing SW; adult, IND \\
\end{tabular}

$\mathrm{N}=$ north; $\mathrm{SW}=$ southwest; IND=indeterminate

The burials in the cemetery were oriented in several directions, with the heads of most of the deceased ( $n=13,76$ percent) facing to the southwest-west (see Table 1). The remaining four burials (24 percent) had their heads facing to the north. The Caddo burials at the Clements site were also mainly placed in graves with their heads facing to the southwest-west.

The principal funerary offering in the ancestral Caddo burials from the Goode Hunt site is ceramic vessels of varying form and decorative motifs/elements (Table 2). According to Jackson (1932b), the 17 graves had 78 ceramic vessels as funerary offerings, with a mean of 4.6 vessels per grave and a range of one to nine vessels. One burial had a ceramic elbow pipe, and seven of the burials had either chipped or ground stone tools. Five burials had mussel shell hoes, and another (Burial I-10) had a mussel shell valve placed inside one of the ceramic vessels. Burial I-15 had a deer mandible in the grave. Five of the Goode Hunt burials had pigment offerings (gray, green, and red). Jackson (1932b:23) suggests that the red ochre used to make the red clay pigment came from "Paint Hill" about 2 miles southeast of the Goode Hunt site. Burial I-7 had a thin piece of metal placed in the grave above the head of the deceased. 
Table 2. Funerary objects from the Goode Hunt site, Cass County, Texas, recovered in 1932 University of Texas excavations.

\begin{tabular}{|c|c|c|c|c|c|c|c|c|}
\hline $\begin{array}{l}\text { Burial } \\
\text { No. }\end{array}$ & $\begin{array}{l}\text { Ceramic } \\
\text { Vessels }\end{array}$ & $\begin{array}{c}\text { Ceramic } \\
\text { Pipes }\end{array}$ & $\begin{array}{l}\text { Shell } \\
\text { Beads }\end{array}$ & $\begin{array}{l}\text { Shell } \\
\text { Disc }\end{array}$ & $\begin{array}{c}\text { Shell } \\
\text { Pendants }\end{array}$ & $\begin{array}{l}\text { Stone } \\
\text { Tools }\end{array}$ & $\begin{array}{l}\text { Bone/Shell } \\
\text { Tools }\end{array}$ & Other \\
\hline $\mathrm{I}-1$ & 1 & 1 & - & - & - & 1 & - & - \\
\hline $\mathrm{I}-2$ & 6 & - & - & - & - & 1 & - & - \\
\hline I-3 & 6 & - & - & - & - & 1 & $1 \mathrm{MS}$ hoe & \\
\hline $\mathrm{I}-4$ & 5 & - & - & - & - & - & - & gray pigment \\
\hline I-5 & 8 & - & - & - & - & - & - & $\begin{array}{l}\text { gray pigment; } \\
\text { red pigment }\end{array}$ \\
\hline I-6 & 3 & - & - & - & - & 3 & $1 \mathrm{MS}$ hoe & - \\
\hline $\mathrm{I}-7$ & 5 & - & - & - & - & - & - & $\begin{array}{l}\text { gray pigment; } \\
\text { thin piece of } \\
\text { metal }\end{array}$ \\
\hline $\mathrm{I}-8$ & 2 & - & - & - & - & - & - & - \\
\hline I-9 & 5 & - & - & - & - & - & $1 \mathrm{MS}$ hoe & - \\
\hline $\mathrm{I}-10$ & 2 & - & - & - & - & - & - & MS in vessel \\
\hline $\mathrm{I}-11$ & 3 & - & - & - & - & - & - & - \\
\hline $\mathrm{I}-12$ & 2 & - & - & - & - & - & - & - \\
\hline $\mathrm{I}-13$ & 1 & - & - & - & - & - & - & - \\
\hline I-14 & 9 & - & - & - & - & - & $1 \mathrm{MS}$ hoe & - \\
\hline $\mathrm{I}-15$ & 9 & - & - & - & - & 1 & - & $\begin{array}{l}\text { deer mandible; } \\
\text { green pigment }\end{array}$ \\
\hline $\mathrm{I}-16$ & 8 & - & - & - & - & 3 & $1 \mathrm{MS}$ hoe & pigment \\
\hline $\mathrm{I}-17$ & 3 & - & - & - & - & 2 & - & - \\
\hline Total & $78 *$ & 1 & - & - & - & 12 & 5 & 9 \\
\hline
\end{tabular}

*a number of the vessels were not located in the TARL vessel collections when the collection was documented in February 2015; see discussion below in descriptions of the different burials at the site MS=mussel shell

Where the Goode Hunt site funerary offerings differ from those placed in the Clements site graves is the absence of shell beads, shell discs, and shell pendants, as well as glass beads (see Table 2). The absence of glass beads in the Goode Hunt burials suggests that these burials are slightly older than those from the Clements site, although many of the ceramic vessels in both cemeteries share stylistic motifs and vessel forms, especially the fine ware vessels.

The dog burial, marked by a mandible with teeth in place (Jackson 1932b:15), was ca. $3 \mathrm{~m}$ west of Burial I-2 (see Figure 3). It was lying at a depth of ca. $48 \mathrm{~cm}$ bs, and a small engraved compound bowl (Vessel No. 38) was ca. $8 \mathrm{~cm}$ from the mandible and a few other fragments of animal bone.

Burial I-1 is situated near the center of the cemetery (see Figure 3), and is an interment of an adult of "advanced age" (Jackson 1932b:4), based on the observed wear on the teeth. A single ceramic bottle of the Hatchel Engraved type had been placed between the legs (Figure 4), and an undecorated elbow pipe (Figure 5) was placed under the chin and near the right shoulder. Portions of a large chipped stone tool was resting near the right foot. 


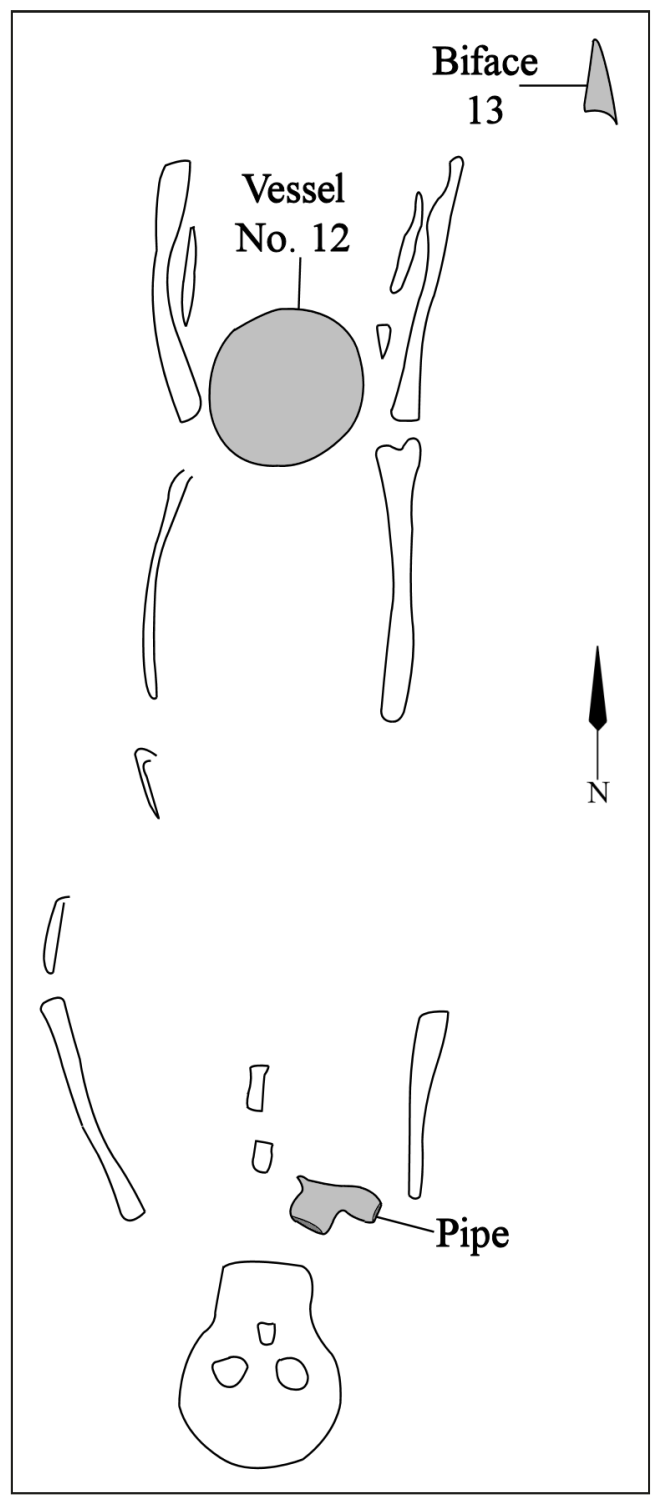

Figure 4. Burial I-1 at the Goode Hunt site.

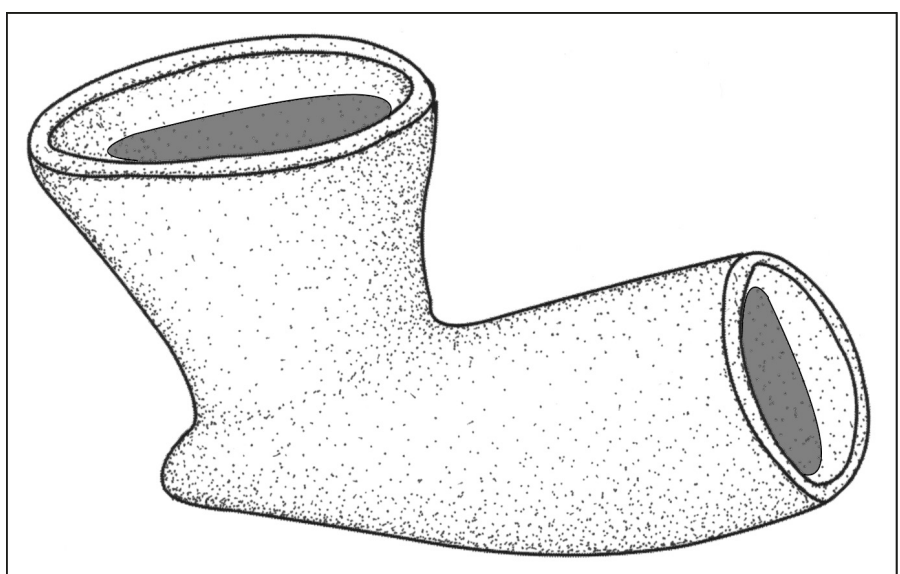

Figure 5. Ceramic elbow pipe (No. 11) in Burial I-1 at the Goode Hunt site. 
Burial I-2 had a number of ceramic vessels placed as funerary offerings near and above the head of the deceased, along with a ground stone tool (No. 20), as well as along the lower right and left leg and feet (Figure 6). A Hodges Engraved bottle (Vessel No. 14) was by the head, and above and to the right of the head was a Simms Engraved carinated bowl (Vessel No. 15) and a broken Foster Trailed-Incised, var. Moore jar (Vessel No. 16); a broken bowl (Vessel No. 17) by the left leg was not located in the TARL collections; sherds from this vessel were also found near Vessel No. 15 (Jackson 1932b:8). By the right leg was a Hodges Engraved carinated bowl (Vessel No. 18) and a very large Mockingbird Punctated jar (Vessel No. 19) was lying below the feet at the foot of the grave.

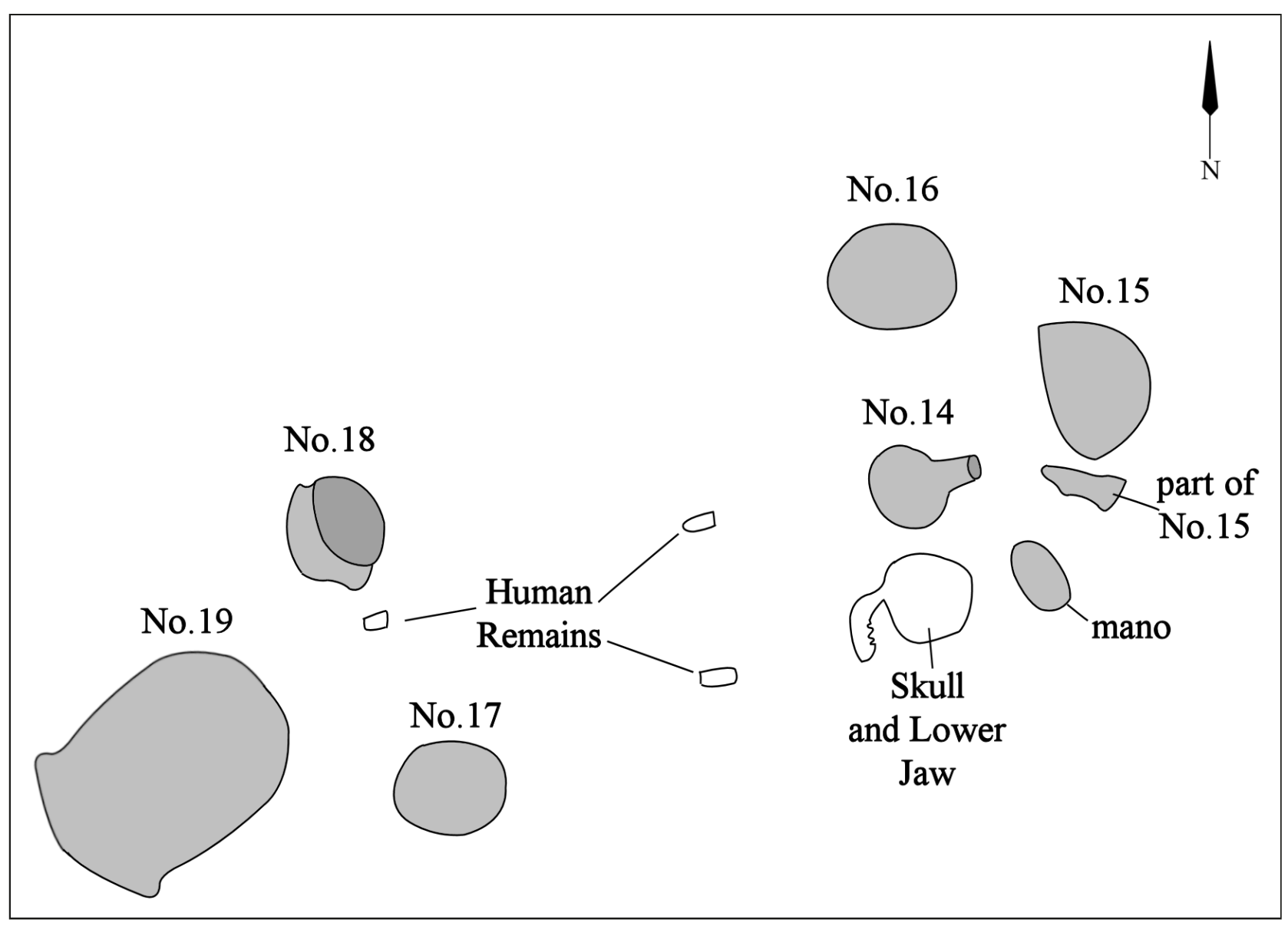

Figure 6. Burial I-2 at the Goode Hunt site.

In Burial I-3, a Hodges Engraved bottle (Vessel No. 21) had been placed by the back of the skull (Figure 7). To the left side of the skull with a Keno Trailed, var. Phillips bowl (Vessel No. 23) inside of a Taylor Engraved carinated bowl (Vessel No. 22). A ground stone tool was northeast of the skull. Two Simms Engraved carinated bowls (Vessel Nos. 24 and 25) were alongside the left knee and foot, and a large plain jar (Vessel No. 26) had been placed by the right foot. A mussel shell hoe was lying by the right hip (Figure 7).

Most of the funerary offerings in Burial I-4 were placed by and above the head of the deceased (Figure 8). This includes a Hodges Engraved bottle (Vessel No. 32) by the right side of the head, and an inverted Simms Engraved, var. Darco carinated bowl (Vessel No. 35) by the left side of the head. Two other small bowls (Vessels Nos. 33 and 34, not located in the TARL collections) were above the head, along with a small amount of gray clay pigment. A Simms Engraved carinated bowl (Vessel No. 36) was placed by the feet, along with a deer bone (Figure 8). 


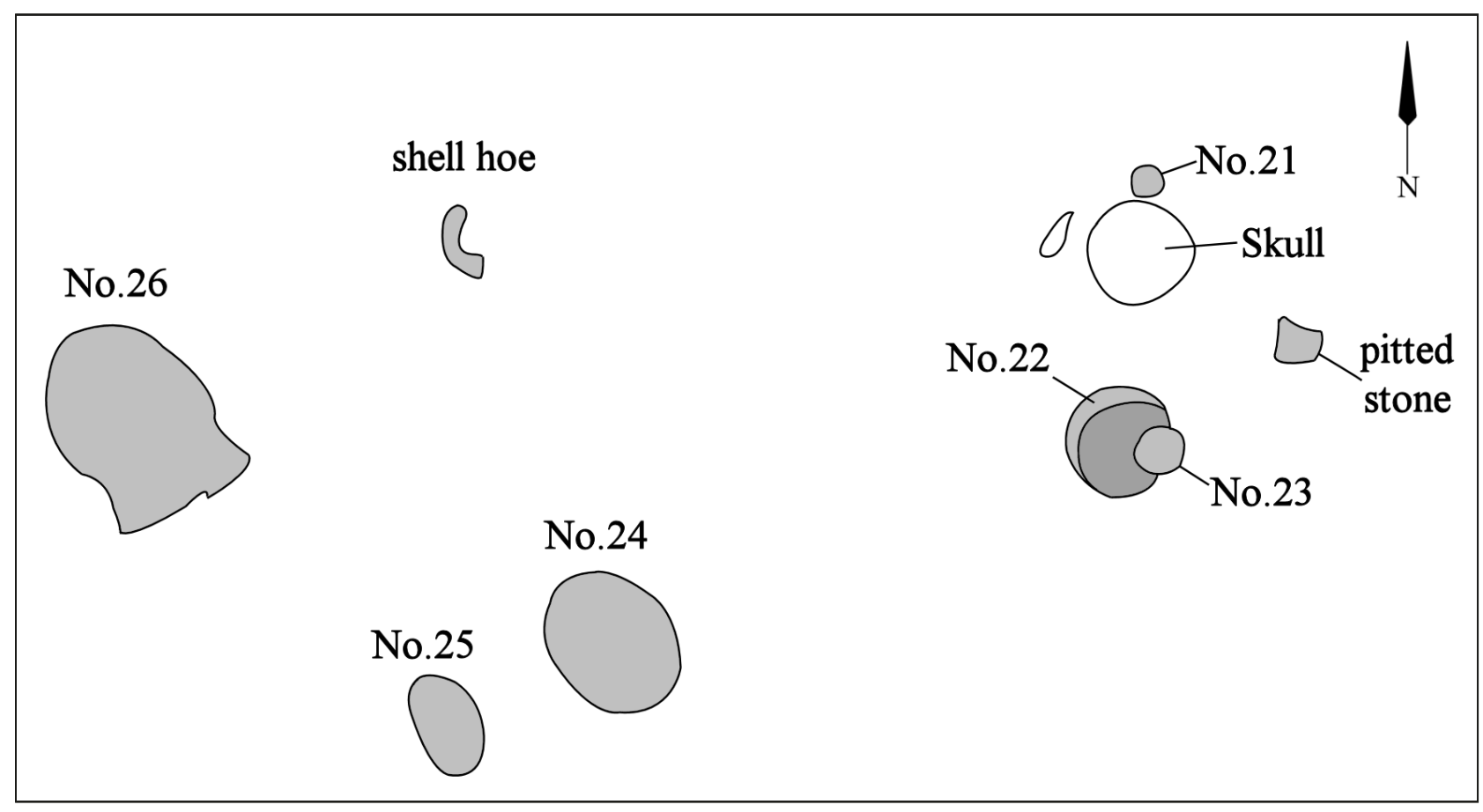

Figure 7. Burial I-3 at the Goode Hunt site.

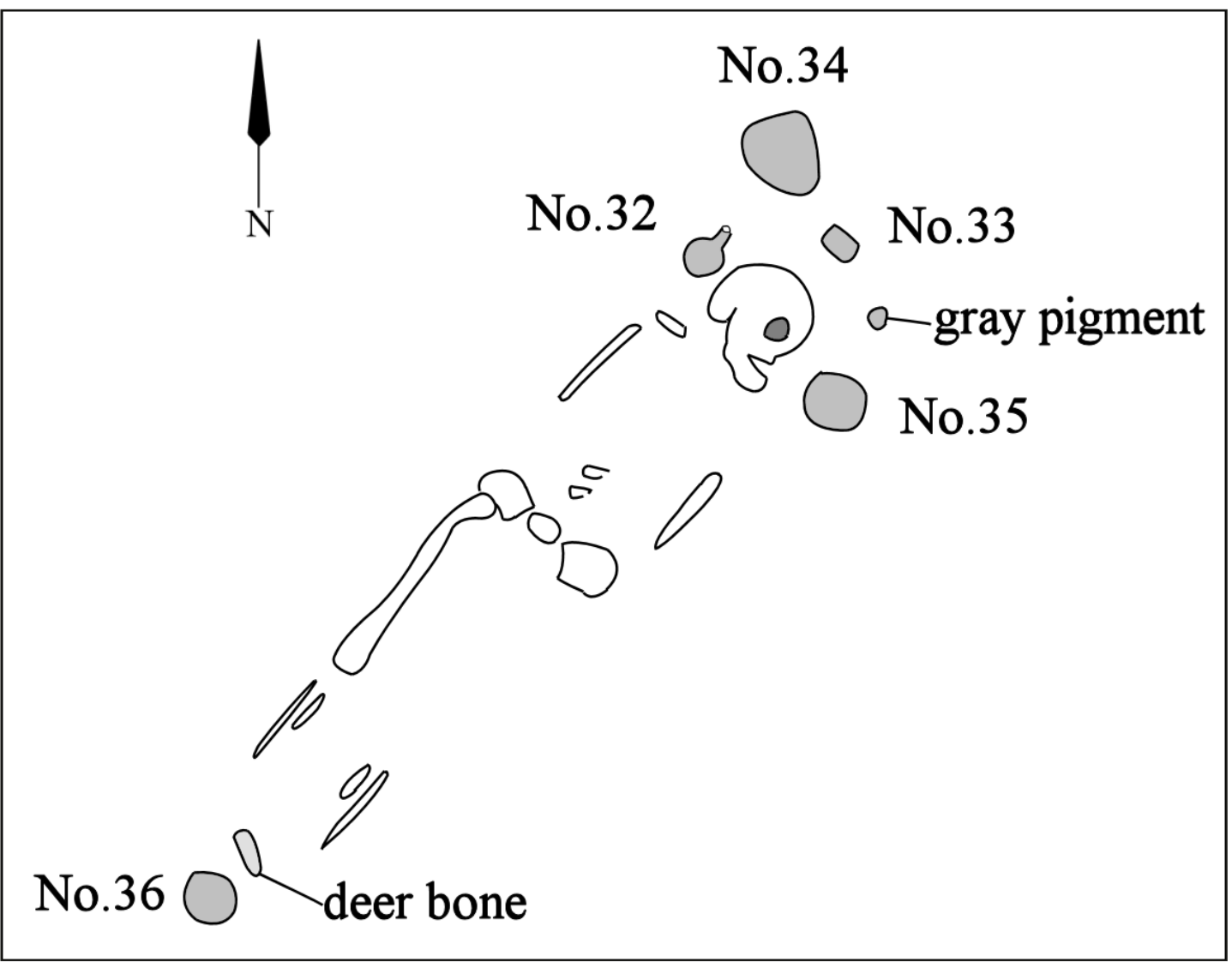

Figure 8. Burial I-4 at the Goode Hunt site. 
Burial I-5 is that of a child; the only preserved remains were parts of the jaw and teeth and fragments of the right femur (Jackson 1932b:15). The ceramic vessel funerary offerings include a miniature bottle (Vessel No. 40, not located in the TARL collections) to the left of the head, a Simms Engraved carinated bowl (Vessel No. 41), to the left of the jaw, and a cf. Pease Brushed-Incised jar (Vessel No. 42) by the left upper body (Figure 9). There are four Simms Engraved carinated bowls (Vessel Nos. 43-46) along the lower legs, and a Foster Trailed-Incised, var. Moore jar by the feet (Figure 9). An offering of red clay pigment had been placed between the miniature bottle and a Simms Engraved vessel by the head, and another Simms Engraved vessel (No. 45) had gray pigment inside it (Jackson 1932b:16).

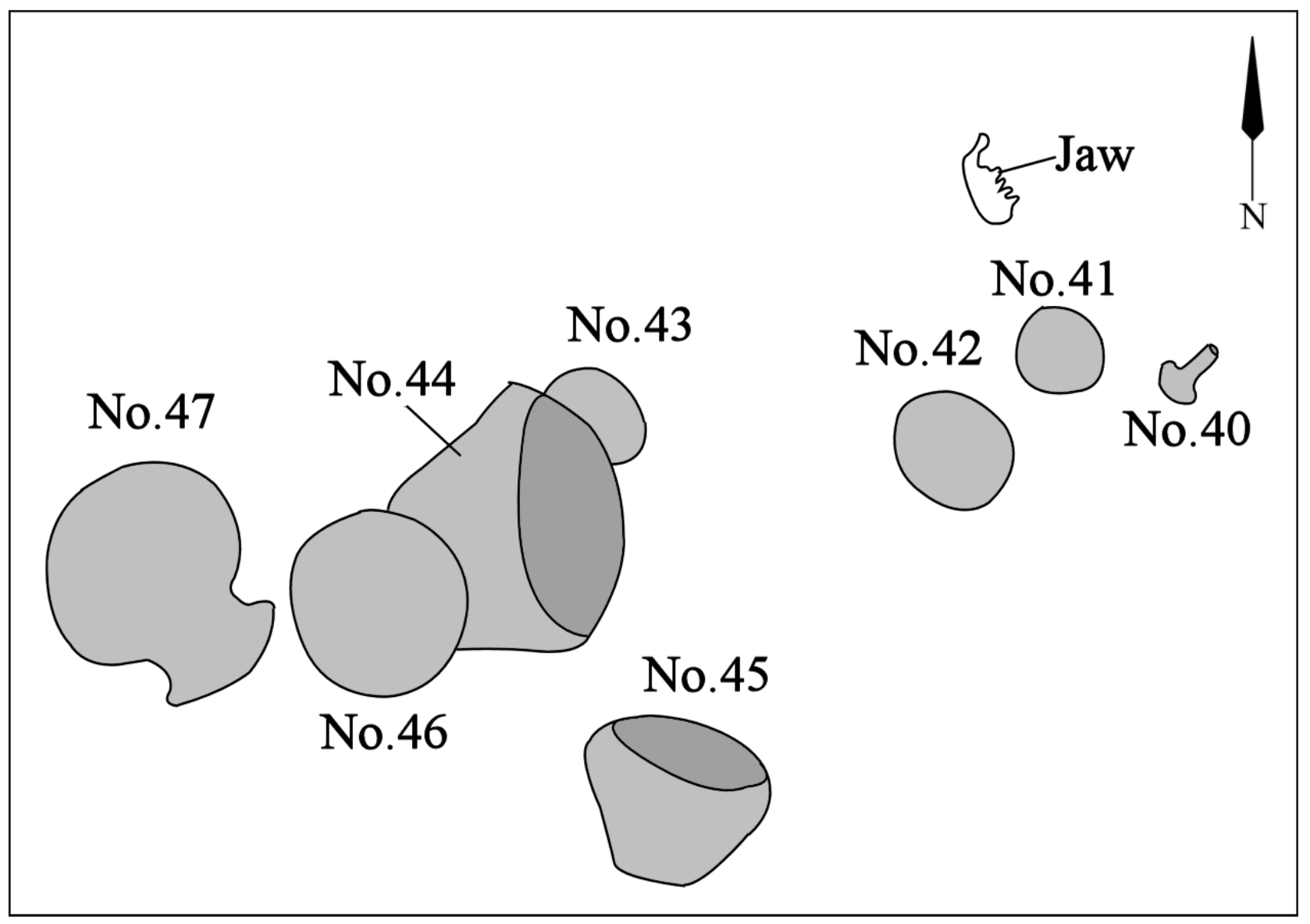

Figure 9. Burial I-5 at the Goode Hunt site.

In Burial I-6 at the Goode Hunt site, a small Bailey Engraved bottle (Vessel No. 50) had been placed by the right side of the head of the deceased, and a pitted stone (No. 53) lay nearby (Figure 10). There was an engraved bowl (Vessel No. 51) by the left side of the head, and a red-slipped Hodges Engraved deep bowl (Vessel No. 52) by the left knee. A second pitted stone (No. 54) rested by the right knee, and an abrader (No. 55) had been placed below the right foot. A broken mussel shell hoe was by the right foot (Figure 10).

The only evidence of European contact in the ancestral Caddo burials from the Goode Hunt site is a small, very thin, and oval-shaped "piece of sheet metal" (Jackson 1932b:21) above the head of the deceased and lying on the grave floor (Figure 11). Jackson's (1932:21) description of the piece - "one side of metal bright and slick; other side has a dull, rough finish. The thin edge will bend and crumble" - suggests it is a piece of brass or a cupreous piece, perhaps a kettle fragment. 


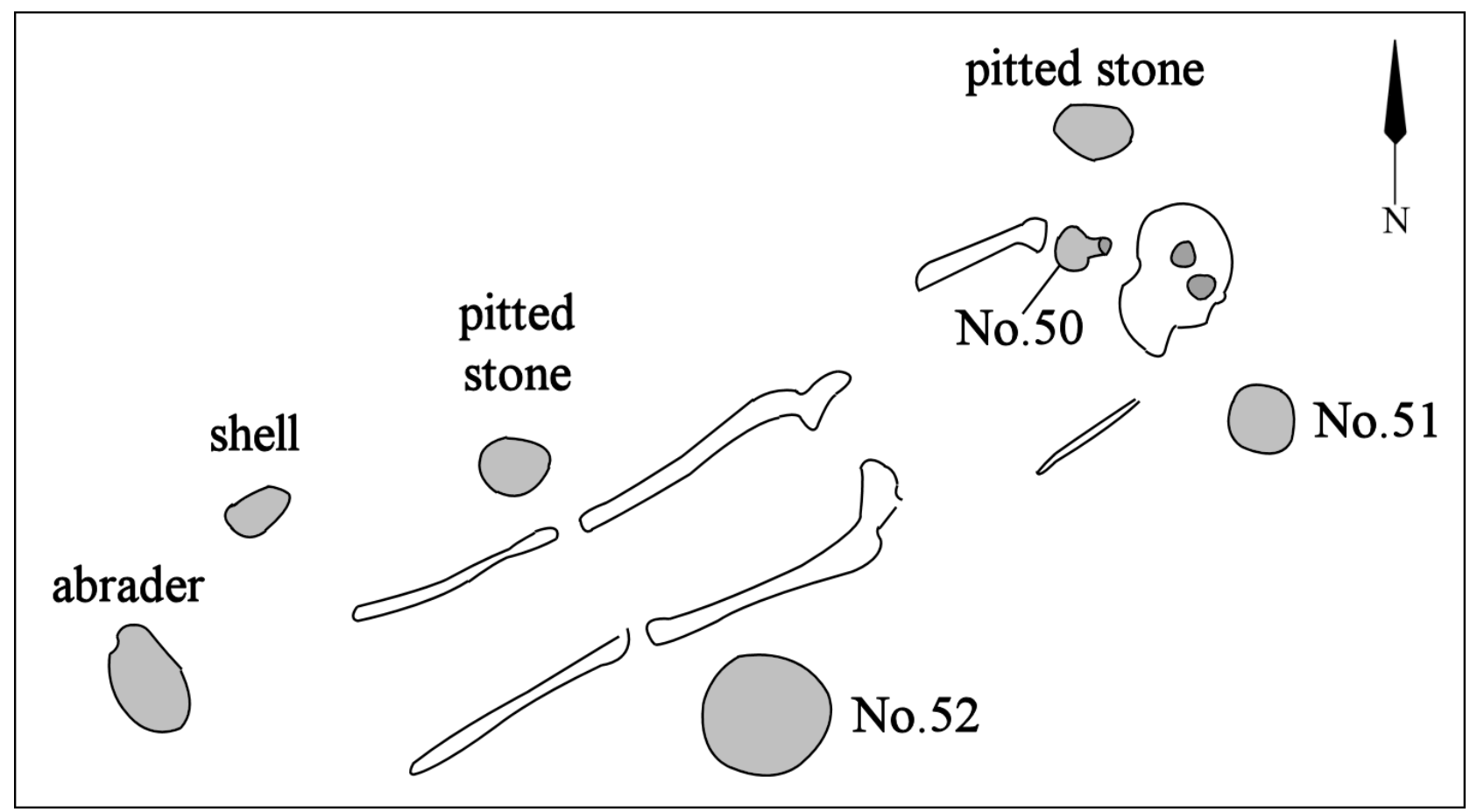

Figure 10. Burial I-6 at the Goode Hunt site.

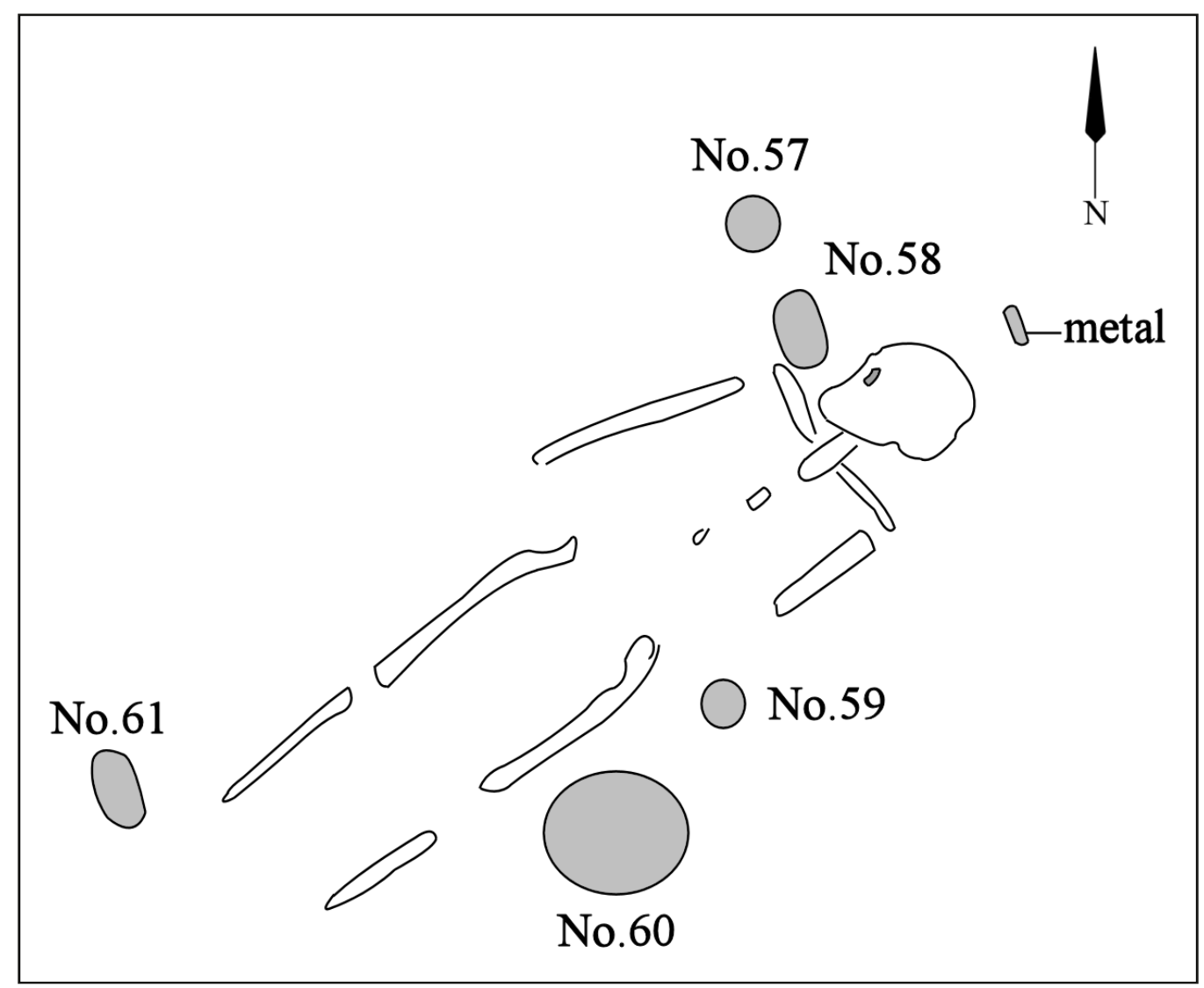

Figure 11. Burial I-7 at the Goode Hunt site. 
In addition to the piece of metal, a small Hodges Engraved bottle (Vessel No. 57, not located in the TARL collections) and a Simms Engraved carinated bowl (Vessel No. 58) were by the right side of the head (see Figure 11). Another Simms Engraved carinated bowl (Vessel No. 59) was placed by the left arm (this vessel contained a green clay pigment), and a broken Maydelle Incised jar (Vessel No. 60) was by the left leg. Another Simms Engraved vessel (Vessel No. 61, not located in the TARL collections) had been placed below the right foot (see Figure 11).

Burial I-8 had three funerary offerings, all ceramic vessels. Two broken jars (Vessel Nos. 63a, Karnack Brushed-Incised and 63b, a plain jar) were by the right hip, and an engraved carinated bowl (Vessel No. 64) had been placed by the right leg (Figure 12).

A Hodges Engraved bottle (Vessel No. 65) was resting along the right side of the skull of Burial I-9 at the Goode Hunt site (Figure 13). Other funerary offerings included a cf. Cabaness Engraved carinated bowl (Vessel No. 66) by the right knee, a small bowl (Vessel No. 67, not located in TARL collections) placed upside down by the upper right leg, a Mockingbird Punctated jar (Vessel No. 68) by the right foot, and a Maydelle Incised jar (Vessel No. 69) below the feet (Figure 13). A mussel shell hoe (No. 70) rested by the right foot, and an unmodified mussel shell had been placed by the left hip of the deceased.

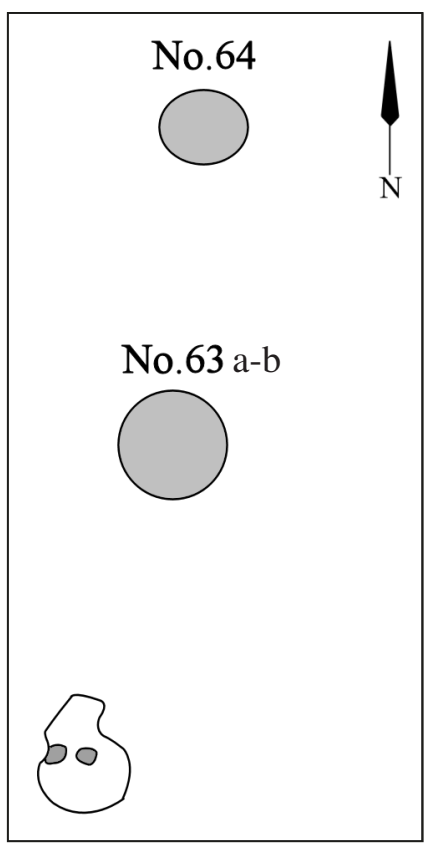

Figure 12. Burial I-8 at the Goode Hunt site.

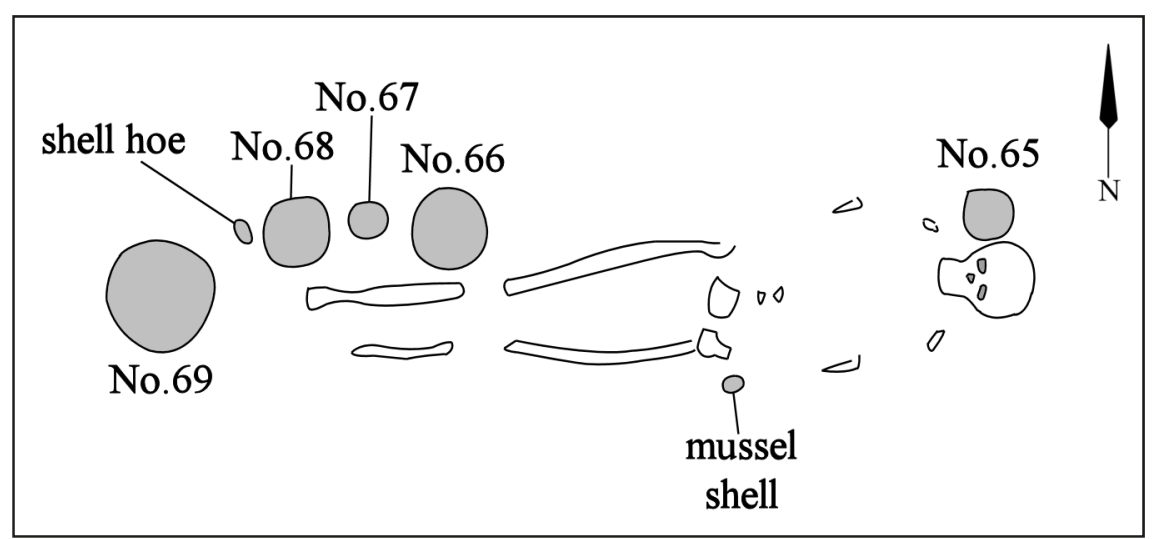

Figure 13. Burial I-9 at the Goode Hunt site.

All that remained of the deceased individual in Burial I-10 was a small section of one leg bone (Figure 14a). Funerary offerings included a plain four-legged bottle (Figure 14b, Vessel No. 74, not located in the TARL collections), perhaps near the head of the deceased, and a plain jar (Vessel No. 75), perhaps by the left leg, with a mussel shell valve inside it.

The funerary offerings placed with Burial I-11 comprised three ceramic vessels. This includes a brushed jar (Vessel No. 76) resting on the right side of the skull, a small cf. Keno Trailed bottle (Vessel No. 77) below the left side of the skull, and a cf. Simms Engraved carinated bowl (Vessel No. 78) on the left part of the pelvis (Figure 15).

Burial I-12 is one of only four Caddo burial at the Goode Hunt site where the body was buried with its head facing to the north, rather than to the southwest-west (Figure 16; see also Table 1). The other two are Burial I-1, I-8, and I-13 in the central and southern part of the cemetery (see Figure 3), and these burials likely comprise a separate burial grouping within the cemetery. Funerary offerings with Burial I-12 include a small engraved compound bowl with rim peaks (Vessel No. 79) resting on the left pelvis, and a small plain jar (Vessel No. 80) between the deceased's legs (Figure 16). 


\section{Section of

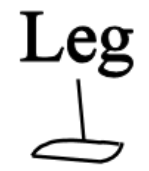

No.74
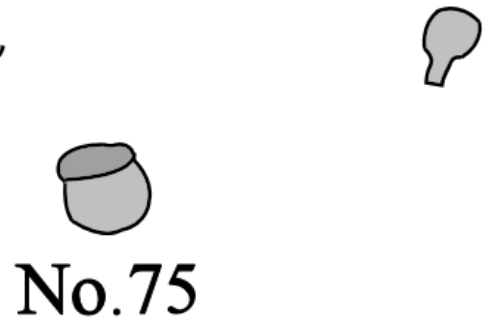

a

Figure 14. Burial I-10 at the Goode Hunt site: a, plan of the burial; b, drawing of Vessel No. 74 (after Jackson 1932b:28).

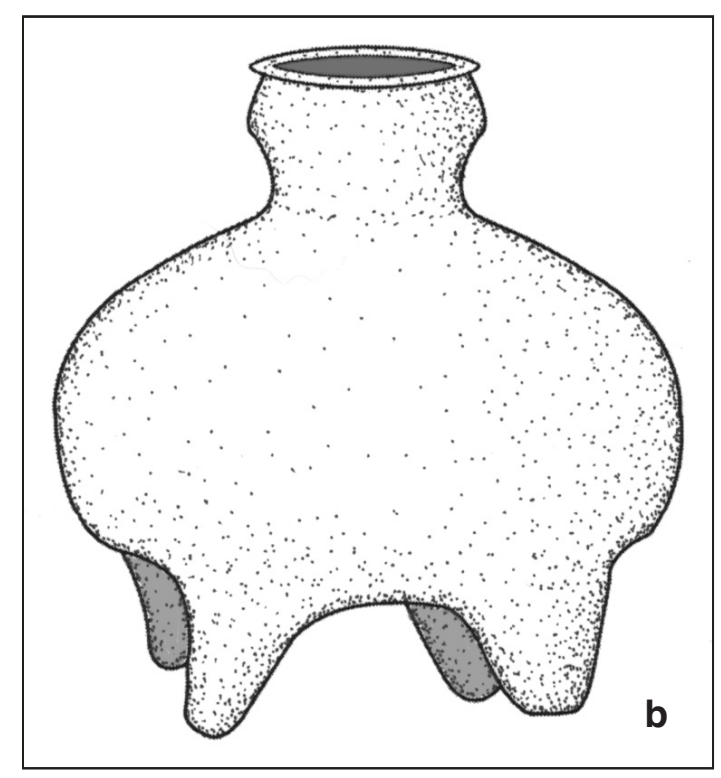

Burial I-13 was also buried with its head facing to the north (Figure 17). The single funerary offering was a crushed incised jar (Vessel No. 81) that had probably been placed at the foot of the grave.

There were a number of funerary offerings with Burial I-14 at the Goode Hunt site. A mussel shell hoe had been placed between the legs, and an unmodified mussel shell valve was below the feet (Figure 18). Above and to the left side of the head were three vessels, a plain shell-tempered jar (Vessel No. 87)

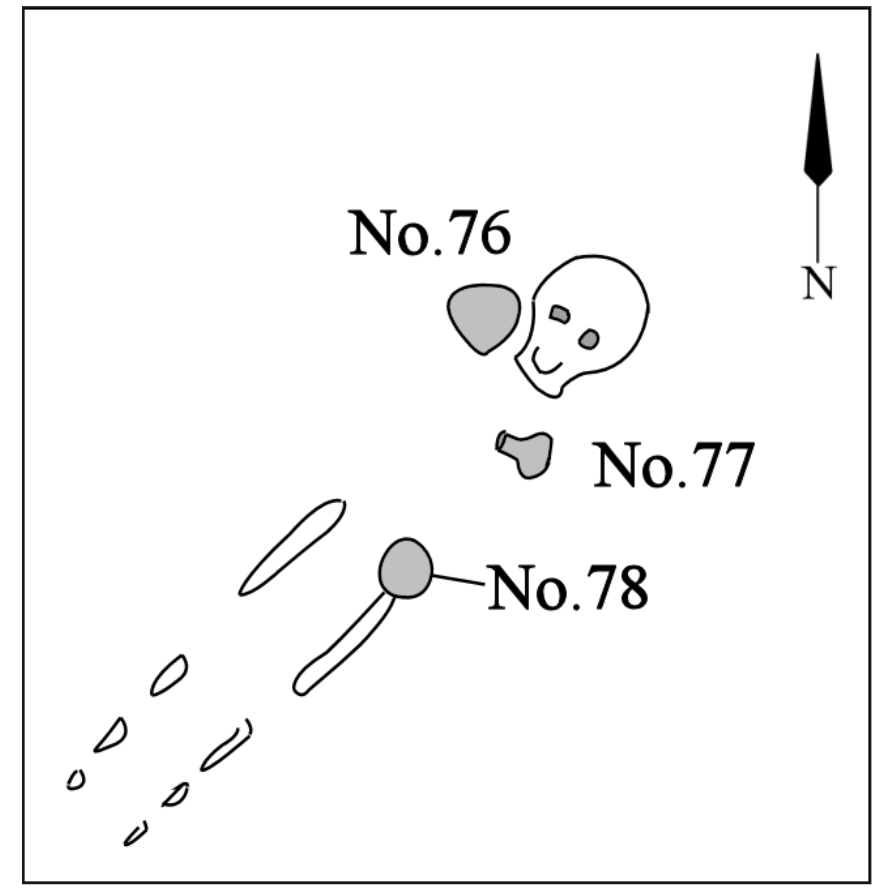

Figure 15. Burial I-11 at the Goode Hunt site.

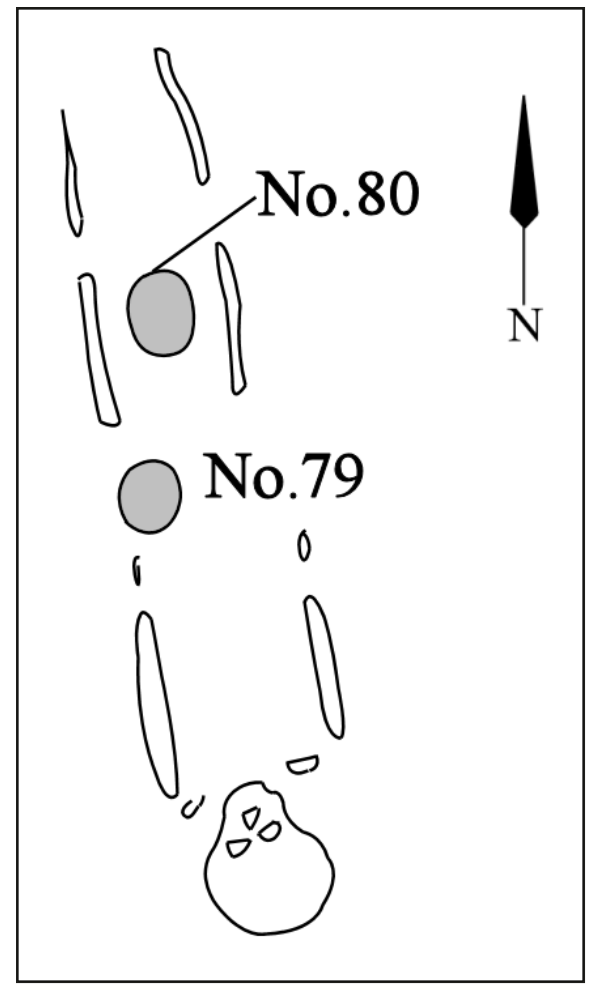

Figure 16. Burial I-12 at the Goode Hunt site. 
with a small incised jar (Vessel No. 86; it contained green clay pigment) within it, and a Keno Trailed, var. Phillips bowl (Vessel No. 85) partially overlying the small incised jar. To the right side of the head is a small bottle (Vessel No. 84, not located in the TARL vessel collections), a cf. Karnack Brushed-Incised jar (Vessel No. 82; it held a gray clay pigment), and an incised-punctated jar (Vessel No. 83) (Figure 18). Three other vessels had been placed by the feet, including a Simms Engraved carinated bowl (Vessel No. 88), a Taylor Engraved carinated bowl (Vessel No. 89), and an appliqued jar (Vessel No. 90).

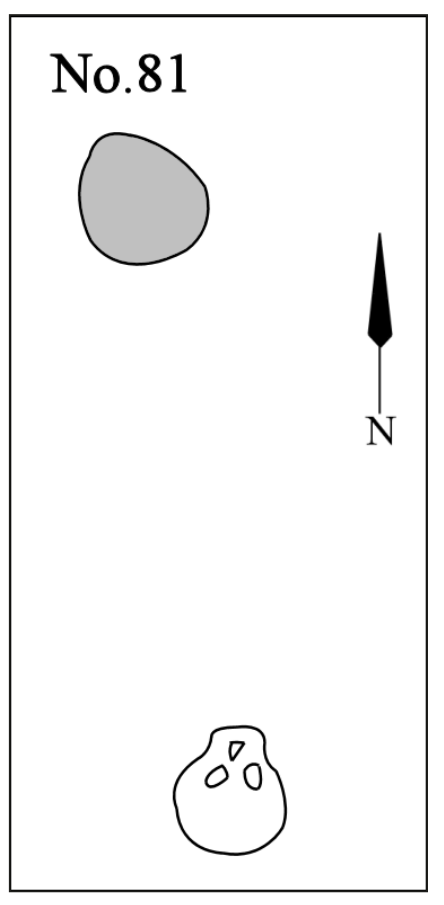

Figure 17. Burial I-13 at the Goode Hunt site.

Burial I-15 is the northernmost burial in the Goode Hunt cemetery (see Figure 3). Funerary offerings consist of nine ceramic vessels, a mussel shell valve by the left leg, a deer mandible above the skull, and a ferruginous sandstone "paint cup" (Jackson 1932b:37) with green clay pigment; this offering was to the side and below the left foot (Figure 19).

Two ceramic vessels were above and to the right or left of the head of the deceased. The vessel to the right of the head is a Simms Engraved carinated bowl (Vessel No.98), while the vessel to the left of the head is a Pease Brushed-Incised jar (Vessel No. 99); it held a gray clay pigment. A small Hodges Engraved bottle (Vessel No. 100) was by the left side of the skull (see Figure 19). A series of four vessels were placed along the right side of the body, beginning with a small engraved carinated bowl (Vessel No. 101), a Moore Noded bowl (Vessel No. 102), a

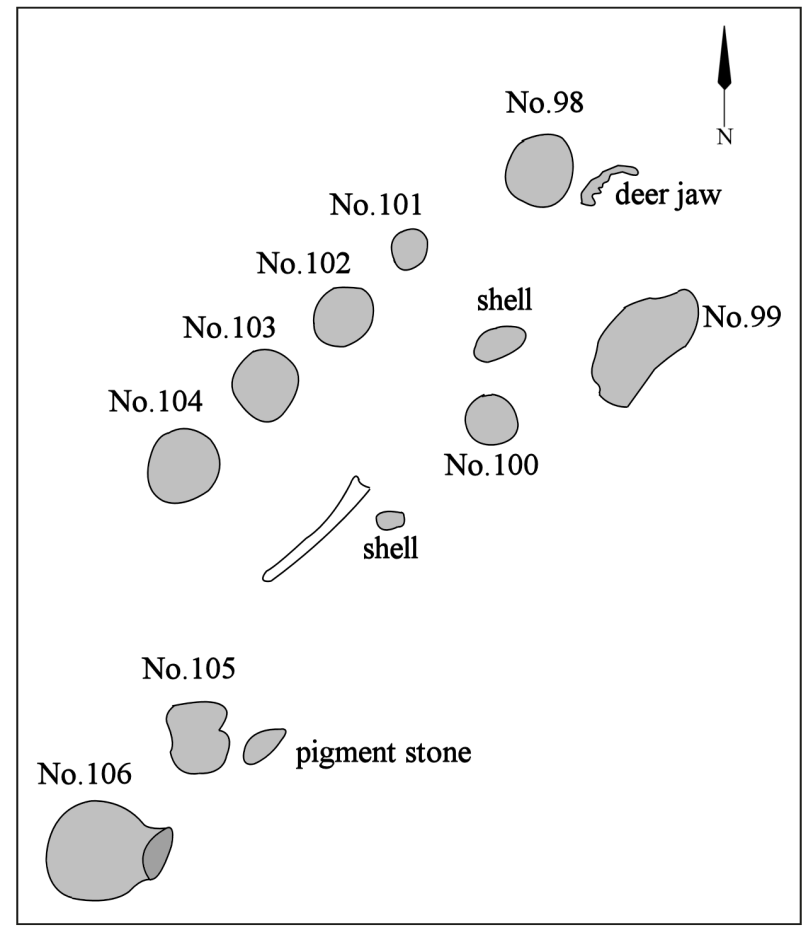

Figure 19. Burial I-15 at the Goode Hunt site. 


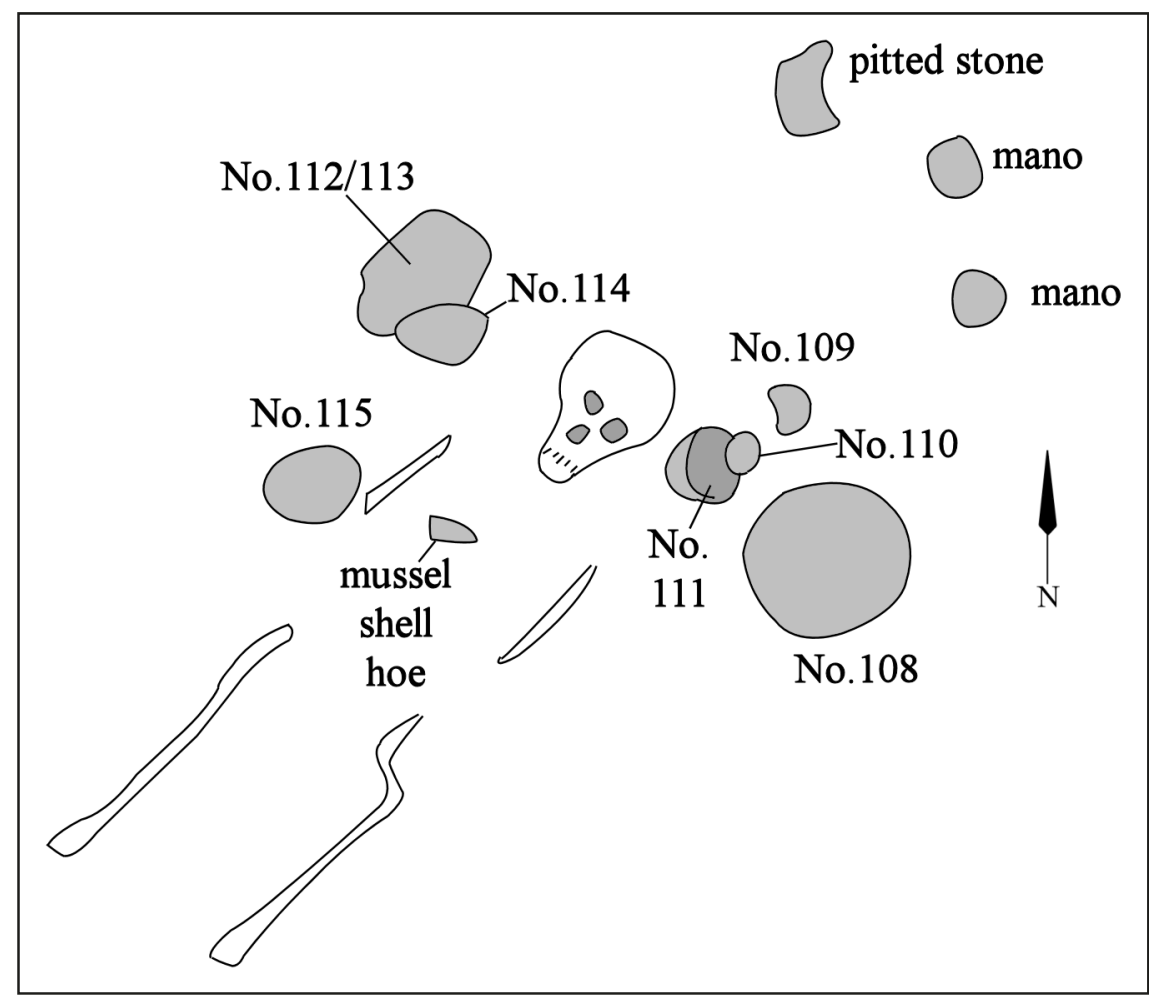

Figure 20. Burial I-16 at the Goode Hunt site.

bowl (Vessel No. 103, not located in the TARL vessel collections), and a plain jar (Vessel No. 104). Below the left foot were two brushed-appliqued jars (Vessel Nos. 105 and 106) (see Figure 19), as well as the ferruginous sandstone "paint cup" (No. 107) that held a green clay pigment.

Jackson (1932b:39) noted that the skull of Burial I-16 had two small holes (ca. $1 \mathrm{~cm}$ in diameter) in the forehead and at the top of the skull; he speculated that "these holes were made by buckshot wounds," which if that were the case would be confirmatory evidence that this burial dates to the early historic period. The skull should be examined by a bioarchaeologist to confirm or deny this possibility.

The majority of the funerary offerings with Burial I-16 were placed by or above the head of the deceased (Figure 20). This includes three vessels by the right side of the head: a Hudson Engraved deep bowl (Vessel No. 112), a cf. Pease Brushed-Incised jar (Vessel No. 113), and a small bowl (Vessel No. 114, not located in the TARL vessel collection). To the left side of the head were a cf. Hatchel Engraved bottle (Vessel No. 109), a Simms Engraved, var. Darco compound bowl (Vessel No. 110), and a Simms Engraved carinated bowl (Vessel No. 111) that held a clay pigment. A small jar (Vessel No. 115) had been placed by the lower right arm (Figure 20).

In addition to the ceramic vessels, there were three ground stone tools placed well above the head of the deceased in the grave of Burial I-16 as funerary offerings (see Figure 20). These included two manos (Nos. 117-118) and a pitted stone (No. 119). A mussel shell hoe (No. 116) had been placed on the right chest of the deceased.

Burial I-17 was located in the northern part of the Goode Hunt site cemetery (see Figure 3). A Hodges Engraved bottle (Vessel No. 121) was placed near the skull of the deceased, next to a Simms Engraved 
carinated bowl (Vessel No. 122) (Figure 21). Below the left side of the skull, perhaps in the shoulder area, was a brushed-incised-appliqued jar (Vessel No. 123) with deer teeth inside it (Jackson 1932b:41). Above and to the left of the head was a mano (No. 124) and two biface fragments.

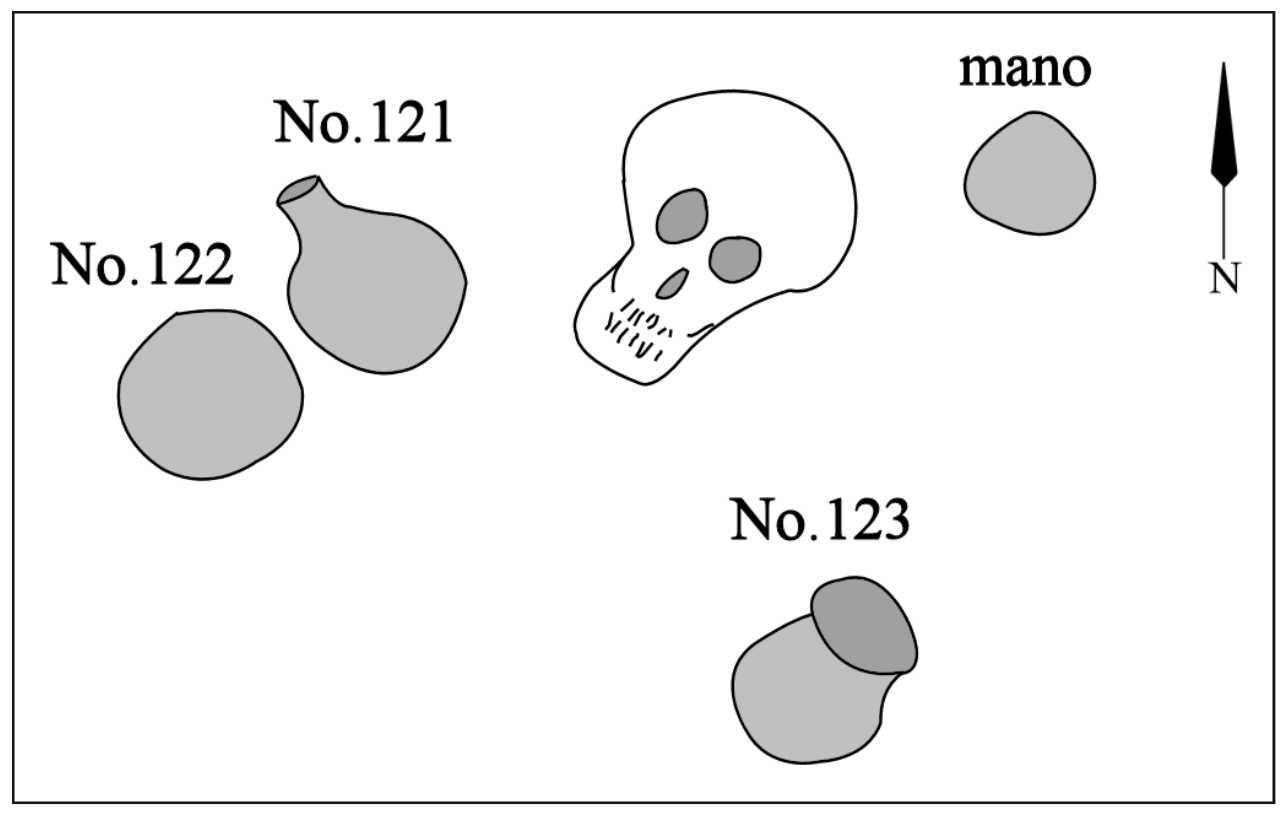

Figure 21. Burial I-17 at the Goode Hunt site.

\section{Ceramic Vessels from Burial Features}

SITE NAME OR SITE NUMBER: Goode Hunt (41CS23)

VESSEL NO.: 1, isolated find east of Burial I-11 (see Figure 3). The small size of the vessel suggests it was likely placed with a child whose bones have eroded away since the deceased was interred.

VESSEL FORM: Carinated bowl with three rim peaks

NON-PLASTICS AND PASTE: grog

RIM AND LIP FORM: Inverted rim and rounded lip

CORE COLOR: F (fired in a reducing environment and cooled in the open air)

INTERIOR SURFACE COLOR: dark reddish-brown; fire clouds on the rim and body

EXTERIOR SURFACE COLOR: dark reddish-brown; fire clouds on the rim, body, and base

WALL THICKNESS (IN MM): rim, $6.2 \mathrm{~mm}$

INTERIOR SURFACE TREATMENT: burnished on rim; smoothed on the body

EXTERIOR SURFACE TREATMENT: burnished 
HEIGHT (IN CM): 3.7

ORIFICE DIAMETER (IN CM): 9.6

DIAMETER AT BOTTOM OF RIM OR NECK (IN CM): 10.4

BASE DIAMETER (IN CM) AND SHAPE OF BASE: 4.8; circular and rounded

ESTIMATED VOLUME (IN LITERS): 0.22

DECORATION (INCLUDING MOTIF AND ELEMENTS WHEN APPARENT): The rim is divided into six engraved panels defined by a single upper horizontal engraved line with excised and downward-pointing tick marks and sets of vertical and curvilinear lines (Figure 22). Within the panel are a horizontal engraved scroll line as well as two horizontal engraved lines with downward-pointing excised tick marks.

PIGMENT USE AND LOCATION ON VESSEL: none

TYPE AND VARIETY (IF KNOWN): cf. Simms Engraved

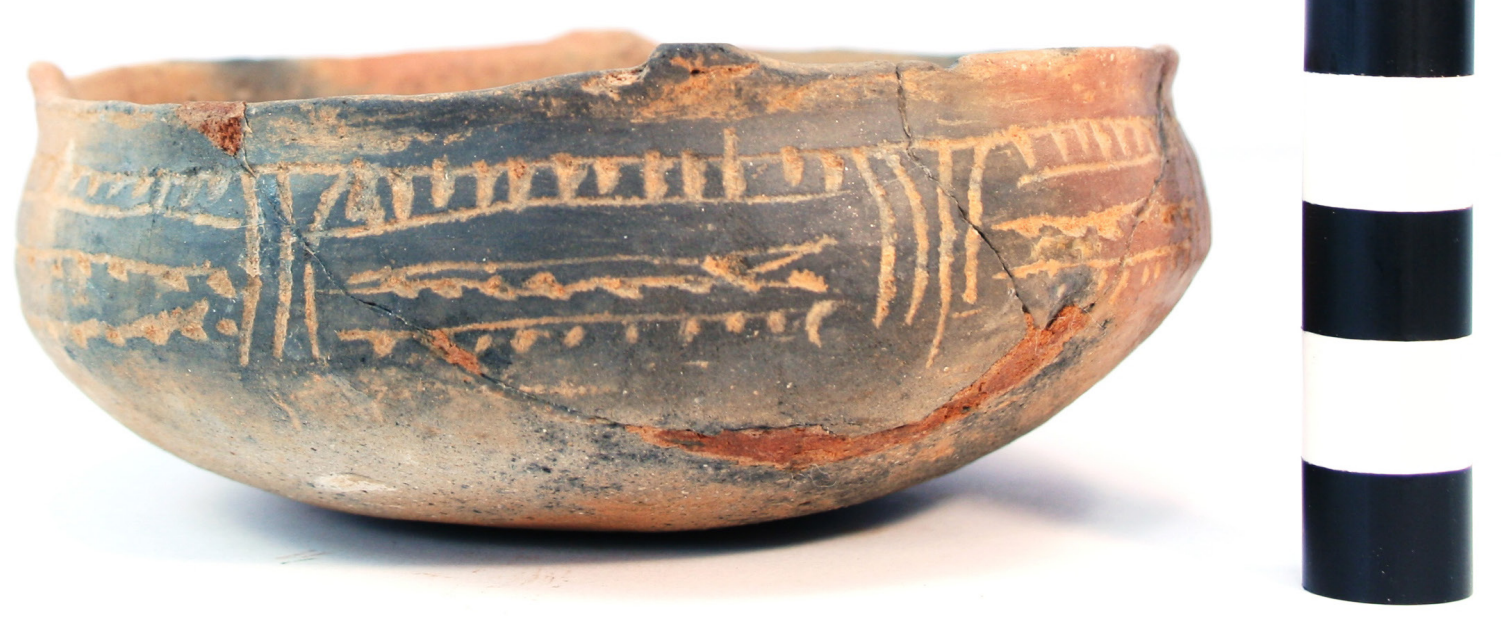

Figure 22. cf. Simms Engraved carinated bowl (Vessel No. 1) from the Goode Hunt site, possibly from a child burial. 
SITE NAME OR SITE NUMBER: Goode Hunt

VESSEL NO.: 12, Burial I-1

VESSEL FORM: Bottle

NON-PLASTICS AND PASTE: bone

RIM AND LIP FORM: Direct rim and rounded lip

CORE COLOR: B (fired and cooled in a reducing environment)

INTERIOR SURFACE COLOR: very dark gray

EXTERIOR SURFACE COLOR: very dark gray; fire clouds on the base

WALL THICKNESS (IN MM): rim, $5.2 \mathrm{~mm}$

INTERIOR SURFACE TREATMENT: none

EXTERIOR SURFACE TREATMENT: burnished

HEIGHT (IN CM): 17.8

ORIFICE DIAMETER (IN CM): 4.1

DIAMETER AT BOTTOM OF RIM OR NECK

(IN CM): $5.1 ; 12.5 \mathrm{~cm}$ maximum body diameter

\section{BASE DIAMETER (IN CM) AND SHAPE OF}

BASE: 5.1; circular and rounded

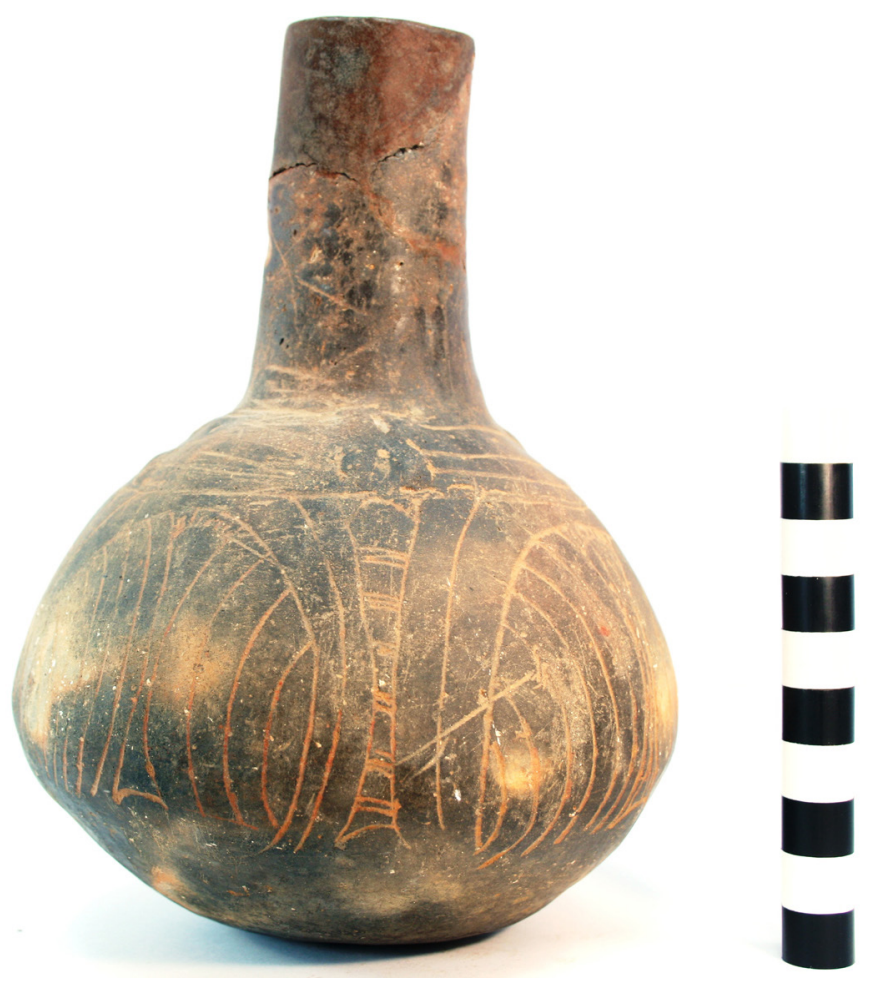

Figure 23. Hatchel Engraved bottle (Vessel No. 12) from Burial I-1 at the Goode Hunt site.

\section{ESTIMATED VOLUME (IN LITERS): 036}

DECORATION (INCLUDING MOTIF AND ELEMENTS WHEN APPARENT): Beneath three horizontal engraved lines on the upper vessel body are four semi-circular panels with engraved elements. The horizontal lines are bisected by two sets of two low appliqued ridges, and there are another two sets of small appliqued circles between the central and lowest horizontal engraved lines (Figure 23). These appliqued elements are set above the engraved bracket elements that divide the engraved body panels.

The panels on the vessel body are divided by engraved bracket elements with sets of 2-3 short horizontal engraved lines (Figure 23). The panels have a single centrally-placed engraved semi-circle filled with concentric semi-circular lines on either side of a hatched bracket element.

PIGMENT USE AND LOCATION ON VESSEL: red in the engraved lines

TYPE AND VARIETY (IF KNOWN): Hatchel Engraved (Suhm and Jelks 1962:Plate 34) 
SITE NAME OR SITE NUMBER: Goode Hunt

VESSEL NO.: 14, Burial I-2

VESSEL FORM: Bottle with a spool neck

NON-PLASTICS AND PASTE: bone

RIM AND LIP FORM: Everted rim and rounded lip

CORE COLOR: $\mathrm{G}$ (fired in a reducing environment and cooled in the open air)

INTERIOR SURFACE COLOR: very dark gray

EXTERIOR SURFACE COLOR: dark reddishbrown; fire clouds on the rim, body, and base

WALL THICKNESS (IN MM): rim, $4.4 \mathrm{~mm}$

INTERIOR SURFACE TREATMENT: none

EXTERIOR SURFACE TREATMENT: burnished

HEIGHT (IN CM): 12.1

ORIFICE DIAMETER (IN CM): 4.4

DIAMETER AT BOTTOM OF RIM OR NECK

(IN CM): 4.4; maximum body diameter of $9.5 \mathrm{~cm}$

BASE DIAMETER (IN CM) AND SHAPE OF

BASE: 5.0; circular and rounded

ESTIMATED VOLUME (IN LITERS): 0.24

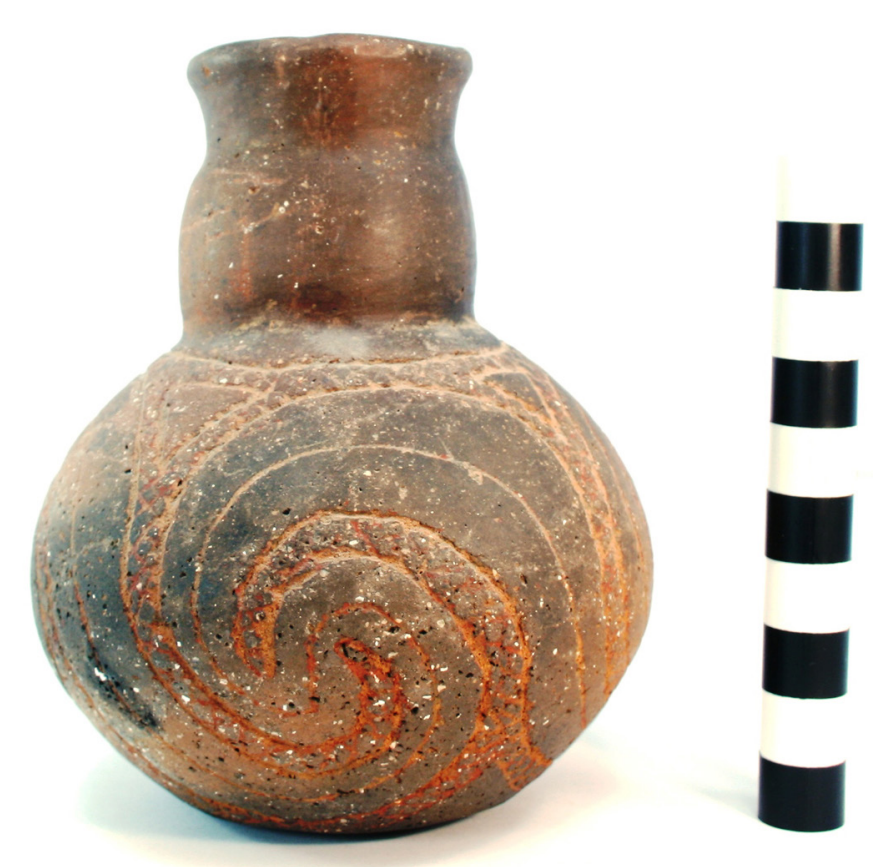

Figure 24. Hodges Engraved bottle (Vessel No. 14) from Burial I-2 at the Goode Hunt site.

DECORATION (INCLUDING MOTIF AND ELEMENTS WHEN APPARENT): The vessel has an engraved meandering scroll line between four upper and lower sets of cross-hatched hooked arm elements (Figure 24). The upper hooked arm element has four sets of negative triangles while the lower hooked arm element is bifurcated into two curvilinear cross-hatched zones.

PIGMENT USE AND LOCATION ON VESSEL: red pigment in the engraved lines

TYPE AND VARIETY (IF KNOWN): Hodges Engraved 
SITE NAME OR SITE NUMBER: Goode Hunt

VESSEL NO.: 15, Burial I-2

VESSEL FORM: Carinated bowl

NON-PLASTICS AND PASTE: grog

RIM AND LIP FORM: Inverted rim and rounded lip

CORE COLOR: $\mathrm{G}$ (fired in a reducing environment and cooled in the open air)

INTERIOR SURFACE COLOR: dark grayish-brown

EXTERIOR SURFACE COLOR: yellowish-brown; fire clouds on the rim and body

WALL THICKNESS (IN MM): rim, $5.3 \mathrm{~mm}$

INTERIOR SURFACE TREATMENT: smoothed

EXTERIOR SURFACE TREATMENT: burnished

HEIGHT (IN CM): 14.6

ORIFICE DIAMETER (IN CM): 20.9

DIAMETER AT BOTTOM OF RIM OR NECK (IN CM): 21.5

BASE DIAMETER (IN CM) AND SHAPE OF

BASE: 7.0; circular and flat

Figure 25. Simms Engraved carinated bowl (Vessel No. 15) from Burial I-2 at the Goode Hunt site.

ESTIMATED VOLUME (IN LITERS): 2.8

DECORATION (INCLUDING MOTIF AND ELEMENTS WHEN APPARENT): The rim has single upper and lower horizontal engraved lines, and is divided into four horizontal panels (Figure 25). There is a single horizontal scroll element within each panel. The panels are divided by open vertical brackets.

PIGMENT USE AND LOCATION ON VESSEL: none

TYPE AND VARIETY (IF KNOWN): Simms Engraved 
SITE NAME OR SITE NUMBER: Goode Hunt

VESSEL NO.: 16, Burial I-2

VESSEL FORM: Jar

NON-PLASTICS AND PASTE: grog

RIM AND LIP FORM: Everted rim and rounded lip; lip notched

CORE COLOR: $\mathrm{G}$ (fired in a reducing environment and cooled in the open air)

INTERIOR SURFACE COLOR: very dark gray

EXTERIOR SURFACE COLOR: dark reddishbrown; fire clouds on the rim, body, and base

WALL THICKNESS (IN MM): rim, $7.0 \mathrm{~mm}$

INTERIOR SURFACE TREATMENT: smoothed

EXTERIOR SURFACE TREATMENT: none

HEIGHT (IN CM): 18.5

ORIFICE DIAMETER (IN CM): 15.2

DIAMETER AT BOTTOM OF RIM OR NECK (IN CM): 15.0

BASE DIAMETER (IN CM) AND SHAPE OF BASE: 5.7 ; circular and flat

ESTIMATED VOLUME (IN LITERS): 2.5

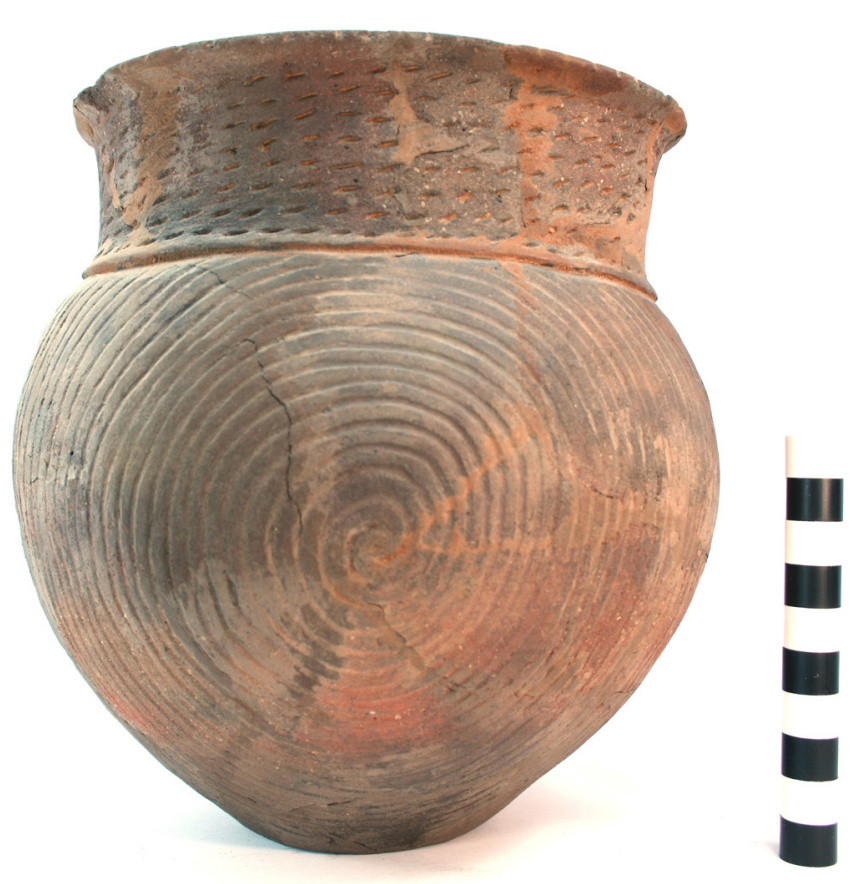

Figure 26. Foster Trailed-Incised, var. Moore jar (Vessel No. 16) from Burial I-2 at the Goode Hunt site.

DECORATION (INCLUDING MOTIF AND ELEMENTS WHEN APPARENT): The rim of the vessel has eight horizontal rows of diagonal tool punctations (Figure 26). The vessel body has two sets of concentric trailed circles that end in hooked arms; the concentric trailed circles extend to the vessel base.

PIGMENT USE AND LOCATION ON VESSEL: none

TYPE AND VARIETY (IF KNOWN): Foster Trailed-Incised, var. Moore (Schambach and Miller 1984:Figure 11-10) 
SITE NAME OR SITE NUMBER: Goode Hunt

VESSEL NO.: 18, Burial I-2

VESSEL FORM: Carinated bowl

NON-PLASTICS AND PASTE: bone

RIM AND LIP FORM: Inverted rim and rounded lip

CORE COLOR: $\mathrm{G}$ (fired in a reducing environment and cooled in the open air)

INTERIOR SURFACE COLOR: dark grayish-brown

EXTERIOR SURFACE COLOR: dark reddish-brown; fire clouds on the rim and body

WALL THICKNESS (IN MM): rim, $4.9 \mathrm{~mm}$

INTERIOR SURFACE TREATMENT: burnished

EXTERIOR SURFACE TREATMENT: burnished

HEIGHT (IN CM): 8.6

ORIFICE DIAMETER (IN CM): 15.4

DIAMETER AT BOTTOM OF RIM OR NECK (IN CM): 15.9

BASE DIAMETER (IN CM) AND SHAPE OF BASE: 6.4; circular and flat

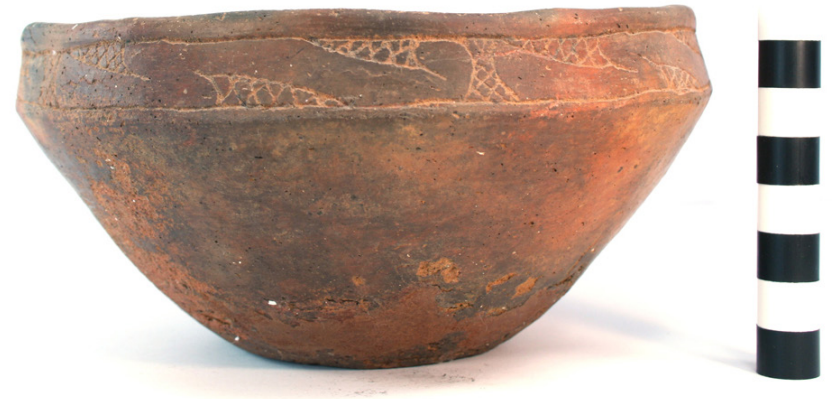

Figure 27. Hodges Engraved carinated bowl (Vessel No. 18) from Burial I-2 at the Goode Hunt site.

ESTIMATED VOLUME (IN LITERS): 0.79

DECORATION (INCLUDING MOTIF AND ELEMENTS WHEN APPARENT): The rim has five sets of negative scrolls outlined by upper and lower sets of triangular-shaped elements filled with cross-hatched lines (Figure 27); two of these elements have a spur extending from one end of the triangles. The negative scrolls are divided by vertical brackets filled with cross-hatched engraved lines.

PIGMENT USE AND LOCATION ON VESSEL: none

TYPE AND VARIETY (IF KNOWN): Hodges Engraved 
SITE NAME OR SITE NUMBER: Goode Hunt

VESSEL NO.: 19, Burial I-2

VESSEL FORM: Jar

NON-PLASTICS AND PASTE: bone

RIM AND LIP FORM: Everted and exterior thickened rim and rounded lip; lip notched

CORE COLOR: $\mathrm{G}$ (fired in a reducing environment and cooled in the open air)

INTERIOR SURFACE COLOR: dark grayishbrown

EXTERIOR SURFACE COLOR: yellowishbrown; fire clouds on the rim, body, and base

WALL THICKNESS (IN MM): rim, $7.3 \mathrm{~mm}$

INTERIOR SURFACE TREATMENT: smoothed

EXTERIOR SURFACE TREATMENT: smoothed on the body

HEIGHT (IN CM): 38.5

ORIFICE DIAMETER (IN CM): 30.8

DIAMETER AT BOTTOM OF RIM OR NECK (IN CM): 29.6

BASE DIAMETER (IN CM) AND SHAPE OF

BASE: 7.6; circular and concave

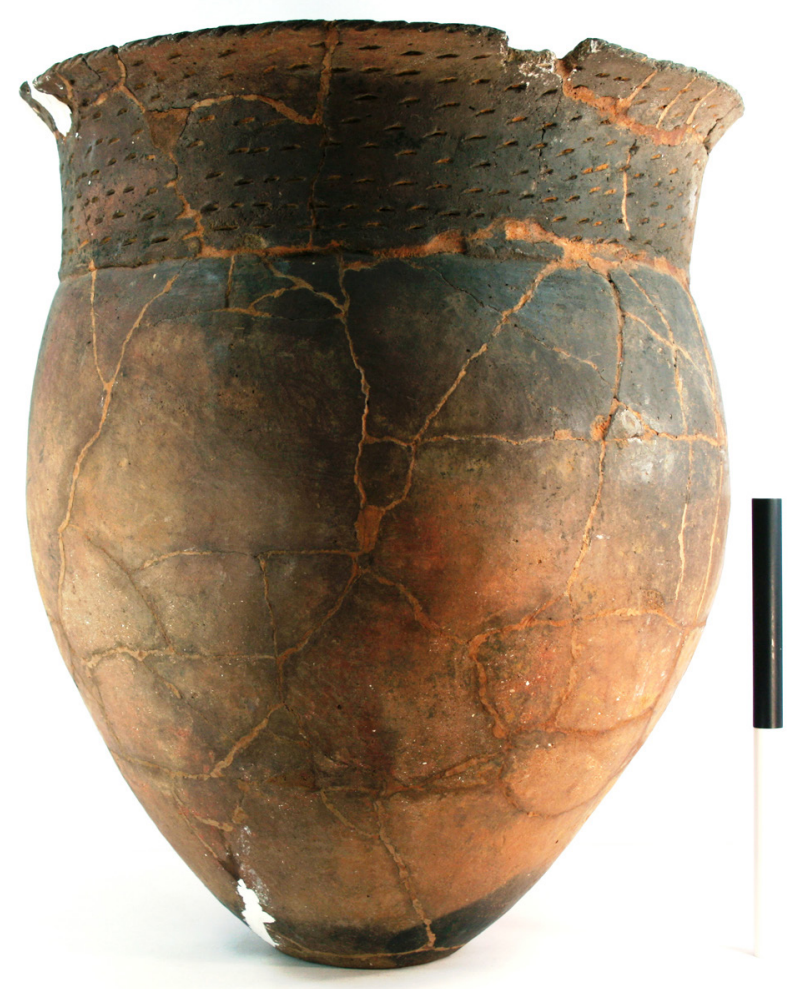

Figure 28. Mockingbird Punctated jar (Vessel No. 19)

ESTIMATED VOLUME (IN LITERS): 15.4 in Burial I-2 at the Goode Hunt site.

DECORATION (INCLUDING MOTIF AND ELEMENTS WHEN APPARENT): Beginning under the vessel lip, there are nine rows of diagonal fingernail punctations on the rim (Figure 28).

PIGMENT USE AND LOCATION ON VESSEL: none

TYPE AND VARIETY (IF KNOWN): Mockingbird Punctated 
SITE NAME OR SITE NUMBER: Goode Hunt

VESSEL NO.: 21, Burial I-3

VESSEL FORM: Bottle with a spool neck

NON-PLASTICS AND PASTE: grog

RIM AND LIP FORM: Everted rim and rounded lip

CORE COLOR: A (fired and cooled in an

oxidizing environment)

INTERIOR SURFACE COLOR: reddish-brown

EXTERIOR SURFACE COLOR: reddish-brown; fire clouds on the body

WALL THICKNESS (IN MM): rim, $4.9 \mathrm{~mm}$

INTERIOR SURFACE TREATMENT: none

EXTERIOR SURFACE TREATMENT: smoothed

HEIGHT (IN CM): 6.7

ORIFICE DIAMETER (IN CM): 3.7

DIAMETER AT BOTTOM OF RIM OR NECK

(IN CM): 3.2; maximum body diameter of $5.3 \mathrm{~cm}$

BASE DIAMETER (IN CM) AND SHAPE OF

BASE: 3.2; circular and flat

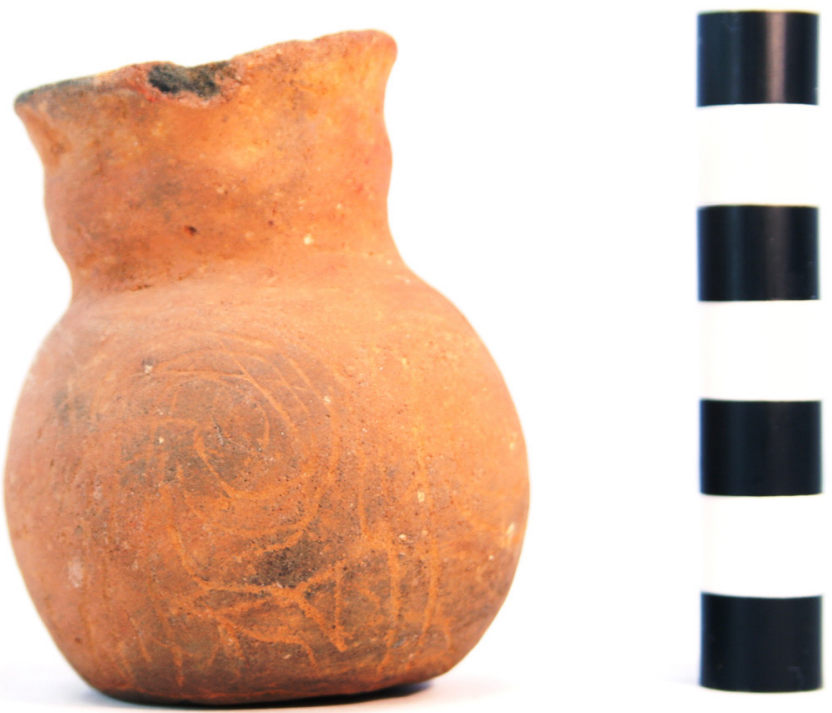

Figure 29. Hodges Engraved bottle (Vessel No. 21) from Burial I-3 at the Goode Hunt site.

\section{ESTIMATED VOLUME (IN LITERS): 0.1}

DECORATION (INCLUDING MOTIF AND ELEMENTS WHEN APPARENT): The vessel body has a faint engraved motif that consists of four individual sets of hatched hooked arm elements and a curvilinear engraved line with an open pendant triangle (Figure 29). The engraved motifs are divided by open vertical brackets.

PIGMENT USE AND LOCATION ON VESSEL: none

TYPE AND VARIETY (IF KNOWN): Hodges Engraved 
SITE NAME OR SITE NUMBER: Goode Hunt

VESSEL NO.: 22, Burial I-3

VESSEL FORM: Carinated bowl

NON-PLASTICS AND PASTE: grog

RIM AND LIP FORM: Direct rim and rounded lip

CORE COLOR: F (fired in a reducing environment and cooled in the open air)

INTERIOR SURFACE COLOR: dark yellowish-brown; fire clouds on the rim, body, and base

EXTERIOR SURFACE COLOR: yellowish-brown; fire clouds on the rim, body, and base

WALL THICKNESS (IN MM): $\operatorname{rim}, 6.3 \mathrm{~mm}$

INTERIOR SURFACE TREATMENT: smoothed

EXTERIOR SURFACE TREATMENT: smoothed

HEIGHT (IN CM): 7.0

ORIFICE DIAMETER (IN CM): 12.1

DIAMETER AT BOTTOM OF RIM OR NECK

(IN CM): 12.2

BASE DIAMETER (IN CM) AND SHAPE OF

BASE: 5.1 ; circular and flat

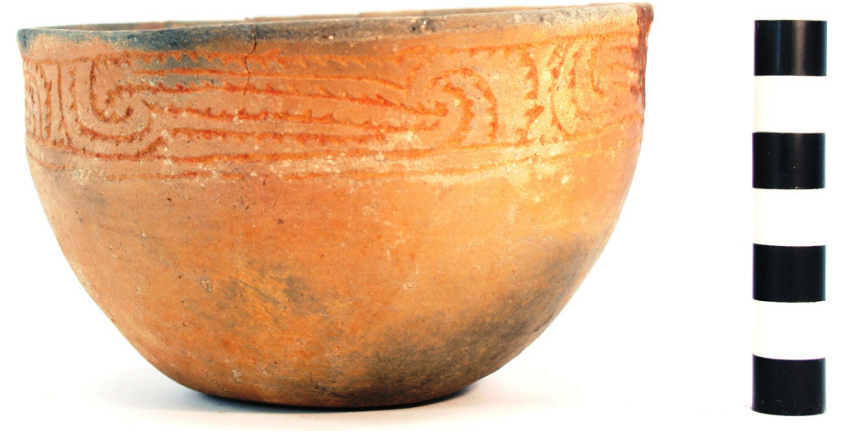

Figure 30. Taylor Engraved carinated bowl (Vessel No. 22) from Burial I-3 at the Goode Hunt site.

ESTIMATED VOLUME (IN LITERS): 0.51

DECORATION (INCLUDING MOTIF AND ELEMENTS WHEN APPARENT): The rim panel is defined by upper and lower horizontal engraved lines and four sets of horizontal scrolls that end in hooked arm elements. The central scroll line has no excised tick marks, but the other scroll lines and hooked arm elements do have excised tick marks (Figure 30). The horizontal scrolls are divided by curvilinear engraved lines with tick marks.

PIGMENT USE AND LOCATION ON VESSEL: none

TYPE AND VARIETY (IF KNOWN): Taylor Engraved 
SITE NAME OR SITE NUMBER: Goode Hunt

VESSEL NO.: 23, Burial I-3

VESSEL FORM: Bowl

NON-PLASTICS AND PASTE: grog

RIM AND LIP FORM: Direct rim and rounded lip

CORE COLOR: $\mathrm{F}$ (fired in a reducing environment and cooled in the open air)

INTERIOR SURFACE COLOR: dark yellowish-brown; fire clouds on the base

EXTERIOR SURFACE COLOR: dark yellowish-

brown; fire clouds on the body and base

WALL THICKNESS (IN MM): rim, $4.3 \mathrm{~mm}$

INTERIOR SURFACE TREATMENT: smoothed

EXTERIOR SURFACE TREATMENT:

smoothed

HEIGHT (IN CM): 5.1

ORIFICE DIAMETER (IN CM): 9.4

DIAMETER AT BOTTOM OF RIM OR NECK

(IN CM): N/A

BASE DIAMETER (IN CM) AND SHAPE OF

BASE: 5.2; circular and flat

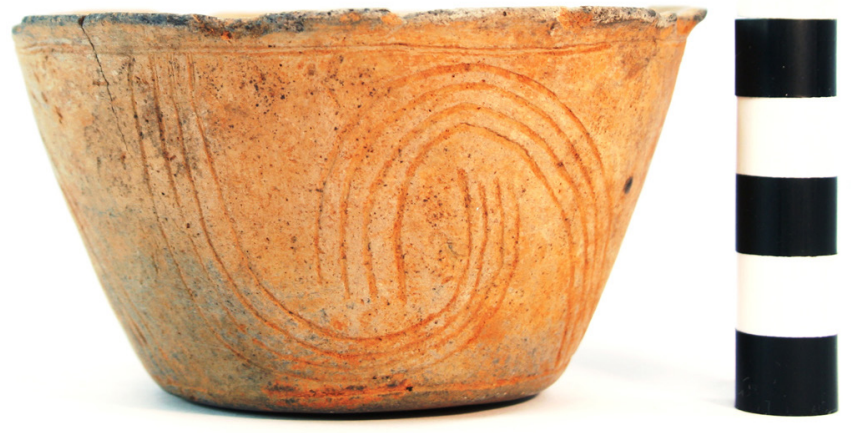

Figure 31. Keno Trailed, var. Phillips bowl (Vessel No. 23) from Burial I-3 at the Goode Hunt site.

ESTIMATED VOLUME (IN LITERS): 0.19

DECORATION (INCLUDING MOTIF AND ELEMENTS WHEN APPARENT): There are single horizontal trailed lines under the vessel lip and above the base, between which are four sets of upper and lower curvilinear trailed lines that hook around each other (Figure 31). Each set consist of four upper and four lower curvilinear trailed lines.

PIGMENT USE AND LOCATION ON VESSEL: none

TYPE AND VARIETY (IF KNOWN): Keno Trailed, var. Phillips (Schambach and Miller 1984:123) 
SITE NAME OR SITE NUMBER: Goode Hunt

VESSEL NO.: 24, Burial I-3

VESSEL FORM: Carinated bowl, hubcap style

NON-PLASTICS AND PASTE: shell

RIM AND LIP FORM: Inverted-direct rim and rounded lip

CORE COLOR: B (fired and cooled in a reducing environment)

INTERIOR SURFACE COLOR: very dark gray; fire clouds on the rim

EXTERIOR SURFACE COLOR: very dark gray; fire clouds on the rim, body, and base

WALL THICKNESS (IN MM): rim, $5.1 \mathrm{~mm}$; body, $4.1 \mathrm{~mm}$

INTERIOR SURFACE TREATMENT: smoothed

EXTERIOR SURFACE TREATMENT:

burnished

HEIGHT (IN CM): 8.3

ORIFICE DIAMETER (IN CM): 16.8

DIAMETER AT BOTTOM OF RIM OR NECK

(IN CM): 18.5

BASE DIAMETER (IN CM) AND SHAPE OF

BASE: 5.1; circular and rounded

ESTIMATED VOLUME (IN LITERS): 0.83

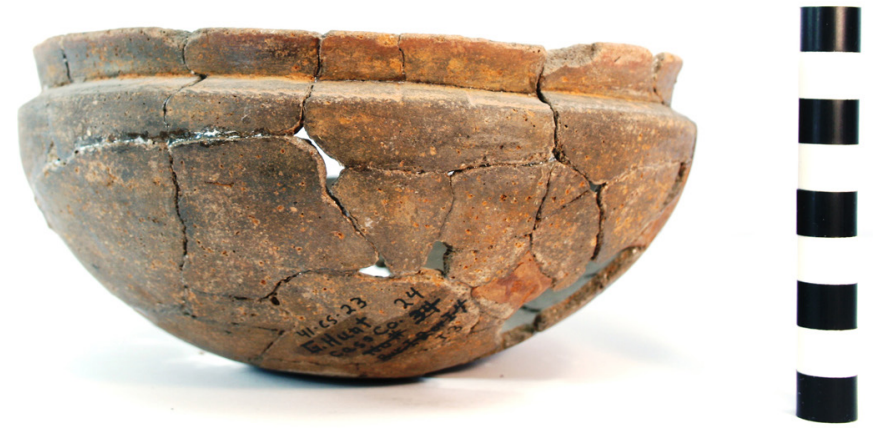

Figure 32. Simms Engraved, var. Darco carinated bowl (Vessel No. 24) from Burial I-3 at the Goode Hunt site.

DECORATION (INCLUDING MOTIF AND ELEMENTS WHEN APPARENT): The rim is divided into four panels by sets of vertical engraved lines. Between the vertical line dividers are two diagonal engraved lines with either upward- or downward-pointing excised tick marks (Figure 32).

PIGMENT USE AND LOCATION ON VESSEL: none

TYPE AND VARIETY (IF KNOWN): Simms Engraved, var. Darco 
SITE NAME OR SITE NUMBER: Goode Hunt

VESSEL NO.: 25, Burial I-3

VESSEL FORM: Carinated bowl

NON-PLASTICS AND PASTE: grog

RIM AND LIP FORM: Inverted rim and rounded lip

CORE COLOR: F (fired in a reducing environment and cooled in the open air)

INTERIOR SURFACE COLOR: yellowish-brown; fire clouds on the body and base

EXTERIOR SURFACE COLOR: yellowish-brown; fire clouds on the rim, body, and base

WALL THICKNESS (IN MM): rim, $5.5 \mathrm{~mm}$

INTERIOR SURFACE TREATMENT: smoothed

EXTERIOR SURFACE TREATMENT: burnished

HEIGHT (IN CM): 8.2

ORIFICE DIAMETER (IN CM): 11.7

DIAMETER AT BOTTOM OF RIM OR NECK

(IN CM): 14.4

BASE DIAMETER (IN CM) AND SHAPE OF

BASE: 5.1; circular and rounded

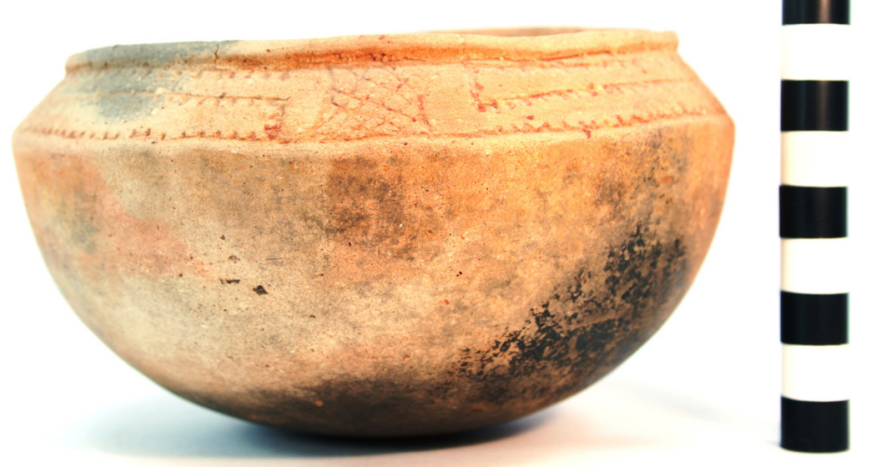

Figure 33. Simms Engraved carinated bowl (Vessel No. 25) from Burial I-3 at the Goode Hunt site.

ESTIMATED VOLUME (IN LITERS): 0.58

DECORATION (INCLUDING MOTIF AND ELEMENTS WHEN APPARENT): The rim has upper and lower horizontal engraved lines with excised tick marks, and is divided into four panels by brackets filled with cross-hatched engraved lines (Figure 33). Each panel has a single horizontal and vertical line with downward- or sideways-pointing excised tick marks.

PIGMENT USE AND LOCATION ON VESSEL: red pigment in engraved lines

TYPE AND VARIETY (IF KNOWN): Simms Engraved 
SITE NAME OR SITE NUMBER: Goode Hunt

VESSEL NO.: 26, Burial I-3

VESSEL FORM: Jar

NON-PLASTICS AND PASTE: grog

RIM AND LIP FORM: Everted rim and rounded lip

CORE COLOR: F (fired in a reducing environment and cooled in the open air)

INTERIOR SURFACE COLOR: reddish-brown

EXTERIOR SURFACE COLOR: reddish-brown; fire clouds on the rim and body

WALL THICKNESS (IN MM): $\operatorname{rim}, 7.0 \mathrm{~mm}$

INTERIOR SURFACE TREATMENT: smoothed

EXTERIOR SURFACE TREATMENT: smoothed

HEIGHT (IN CM): 19.7

ORIFICE DIAMETER (IN CM): 22.1

DIAMETER AT BOTTOM OF RIM OR NECK (IN CM): 18.5

BASE DIAMETER (IN CM) AND SHAPE OF BASE: 7.0; circular and flat

ESTIMATED VOLUME (IN LITERS): 3.9

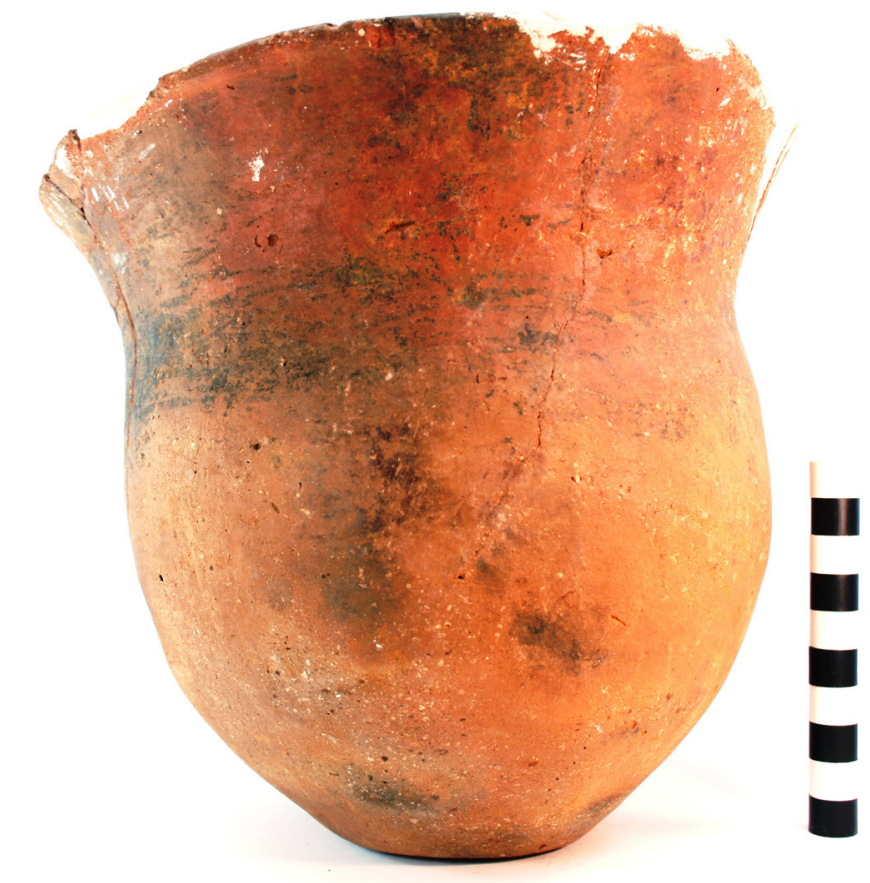

Figure 34. Plain jar (Vessel No. 26) from Burial I-3 at the Goode Hunt site.

DECORATION (INCLUDING MOTIF AND ELEMENTS WHEN APPARENT): Plain (Figure 34)

PIGMENT USE AND LOCATION ON VESSEL: none

TYPE AND VARIETY (IF KNOWN): Unidentified plain ware 
SITE NAME OR SITE NUMBER: Goode Hunt

VESSEL NO.: 32, Burial I-4

VESSEL FORM: Bottle with a spool neck

NON-PLASTICS AND PASTE: bone

RIM AND LIP FORM: Everted rim and rounded lip

CORE COLOR: B (fired and cooled in a reducing environment)

INTERIOR SURFACE COLOR: very dark gray

EXTERIOR SURFACE COLOR: very dark gray to black; fire clouds on the rim and body

WALL THICKNESS (IN MM): rim, $3.1 \mathrm{~mm}$

INTERIOR SURFACE TREATMENT: none

EXTERIOR SURFACE TREATMENT: burnished

HEIGHT (IN CM): 8.2

ORIFICE DIAMETER (IN CM): 2.5

DIAMETER AT BOTTOM OF RIM OR NECK

(IN CM): 2.7; maximum body diameter of $7.5 \mathrm{~cm}$

BASE DIAMETER (IN CM) AND SHAPE OF

BASE: 3.1 ; circular and concave

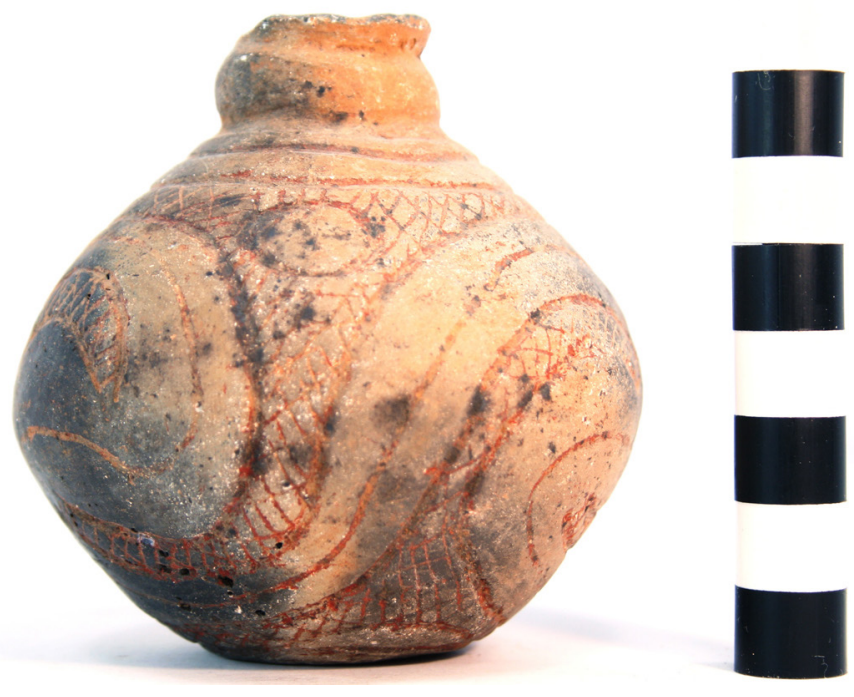

Figure 35. Hodges Engraved bottle (Vessel No. 35)

ESTIMATED VOLUME (IN LITERS): 0.1

from Burial I-4 at the Goode Hunt site.

DECORATION (INCLUDING MOTIF AND ELEMENTS WHEN APPARENT): There are two horizontal engraved lines at the top of the vessel body, along with a meandering scroll marked by a central scroll line (Figure 35). On either side of the meandering scroll line are three sets of upper and lower cross-hatched zones that end in hooked arms. The upper cross-hatched zones each have a single negative circle, while the lower cross-hatched zones have a single negative semi-circle (Figure 35).

PIGMENT USE AND LOCATION ON VESSEL: none

TYPE AND VARIETY (IF KNOWN): Hodges Engraved 
SITE NAME OR SITE NUMBER: Goode Hunt

VESSEL NO.: 35, Burial I-4

VESSEL FORM: Carinated bowl, hubcap style

NON-PLASTICS AND PASTE: grog

RIM AND LIP FORM: Inverted-direct rim and rounded lip

CORE COLOR: B (fired and cooled in a reducing environment)

INTERIOR SURFACE COLOR: very dark gray; fire clouds on the rim

EXTERIOR SURFACE COLOR: very dark gray; fire clouds on the rim and body

WALL THICKNESS (IN MM): rim, $6.0 \mathrm{~mm}$; body, $5.4 \mathrm{~mm}$

INTERIOR SURFACE TREATMENT: smoothed

EXTERIOR SURFACE TREATMENT: smoothed

HEIGHT (IN CM): 8.2

ORIFICE DIAMETER (IN CM): 14.6

DIAMETER AT BOTTOM OF RIM OR NECK

(IN CM): 15.2

BASE DIAMETER (IN CM) AND SHAPE OF

BASE: 6.4; circular and rounded

ESTIMATED VOLUME (IN LITERS): 0.72

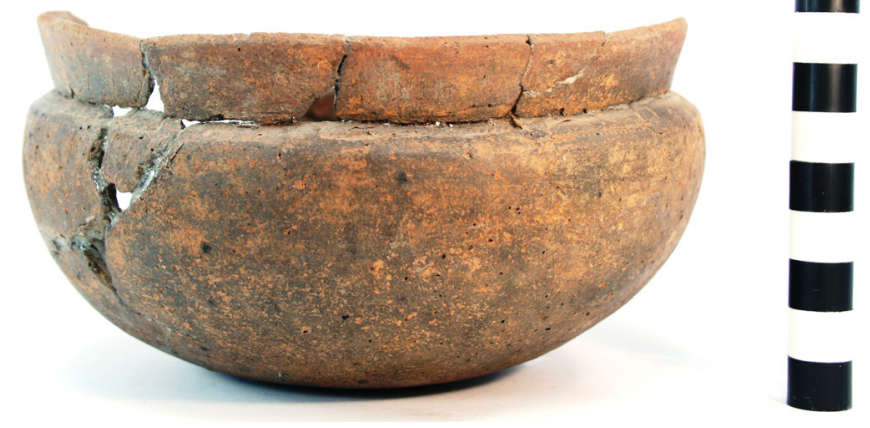

Figure 36. Simms Engraved, var. Darco carinated bowl (Vessel No. 35) from Burial I-4 at the Goode Hunt site.

DECORATION (INCLUDING MOTIF AND ELEMENTS WHEN APPARENT): The lower part of the vessel rim has panels (likely four in number) with upper and lower diagonal engraved lines with either upward- or downward-pointing excised tick marks (Figure 36). The panels are divided by single short vertical engraved lines.

PIGMENT USE AND LOCATION ON VESSEL: none

TYPE AND VARIETY (IF KNOWN): Simms Engraved, var. Darco 
SITE NAME OR SITE NUMBER: Goode Hunt

VESSEL NO.: 36, Burial I-4

VESSEL FORM: Carinated bowl

NON-PLASTICS AND PASTE: grog

RIM AND LIP FORM: Inverted rim and rounded lip

CORE COLOR: $\mathrm{G}$ (fired in a reducing environment)

INTERIOR SURFACE COLOR: very dark gray; fire clouds on the rim

EXTERIOR SURFACE COLOR: dark yellowish-brown; fire clouds on the rim, body, and base

WALL THICKNESS (IN MM): rim, $6.0 \mathrm{~mm}$

INTERIOR SURFACE TREATMENT: smoothed

EXTERIOR SURFACE TREATMENT: burnished

HEIGHT (IN CM): 7.0

ORIFICE DIAMETER (IN CM): 11.5

DIAMETER AT BOTTOM OF RIM OR NECK (IN CM): 12.6

BASE DIAMETER (IN CM) AND SHAPE OF

BASE: 4.3; circular and rounded

ESTIMATED VOLUME (IN LITERS): 0.48

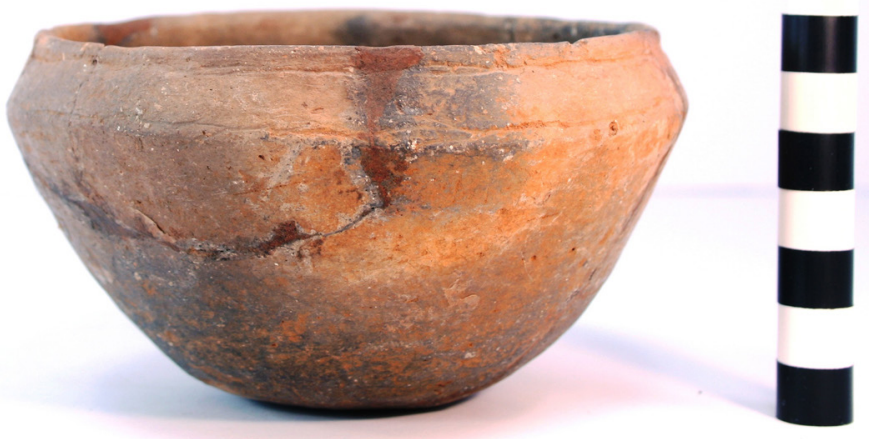

Figure 37. Simms Engraved carinated bowl (Vessel No. 36) in Burial I-4 at the Goode Hunt site.

DECORATION (INCLUDING MOTIF AND ELEMENTS WHEN APPARENT): The rim is divided into two panels by two sets of two vertical engraved lines (Figure 37). There are also single horizontal engraved lines at the top and bottom of the rim.

PIGMENT USE AND LOCATION ON VESSEL: none

TYPE AND VARIETY (IF KNOWN): Simms Engraved 
SITE NAME OR SITE NUMBER: Goode Hunt

VESSEL NO.: 38, Dog burial west of Burial I-2 (see Figure 3).

VESSEL FORM: Compound bowl

NON-PLASTICS AND PASTE: grog

RIM AND LIP FORM: Missing

CORE COLOR: $\mathrm{G}$ (fired in a reducing environment and cooled in the open air)

INTERIOR SURFACE COLOR: dark gray

EXTERIOR SURFACE COLOR: yellowishbrown; fire clouds on the rim and body

WALL THICKNESS (IN MM): rim upper panel, $4.8 \mathrm{~mm}$; rim lower panel, $5.4 \mathrm{~mm}$

INTERIOR SURFACE TREATMENT: smoothed

EXTERIOR SURFACE TREATMENT: burnished

HEIGHT (IN CM): 9.3+

ORIFICE DIAMETER (IN CM): 9.3

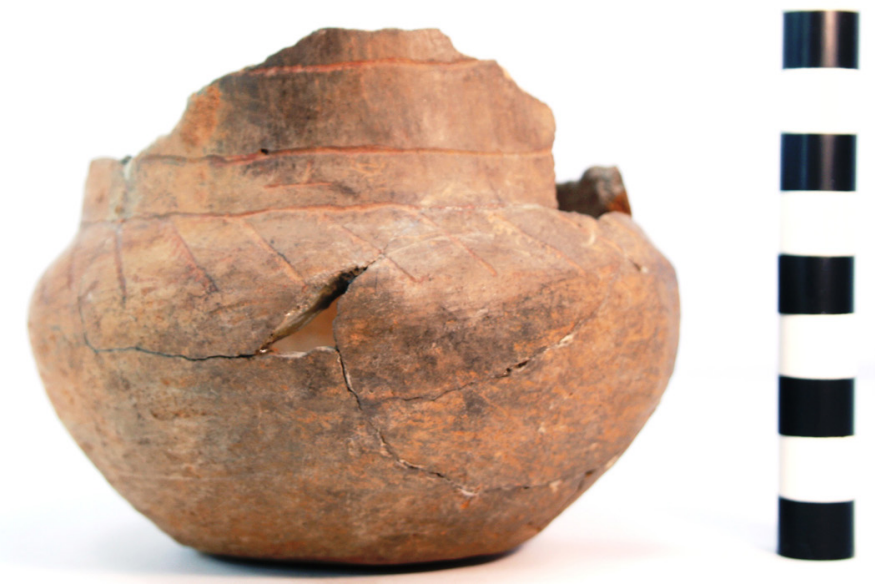

Figure 38. Engraved compound bowl (Vessel No. 38) from the dog burial at the Goode Hunt site.

DIAMETER AT BOTTOM OF RIM OR NECK (IN CM): upper panel, 9.5; lower panel, 10.8

BASE DIAMETER (IN CM) AND SHAPE OF BASE: 5.7; circular and flat

ESTIMATED VOLUME (IN LITERS): 0.68+

DECORATION (INCLUDING MOTIF AND ELEMENTS WHEN APPARENT): The upper rim panel has at least three widely-spaced horizontal engraved lines. The lower rim panel has 22 sets of short diagonal engraved lines, 11 of which have sideways-pointing excised tick marks (Figure 38).

PIGMENT USE AND LOCATION ON VESSEL: none

TYPE AND VARIETY (IF KNOWN): Unidentified fine ware 
SITE NAME OR SITE NUMBER: Goode Hunt

VESSEL NO.: 41, Burial I-5

VESSEL FORM: Carinated bowl

NON-PLASTICS AND PASTE: grog

RIM AND LIP FORM: Inverted rim and rounded lip

CORE COLOR: F (fired in a reducing environment and cooled in the open air)

INTERIOR SURFACE COLOR: reddish-brown

EXTERIOR SURFACE COLOR: dark reddish-brown

WALL THICKNESS (IN MM): rim, 4.6 mm

INTERIOR SURFACE TREATMENT: smoothed

EXTERIOR SURFACE TREATMENT: smoothed

HEIGHT (IN CM): 7.2

ORIFICE DIAMETER (IN CM): 8.9

DIAMETER AT BOTTOM OF RIM OR NECK (IN CM): 11.4

BASE DIAMETER (IN CM) AND SHAPE OF BASE: 4.3; circular and rounded

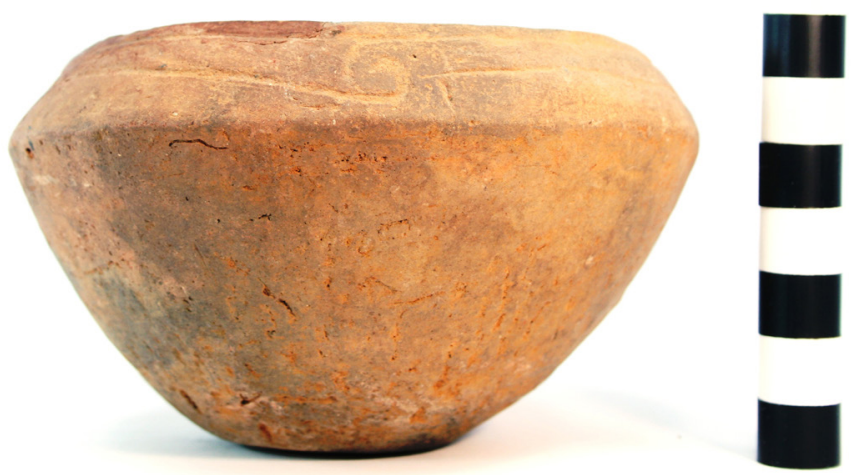

Figure 39. cf. Simms Engraved carinated bowl (Vessel ESTIMATED VOLUME (IN LITERS): 0.38 No. 41) in Burial I-5 at the Goode Hunt site.

DECORATION (INCLUDING MOTIF AND ELEMENTS WHEN APPARENT): The rim is divided into panels by short vertical engraved lines. The panels either have horizontal scroll lines with hooked arm elements (repeated three times), or horizontal and vertical scroll lines (one time) (Figure 39).

PIGMENT USE AND LOCATION ON VESSEL: none

TYPE AND VARIETY (IF KNOWN): cf. Simms Engraved 
SITE NAME OR SITE NUMBER: Goode Hunt

VESSEL NO.: 42, Burial I-5

VESSEL FORM: Jar

NON-PLASTICS AND PASTE: grog

RIM AND LIP FORM: Everted rim and rounded lip

CORE COLOR: $\mathrm{G}$ (fired in a reducing environment and cooled in the open air)

INTERIOR SURFACE COLOR: very dark gray

EXTERIOR SURFACE COLOR: dark yellowish-

brown; fire clouds on the rim, body, and base

WALL THICKNESS (IN MM): rim, $5.4 \mathrm{~mm}$

INTERIOR SURFACE TREATMENT: smoothed

EXTERIOR SURFACE TREATMENT: none

HEIGHT (IN CM): 7.0

ORIFICE DIAMETER (IN CM): 10.2

DIAMETER AT BOTTOM OF RIM OR NECK

(IN CM): 8.8

BASE DIAMETER (IN CM) AND SHAPE OF

BASE: 3.7 ; circular and concave

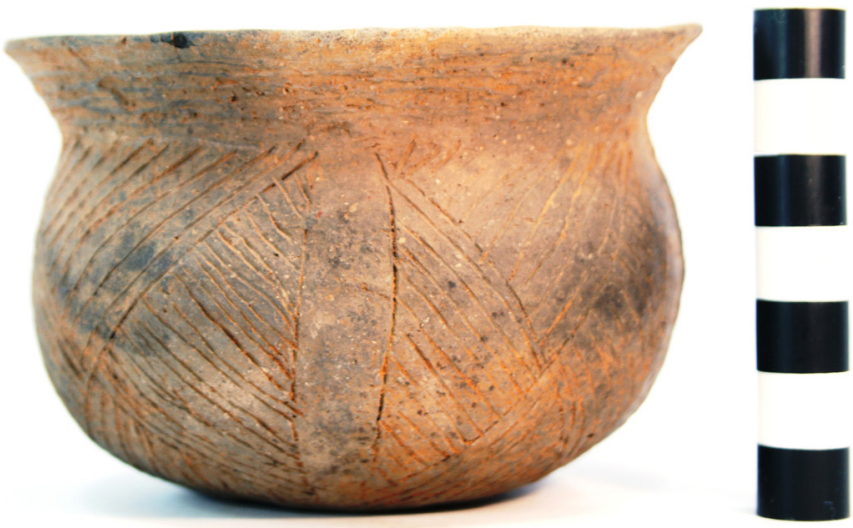

Figure 40. cf. Pease Brushed-Incised jar (Vessel No. 42) from Burial I-5 at the Goode Hunt site.

ESTIMATED VOLUME (IN LITERS): 0.43

DECORATION (INCLUDING MOTIF AND ELEMENTS WHEN APPARENT): The vessel rim has horizontal brushing marks. The vessel body is divided into four panels by sets of two vertical incised lines. The panels are filled with four sets of opposed triangles filled with incised lines pitched in opposing directions (Figure 40).

PIGMENT USE AND LOCATION ON VESSEL: none

TYPE AND VARIETY (IF KNOWN): cf. Pease Brushed-Incised 
SITE NAME OR SITE NUMBER: Goode Hunt

VESSEL NO.: 43, Burial I-5; found inside the vessel were a mussel shell valve with glauconite clay pigment and a deer mandible fragment

VESSEL FORM: Carinated bowl

NON-PLASTICS AND PASTE: grog

RIM AND LIP FORM: Inverted rim and rounded lip

CORE COLOR: B (fired and cooled in a reducing environment)

INTERIOR SURFACE COLOR: very dark brown

EXTERIOR SURFACE COLOR: very dark brown

WALL THICKNESS (IN MM): rim, $6.3 \mathrm{~mm}$

INTERIOR SURFACE TREATMENT: smoothed

EXTERIOR SURFACE TREATMENT: burnished

HEIGHT (IN CM): 6.4

ORIFICE DIAMETER (IN CM): 13.0

DIAMETER AT BOTTOM OF RIM OR NECK

(IN CM): 13.6

BASE DIAMETER (IN CM) AND SHAPE OF

BASE: 5.7; circular and flat

ESTIMATED VOLUME (IN LITERS): 0.50

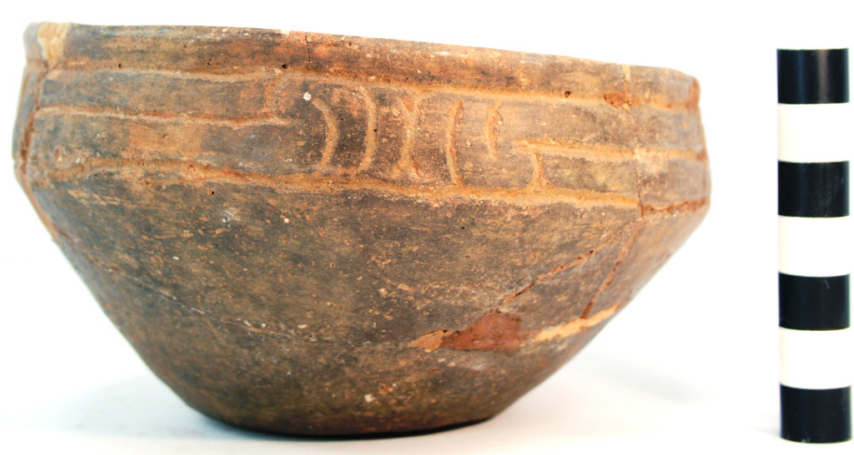

Figure 41. Simms Engraved carinated bowl (Vessel No. 43) in Burial I-5 at the Goode Hunt site.

DECORATION (INCLUDING MOTIF AND ELEMENTS WHEN APPARENT): The rim has upper and lower horizontal engraved lines and four panels divided by single vertical engraved lines that end in upper and lower triangle elements (Figure 41). Within the panels are 1-2 curvilinear engraved lines at either end, along with a horizontal scroll with curvilinear end elements.

PIGMENT USE AND LOCATION ON VESSEL: none

TYPE AND VARIETY (IF KNOWN): Simms Engraved 
SITE NAME OR SITE NUMBER: Goode Hunt

VESSEL NO.: 44, Burial I-5

VESSEL FORM: Carinated bowl

NON-PLASTICS AND PASTE: grog

RIM AND LIP FORM: Inverted rim and rounded lip

CORE COLOR: F (fired in a reducing environment and cooled in the open air)

INTERIOR SURFACE COLOR: yellowish-brown; fire clouds on the rim, body, and base

EXTERIOR SURFACE COLOR: yellowish-brown; fire clouds on the rim, body, and base

WALL THICKNESS (IN MM): rim, $4.6 \mathrm{~mm}$

INTERIOR SURFACE TREATMENT: smoothed

EXTERIOR SURFACE TREATMENT: smoothed

HEIGHT (IN CM): 11.4

ORIFICE DIAMETER (IN CM): 20.3

DIAMETER AT BOTTOM OF RIM OR NECK

(IN CM): 21.4

BASE DIAMETER (IN CM) AND SHAPE OF

BASE: 7.1; circular and flat

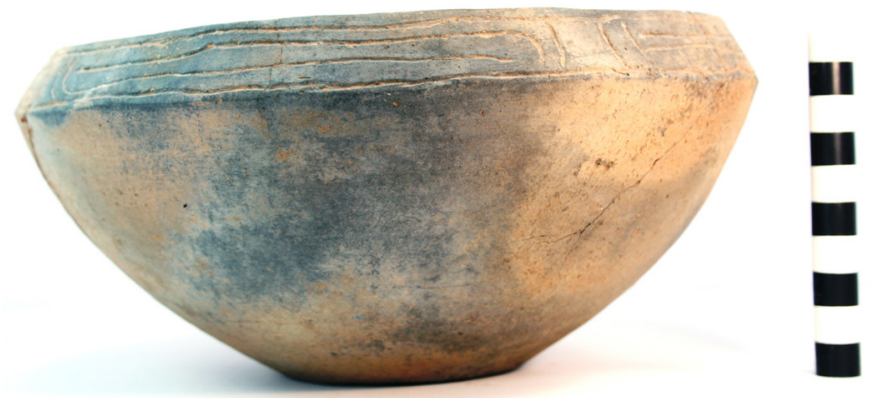

Figure 42. Simms Engraved carinated bowl (Vessel No. 44) in Burial I-5 at the Goode Hunt site.

ESTIMATED VOLUME (IN LITERS): 1.3

DECORATION (INCLUDING MOTIF AND ELEMENTS WHEN APPARENT): The rim of the vessel is divided into four engraved panels by open brackets; the upper and lower portions of the panel are marked by single horizontal engraved lines (Figure 42). Within the panels are two horizontal lines that end with curvilinear or vertical elements that reach to either the upper or lower horizontal engraved lines.

PIGMENT USE AND LOCATION ON VESSEL: white clay pigment in the engraved lines

TYPE AND VARIETY (IF KNOWN): Simms Engraved 
SITE NAME OR SITE NUMBER: Goode Hunt

VESSEL NO.: 45, Burial I-5

VESSEL FORM: Carinated bowl

NON-PLASTICS AND PASTE: bone

RIM AND LIP FORM: Inverted rim and rounded lip

CORE COLOR: $\mathrm{F}$ (fired in a reducing environment and cooled in the open air)

INTERIOR SURFACE COLOR: dark reddish-brown

EXTERIOR SURFACE COLOR: dark reddish-brown; fire clouds on the rim and body

WALL THICKNESS (IN MM): rim, $5.1 \mathrm{~mm}$

INTERIOR SURFACE TREATMENT: smoothed

EXTERIOR SURFACE TREATMENT: burnished

HEIGHT (IN CM): 12.7

ORIFICE DIAMETER (IN CM): 17.8

DIAMETER AT BOTTOM OF RIM OR NECK (IN CM): 19.1

BASE DIAMETER (IN CM) AND SHAPE OF BASE: 5.7; circular and flat

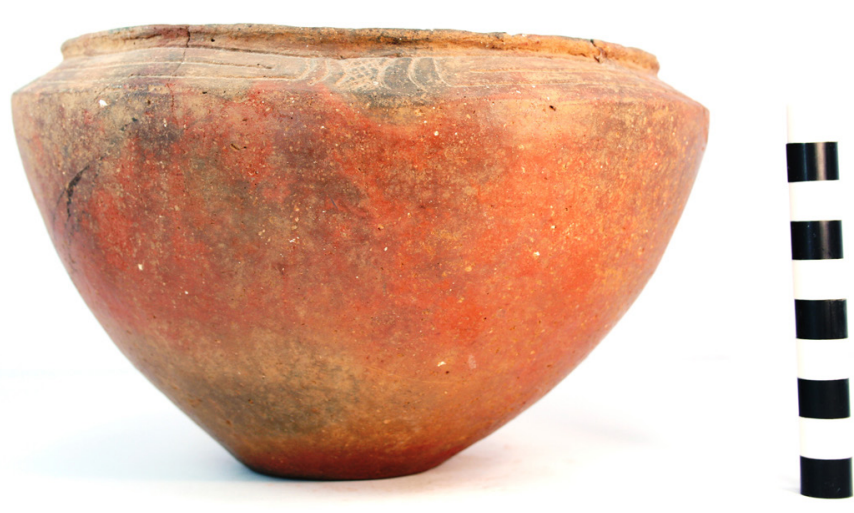

Figure 43. Simms Engraved carinated bowl (Vessel No. 45) in Burial I-5 at the Goode Hunt site.

ESTIMATED VOLUME (IN LITERS): 1.3

DECORATION (INCLUDING MOTIF AND ELEMENTS WHEN APPARENT): The rim is divided into four panels by vertical brackets filled with cross-hatched lines. The panels each have two horizontal and vertical scroll lines and opposing curvilinear engraved lines (Figure 43).

PIGMENT USE AND LOCATION ON VESSEL: none

TYPE AND VARIETY (IF KNOWN): Simms Engraved 
SITE NAME OR SITE NUMBER: Goode Hunt

VESSEL NO.: 46, Burial I-5

VESSEL FORM: Carinated bowl, globular-shaped

NON-PLASTICS AND PASTE: grog

RIM AND LIP FORM: Everted rim and rounded lip; lip notched

CORE COLOR: F (fired in a reducing environment and cooled in the open air)

INTERIOR SURFACE COLOR: reddish-brown; fire clouds on the rim and body

EXTERIOR SURFACE COLOR: reddish-brown; fire clouds on the body and base

WALL THICKNESS (IN MM): $\operatorname{rim}, 6.5 \mathrm{~mm}$

INTERIOR SURFACE TREATMENT: burnished

EXTERIOR SURFACE TREATMENT:

burnished

HEIGHT (IN CM): 8.6

ORIFICE DIAMETER (IN CM): 14.7

DIAMETER AT BOTTOM OF RIM OR NECK

(IN CM): 14.7

BASE DIAMETER (IN CM) AND SHAPE OF

BASE: 5.1; circular and rounded

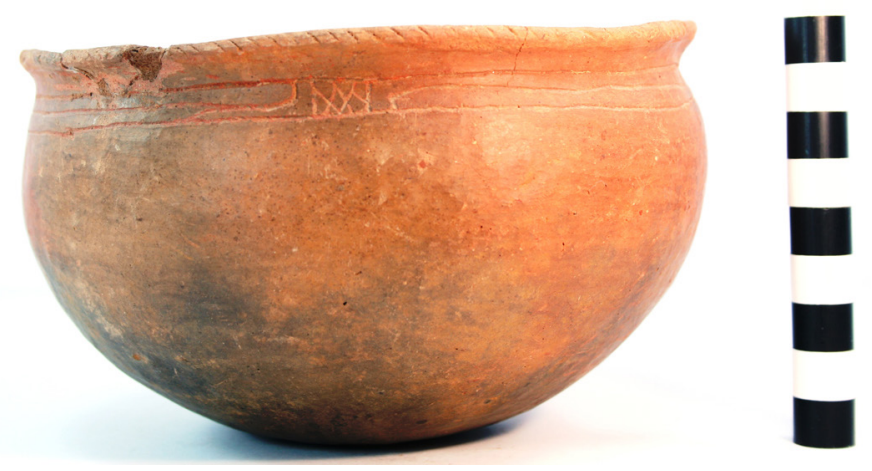

Figure 44. Simms Engraved carinated bowl (Vessel No. 46) in Burial I-5 at the Goode Hunt site.

ESTIMATED VOLUME (IN LITERS): 0.76

DECORATION (INCLUDING MOTIF AND ELEMENTS WHEN APPARENT): The lower portion of the rim of the vessel is divided into four engraved panels by four vertical columns filled with diagonal hatched or cross-hatched lines (Figure 44). The panels themselves have a single horizontal scroll motif.

PIGMENT USE AND LOCATION ON VESSEL: none

TYPE AND VARIETY (IF KNOWN): Simms Engraved 
SITE NAME OR SITE NUMBER: Goode Hunt

VESSEL NO.: 47, Burial I-5

VESSEL FORM: Jar

NON-PLASTICS AND PASTE: grog

RIM AND LIP FORM: Everted rim and rounded lip; lip notched

CORE COLOR: $\mathrm{G}$ (fired in a reducing environment and cooled in the open air)

INTERIOR SURFACE COLOR: very dark gray; fire clouds on the body

EXTERIOR SURFACE COLOR: dark reddishbrown; fire clouds on the rim, body, and base; organic residue on the vessel body

WALL THICKNESS (IN MM): rim, $6.1 \mathrm{~mm}$ INTERIOR SURFACE TREATMENT: smoothed EXTERIOR SURFACE TREATMENT: none HEIGHT (IN CM): 17.6

ORIFICE DIAMETER (IN CM): 15.8

DIAMETER AT BOTTOM OF RIM OR NECK (IN CM): 15.2

BASE DIAMETER (IN CM) AND SHAPE OF BASE: 5.8; circular and concave

ESTIMATED VOLUME (IN LITERS): 2.5

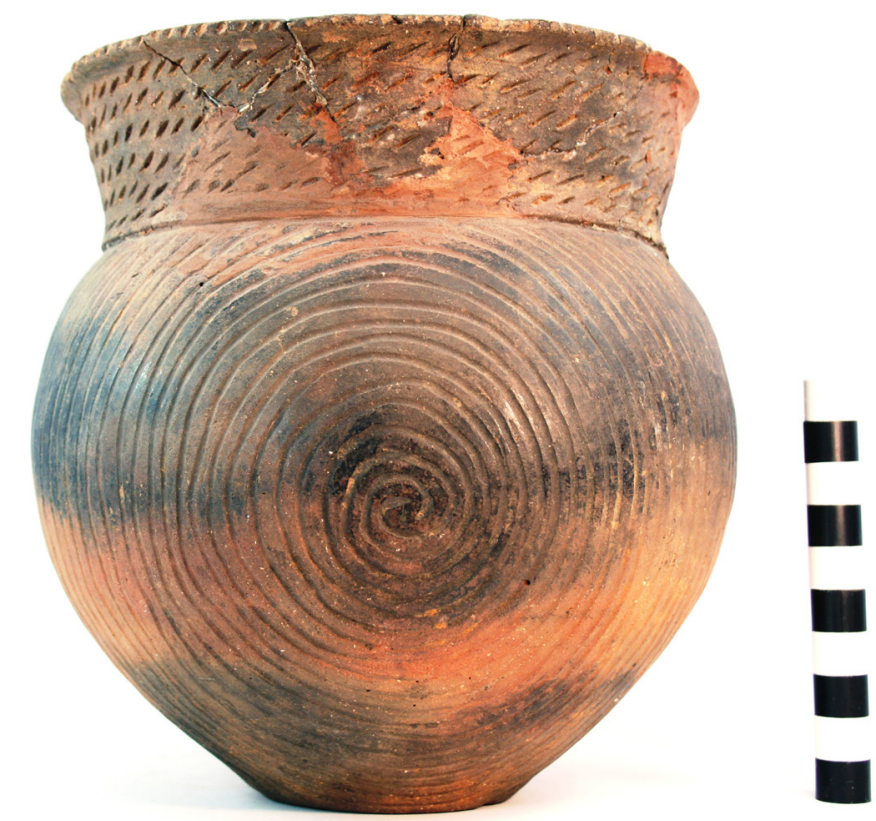

Figure 45. Foster Trailed-Incised, var. Moore jar (Vessel No. 47) in Burial I-5 at the Goode Hunt site.

DECORATION (INCLUDING MOTIF AND ELEMENTS WHEN APPARENT): The rim of the vessel has six horizontal rows of diagonal fingernail punctations (Figure 45). The vessel body has two sets of concentric trailed circles that end in hooked arms; the concentric trailed circles extend to the vessel base.

PIGMENT USE AND LOCATION ON VESSEL: none

TYPE AND VARIETY (IF KNOWN): Foster Trailed-Incised, var. Moore 
SITE NAME OR SITE NUMBER: Goode Hunt

VESSEL NO.: 50, Burial I-6

VESSEL FORM: Bottle with a spool neck

NON-PLASTICS AND PASTE: bone

RIM AND LIP FORM: Everted rim and rounded lip

CORE COLOR: $\mathrm{G}$ (fired in a reducing environment and cooled in the open air)

INTERIOR SURFACE COLOR: dark grayishbrown

EXTERIOR SURFACE COLOR: dark yellowishbrown; fire clouds on the body and base

WALL THICKNESS (IN MM): $\operatorname{rim}, 4.5 \mathrm{~mm}$

INTERIOR SURFACE TREATMENT: none

EXTERIOR SURFACE TREATMENT: smoothed

HEIGHT (IN CM): 6.3

ORIFICE DIAMETER (IN CM): 2.7

DIAMETER AT BOTTOM OF RIM OR NECK

(IN CM): 2.5; maximum body diameter of $5.4 \mathrm{~cm}$

BASE DIAMETER (IN CM) AND SHAPE OF

BASE: 3.0 ; circular and flat

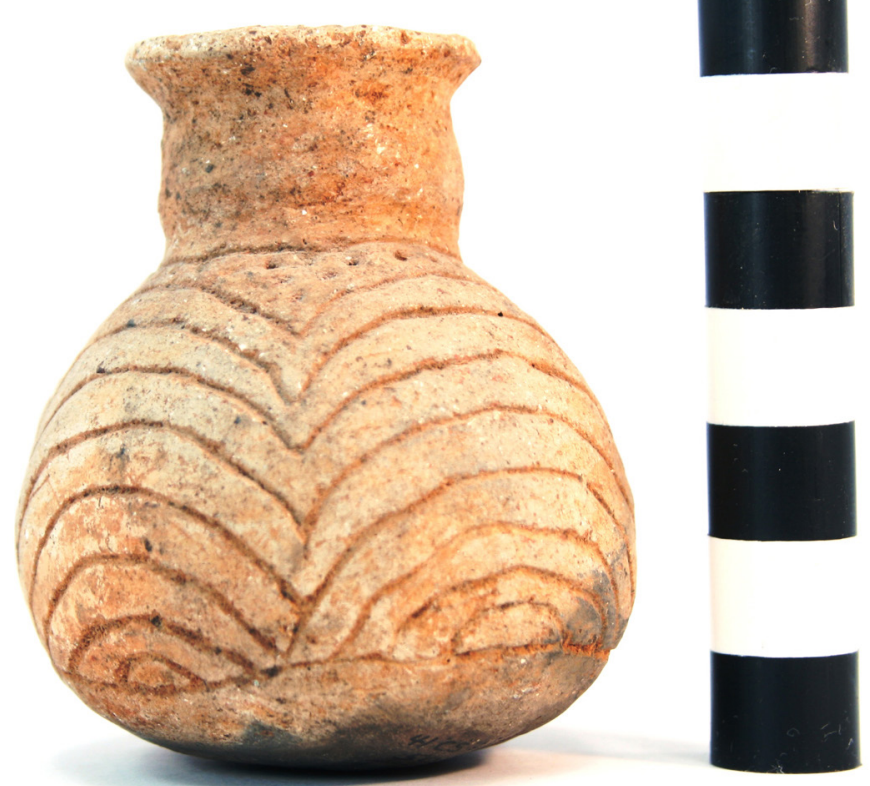

Figure 46. Bailey Engraved bottle (Vessel No. 50) in Burial I-6 at the Goode Hunt site.

\section{ESTIMATED VOLUME (IN LITERS): $<0.1$}

DECORATION (INCLUDING MOTIF AND ELEMENTS WHEN APPARENT): The vessel body has four panels of concentric engraved semi-circular lines, eight lines per panel (Figure 46). Above each of the engraved panels are four triangular zones filled with small excised punctations.

PIGMENT USE AND LOCATION ON VESSEL: none

TYPE AND VARIETY (IF KNOWN): Bailey Engraved 
SITE NAME OR SITE NUMBER: Goode Hunt

VESSEL NO.: 51, Burial I-6

VESSEL FORM: Bowl

NON-PLASTICS AND PASTE: grog

RIM AND LIP FORM: Direct rim and rounded lip; lip notched

CORE COLOR: F (fired in a reducing environment and cooled in the open air)

INTERIOR SURFACE COLOR: yellowish-brown

EXTERIOR SURFACE COLOR: dark yellowish-brown; fire clouds on the body and base

WALL THICKNESS (IN MM): rim, $5.6 \mathrm{~mm}$

INTERIOR SURFACE TREATMENT: smoothed

EXTERIOR SURFACE TREATMENT: burnished

HEIGHT (IN CM): 8.9

ORIFICE DIAMETER (IN CM): 14.2

DIAMETER AT BOTTOM OF RIM OR NECK (IN CM): N/A

BASE DIAMETER (IN CM) AND SHAPE OF BASE: 5.7; circular and flat

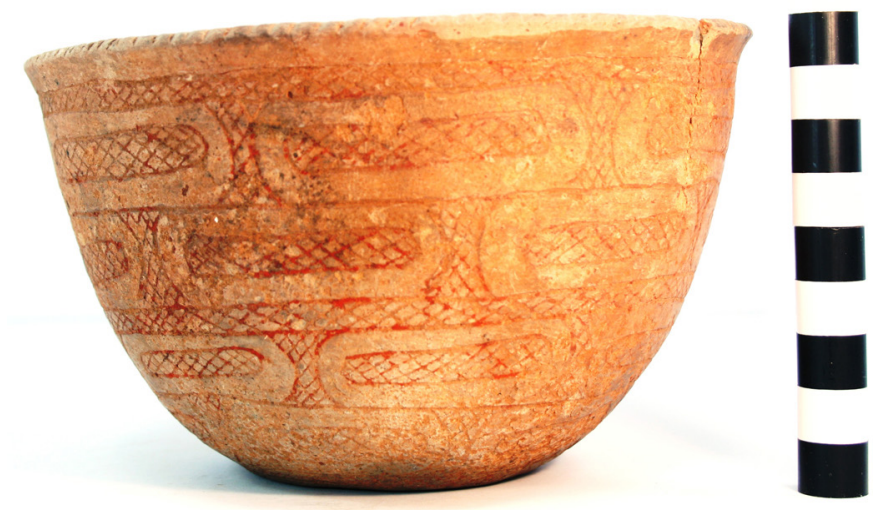

Figure 47. Engraved bowl (Vessel No. 51) in Burial I-6 at the Goode Hunt site.

ESTIMATED VOLUME (IN LITERS): 0.5

DECORATION (INCLUDING MOTIF AND ELEMENTS WHEN APPARENT): The vessel rim and body have a series of four stacked horizontal interlocking panels defined by upper and/or lower horizontal crosshatched zones and cross-hatched interlocking brackets (Figure 47). Within each of the panels are curvilinear zones filled with cross-hatched engraved lines. Gadus (2013:234 and Figure 12) suggests that these horizontal interlocking panels may be representations of turkey feathers "similar to the structure of" a shield or fan held by dancers in Spiro engraved shell art work.

PIGMENT USE AND LOCATION ON VESSEL: red clay pigment rubbed in the engraved lines TYPE AND VARIETY (IF KNOWN): Unidentified fine ware 
SITE NAME OR SITE NUMBER: Goode Hunt

VESSEL NO.: 52, Burial I-6

VESSEL FORM: Deep bowl

NON-PLASTICS AND PASTE: shell

RIM AND LIP FORM: Everted rim and rounded lip

CORE COLOR: $\mathrm{F}$ (fired in a reducing environment and cooled in the open air)

INTERIOR SURFACE COLOR: red

EXTERIOR SURFACE COLOR: red; organic residue on the rim and body

WALL THICKNESS (IN MM): rim, 4.9 mm

INTERIOR SURFACE TREATMENT: smoothed

EXTERIOR SURFACE TREATMENT: burnished

HEIGHT (IN CM): 17.8

ORIFICE DIAMETER (IN CM): 26.0

DIAMETER AT BOTTOM OF RIM OR NECK (IN CM): 20.9

BASE DIAMETER (IN CM) AND SHAPE OF BASE: 8.2; circular and concave

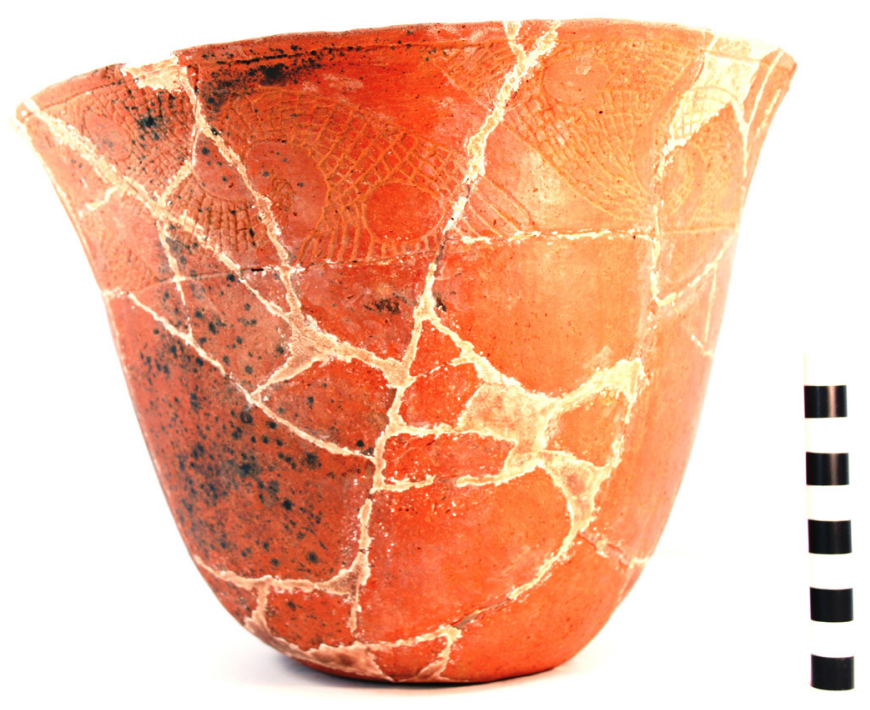

Figure 48. Hodges Engraved deep bowl (Vessel No. 52) in Burial I-6 at the Goode Hunt site.

ESTIMATED VOLUME (IN LITERS): 3.7

DECORATION (INCLUDING MOTIF AND ELEMENTS WHEN APPARENT): The vessel has a red slip on both interior and exterior vessel surfaces. The red-slipped surface has an engraved motif repeated six times around the vessel rim (Figure 48). The motif consists of upper and lower triangular to curvilinearshaped areas that end in hooked arm elements. The triangular to curvilinear-shaped areas are filled with cross-hatched lines, and each area has a single negative circle element (Figure 48).

PIGMENT USE AND LOCATION ON VESSEL: none

TYPE AND VARIETY (IF KNOWN): Hodges Engraved 
SITE NAME OR SITE NUMBER: Goode Hunt

VESSEL NO.: 58, Burial I-7

VESSEL FORM: Carinated bowl

NON-PLASTICS AND PASTE: grog

RIM AND LIP FORM: Inverted rim and rounded lip; lip notched

CORE COLOR: B (fired and cooled in a reducing environment)

INTERIOR SURFACE COLOR: black

EXTERIOR SURFACE COLOR: black

WALL THICKNESS (IN MM): rim, $3.7 \mathrm{~mm}$

INTERIOR SURFACE TREATMENT: burnished

EXTERIOR SURFACE TREATMENT: burnished

HEIGHT (IN CM): 7.0

ORIFICE DIAMETER (IN CM): 14.0

DIAMETER AT BOTTOM OF RIM OR NECK (IN CM): 15.4

BASE DIAMETER (IN CM) AND SHAPE OF

BASE: 5.1; circular and rounded

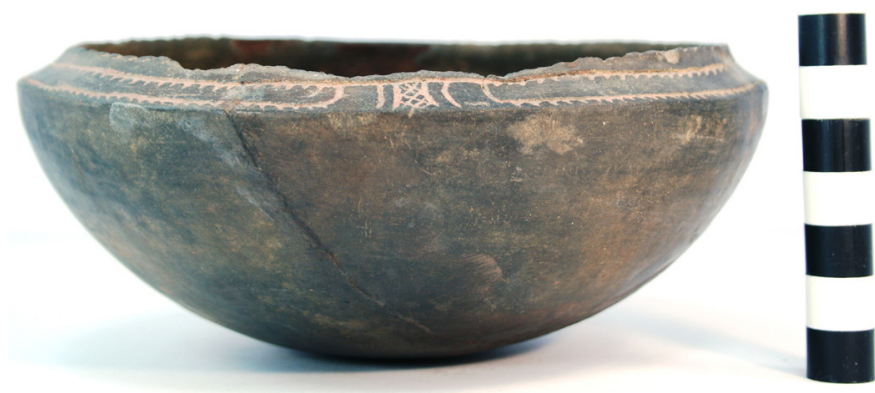

Figure 49. Simms Engraved carinated bowl (Vessel No. 58) in Burial I-7 at the Goode Hunt site.

ESTIMATED VOLUME (IN LITERS): 0.58

DECORATION (INCLUDING MOTIF AND ELEMENTS WHEN APPARENT): The rim of the vessel is divided into four panels divided by cross-hatched engraved brackets and two opposed curvilinear engraved lines (Figure 49). The upper horizontal engraved line of the panel has downward-pointing excised tick marks, and the panel itself has a single horizontal and curvilinear scroll line with downward-pointing excised tick marks (Figure 49).

PIGMENT USE AND LOCATION ON VESSEL: red pigment in engraved lines

TYPE AND VARIETY (IF KNOWN): Simms Engraved 
SITE NAME OR SITE NUMBER: Goode Hunt

VESSEL NO.: 59, Burial I-7

VESSEL FORM: Carinated bowl

NON-PLASTICS AND PASTE: bone

RIM AND LIP FORM: Inverted rim and rounded lip; lip notched

CORE COLOR: B (fired and cooled in a reducing environment)

INTERIOR SURFACE COLOR: black

EXTERIOR SURFACE COLOR: black

WALL THICKNESS (IN MM): rim, $4.0 \mathrm{~mm}$

INTERIOR SURFACE TREATMENT: burnished

EXTERIOR SURFACE TREATMENT: burnished

HEIGHT (IN CM): 4.8

ORIFICE DIAMETER (IN CM): 7.2

DIAMETER AT BOTTOM OF RIM OR NECK (IN CM): 9.1

BASE DIAMETER (IN CM) AND SHAPE OF BASE: 4.3; circular and rounded

ESTIMATED VOLUME (IN LITERS): 0.2
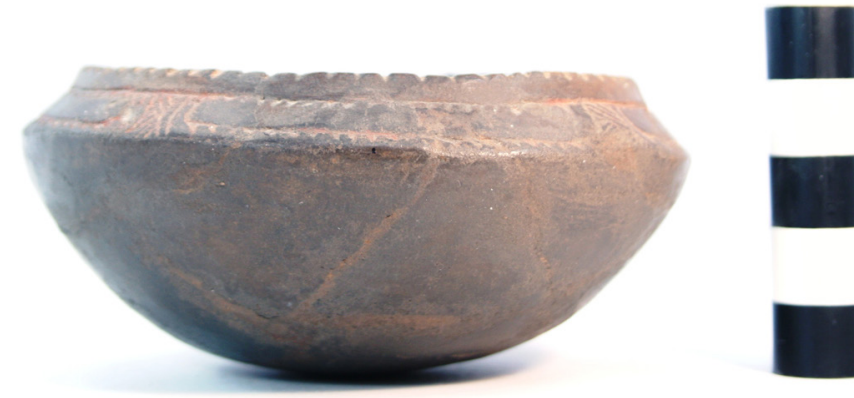

Figure 50. Simms Engraved carinated bowl (Vessel No. 59) in Burial I-7 at the Goode Hunt site.

DECORATION (INCLUDING MOTIF AND ELEMENTS WHEN APPARENT): The rim of the vessel is divided into four panels divided by opposed hatched engraved brackets (Figure 50). The upper horizontal engraved line of the panel has downward-pointing excised tick marks, and the panel itself has a single horizontal and curvilinear scroll line with downward-pointing excised tick marks (Figure 50).

PIGMENT USE AND LOCATION ON VESSEL: red pigment in the engraved lines

TYPE AND VARIETY (IF KNOWN): Simms Engraved 
SITE NAME OR SITE NUMBER: Goode Hunt

VESSEL NO.: 60, Burial I-7

VESSEL FORM: Jar

NON-PLASTICS AND PASTE: grog and bone

RIM AND LIP FORM: Everted rim and rounded, exterior folded lip

CORE COLOR: $\mathrm{G}$ (fired in a reducing environment and cooled in the open air)

INTERIOR SURFACE COLOR: dark grayishbrown

EXTERIOR SURFACE COLOR: dark yellowishbrown; fire clouds on the rim, body, and base; organic residue on the body

WALL THICKNESS (IN MM): rim, 7.6 mm

INTERIOR SURFACE TREATMENT: smoothed

EXTERIOR SURFACE TREATMENT: smoothed on the body

HEIGHT (IN CM): 16.4

ORIFICE DIAMETER (IN CM): 15.4

DIAMETER AT BOTTOM OF RIM OR NECK (IN CM): 14.2

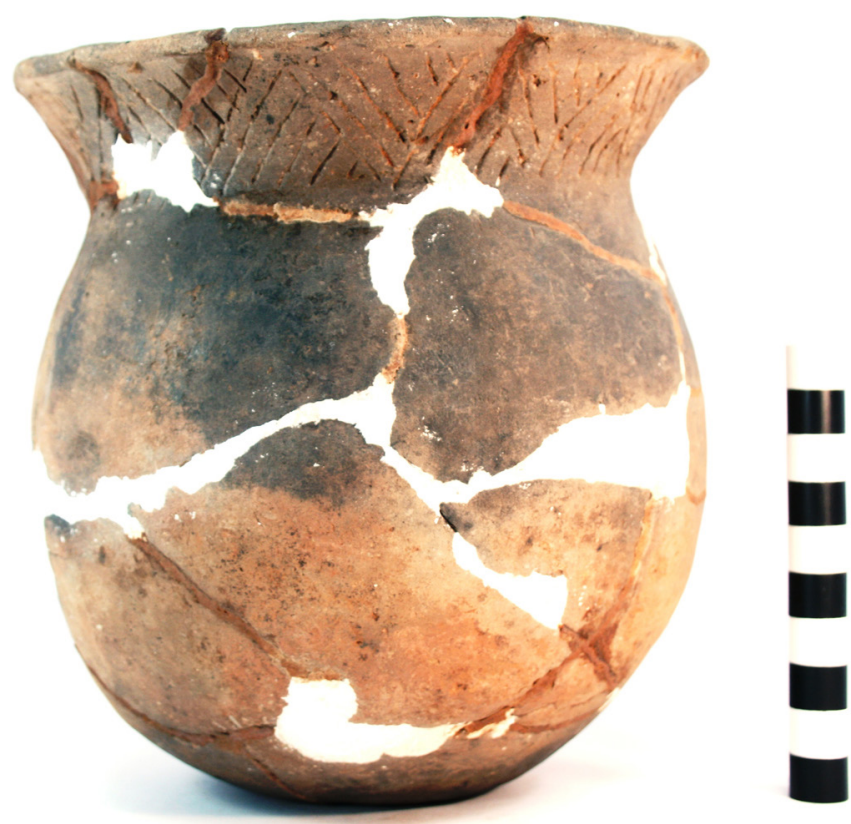

Figure 51. Maydelle Incised jar (Vessel No. 60) in Burial I-7 at the Goode Hunt site.

BASE DIAMETER (IN CM) AND SHAPE OF BASE: 5.1; circular and rounded

ESTIMATED VOLUME (IN LITERS): 2.2

DECORATION (INCLUDING MOTIF AND ELEMENTS WHEN APPARENT): The rim of the vessel has at least nine diagonal opposed incised triangle elements (Figure 51).

PIGMENT USE AND LOCATION ON VESSEL: none

TYPE AND VARIETY (IF KNOWN): Maydelle Incised 
SITE NAME OR SITE NUMBER: Goode Hunt

VESSEL NO.: 63a, Burial I-8

VESSEL FORM: Jar with a short rim

NON-PLASTICS AND PASTE: grog

RIM AND LIP FORM: Everted rim and rounded lip

CORE COLOR: F (fired in a reducing environment and cooled in the open air)

INTERIOR SURFACE COLOR: dark yellowishbrown; fire clouds on the rim, body, and base

EXTERIOR SURFACE COLOR: dark yellowishbrown; fire clouds on the rim, body, and base

WALL THICKNESS (IN MM): rim, $5.6 \mathrm{~mm}$

INTERIOR SURFACE TREATMENT: smoothed

EXTERIOR SURFACE TREATMENT: none

HEIGHT (IN CM): 10.3

ORIFICE DIAMETER (IN CM): 11.4

DIAMETER AT BOTTOM OF RIM OR NECK (IN CM): 9.7

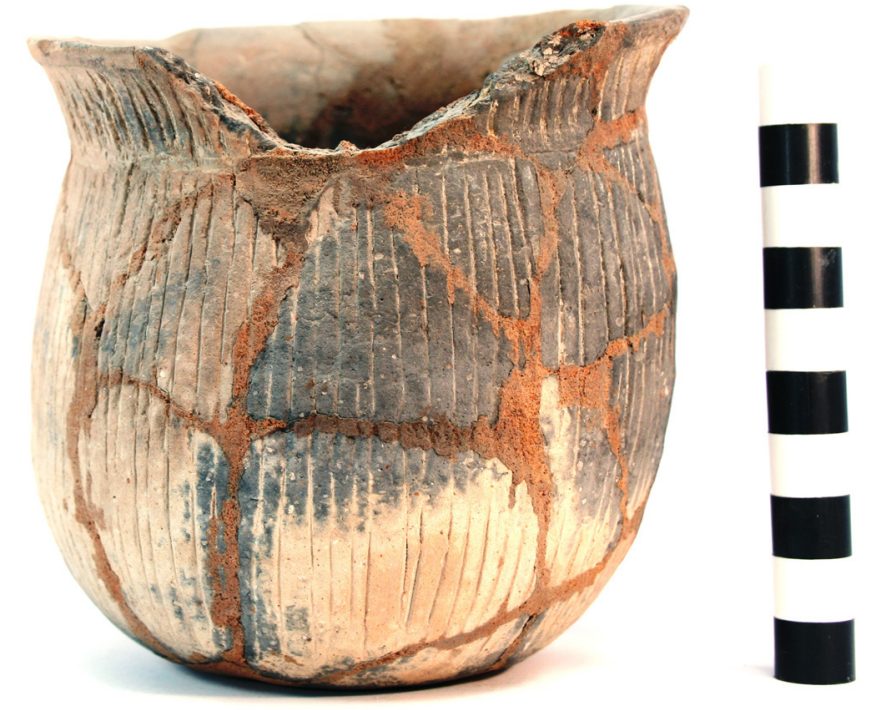

Figure 52. Karnack Brushed-Incised jar (Vessel No. 63a) in Burial I-8 at the Goode Hunt site.

BASE DIAMETER (IN CM) AND SHAPE OF

BASE: 5.7; circular and flat

ESTIMATED VOLUME (IN LITERS): 0.7

DECORATION (INCLUDING MOTIF AND ELEMENTS WHEN APPARENT): The rim and body of the vessel have a continuous series of vertical incised lines that extend from the rim to within $1.5 \mathrm{~cm}$ of the vessel base (Figure 52).

PIGMENT USE AND LOCATION ON VESSEL: none

TYPE AND VARIETY (IF KNOWN): Karnack Brushed-Incised 
SITE NAME OR SITE NUMBER: Goode Hunt

VESSEL NO.: 63b, Burial I-8

VESSEL FORM: Jar

NON-PLASTICS AND PASTE: grog

RIM AND LIP FORM: Everted rim and rounded lip

CORE COLOR: $\mathrm{G}$ (fired in a reducing environment and cooled in the open air)

INTERIOR SURFACE COLOR: dark grayish-brown

EXTERIOR SURFACE COLOR: dark yellowishbrown; fire clouds on the rim and body; organic residue on the rim and body

WALL THICKNESS (IN MM): rim, $4.7 \mathrm{~mm}$

INTERIOR SURFACE TREATMENT: smoothed

EXTERIOR SURFACE TREATMENT: smoothed on the body

HEIGHT (IN CM): 12.1

ORIFICE DIAMETER (IN CM): 10.8

DIAMETER AT BOTTOM OF RIM OR NECK (IN CM): 9.1

BASE DIAMETER (IN CM) AND SHAPE OF

BASE: 5.1; circular and flat

ESTIMATED VOLUME (IN LITERS): 0.78

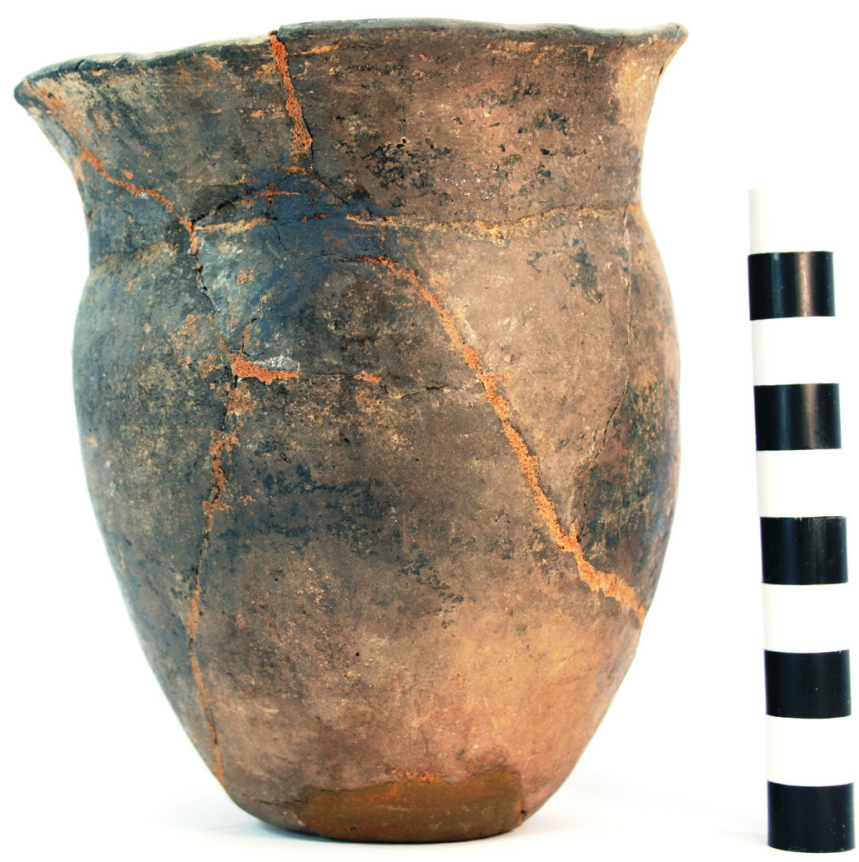

Figure 53. Plain jar (Vessel No. 63b) in Burial I-8 at the Goode Hunt site.

DECORATION (INCLUDING MOTIF AND ELEMENTS WHEN APPARENT): Plain (Figure 53)

PIGMENT USE AND LOCATION ON VESSEL: none

TYPE AND VARIETY (IF KNOWN): Unidentified plain ware 
SITE NAME OR SITE NUMBER: Goode Hunt

VESSEL NO.: 64, Burial I-8

VESSEL FORM: Carinated bowl

NON-PLASTICS AND PASTE: grog

RIM AND LIP FORM: inverted rim and rounded lip

CORE COLOR: F (fired in a reducing environment and cooled in the open air)

INTERIOR SURFACE COLOR: dark reddish-brown; fire clouds on the body

EXTERIOR SURFACE COLOR: dark reddish-brown; fire clouds on the rim, body, and base

WALL THICKNESS (IN MM): $\operatorname{rim}, 5.8 \mathrm{~mm}$

INTERIOR SURFACE TREATMENT: smoothed

EXTERIOR SURFACE TREATMENT: smoothed

HEIGHT (IN CM): 4.3

ORIFICE DIAMETER (IN CM): 10.0

DIAMETER AT BOTTOM OF RIM OR NECK

(IN CM): 10.7

BASE DIAMETER (IN CM) AND SHAPE OF

BASE: 4.4; circular and rounded

ESTIMATED VOLUME (IN LITERS): 0.26

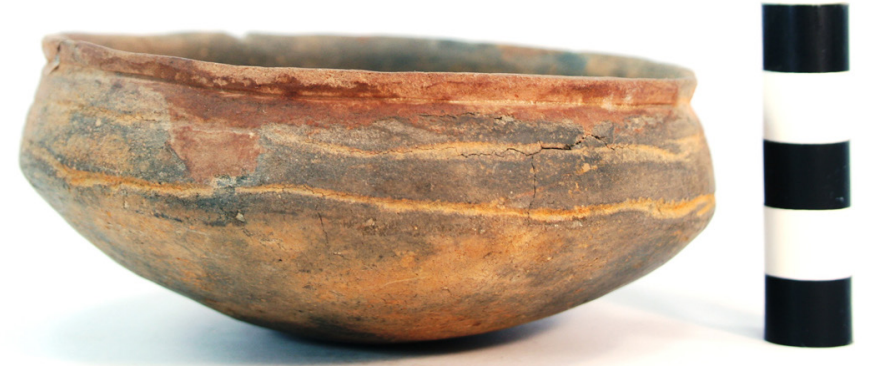

Figure 54. Engraved carinated bowl (Vessel No. 64) in Burial I-8 at the Goode Hunt site.

DECORATION (INCLUDING MOTIF AND ELEMENTS WHEN APPARENT): The rim has three widely-spaced horizontal engraved lines (Figure 54).

PIGMENT USE AND LOCATION ON VESSEL: none

TYPE AND VARIETY (IF KNOWN): Unidentified fine ware 
SITE NAME OR SITE NUMBER: Goode Hunt

VESSEL NO.: 65, Burial I-9

VESSEL FORM: Bottle with a spool neck

NON-PLASTICS AND PASTE: grog

RIM AND LIP FORM: Everted rim and rounded lip

CORE COLOR: $\mathrm{G}$ (fired in a reducing environment and cooled in the open air)

INTERIOR SURFACE COLOR: dark grayishbrown

EXTERIOR SURFACE COLOR: reddish-brown

WALL THICKNESS (IN MM): rim, $5.0 \mathrm{~mm}$

INTERIOR SURFACE TREATMENT: none

EXTERIOR SURFACE TREATMENT: burnished

HEIGHT (IN CM): 11.7

ORIFICE DIAMETER (IN CM): 4.4

DIAMETER AT BOTTOM OF RIM OR NECK

(IN CM): 4.1 ; maximum body diameter of $10.5 \mathrm{~cm}$

BASE DIAMETER (IN CM) AND SHAPE OF

BASE: 4.5; circular and flat

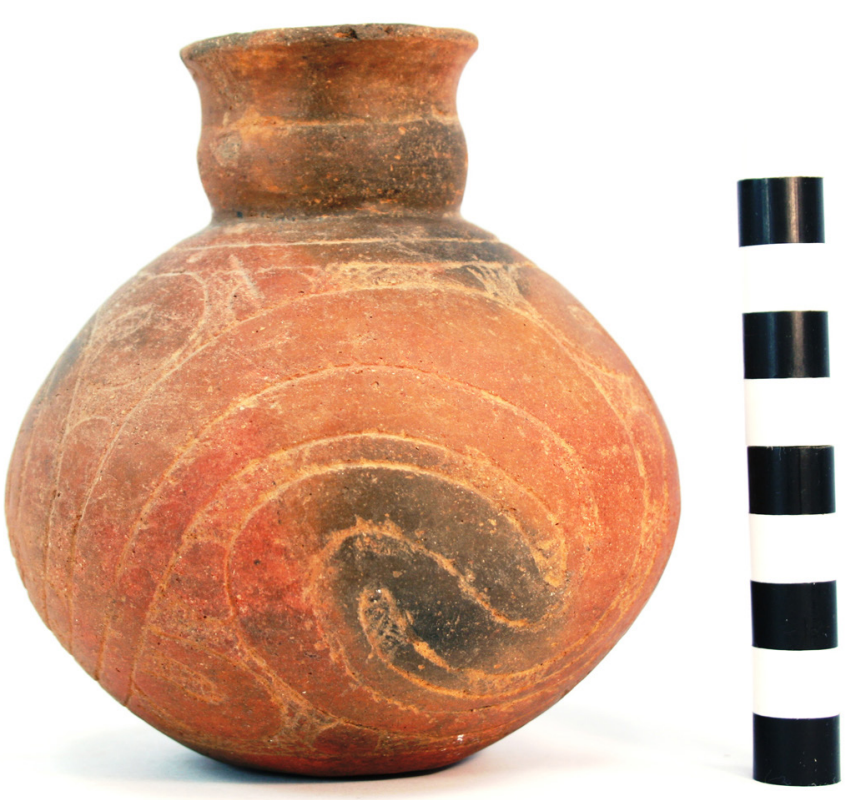

Figure 55. Hodges Engraved bottle (Vessel No. 65) in Burial I-9 at the Goode Hunt site.

\section{ESTIMATED VOLUME (IN LITERS): 0.21}

DECORATION (INCLUDING MOTIF AND ELEMENTS WHEN APPARENT): The vessel body has a meandering engraved scroll line with excised tick marks (Figure 55). The three upper and lower triangular to curvilinear-shaped scroll fill zones have excised brackets and excised areas that have formed negative ovals and rectangles. There are also cross-hatched engraved areas in the upper scroll fill zones.

PIGMENT USE AND LOCATION ON VESSEL: none

TYPE AND VARIETY (IF KNOWN): Hodges Engraved 
SITE NAME OR SITE NUMBER: Goode Hunt

VESSEL NO.: 66, Burial I-9

VESSEL FORM: Globular Carinated bowl

NON-PLASTICS AND PASTE: grog

RIM AND LIP FORM: Direct rim and rounded, exterior folded lip

CORE COLOR: F (fired in a reducing environment and cooled in the open air)

INTERIOR SURFACE COLOR: yellowish-brown; fire clouds on the rim

EXTERIOR SURFACE COLOR: yellowish-brown; fire clouds on the rim, body, and base

WALL THICKNESS (IN MM): $\operatorname{rim}, 5.8 \mathrm{~mm}$

INTERIOR SURFACE TREATMENT: burnished

EXTERIOR SURFACE TREATMENT: burnished

HEIGHT (IN CM): 7.7

ORIFICE DIAMETER (IN CM): 14.8

DIAMETER AT BOTTOM OF RIM OR NECK

(IN CM): 14.6

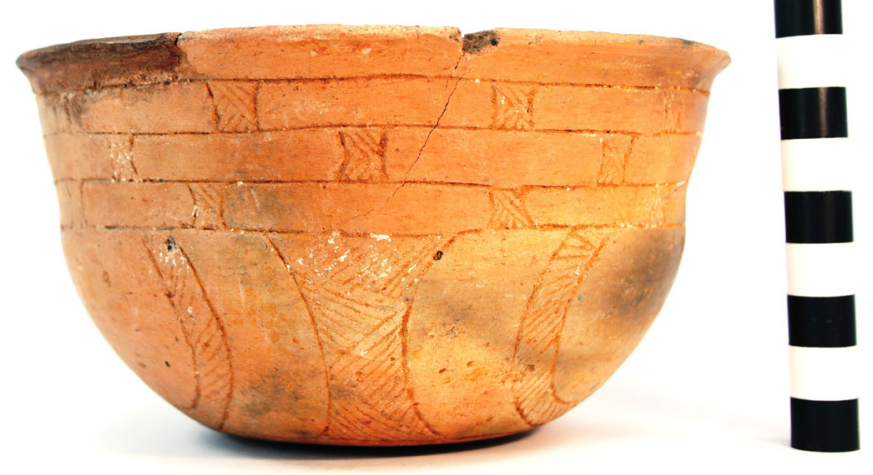

Figure 56. Engraved carinated bowl (Vessel No. 66) in Burial I-9 at the Goode Hunt site.

BASE DIAMETER (IN CM) AND SHAPE OF BASE: 7.6; circular and flat

ESTIMATED VOLUME (IN LITERS): 0.7

DECORATION (INCLUDING MOTIF AND ELEMENTS WHEN APPARENT): The vessel rim has three stacked horizontal engraved panels that have nine internal columns per panel (Figure 56). These columns are filled with diagonal opposed hatched lines. The vessel body has three large semi-circular zones that are filled with diagonal hatched lines (Figure 56). The semi-circular zones are divided by three large engraved brackets filled with sets of diagonal opposed hatched lines. There is also a single horizontal engraved line on the interior vessel surface at the carination.

The engraved design on this vessel resembles in several respects (i.e., flattened ovals or panels on the rim and repeated semi-circles on the body) the engraved motifs on Cabaness Engraved vessels found at the Cedar Grove (3LA97), Battle (3LA1), and Hatchel (41BW3) sites in the Great Bend area along the Red River (Schambach and Miller 1984:120 and Figure 11-23a-b). According to Schambach and Miller (1984:120), Cabaness Engraved vessels appear to be a ceramic diagnostic of the Historic Caddo period Chakanina phase.

PIGMENT USE AND LOCATION ON VESSEL: white pigment in engraved lines

TYPE AND VARIETY (IF KNOWN): Unidentified fine ware, cf. Cabaness Engraved 
SITE NAME OR SITE NUMBER: Goode Hunt

VESSEL NO.: 68, Burial I-9

VESSEL FORM: Jar

NON-PLASTICS AND PASTE: grog

RIM AND LIP FORM: Everted rim and rounded lip

CORE COLOR: G (fired in a reducing environment and cooled in the open air)

INTERIOR SURFACE COLOR: dark grayish-brown; organic residue on the rim and body

EXTERIOR SURFACE COLOR: yellowish-brown; fire clouds on the rim, body, and base; organic residue on the body

WALL THICKNESS (IN MM): rim, 7.2 mm

INTERIOR SURFACE TREATMENT: smoothed

EXTERIOR SURFACE TREATMENT: smoothed on the body

HEIGHT (IN CM): 15.9

ORIFICE DIAMETER (IN CM): 14.4

DIAMETER AT BOTTOM OF RIM OR NECK (IN CM): 13.3

BASE DIAMETER (IN CM) AND SHAPE OF

BASE: 6.0; circular and flat

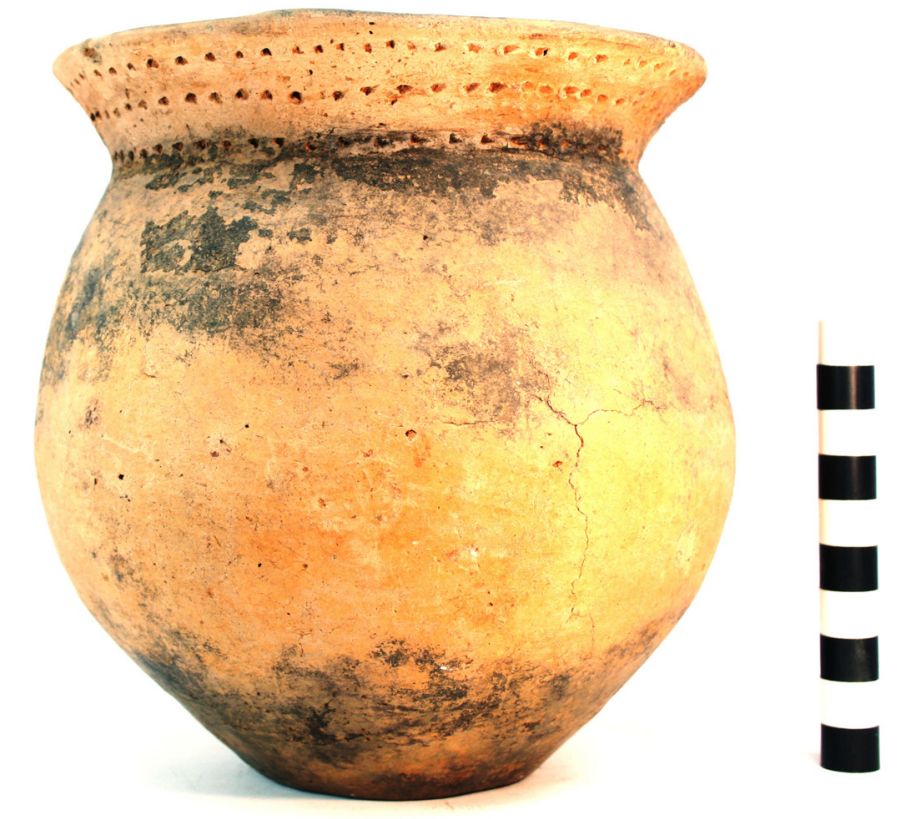

Figure 57. Mockingbird Punctated jar (Vessel No. 68) in Burial I-9 at the Goode Hunt site.

ESTIMATED VOLUME (IN LITERS): 1.4

DECORATION (INCLUDING MOTIF AND ELEMENTS WHEN APPARENT): There are three horizontal rows of tool punctations on the vessel rim (Figure 57).

PIGMENT USE AND LOCATION ON VESSEL: none

TYPE AND VARIETY (IF KNOWN): Mockingbird Punctated 
SITE NAME OR SITE NUMBER: Goode Hunt

VESSEL NO.: 69, Burial I-9

VESSEL FORM: Jar

NON-PLASTICS AND PASTE: grog

RIM AND LIP FORM: Everted rim; the lip is missing

CORE COLOR: G (fired in a reducing environment and cooled in the open air)

INTERIOR SURFACE COLOR: dark grayish-brown

EXTERIOR SURFACE COLOR: yellowish-brown; fire clouds on the rim, body, and base; organic residue on the body

WALL THICKNESS (IN MM): rim, $7.6 \mathrm{~mm}$; body, $8.8 \mathrm{~mm}$

INTERIOR SURFACE TREATMENT: smoothed

EXTERIOR SURFACE TREATMENT: smoothed on the body

HEIGHT (IN CM): 22.7+

ORIFICE DIAMETER (IN CM): 17.8+

DIAMETER AT BOTTOM OF RIM OR NECK (IN CM): 18.4

BASE DIAMETER (IN CM) AND SHAPE OF

BASE: 6.4 ; circular and flat

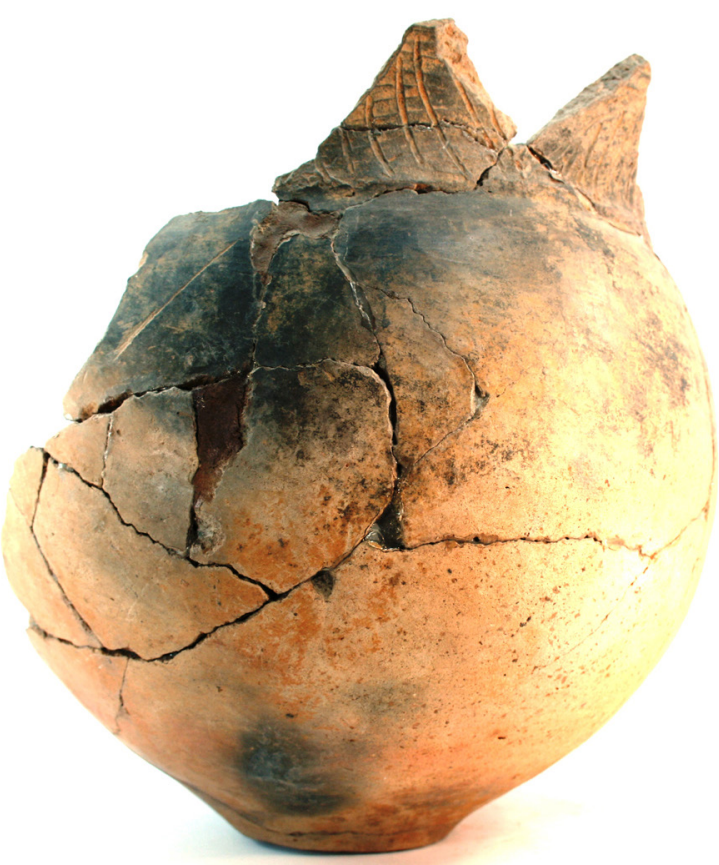

Figure 58. Maydelle Incised jar (Vessel No. 69) in Burial I-9 at the Goode Hunt site.

ESTIMATED VOLUME (IN LITERS): $3.6+$

DECORATION (INCLUDING MOTIF AND ELEMENTS WHEN APPARENT): The rim has an unknown number of incised triangles filled with diagonal opposed incised lines (Figure 58).

PIGMENT USE AND LOCATION ON VESSEL: none

TYPE AND VARIETY (IF KNOWN): Maydelle Incised 
SITE NAME OR SITE NUMBER: Goode Hunt

VESSEL NO.: 75, Burial I-10

VESSEL FORM: Jar

NON-PLASTICS AND PASTE: grog

RIM AND LIP FORM: Everted rim and rounded lip

CORE COLOR: B (fired and cooled in a reducing environment)

INTERIOR SURFACE COLOR: very dark gray

EXTERIOR SURFACE COLOR: very dark gray; fire clouds on the rim and body; organic residue on the body

WALL THICKNESS (IN MM): rim, $8.2 \mathrm{~mm}$

INTERIOR SURFACE TREATMENT: smoothed

EXTERIOR SURFACE TREATMENT: smoothed

HEIGHT (IN CM): 9.3

ORIFICE DIAMETER (IN CM): 9.5

DIAMETER AT BOTTOM OF RIM OR NECK (IN CM): 8.1

BASE DIAMETER (IN CM) AND SHAPE OF

BASE: 5.7; circular and flat

ESTIMATED VOLUME (IN LITERS): 0.53

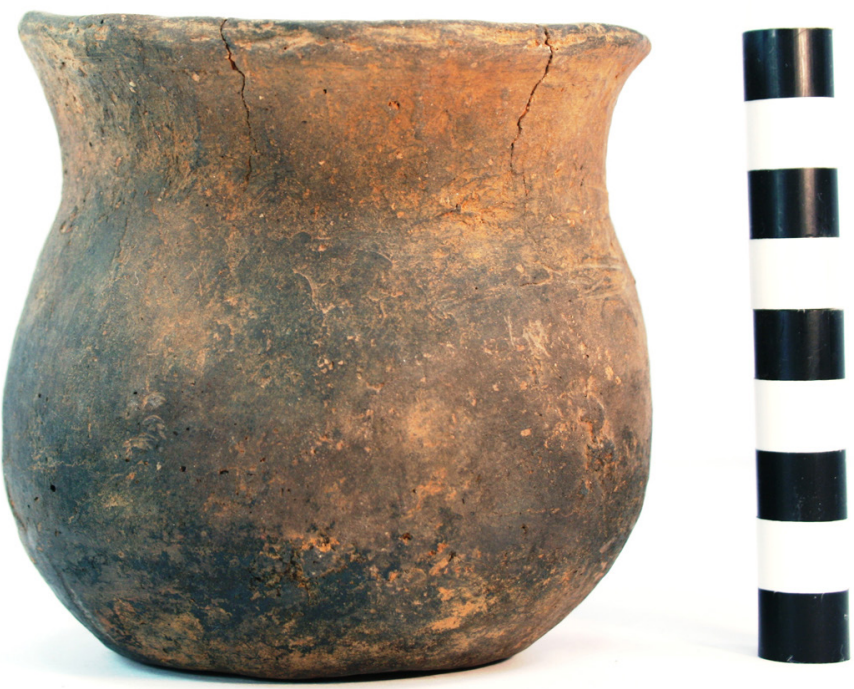

Figure 59. Plain jar (Vessel No. 75) in Burial I-10 at the Goode Hunt site.

DECORATION (INCLUDING MOTIF AND ELEMENTS WHEN APPARENT): Plain (Figure 59)

PIGMENT USE AND LOCATION ON VESSEL: none

TYPE AND VARIETY (IF KNOWN): Unidentified plain ware 
SITE NAME OR SITE NUMBER: Goode Hunt

VESSEL NO.: 76, Burial I-11

VESSEL FORM: Jar

NON-PLASTICS AND PASTE: grog

RIM AND LIP FORM: Everted rim and rounded lip

CORE COLOR: $\mathrm{F}$ (fired in a reducing environment and cooled in the open air)

INTERIOR SURFACE COLOR: dark reddish-brown; fire clouds on the rim

EXTERIOR SURFACE COLOR: brown; fire clouds on the rim, body, and base

WALL THICKNESS (IN MM): rim, 4.4 mm

INTERIOR SURFACE TREATMENT: none

EXTERIOR SURFACE TREATMENT: smoothed on the body

HEIGHT (IN CM): 10.2

ORIFICE DIAMETER (IN CM): 11.5

DIAMETER AT BOTTOM OF RIM OR NECK (IN CM): 10.8

BASE DIAMETER (IN CM) AND SHAPE OF BASE: 4.6; circular and flat

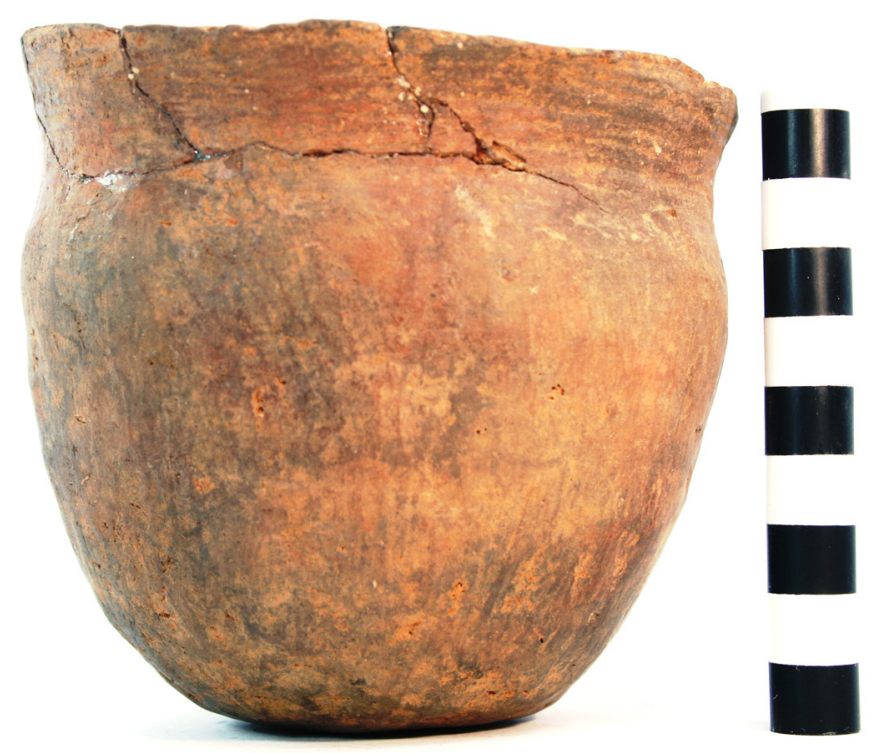

Figure 60. Brushed jar (Vessel No. 76) in Burial I-11 at the Goode Hunt site.

ESTIMATED VOLUME (IN LITERS): 0.7

DECORATION (INCLUDING MOTIF AND ELEMENTS WHEN APPARENT): There are horizontal brushing marks on the vessel rim (Figure 60).

PIGMENT USE AND LOCATION ON VESSEL: none

TYPE AND VARIETY (IF KNOWN): Unidentified utility ware 
SITE NAME OR SITE NUMBER: Goode Hunt

VESSEL NO.: 77, Burial I-11

VESSEL FORM: Bottle

NON-PLASTICS AND PASTE: grog

RIM AND LIP FORM: Everted rim and rounded lip

CORE COLOR: $\mathrm{G}$ (fired in a reducing environment and cooled in the open air)

INTERIOR SURFACE COLOR: dark grayish-brown

EXTERIOR SURFACE COLOR: dark yellowishbrown; fire clouds on the body and base

WALL THICKNESS (IN MM): rim, $6.1 \mathrm{~mm}$

INTERIOR SURFACE TREATMENT: none

EXTERIOR SURFACE TREATMENT: none

HEIGHT (IN CM): 9.3

ORIFICE DIAMETER (IN CM): 3.3

DIAMETER AT BOTTOM OF RIM OR NECK (IN CM): 3.9 ; maximum body diameter is $8.3 \mathrm{~cm}$

BASE DIAMETER (IN CM) AND SHAPE OF BASE: 5.1; circular and flat

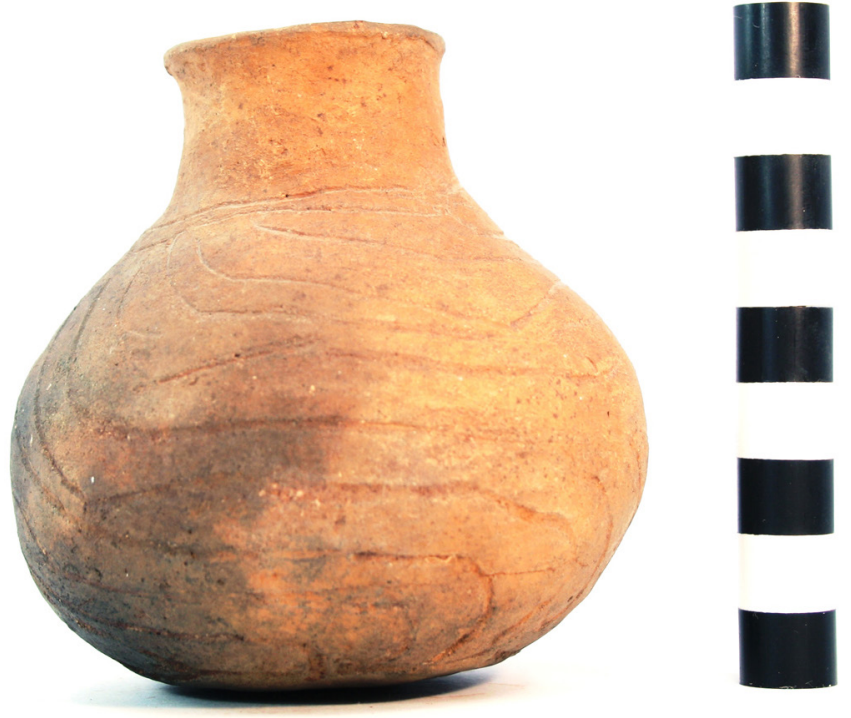

Figure 61. cf. Keno Trailed bottle (Vessel No. 77) in Burial I-11 at the Goode Hunt site.

ESTIMATED VOLUME (IN LITERS): 0.19

DECORATION (INCLUDING MOTIF AND ELEMENTS WHEN APPARENT): The vessel body has two horizontal trailed lines below the bottle neck as well as a continuous series of diagonal and curvilinear trailed lines that encircle the vessel (Figure 61). There are also two hooked arm elements on the lower part of the vessel body.

PIGMENT USE AND LOCATION ON VESSEL: none

TYPE AND VARIETY (IF KNOWN): cf. Keno Trailed 
SITE NAME OR SITE NUMBER: Goode Hunt

VESSEL NO.: 78, Burial I-11

VESSEL FORM: Carinated bowl

NON-PLASTICS AND PASTE: grog

RIM AND LIP FORM: Direct rim and a rounded, exterior folded lip; lip notched

CORE COLOR: A (fired and cooled in an oxidizing environment)

INTERIOR SURFACE COLOR: reddish-brown

EXTERIOR SURFACE COLOR: reddish-brown; fire clouds on the body and base

WALL THICKNESS (IN MM): rim, $5.1 \mathrm{~mm}$

INTERIOR SURFACE TREATMENT: smoothed

EXTERIOR SURFACE TREATMENT: burnished

HEIGHT (IN CM): 4.3

ORIFICE DIAMETER (IN CM): 12.1

DIAMETER AT BOTTOM OF RIM OR NECK

(IN CM): 11.5

BASE DIAMETER (IN CM) AND SHAPE OF

BASE: 3.7; circular and flat

Figure 62. cf. Simms Engraved carinated bowl (Vessel

ESTIMATED VOLUME (IN LITERS): 0.31

No. 78) in Burial I-11 at the Goode Hunt site.

DECORATION (INCLUDING MOTIF AND ELEMENTS WHEN APPARENT): The vessel has a series of eight engraved triangular elements that are filled with vertical hatched lines (Figure 62). Five of the triangular elements have their apex pointing towards the carination and the other three have their apex pointing towards the vessel lip.

PIGMENT USE AND LOCATION ON VESSEL: none

TYPE AND VARIETY (IF KNOWN): cf. Simms Engraved 
SITE NAME OR SITE NUMBER: Goode Hunt

VESSEL NO.: 79, Burial I-12

VESSEL FORM: Compound bowl with rim peaks; two opposed suspension holes (1.8 $\mathrm{mm}$ in diameter) on the rim (Figure 63)

NON-PLASTICS AND PASTE: grog

RIM AND LIP FORM: Everted rim and rounded lip

CORE COLOR: $\mathrm{G}$ (fired in a reducing environment and cooled in the open air)

INTERIOR SURFACE COLOR: very dark gray; fire clouds on the rim

EXTERIOR SURFACE COLOR: reddish-brown; fire clouds on the rim and body

WALL THICKNESS (IN MM): rim, $4.5 \mathrm{~mm}$

INTERIOR SURFACE TREATMENT: smoothed

EXTERIOR SURFACE TREATMENT: smoothed

HEIGHT (IN CM): 5.7

ORIFICE DIAMETER (IN CM): 10.2

DIAMETER AT BOTTOM OF RIM OR NECK

(IN CM): 8.9

BASE DIAMETER (IN CM) AND SHAPE OF

BASE: 3.7; circular and rounded

ESTIMATED VOLUME (IN LITERS): 0.46
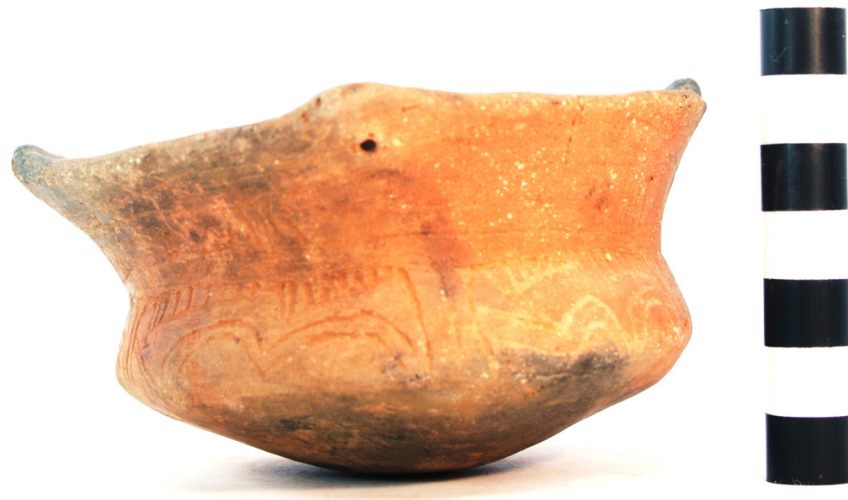

Figure 63. Engraved compound bowl (Vessel No. 79) in Burial I-12 at the Goode Hunt site.

DECORATION (INCLUDING MOTIF AND ELEMENTS WHEN APPARENT): The upper panel of the vessel has three horizontal engraved lines; between the bottom two lines are widely-spaced sets of three vertical engraved lines (Figure 63). The lower panel has been divided into six sections by vertical engraved brackets. One of these sections has a large upper triangular element filled with hatched lines and two lower small triangles filled with hatched lines. The other five sections have two upper triangular elements filled with hatched lines and two lower concentric semi-circles (Figure 63). There is also in the five sections a set of three diagonal engraved lines that originate on one side of one of the concentric semi-circles.

PIGMENT USE AND LOCATION ON VESSEL: none

TYPE AND VARIETY (IF KNOWN): Unidentified fine ware 
SITE NAME OR SITE NUMBER: Goode Hunt

VESSEL NO.: 80, Burial I-12

VESSEL FORM: Jar

NON-PLASTICS AND PASTE: grog and bone

RIM AND LIP FORM: Everted rim and rounded lip

CORE COLOR: $\mathrm{F}$ (fired in a reducing environment and cooled in the open air)

INTERIOR SURFACE COLOR: reddish-brown; fire clouds on the rim

EXTERIOR SURFACE COLOR: reddish-brown; fire clouds on the rim, body, and base

WALL THICKNESS (IN MM): rim, $5.3 \mathrm{~mm}$

INTERIOR SURFACE TREATMENT: smoothed

EXTERIOR SURFACE TREATMENT: none

HEIGHT (IN CM): 8.9

ORIFICE DIAMETER (IN CM): 10.2

DIAMETER AT BOTTOM OF RIM OR NECK

(IN CM): 8.6

BASE DIAMETER (IN CM) AND SHAPE OF

BASE: 5.1; circular and flat

ESTIMATED VOLUME (IN LITERS): 0.55

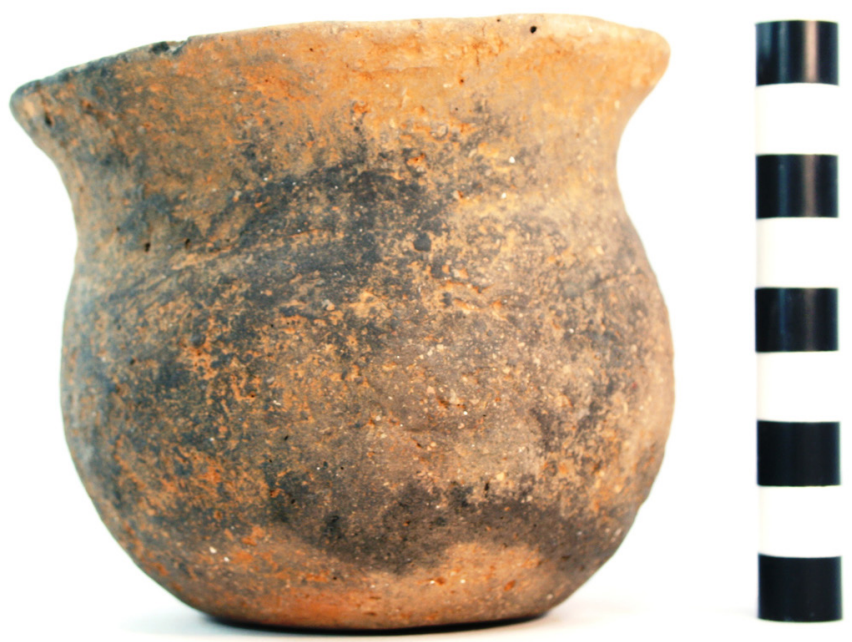

Figure 64. Plain jar (Vessel No. 80) in Burial I-12 at the Goode Hunt site.

DECORATION (INCLUDING MOTIF AND ELEMENTS WHEN APPARENT): Plain (Figure 64)

PIGMENT USE AND LOCATION ON VESSEL: none

TYPE AND VARIETY (IF KNOWN): Unidentified plain ware 
SITE NAME OR SITE NUMBER: Goode Hunt

VESSEL NO.: 81, Burial I-13

VESSEL FORM: Jar

NON-PLASTICS AND PASTE: grog

RIM AND LIP FORM: Everted rim and rounded lip

CORE COLOR: F (fired in a reducing environment and cooled in the open air)

INTERIOR SURFACE COLOR: dark reddish-brown; fire clouds on the rim, body, and base

EXTERIOR SURFACE COLOR: dark yellowishbrown; fire clouds on the rim, body, and base; organic residue on the rim and body

WALL THICKNESS (IN MM): rim, $4.6 \mathrm{~mm}$

INTERIOR SURFACE TREATMENT: smoothed

EXTERIOR SURFACE TREATMENT: none

HEIGHT (IN CM): 10.9

ORIFICE DIAMETER (IN CM): 8.9

DIAMETER AT BOTTOM OF RIM OR NECK (IN CM): 7.2

BASE DIAMETER (IN CM) AND SHAPE OF

BASE: 5.1; circular and flat

ESTIMATED VOLUME (IN LITERS): 0.58

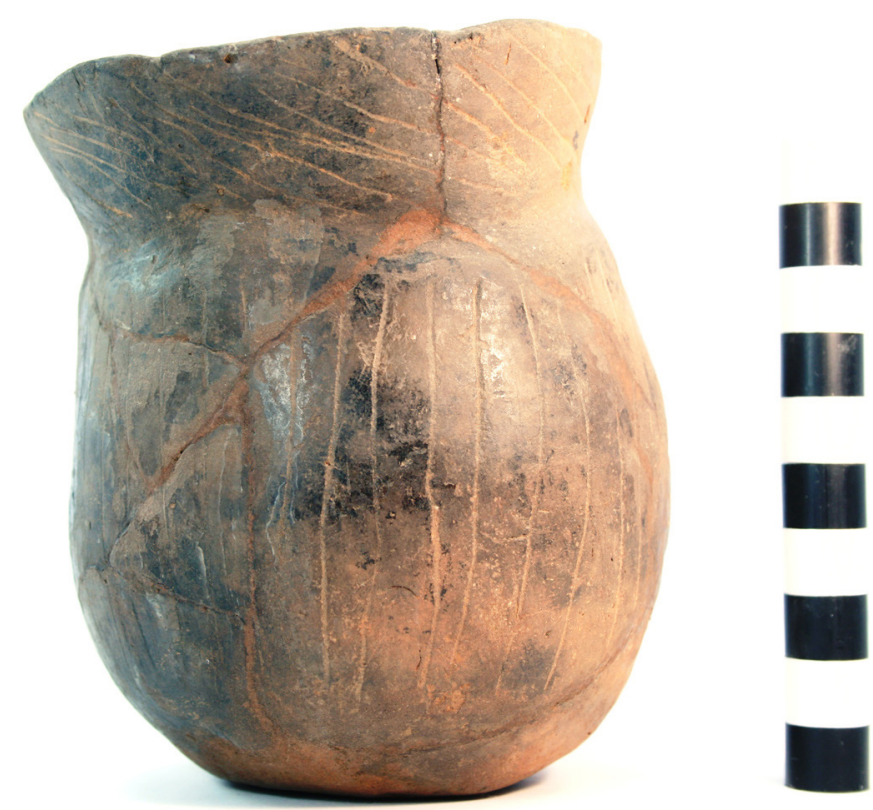

Figure 65. Incised jar (Vessel No. 81) in Burial I-13 at the Goode Hunt site.

DECORATION (INCLUDING MOTIF AND ELEMENTS WHEN APPARENT): The vessel rim has a continuous series of left to right diagonal incised lines (Figure 65). The vessel body has a continuous series of vertical incised lines from the rim-body juncture to within $1.5 \mathrm{~cm}$ of the vessel base.

PIGMENT USE AND LOCATION ON VESSEL: none

TYPE AND VARIETY (IF KNOWN): Unidentified utility ware 
SITE NAME OR SITE NUMBER: Goode Hunt

VESSEL NO.: 82, Burial I-14

VESSEL FORM: Jar

NON-PLASTICS AND PASTE: grog

RIM AND LIP FORM: Missing

CORE COLOR: F (fired in a reducing environment and cooled in the open air)

INTERIOR SURFACE COLOR: reddish-brown; fire clouds on the base

EXTERIOR SURFACE COLOR: dark yellowishbrown; fire clouds on the body and base

WALL THICKNESS (IN MM): body, $7.4 \mathrm{~mm}$

INTERIOR SURFACE TREATMENT: smoothed

EXTERIOR SURFACE TREATMENT: smoothed on lower body

HEIGHT (IN CM): 9.5+

ORIFICE DIAMETER (IN CM): 14.0+

DIAMETER AT BOTTOM OF RIM OR NECK

(IN CM): N/A

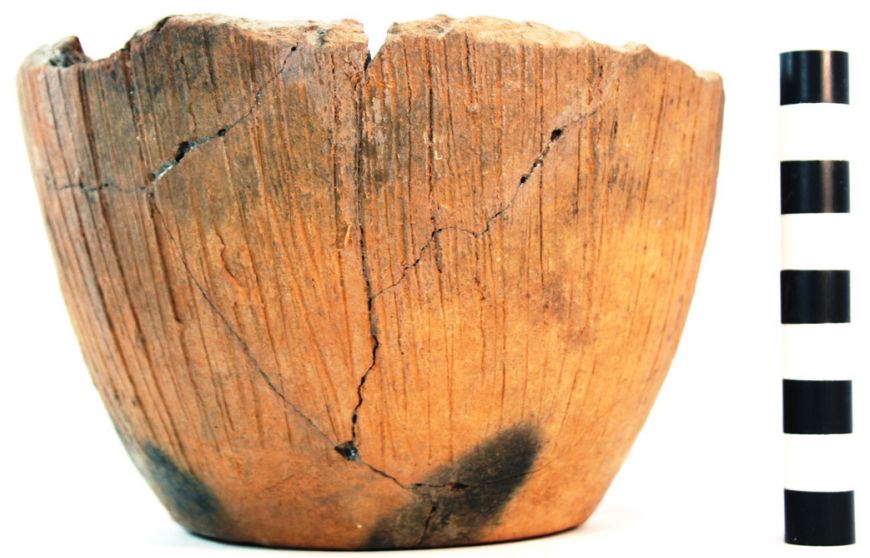

Figure 66. cf. Karnack Brushed-Incised jar (Vessel No. 82) in Burial I-14 at the Goode Hunt site.

BASE DIAMETER (IN CM) AND SHAPE OF BASE: 8.3; circular and flat

ESTIMATED VOLUME (IN LITERS): 0.8+

DECORATION (INCLUDING MOTIF AND ELEMENTS WHEN APPARENT): There are vertical brushed-incised marks and lines on the vessel body that extend to within $2.0 \mathrm{~cm}$ of the vessel base (Figure 66).

PIGMENT USE AND LOCATION ON VESSEL: none

TYPE AND VARIETY (IF KNOWN): cf. Karnack Brushed-Incised 
SITE NAME OR SITE NUMBER: Goode Hunt

VESSEL NO.: 83, Burial I-14

VESSEL FORM: Jar

NON-PLASTICS AND PASTE: grog

RIM AND LIP FORM: Everted rim and rounded lip

CORE COLOR: G (fired in a reducing environment and cooled in the open air)

INTERIOR SURFACE COLOR: dark grayishbrown

EXTERIOR SURFACE COLOR: reddish-brown; fire clouds on the body

WALL THICKNESS (IN MM): rim, 7.4 mm; body, $9.7 \mathrm{~mm}$

INTERIOR SURFACE TREATMENT: none

EXTERIOR SURFACE TREATMENT: none

HEIGHT (IN CM): $8.2+$

ORIFICE DIAMETER (IN CM): 9.0

DIAMETER AT BOTTOM OF RIM OR NECK (IN CM): 7.2

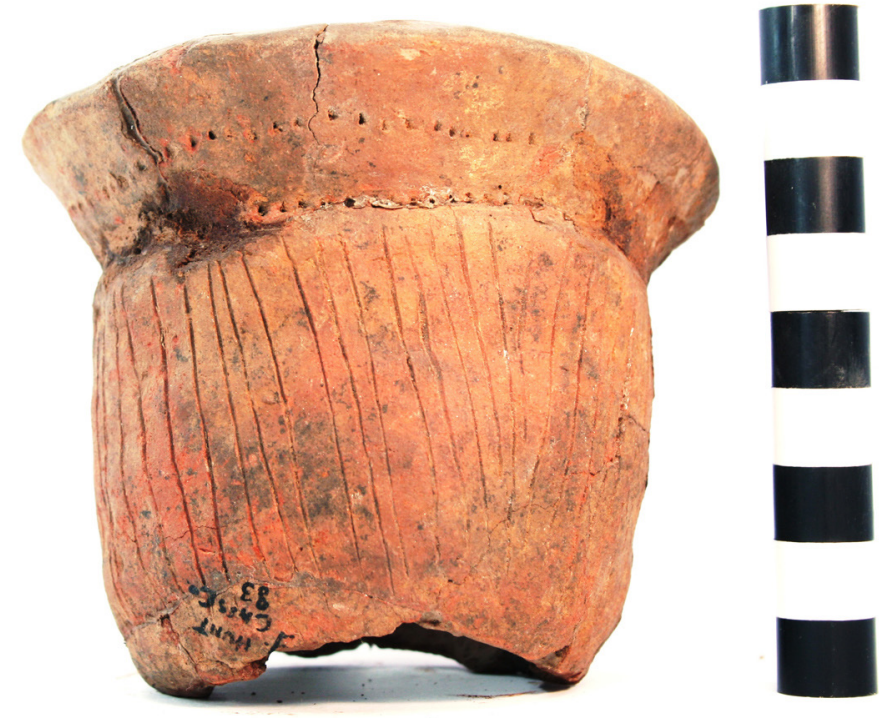

Figure 67. Incised-punctated jar (Vessel No. 83) in Burial I-14 at the Goode Hunt site.

BASE DIAMETER (IN CM) AND SHAPE OF BASE: missing

ESTIMATED VOLUME (IN LITERS): 0.45+

DECORATION (INCLUDING MOTIF AND ELEMENTS WHEN APPARENT): The vessel rim has two horizontal rows of small tool punctations. The vessel body has a continuous series of vertical incised lines (Figure 67).

PIGMENT USE AND LOCATION ON VESSEL: none

TYPE AND VARIETY (IF KNOWN): Unidentified utility ware 
SITE NAME OR SITE NUMBER: Goode Hunt

VESSEL NO.: 85, Burial I-14

VESSEL FORM: Bowl

NON-PLASTICS AND PASTE: grog

RIM AND LIP FORM: Direct rim and rounded lip; lip notched

CORE COLOR: $\mathrm{G}$ (fired in a reducing environment and cooled in the open air)

INTERIOR SURFACE COLOR: dark grayish-brown; fire clouds on the rim

EXTERIOR SURFACE COLOR: dark reddish-

brown; fire clouds on the body and base

WALL THICKNESS (IN MM): rim, $5.2 \mathrm{~mm}$

INTERIOR SURFACE TREATMENT: smoothed

EXTERIOR SURFACE TREATMENT: smoothed

HEIGHT (IN CM): 5.7

ORIFICE DIAMETER (IN CM): 8.9

DIAMETER AT BOTTOM OF RIM OR NECK

(IN CM): N/A

BASE DIAMETER (IN CM) AND SHAPE OF

BASE: 4.4; circular and flat

ESTIMATED VOLUME (IN LITERS): 0.2

Figure 68. Keno Trailed, var. Phillips bowl (Vessel No.

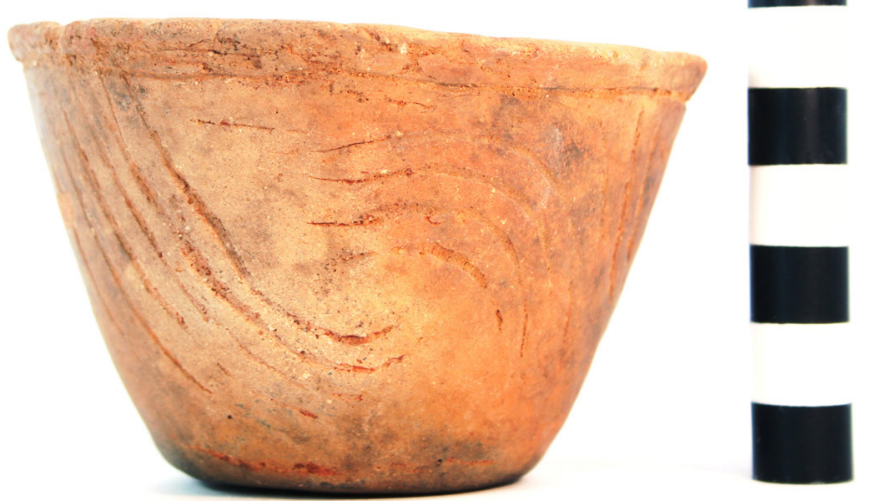

85) in Burial I-14 at the Goode Hunt site.

DECORATION (INCLUDING MOTIF AND ELEMENTS WHEN APPARENT): The vessel has a single horizontal trailed line under the vessel lip as well as three sets of upper and lower curvilinear trailed lines that hook around each other (Figure 68). The upper and lower sets have either three, four, or five curvilinear trailed lines per set.

PIGMENT USE AND LOCATION ON VESSEL: none

TYPE AND VARIETY (IF KNOWN): Keno Trailed, var. Phillips 
SITE NAME OR SITE NUMBER: Goode Hunt

VESSEL NO.: 86, Burial I-14

VESSEL FORM: Jar

NON-PLASTICS AND PASTE: grog

RIM AND LIP FORM: Everted rim and rounded lip

CORE COLOR: $\mathrm{F}$ (fired in a reducing environment and cooled in the open air)

INTERIOR SURFACE COLOR: reddish-brown;

fire clouds on the body and base

EXTERIOR SURFACE COLOR: reddish-brown; fire clouds on the body

WALL THICKNESS (IN MM): rim, $4.9 \mathrm{~mm}$

INTERIOR SURFACE TREATMENT: none

EXTERIOR SURFACE TREATMENT: none

HEIGHT (IN CM): 4.2

ORIFICE DIAMETER (IN CM): 5.8

DIAMETER AT BOTTOM OF RIM OR NECK (IN CM): 6.3

BASE DIAMETER (IN CM) AND SHAPE OF

BASE: 2.5; circular and rounded

ESTIMATED VOLUME (IN LITERS): 0.15

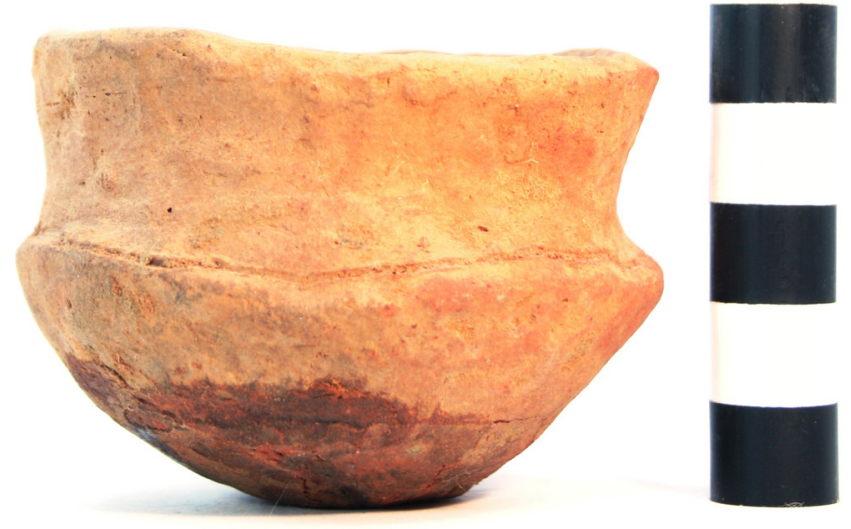

Figure 69. Incised jar (Vessel No. 86) in Burial I-14 at the Goode Hunt site.

DECORATION (INCLUDING MOTIF AND ELEMENTS WHEN APPARENT): There is a single horizontal line on the rim just above the rim-body juncture (Figure 69).

PIGMENT USE AND LOCATION ON VESSEL: none

TYPE AND VARIETY (IF KNOWN): Unidentified utility ware 
SITE NAME OR SITE NUMBER: Goode Hunt

VESSEL NO.: 87, Burial I-14

VESSEL FORM: Jar

NON-PLASTICS AND PASTE: shell

RIM AND LIP FORM: Everted rim and rounded lip

CORE COLOR: B (fired and cooled in a reducing environment)

INTERIOR SURFACE COLOR: dark gray

EXTERIOR SURFACE COLOR: dark grayishbrown

WALL THICKNESS (IN MM): rim, $5.6 \mathrm{~mm}$

INTERIOR SURFACE TREATMENT: none

EXTERIOR SURFACE TREATMENT: none

HEIGHT (IN CM): 7.0

ORIFICE DIAMETER (IN CM): 8.9

DIAMETER AT BOTTOM OF RIM OR NECK (IN CM): 7.5

BASE DIAMETER (IN CM) AND SHAPE OF BASE: 2.5; circular and concave

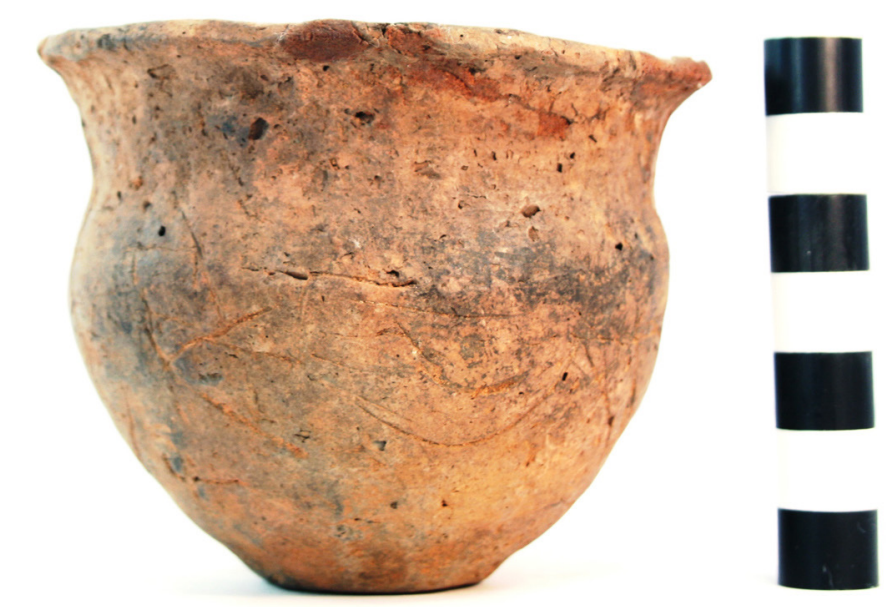

Figure 70. Plain shell-tempered jar (Vessel No. 87) in ESTIMATED VOLUME (IN LITERS): 0.37 Burial I-14 at the Goode Hunt site.

DECORATION (INCLUDING MOTIF AND ELEMENTS WHEN APPARENT): Plain (Figure 70)

PIGMENT USE AND LOCATION ON VESSEL: none

TYPE AND VARIETY (IF KNOWN): Unidentified plain ware 
SITE NAME OR SITE NUMBER: Goode Hunt

VESSEL NO.: 88, Burial I-14

VESSEL FORM: Carinated bowl

NON-PLASTICS AND PASTE: grog

RIM AND LIP FORM: Inverted rim and rounded lip

CORE COLOR: B (fired and cooled in a reducing environment)

INTERIOR SURFACE COLOR: very dark grayish-brown

EXTERIOR SURFACE COLOR: very dark grayish-brown; fire clouds on the rim

WALL THICKNESS (IN MM): rim, $5.3 \mathrm{~mm}$

INTERIOR SURFACE TREATMENT: burnished

EXTERIOR SURFACE TREATMENT: burnished

HEIGHT (IN CM): 7.6

ORIFICE DIAMETER (IN CM): 14.6

DIAMETER AT BOTTOM OF RIM OR NECK (IN CM): 14.5

BASE DIAMETER (IN CM) AND SHAPE OF BASE: 6.5 ; circular and flat

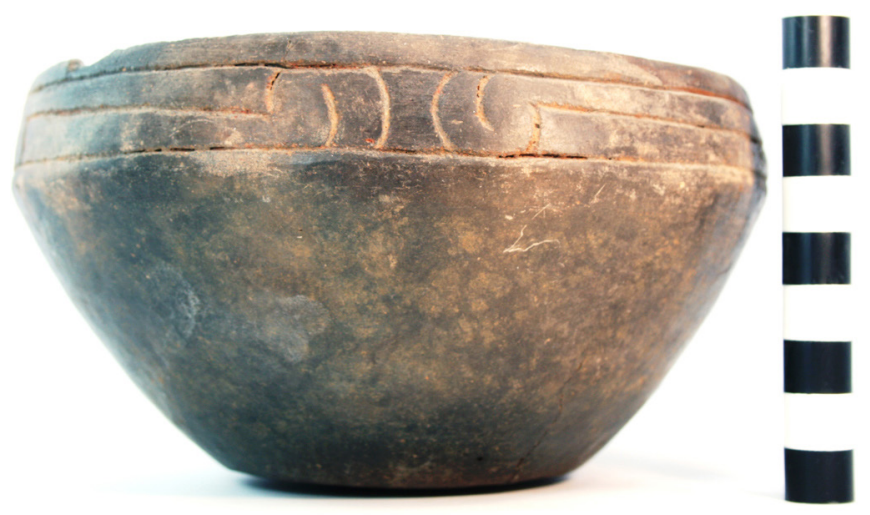

Figure 71. Simms Engraved carinated bowl (Vessel No. 88) in Burial I-14 at the Goode Hunt site.

ESTIMATED VOLUME (IN LITERS): 0.67

DECORATION (INCLUDING MOTIF AND ELEMENTS WHEN APPARENT): The rim has been divided into four panels by open vertical engraved brackets; the upper and lower parts of the panel are defined by single horizontal engraved lines (Figure 71). The panels have a single horizontal and curvilinear scroll line as well as upper and/or lower short curvilinear engraved lines between the end of the scroll and the vertical brackets.

PIGMENT USE AND LOCATION ON VESSEL: none

TYPE AND VARIETY (IF KNOWN): Simms Engraved 
SITE NAME OR SITE NUMBER: Goode Hunt

VESSEL NO.: 89, Burial I-14

VESSEL FORM: Carinated bowl

NON-PLASTICS AND PASTE: grog

RIM AND LIP FORM: Inverted rim and rounded lip

CORE COLOR: $\mathrm{F}$ (fired in a reducing environment and cooled in the open air)

INTERIOR SURFACE COLOR: red

EXTERIOR SURFACE COLOR: red

WALL THICKNESS (IN MM): $\operatorname{rim}, 5.8 \mathrm{~mm}$

INTERIOR SURFACE TREATMENT: burnished

EXTERIOR SURFACE TREATMENT: burnished

HEIGHT (IN CM): 8.3

ORIFICE DIAMETER (IN CM): 14.0

DIAMETER AT BOTTOM OF RIM OR NECK

(IN CM): 14.4

BASE DIAMETER (IN CM) AND SHAPE OF

BASE: 5.1 ; circular and concave

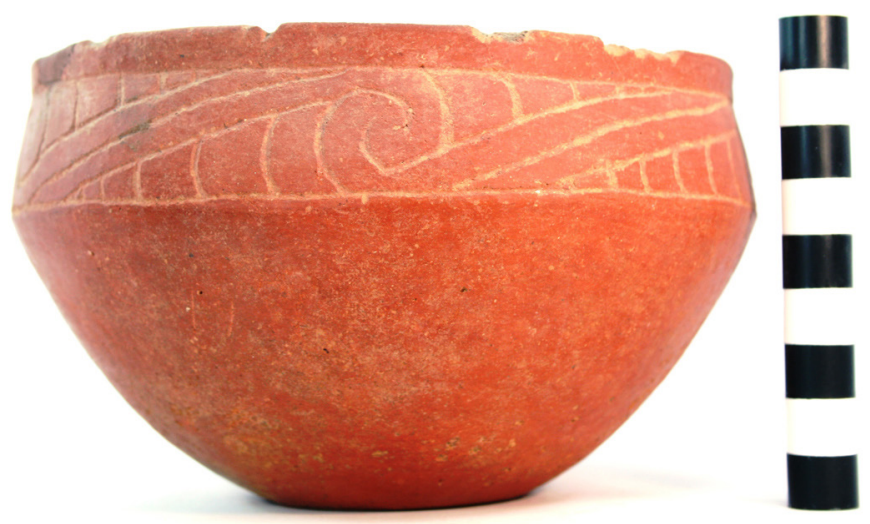

Figure 72. Taylor Engraved carinated bowl (Vessel No. 89) in Burial I-14 at the Goode Hunt site.

ESTIMATED VOLUME (IN LITERS): 0.7

DECORATION (INCLUDING MOTIF AND ELEMENTS WHEN APPARENT): The rim panel has an engraved slanting scroll motif repeated five times around the vessel (Figure 72). The scroll lines end in a hooked arm element. The upper and lower scroll fill zones are filled with curvilinear engraved lines.

PIGMENT USE AND LOCATION ON VESSEL: none

TYPE AND VARIETY (IF KNOWN): Taylor Engraved 
SITE NAME OR SITE NUMBER: Goode Hunt

VESSEL NO.: 90, Burial I-14

VESSEL FORM: Jar

NON-PLASTICS AND PASTE: grog

RIM AND LIP FORM: Everted rim and rounded lip

CORE COLOR: $\mathrm{G}$ (fired in a reducing environment and cooled in the open air)

INTERIOR SURFACE COLOR: very dark gray

EXTERIOR SURFACE COLOR: yellowishbrown; fire clouds on the rim, body, and base

WALL THICKNESS (IN MM): rim, $7.3 \mathrm{~mm}$

INTERIOR SURFACE TREATMENT: smoothed

EXTERIOR SURFACE TREATMENT: smoothed on the lower body

HEIGHT (IN CM): 23.0

ORIFICE DIAMETER (IN CM): 20.4

DIAMETER AT BOTTOM OF RIM OR NECK (IN CM): 19.2

BASE DIAMETER (IN CM) AND SHAPE OF BASE: 10.8; circular and flat

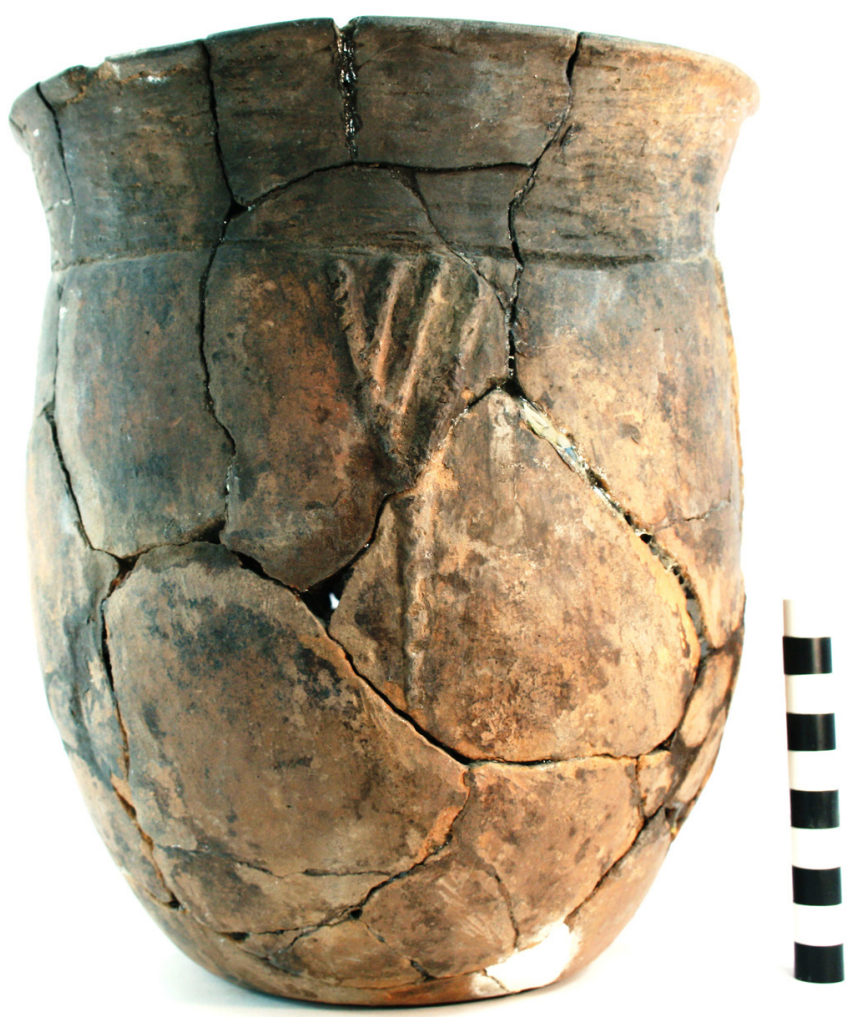

Figure 73. Appliqued jar (Vessel No. 90) in Burial I-14 at the Goode Hunt site.

ESTIMATED VOLUME (IN LITERS): 4.2

DECORATION (INCLUDING MOTIF AND ELEMENTS WHEN APPARENT): The vessel rim is plain but the vessel body has an appliqued motif repeated four times around the vessel (Figure 73). The motif consists of a near vertical appliqued fillet with three diagonal appliqued fillet branches; the fillets begin just below the rim-body juncture and extend to the mid-body.

PIGMENT USE AND LOCATION ON VESSEL: none

TYPE AND VARIETY (IF KNOWN): Unidentified utility ware 
SITE NAME OR SITE NUMBER: Goode Hunt

VESSEL NO.: 98, Burial I-15

VESSEL FORM: Carinated bowl

NON-PLASTICS AND PASTE: grog

RIM AND LIP FORM: Inverted rim and rounded lip

CORE COLOR: F (fired in a reducing environment and cooled in the open air)

INTERIOR SURFACE COLOR: dark yellowish-brown

EXTERIOR SURFACE COLOR: dark yellowish-brown; fire clouds on the rim, body, and base

WALL THICKNESS (IN MM): rim, $6.1 \mathrm{~mm}$

INTERIOR SURFACE TREATMENT: smoothed

EXTERIOR SURFACE TREATMENT: burnished

HEIGHT (IN CM): 15.2

ORIFICE DIAMETER (IN CM): 22.1

DIAMETER AT BOTTOM OF RIM OR NECK

(IN CM): 23.1

BASE DIAMETER (IN CM) AND SHAPE OF

BASE: 8.9; circular and flat

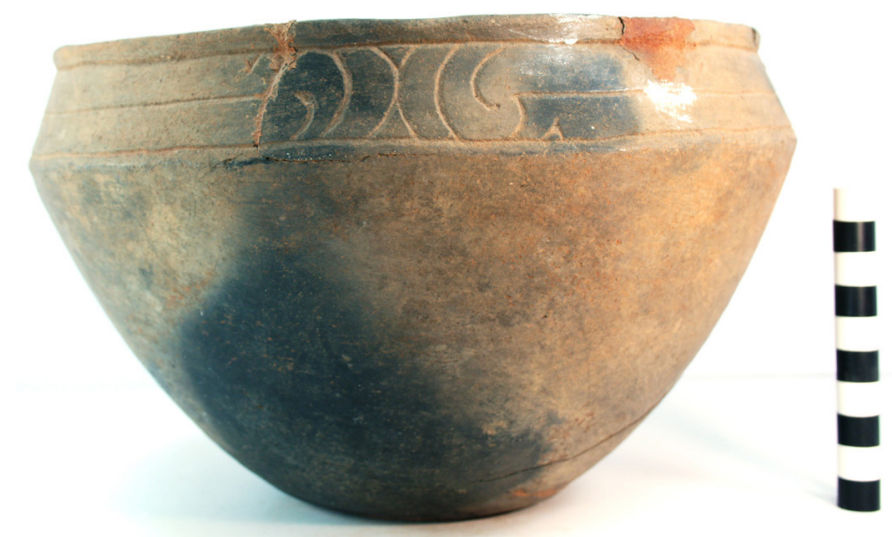

Figure 74. Simms Engraved carinated bowl (Vessel No. 98) in Burial I-15 at the Goode Hunt site.

ESTIMATED VOLUME (IN LITERS): 3.0

DECORATION (INCLUDING MOTIF AND ELEMENTS WHEN APPARENT): The vessel rim is divided into four panels by upper and lower triangular elements and connecting vertical engraved line (Figure 74). The panels each have a single horizontal and curvilinear scroll, with a singular upper curvilinear engraved line between the panel dividers and the horizontal scroll. There are also single upper and lower excised pendant triangles above and below the scroll lines (Figure 74).

PIGMENT USE AND LOCATION ON VESSEL: none

TYPE AND VARIETY (IF KNOWN): Simms Engraved 
SITE NAME OR SITE NUMBER: Goode Hunt

VESSEL NO.: 99, Burial I-15

VESSEL FORM: Jar

NON-PLASTICS AND PASTE: grog

RIM AND LIP FORM: Everted rim and rounded lip; lip notched (Figure 75)

CORE COLOR: F (fired in a reducing environment and cooled in the open air)

INTERIOR SURFACE COLOR: reddish-brown; fire clouds on the body

EXTERIOR SURFACE COLOR: yellowishbrown; fire clouds on the rim and body; organic residue on the body

WALL THICKNESS (IN MM): rim, 6.7 mm; body, $6.5 \mathrm{~mm}$

INTERIOR SURFACE TREATMENT: smoothed

EXTERIOR SURFACE TREATMENT: none

HEIGHT (IN CM): 22.7

ORIFICE DIAMETER (IN CM): N/A

DIAMETER AT BOTTOM OF RIM OR NECK (IN CM): 18.4

BASE DIAMETER (IN CM) AND SHAPE OF BASE: 7.1; circular and flat

ESTIMATED VOLUME (IN LITERS): 3.7+

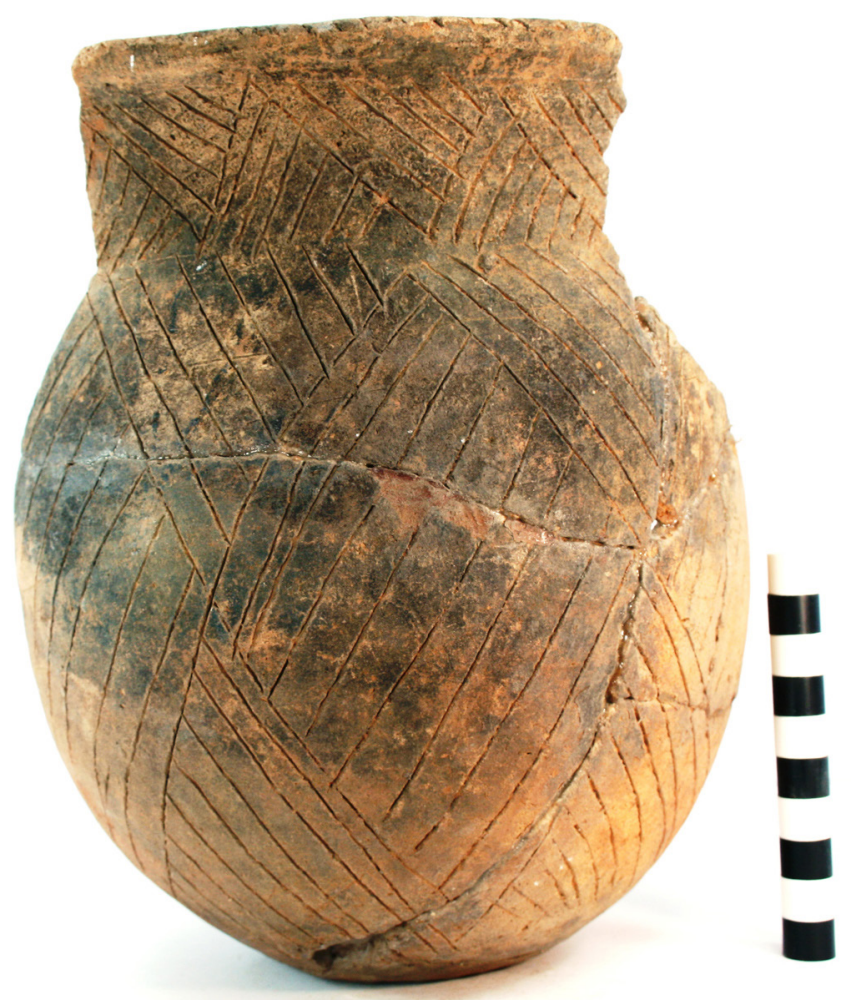

Figure 75. Pease Brushed-Incised jar (Vessel No. 99) in Burial I-15 at the Goode Hunt site.

DECORATION (INCLUDING MOTIF AND ELEMENTS WHEN APPARENT): The vessel rim has a series of upper and lower incised triangles filled with diagonal opposed lines (Figure 75). The vessel body has a central incised diamond element surrounded by smaller incised triangles filled with diagonal opposed incised lines; the central diamond element is likely repeated four times around the vessel.

PIGMENT USE AND LOCATION ON VESSEL: none

TYPE AND VARIETY (IF KNOWN): Pease Brushed-Incised 
SITE NAME OR SITE NUMBER: Goode Hunt

VESSEL NO.: 100, Burial I-15

VESSEL FORM: Bottle

NON-PLASTICS AND PASTE: grog

RIM AND LIP FORM: Missing

CORE COLOR: $\mathrm{G}$ (fired in a reducing environment and cooled in the open air)

INTERIOR SURFACE COLOR: very dark gray

EXTERIOR SURFACE COLOR: black

WALL THICKNESS (IN MM): body, $6.6 \mathrm{~mm}$

INTERIOR SURFACE TREATMENT: none

EXTERIOR SURFACE TREATMENT: burnished

HEIGHT (IN CM): 8.3+

ORIFICE DIAMETER (IN CM): N/A

DIAMETER AT BOTTOM OF RIM OR NECK

(IN CM): N/A; maximum body diameter is $8.9 \mathrm{~cm}$

BASE DIAMETER (IN CM) AND SHAPE OF

BASE: 2.5; circular and concave

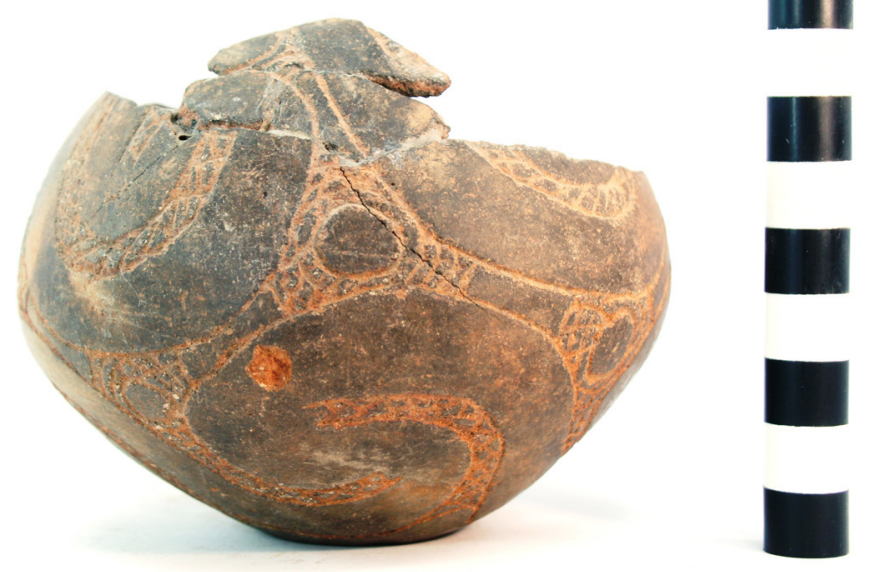

Figure 76. Hodges Engraved bottle (Vessel No. 100) in Burial I-15 at the Goode Hunt site.

ESTIMATED VOLUME (IN LITERS): 0.1+

DECORATION (INCLUDING MOTIF AND ELEMENTS WHEN APPARENT): There is a black slip on the exterior vessel surface. The vessel body has a series of meandering scrolls filled with cross-hatched zones and negative circles; the meandering scrolls end in cross-hatched hooked arm elements (Figure 76).

PIGMENT USE AND LOCATION ON VESSEL: none

TYPE AND VARIETY (IF KNOWN): Hodges Engraved 
SITE NAME OR SITE NUMBER: Goode Hunt

VESSEL NO.: 101, Burial I-15

VESSEL FORM: Globular carinated bowl

NON-PLASTICS AND PASTE: grog

RIM AND LIP FORM: Inverted rim and rounded lip

CORE COLOR: F (fired in a reducing environment and cooled in the open air)

INTERIOR SURFACE COLOR: dark reddish-brown

EXTERIOR SURFACE COLOR: dark brown; fire clouds on the rim and body

WALL THICKNESS (IN MM): rim, 4.9 mm

INTERIOR SURFACE TREATMENT: burnished

EXTERIOR SURFACE TREATMENT: burnished

HEIGHT (IN CM): 5.1

ORIFICE DIAMETER (IN CM): 9.6

DIAMETER AT BOTTOM OF RIM OR NECK

(IN CM): 10.0

BASE DIAMETER (IN CM) AND SHAPE OF

BASE: 3.1; circular and rounded

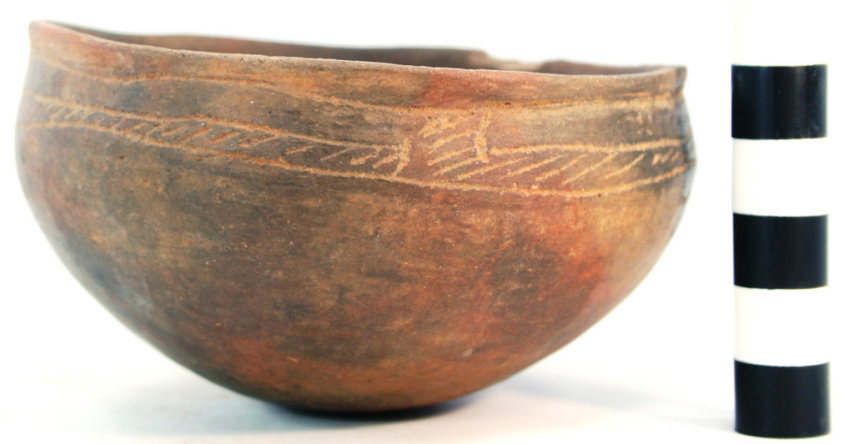

Figure 77. Engraved carinated bowl (Vessel No. 101) in Burial I-15 at the Goode Hunt site.

ESTIMATED VOLUME (IN LITERS): 0.29

DECORATION (INCLUDING MOTIF AND ELEMENTS WHEN APPARENT): The vessel rim is divided into four panels with horizontal and curvilinear scroll elements that have three upper and one lower scroll fill zone with diagonal hatched lines (Figure 77).

PIGMENT USE AND LOCATION ON VESSEL: none

TYPE AND VARIETY (IF KNOWN): Unidentified fine ware 
SITE NAME OR SITE NUMBER: Goode Hunt

VESSEL NO.: 102, Burial I-15

VESSEL FORM: Bowl

NON-PLASTICS AND PASTE: grog

RIM AND LIP FORM: Direct rim and rounded lip

CORE COLOR: $\mathrm{G}$ (fired in a reducing environment and cooled in the open air)

INTERIOR SURFACE COLOR: very dark gray

EXTERIOR SURFACE COLOR: yellowish-brown; fire clouds on the rim and body

WALL THICKNESS (IN MM): rim, $6.6 \mathrm{~mm}$

INTERIOR SURFACE TREATMENT: smoothed

EXTERIOR SURFACE TREATMENT: none

HEIGHT (IN CM): 5.7

ORIFICE DIAMETER (IN CM): 11.0

DIAMETER AT BOTTOM OF RIM OR NECK

(IN CM): N/A

BASE DIAMETER (IN CM) AND SHAPE OF

BASE: 7.1; circular and flat
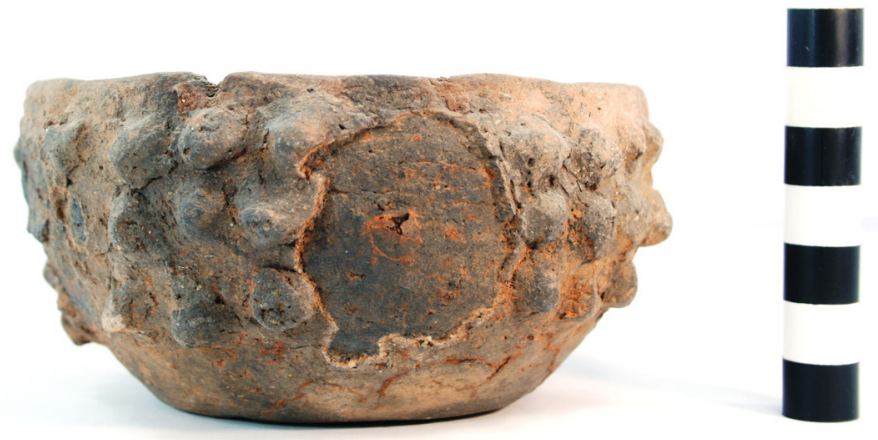

ESTIMATED VOLUME (IN LITERS): 0.25

Figure 78. Moore Noded bowl that had appliqued rattle knobs (Vessel No. 102) in Burial I-15 at the Goode Hunt site.

DECORATION (INCLUDING MOTIF AND ELEMENTS WHEN APPARENT): The vessel has three rows of small (1.0 cm diameter) appliqued nodes on either side of large appliqued rattle nodes $/ \mathrm{knobs}(3.7 \mathrm{~cm}$ diameter) that have fallen off the vessel body (Figure 78).

PIGMENT USE AND LOCATION ON VESSEL: none

TYPE AND VARIETY (IF KNOWN): Moore Noded (Webb 1959:Figure 122a-b, p) 
SITE NAME OR SITE NUMBER: Goode Hunt

VESSEL NO.: 104, Burial I-15

VESSEL FORM: Jar with opposed sets of two suspension holes (2.2 mm diameter) (Figure 79)

NON-PLASTICS AND PASTE: grog

RIM AND LIP FORM: Everted rim and rounded lip

CORE COLOR: F (fired in a reducing environment and cooled in the open air)

INTERIOR SURFACE COLOR: dark yellowish-brown; fire clouds on the rim, body, and base

EXTERIOR SURFACE COLOR: dark yellowish-

brown; fire clouds on the body and base

WALL THICKNESS (IN MM): rim, $5.6 \mathrm{~mm}$

INTERIOR SURFACE TREATMENT: smoothed

EXTERIOR SURFACE TREATMENT: smoothed on the body

HEIGHT (IN CM): 12.1

ORIFICE DIAMETER (IN CM): 12.8

DIAMETER AT BOTTOM OF RIM OR NECK

(IN CM): 11.9

BASE DIAMETER (IN CM) AND SHAPE OF

BASE: 6.4; circular and flat

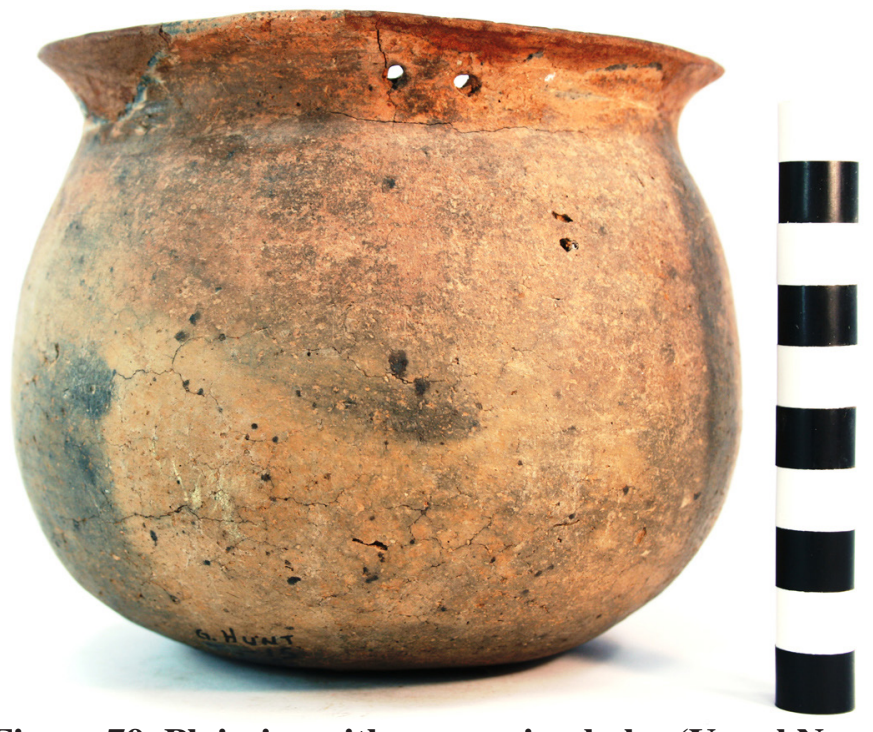

Figure 79. Plain jar with suspension holes (Vessel No. 104) in Burial I-15 at the Goode Hunt site.

ESTIMATED VOLUME (IN LITERS): 0.9

DECORATION (INCLUDING MOTIF AND ELEMENTS WHEN APPARENT): Plain (Figure 79)

PIGMENT USE AND LOCATION ON VESSEL: none

TYPE AND VARIETY (IF KNOWN): Unidentified plain ware 
SITE NAME OR SITE NUMBER: Goode Hunt

VESSEL NO.: 105, Burial I-15

VESSEL FORM: Jar

NON-PLASTICS AND PASTE: grog

RIM AND LIP FORM: Everted rim and rounded lip

CORE COLOR: F (fired in a reducing environment and cooled in the open air)

INTERIOR SURFACE COLOR: dark reddish-brown; fire clouds on the rim and body

EXTERIOR SURFACE COLOR: dark yellowishbrown; fire clouds on the rim and body

WALL THICKNESS (IN MM): rim, $4.4 \mathrm{~mm}$

INTERIOR SURFACE TREATMENT: smoothed

EXTERIOR SURFACE TREATMENT: smoothed on the body

HEIGHT (IN CM): 9.6

ORIFICE DIAMETER (IN CM): 11.5

DIAMETER AT BOTTOM OF RIM OR NECK

(IN CM): 11.2

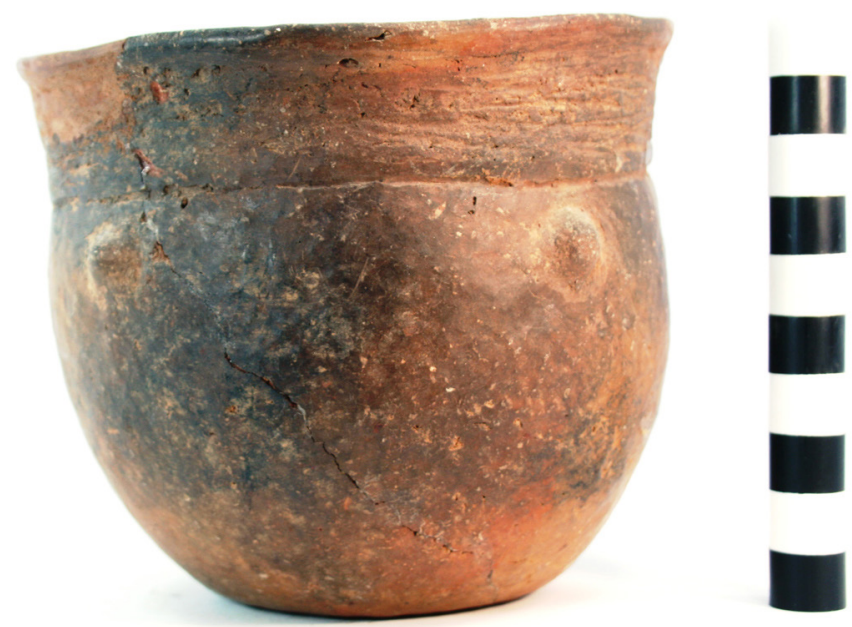

Figure 80. Brushed-appliqued jar (Vessel No. 105) in Burial I-15 at the Goode Hunt site.

BASE DIAMETER (IN CM) AND SHAPE OF BASE: 5.7; circular and flat

ESTIMATED VOLUME (IN LITERS): 0.7

DECORATION (INCLUDING MOTIF AND ELEMENTS WHEN APPARENT): The rim of the vessel has horizontal brushing marks (Figure 80$)$. The upper part of the vessel body has four appliqued nodes $(1.0 \mathrm{~cm}$ diameter) near the rim-body juncture.

PIGMENT USE AND LOCATION ON VESSEL: none

TYPE AND VARIETY (IF KNOWN): Unidentified utility ware 
SITE NAME OR SITE NUMBER: Goode Hunt

VESSEL NO.: 106, Burial I-15

VESSEL FORM: Jar

NON-PLASTICS AND PASTE: grog

RIM AND LIP FORM: Everted rim and rounded lip

CORE COLOR: $\mathrm{G}$ (fired in a reducing

environment and cooled in the open air)

INTERIOR SURFACE COLOR: very dark gray

EXTERIOR SURFACE COLOR: reddish-brown; fire clouds on the rim, body, and base; organic residue on the body

WALL THICKNESS (IN MM): rim, $6.2 \mathrm{~mm}$

INTERIOR SURFACE TREATMENT: smoothed

EXTERIOR SURFACE TREATMENT: smoothed on the body

HEIGHT (IN CM): 19.1

ORIFICE DIAMETER (IN CM): 15.8

DIAMETER AT BOTTOM OF RIM OR NECK (IN CM): 15.0

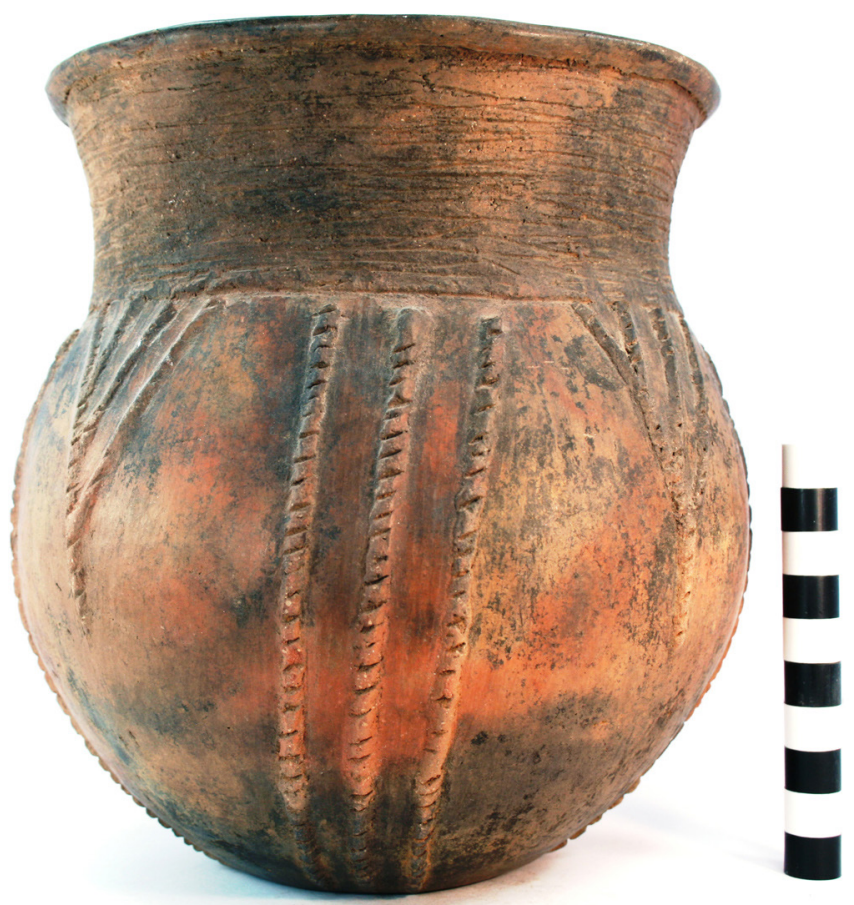

Figure 81. Brushed-appliqued jar (Vessel No. 106) in Burial I-15 at the Goode Hunt site.

BASE DIAMETER (IN CM) AND SHAPE OF BASE: 7.6; circular and flat

ESTIMATED VOLUME (IN LITERS): 2.8

DECORATION (INCLUDING MOTIF AND ELEMENTS WHEN APPARENT): The rim has horizontal brushed-incised marks and lines (Figure 81). The vessel body is divided into four panels by sets of three vertical appliqued fillets that extend from the rim-body juncture to the vessel base. In the panels are single branching appliqued fillets, with four branches, that extend midway down the vessel body (Figure 81).

PIGMENT USE AND LOCATION ON VESSEL: none

TYPE AND VARIETY (IF KNOWN): Unidentified utility ware 
SITE NAME OR SITE NUMBER: Goode Hunt

VESSEL NO.: 108, Burial I-16

VESSEL FORM: Carinated bowl

NON-PLASTICS AND PASTE: grog and bone

RIM AND LIP FORM: Direct rim and rounded lip

CORE COLOR: F (fired in a reducing environment and cooled in the open air)

INTERIOR SURFACE COLOR: dark yellowish-brown; fire clouds on the rim; organic residue on the rim

EXTERIOR SURFACE COLOR: yellowish-brown; fire clouds on the rim and body; organic residue on the rim and body

WALL THICKNESS (IN MM): rim, $6.1 \mathrm{~mm}$

INTERIOR SURFACE TREATMENT: smoothed

EXTERIOR SURFACE TREATMENT: burnished

HEIGHT (IN CM): 14.0

ORIFICE DIAMETER (IN CM): 22.2

DIAMETER AT BOTTOM OF RIM OR NECK

(IN CM): 22.2

BASE DIAMETER (IN CM) AND SHAPE OF

BASE: 8.2 ; circular and flat

ESTIMATED VOLUME (IN LITERS): 2.8

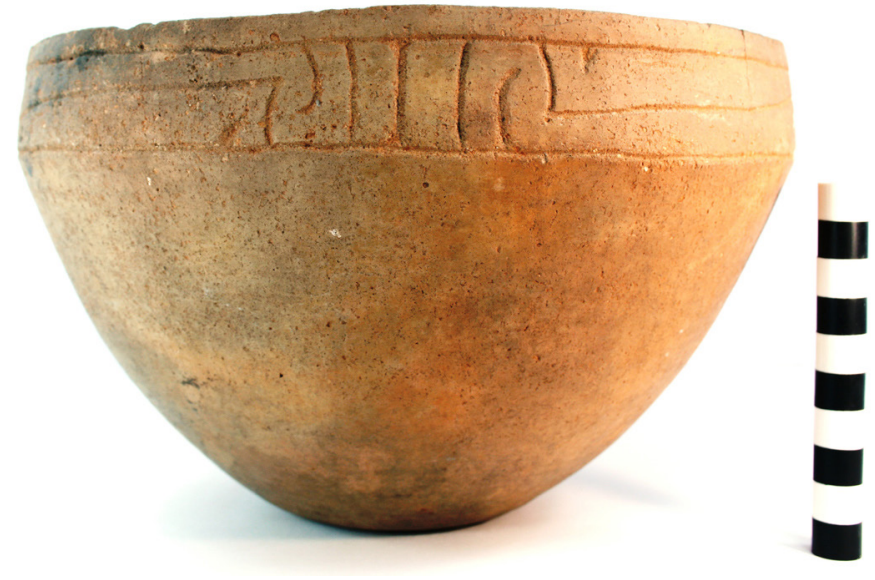

Figure 82. Simms Engraved carinated bowl (Vessel No. 108) in Burial I-16 at the Clements site.

DECORATION (INCLUDING MOTIF AND ELEMENTS WHEN APPARENT): The rim is divided into four horizontal panels by sets of three vertical engraved lines (Figure 82) and upper and lower horizontal engraved lines. Within the panels are single diagonal and curvilinear engraved scroll lines. On either side of the scrolls are single upper and lower curvilinear line elements, and there are single upper and lower excised pendant triangles (Figure 82).

PIGMENT USE AND LOCATION ON VESSEL: none

TYPE AND VARIETY (IF KNOWN): Simms Engraved 
SITE NAME OR SITE NUMBER: Goode Hunt

VESSEL NO.: 109, Burial I-16

VESSEL FORM: Bottle

NON-PLASTICS AND PASTE: grog

RIM AND LIP FORM: Everted rim and rounded lip

CORE COLOR: B (fired and cooled in a reducing environment)

INTERIOR SURFACE COLOR: very dark grayish-brown

EXTERIOR SURFACE COLOR: very dark grayish-brown

WALL THICKNESS (IN MM): rim, $5.1 \mathrm{~mm}$

INTERIOR SURFACE TREATMENT: none

EXTERIOR SURFACE TREATMENT: burnished

HEIGHT (IN CM): 8.9

ORIFICE DIAMETER (IN CM): 3.1

DIAMETER AT BOTTOM OF RIM OR NECK (IN CM): 3.7 ; maximum body diameter is $7.8 \mathrm{~cm}$

BASE DIAMETER (IN CM) AND SHAPE OF

BASE: 5.7; circular and flat

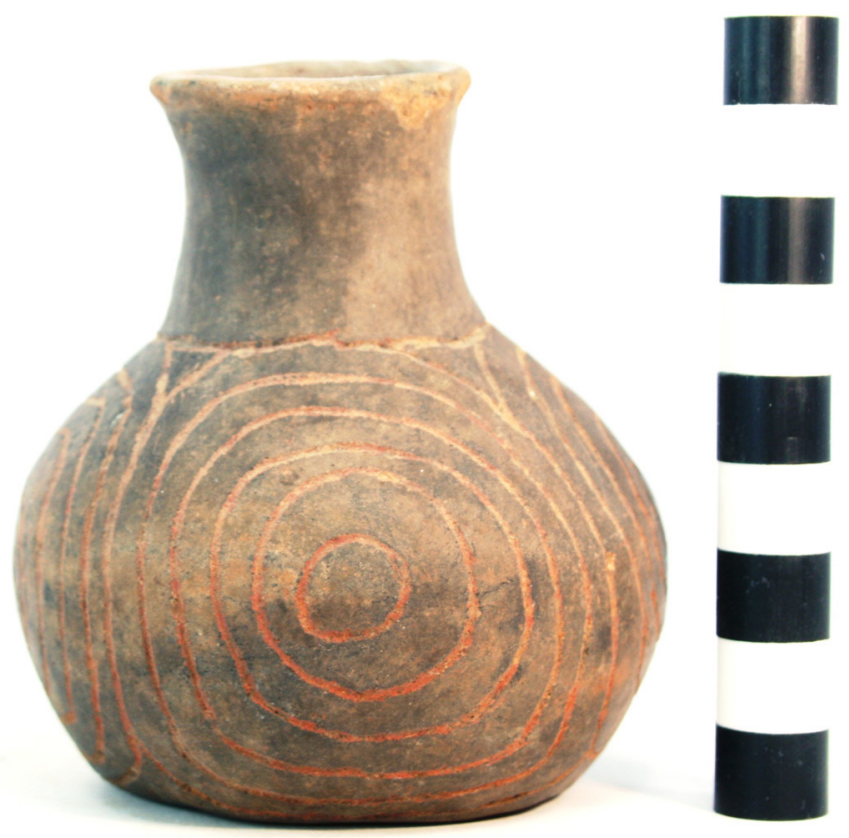

Figure 83. cf. Hatchel Engraved bottle (Vessel No. 109) in Burial I-16 at the Goode Hunt site.

ESTIMATED VOLUME (IN LITERS): 0.2

DECORATION (INCLUDING MOTIF AND ELEMENTS WHEN APPARENT): The vessel body has been divided into four panels by upper and lower triangle elements and a connecting vertical engraved line. Within each of the panel are a series of four concentric engraved circles (Figure 83).

PIGMENT USE AND LOCATION ON VESSEL: red pigment in the engraved lines

TYPE AND VARIETY (IF KNOWN): cf. Hatchel Engraved 
SITE NAME OR SITE NUMBER: Goode Hunt

VESSEL NO.: 110, Burial I-16

VESSEL FORM: Compound bowl

NON-PLASTICS AND PASTE: grog

RIM AND LIP FORM: Everted rim and rounded lip

CORE COLOR: F (fired in a reducing environment and cooled in the open air)

INTERIOR SURFACE COLOR: dark reddish-brown; fire clouds on the rim, body, and base

EXTERIOR SURFACE COLOR: dark reddish-brown; fire clouds on the rim, body, and base

WALL THICKNESS (IN MM): rim, $4.6 \mathrm{~mm}$

INTERIOR SURFACE TREATMENT: burnished

EXTERIOR SURFACE TREATMENT: burnished

HEIGHT (IN CM): 5.1

ORIFICE DIAMETER (IN CM): 8.9

DIAMETER AT BOTTOM OF RIM OR NECK (IN CM): 8.3

BASE DIAMETER (IN CM) AND SHAPE OF BASE: 5.1; circular and rounded

ESTIMATED VOLUME (IN LITERS): 0.36

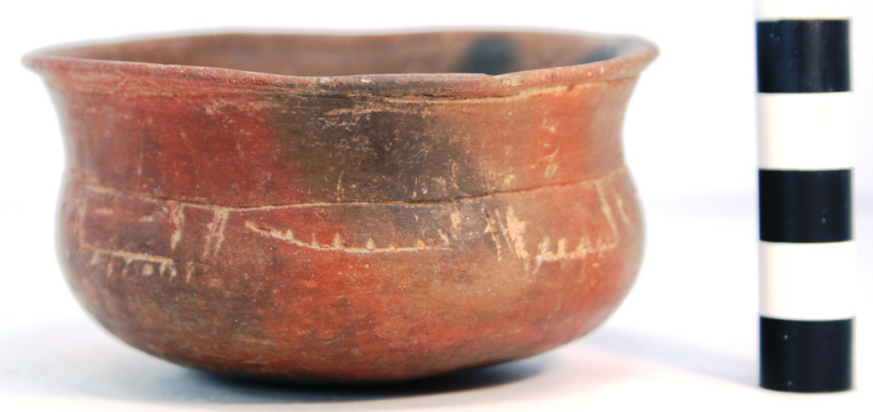

Figure 84. Simms Engraved, var. Darco compound bowl (Vessel No. 110) in Burial I-16 at the Goode Hunt site.

DECORATION (INCLUDING MOTIF AND ELEMENTS WHEN APPARENT): The upper panel of the vessel is defined by upper and lower horizontal engraved lines. The lower rim panel has a series of either two vertical-diagonal engraved lines with downward-pointing tick marks or five curvilinear to rectilinear engraved elements with either upper or downward-pointing tick marks (Figure 84).

PIGMENT USE AND LOCATION ON VESSEL: none

TYPE AND VARIETY (IF KNOWN): Simms Engraved, var. Darco 
SITE NAME OR SITE NUMBER: Goode Hunt

VESSEL NO.: 111, Burial I-16

VESSEL FORM: Carinated bowl

NON-PLASTICS AND PASTE: grog

RIM AND LIP FORM: Inverted rim and rounded lip

CORE COLOR: $\mathrm{G}$ (fired in a reducing environment and cooled in the open air)

INTERIOR SURFACE COLOR: dark gray

EXTERIOR SURFACE COLOR: dark reddish-brown

WALL THICKNESS (IN MM): rim, $3.9 \mathrm{~mm}$

INTERIOR SURFACE TREATMENT: burnished

EXTERIOR SURFACE TREATMENT: burnished

HEIGHT (IN CM): 6.2

ORIFICE DIAMETER (IN CM): 10.2

DIAMETER AT BOTTOM OF RIM OR NECK (IN CM): 12.0

BASE DIAMETER (IN CM) AND SHAPE OF BASE: 3.7; circular and rounded

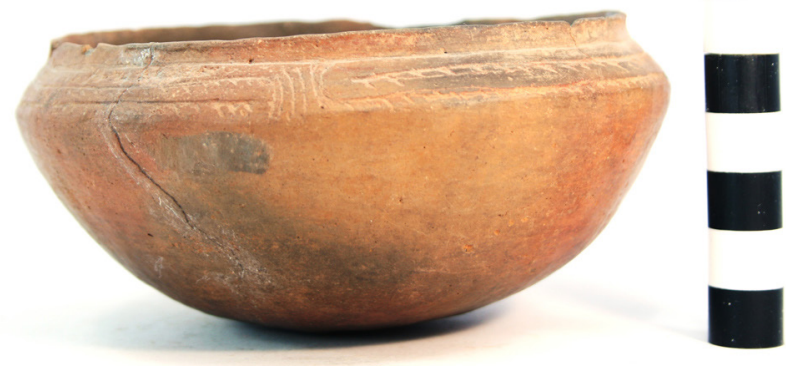

Figure 85. Simms Engraved carinated bowl (Vessel No. 111) in Burial I-16 at the Goode Hunt site.

ESTIMATED VOLUME (IN LITERS): 0.38

DECORATION (INCLUDING MOTIF AND ELEMENTS WHEN APPARENT): The rim is divided into three panels by vertical brackets filled with curvilinear engraved lines (Figure 85). The panels have a single centrally-placed horizontal engraved line with downward-pointing tick marks. The bottom horizontal engraved line on the panels also has downward-pointing tick marks that end at the vessel carination (Figure $85)$.

PIGMENT USE AND LOCATION ON VESSEL: none

TYPE AND VARIETY (IF KNOWN): Simms Engraved 
SITE NAME OR SITE NUMBER: Goode Hunt

VESSEL NO.: 112, Burial I-16

VESSEL FORM: Deep bowl

NON-PLASTICS AND PASTE: shell

RIM AND LIP FORM: Everted rim and rounded lip

CORE COLOR: $\mathrm{G}$ (fired in a reducing environment and cooled in the open air)

INTERIOR SURFACE COLOR: dark gray

EXTERIOR SURFACE COLOR: dark yellowish-brown; fire clouds on the rim, body, and base

WALL THICKNESS (IN MM): rim, $5.1 \mathrm{~mm}$

INTERIOR SURFACE TREATMENT: smoothed

EXTERIOR SURFACE TREATMENT:

burnished

HEIGHT (IN CM): 14.6

ORIFICE DIAMETER (IN CM): 20.3

DIAMETER AT BOTTOM OF RIM OR NECK

(IN CM): N/A

BASE DIAMETER (IN CM) AND SHAPE OF

BASE: 9.5; circular and flat

ESTIMATED VOLUME (IN LITERS): 2.4

Figure 86. Hudson Engraved deep bowl (Vessel No.

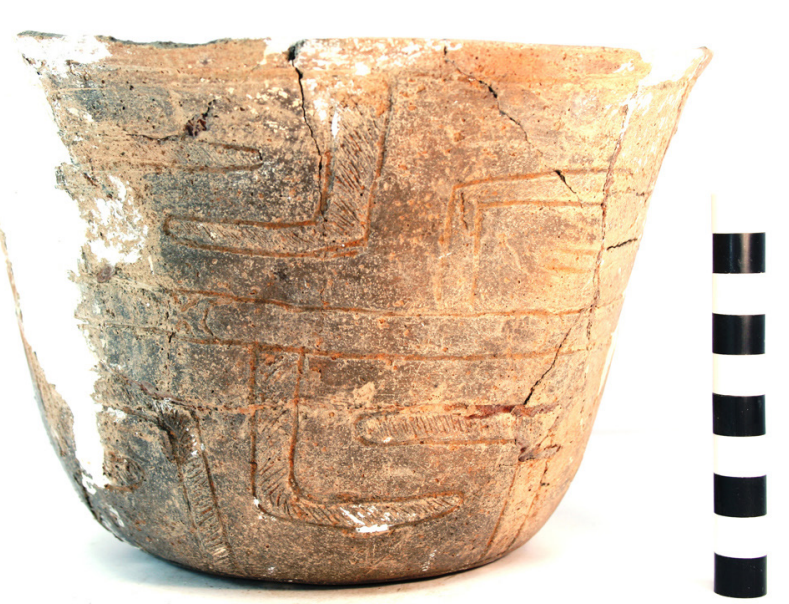

112) in Burial I-16 at the Goode Hunt site.

DECORATION (INCLUDING MOTIF AND ELEMENTS WHEN APPARENT): The vessel has two stacked horizontal engraved panels divided by two horizontal engraved lines that encircle the vessel (Figure 86). Within the two stacked panels are five sets of nested upper and lower L-shaped engraved elements filled with hatched incised lines.

PIGMENT USE AND LOCATION ON VESSEL: none

TYPE AND VARIETY (IF KNOWN): Hudson Engraved 
SITE NAME OR SITE NUMBER: Goode Hunt

VESSEL NO.: 113, Burial I-16

VESSEL FORM: Jar

NON-PLASTICS AND PASTE: grog

RIM AND LIP FORM: Everted rim and rounded lip

CORE COLOR: F (fired in a reducing environment and cooled in the open air)

INTERIOR SURFACE COLOR: reddish-brown; fire clouds on the rim and base

EXTERIOR SURFACE COLOR: reddish-brown; fire clouds on the rim and body

WALL THICKNESS (IN MM): rim, $6.6 \mathrm{~mm}$; body, $8.7 \mathrm{~mm}$

INTERIOR SURFACE TREATMENT: smoothed

EXTERIOR SURFACE TREATMENT: none

HEIGHT (IN CM): 18.5

ORIFICE DIAMETER (IN CM): 16.5

DIAMETER AT BOTTOM OF RIM OR NECK (IN CM): 15.3

BASE DIAMETER (IN CM) AND SHAPE OF

BASE: 7.6; circular and flat ESTIMATED VOLUME (IN LITERS): 2.7

Figure 87. cf. Pease Brushed-Incised jar (Vessel No.

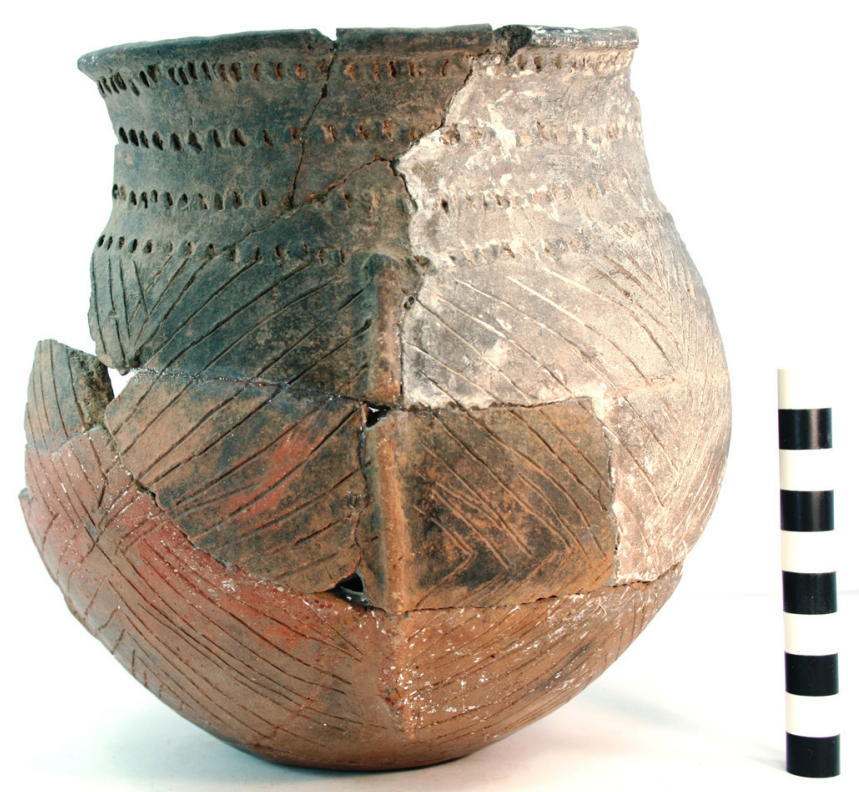
113 ) in Burial I-16 at the Goode Hunt site.

DECORATION (INCLUDING MOTIF AND ELEMENTS WHEN APPARENT): The rim of the vessel has four horizontal rows of tool punctations (Figure 87). The vessel body is divided into vertical panels by vertical appliqued ridges. The panels are filled with sets of opposed incised triangles filled with diagonal opposed incised lines (Figure 87).

PIGMENT USE AND LOCATION ON VESSEL: none

TYPE AND VARIETY (IF KNOWN): cf. Pease Brushed-Incised 
SITE NAME OR SITE NUMBER: Goode Hunt

VESSEL NO.: 121, Burial I-17

VESSEL FORM: Bottle

NON-PLASTICS AND PASTE: grog

RIM AND LIP FORM: Everted rim and rounded lip

CORE COLOR: $\mathrm{G}$ (fired in a reducing environment and cooled in the open air)

INTERIOR SURFACE COLOR: dark grayish-brown

EXTERIOR SURFACE COLOR: dark yellowishbrown; fire clouds on the rim and body

WALL THICKNESS (IN MM): rim, $4.5 \mathrm{~mm}$

INTERIOR SURFACE TREATMENT: none

EXTERIOR SURFACE TREATMENT: burnished

HEIGHT (IN CM): 11.5

ORIFICE DIAMETER (IN CM): 4.3

DIAMETER AT BOTTOM OF RIM OR NECK

(IN CM): 3.6; maximum body diameter is $9.3 \mathrm{~cm}$.

BASE DIAMETER (IN CM) AND SHAPE OF

BASE: 3.8; circular and rounded

ESTIMATED VOLUME (IN LITERS): 0.18

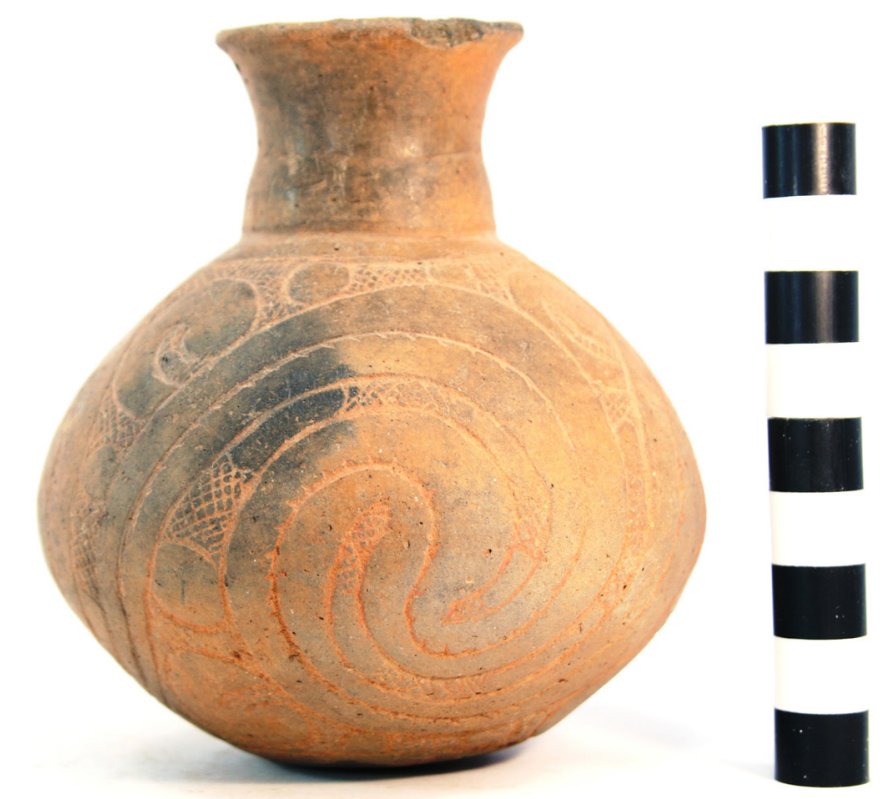

Figure 88. Hodges Engraved bottle (Vessel No. 121) in Burial I-17 at the Goode Hunt site.

DECORATION (INCLUDING MOTIF AND ELEMENTS WHEN APPARENT): The vessel body has a continuous meandering engraved scroll with downward-pointing tick marks. To either side of the meandering scroll are three sets of upper and lower horizontal and triangular-shaped scroll fill zones that have cross-hatched areas, negative ovals and small circles, and large circles with a bisecting cross-hatched spur within them (Figure 88).

PIGMENT USE AND LOCATION ON VESSEL: none

TYPE AND VARIETY (IF KNOWN): Hodges Engraved 
SITE NAME OR SITE NUMBER: Goode Hunt

VESSEL NO.: 122, Burial I-17

VESSEL FORM: Carinated bowl

NON-PLASTICS AND PASTE: grog

RIM AND LIP FORM: Inverted rim and rounded lip

CORE COLOR: $\mathrm{G}$ (fired in a reducing environment and cooled in the open air)

INTERIOR SURFACE COLOR: dark grayish-brown

EXTERIOR SURFACE COLOR: dark yellowish-

brown; fire clouds on the rim, body, and base

WALL THICKNESS (IN MM): rim, 5.7 mm

INTERIOR SURFACE TREATMENT: smoothed

EXTERIOR SURFACE TREATMENT: burnished

HEIGHT (IN CM): 4.4

ORIFICE DIAMETER (IN CM): 8.9

DIAMETER AT BOTTOM OF RIM OR NECK

(IN CM): 9.3

BASE DIAMETER (IN CM) AND SHAPE OF

BASE: 3.7; circular and flat

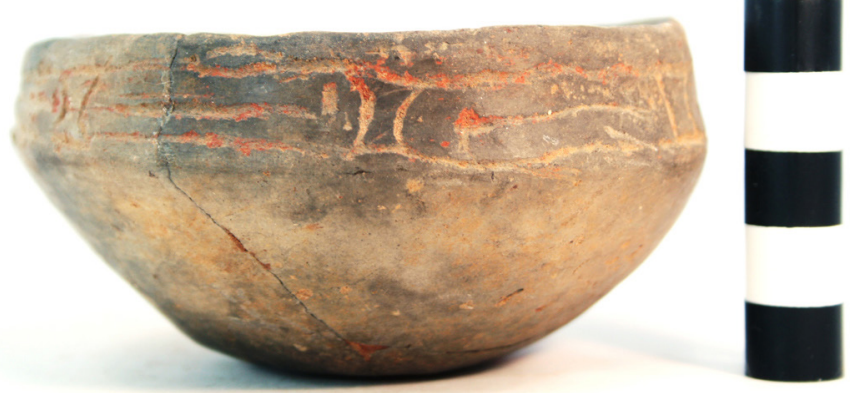

Figure 89. Simms Engraved carinated bowl (Vessel No. 122) in Burial I-17 at the Goode Hunt site.

ESTIMATED VOLUME (IN LITERS): 0.24

DECORATION (INCLUDING MOTIF AND ELEMENTS WHEN APPARENT): The vessel rim is divided into five panels by sets of open vertical brackets; the upper and lower parts of the panels have single horizontal engraved lines (Figure 89). In the panels are single horizontal and curvilinear to vertical scroll lines.

PIGMENT USE AND LOCATION ON VESSEL: red pigment in the engraved lines

TYPE AND VARIETY (IF KNOWN): Simms Engraved 
SITE NAME OR SITE NUMBER: Goode Hunt

VESSEL NO.: 123, Burial I-17

VESSEL FORM: Jar

NON-PLASTICS AND PASTE: grog

RIM AND LIP FORM: Everted rim and rounded lip

CORE COLOR: F (fired in a reducing environment and cooled in the open air)

INTERIOR SURFACE COLOR: reddish-brown; fire clouds on the rim

EXTERIOR SURFACE COLOR: reddish-brown; fire clouds on the rim, body, and base

WALL THICKNESS (IN MM): rim, $5.4 \mathrm{~mm}$

INTERIOR SURFACE TREATMENT: smoothed

EXTERIOR SURFACE TREATMENT: none

HEIGHT (IN CM): 8.9

ORIFICE DIAMETER (IN CM): 11.7

DIAMETER AT BOTTOM OF RIM OR NECK

(IN CM): 9.8

BASE DIAMETER (IN CM) AND SHAPE OF

BASE: 5.1; circular and flat

ESTIMATED VOLUME (IN LITERS): 0.63

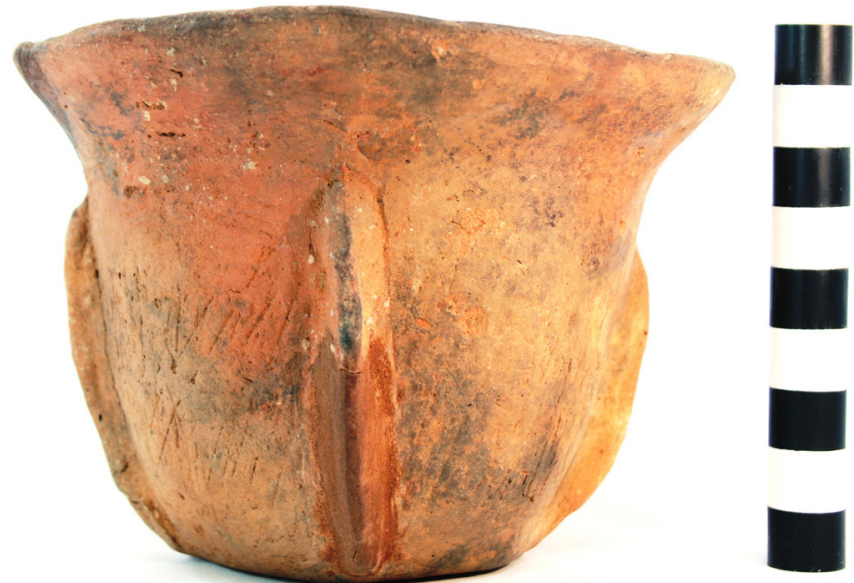

Figure 90. Brushed-incised and appliqued jar (Vessel No. 123) in Burial I-17 at the Goode Hunt site.

DECORATION (INCLUDING MOTIF AND ELEMENTS WHEN APPARENT): The rim of the vessel is plain. The vessel body is divided into four panels by four vertical appliqued ridges (Figure 90). The panels have either diagonal or overlapping brushed-incised marks and lines.

PIGMENT USE AND LOCATION ON VESSEL: none

TYPE AND VARIETY (IF KNOWN): Unidentified utility ware 
The different kinds of vessels placed in the graves as funerary offerings, along with the orientation and placement of the 17 burials at the Goode Hunt site, suggest that there at least two spatially and temporally distinct burial groupings in the cemetery. The first two burial groupings likely date to some part of the Late Caddo period, after ca. A.D. 1500, but these interments predate the early historic use of the site.

The earliest burials at the Goode Hunt site are Burials I-1, I-8, I-12, and I-13, and these burials are in graves where the head of the deceased face to the north (see Figure 3); Burial I-1 is placed generally in the central part of the overall cemetery, suggesting it is the founding grave. Ceramic vessels placed as funerary offerings in this group of burials include a Hatchel Engraved bottle $(n=1)$, engraved carinated bowls of uncertain ceramic type $(n=2)$, a Karnack Brushed-Incised jar $(n=1)$, an incised jar of unknown type $(n=1)$, and plain jars $(n=2)$. Hatchel Engraved vessels tend to be common in ca. A.D. 1400-1550 Texarkana phase contexts at sites along the Red River (Perttula 2014a:89).

The second group of burials at the Goode Hunt site includes Burials I-6 and I-10 at the northern and southern ends of the site (see Figure 3). These burials are in graves where the head of the deceased faced to the southwest, much like the burials in the third and last burial grouping (see below). Only a few ceramic vessels were placed in the graves as funerary offerings, among them a Bailey Engraved bottle, a Hodges Engraved deep bowl, an engraved bowl of uncertain type, and a plain jar. The occurrence of the one Hodges Engraved deep bowl indicates that at least Burial I-6 postdates ca. A.D. 1550-1600 (Perttula 2014a:89); the other Hodges Engraved vessels in the burials at the Goode Hunt site are bottles.

The remaining 11 burials in the Goode Hunt cemetery (Burials I-2, I-3, I-4, I-5, I-7, I-9, I-11, I-14, I-15, I-16, and I-17) are thought to be part of the third and last burial grouping (see Figure 3). These burials are oriented in northeast to southwest rows, with the head of the deceased facing to the southwest. One of the burials in this group, Burial I-7, has a piece of historic brass or cupreous material that had been placed on the grave floor. Most of these burials also have ceramic vessels of types and varieties that are known to generally occur only in post-A.D. 1680 contexts (see Schambach and Miller 1984; Perttula et al. 2010), including Foster Trailed Incised, var. Moore, Keno Trailed, var. Phillips, Simms Engraved, var. Darco, and cf. Cabaness Engraved. The ceramic vessels present as funerary offerings in this third and last burial grouping include Hodges Engraved bottles and carinated bowls ( $n=7)$, an engraved bottle of uncertain type $(n=1)$, Simms Engraved carinated bowls $(n=16)$, Simms Engraved, var. Darco carinated bowls $(n=3)$, Taylor Engraved carinated bowls $(n=2)$, cf. Cabaness Engraved $(n=1)$, a shell-tempered Hudson Engraved deep bowl ( $\mathrm{n}=1)$, Keno Trailed bowls and bottles $(\mathrm{n}=3$, including Keno Trailed, var. Phillips), an engraved carinated bowl of uncertain type $(\mathrm{n}=1)$, Foster Trailed-Incised, var. Moore jars $(n=2)$, cf. Pease Brushed-Incised jars ( $n=3)$, cf. Karnack Brushed-Incised jars ( $n=1)$, Mockingbird Punctated jars $(n=2)$, Maydelle Incised jars $(n=2)$, Moore Noded bowls $(n=1)$, brushed jars $(n=1)$, brushedappliqued jars $(\mathrm{n}=2)$, a brushed-incised-appliqued jar $(\mathrm{n}=1)$, an incised jar $(\mathrm{n}=1)$, incised-punctated jars $(n=1)$, appliqued jars $(n=1)$, and plain jars $(n=3)$, including one that was shell-tempered. The dominance of Simms Engraved, Simms Engraved, var. Darco, and Hodges Engraved vessels in the third burial grouping at the Goode Hunt site suggests that these interments are contemporaneous with sites such as Cedar Grove (3LA97, Schambach and Miller 1984; Kelley 2012), Eli Moores (41BW2) (Perttula 2014b), and several village areas and mound platform features at the Hatchel site (41BW3) (Perttula 2014c), all on the Red River in the Great Bend area. 


\section{Clements Site (41CS25)}

The Clements site is a late 17th to early 18th century (ca. 1680-1720) Nasoni Caddo site in Cass County, Texas, in the northeastern part of the state, a few miles west of Atlanta, Texas. It is situated on a knoll near the headwaters of Black Bayou (Figure 91), a stream that flows in a southeasterly direction for approximately 30 kilometers to its confluence with the Red River near the Belcher mound site (16CD12, see Webb 1959). The site is also not far from the headwaters of other streams flowing north into the Sulphur River, another major tributary to the Red River, and only a few miles west of the Caddo Trace (see Foster 1998:232) leading to an important portage across the Sulphur River. The Caddo Trace was an aboriginal trail that led from the Hasinai Caddo settlements in East Texas to the Kadohadacho settlements on the Red River in the general area of Texarkana, Texas. From Henri Joutel's 1687 description of the trace from the Hasinai villages along the Neches River to the upper Nasoni village on the Red River west

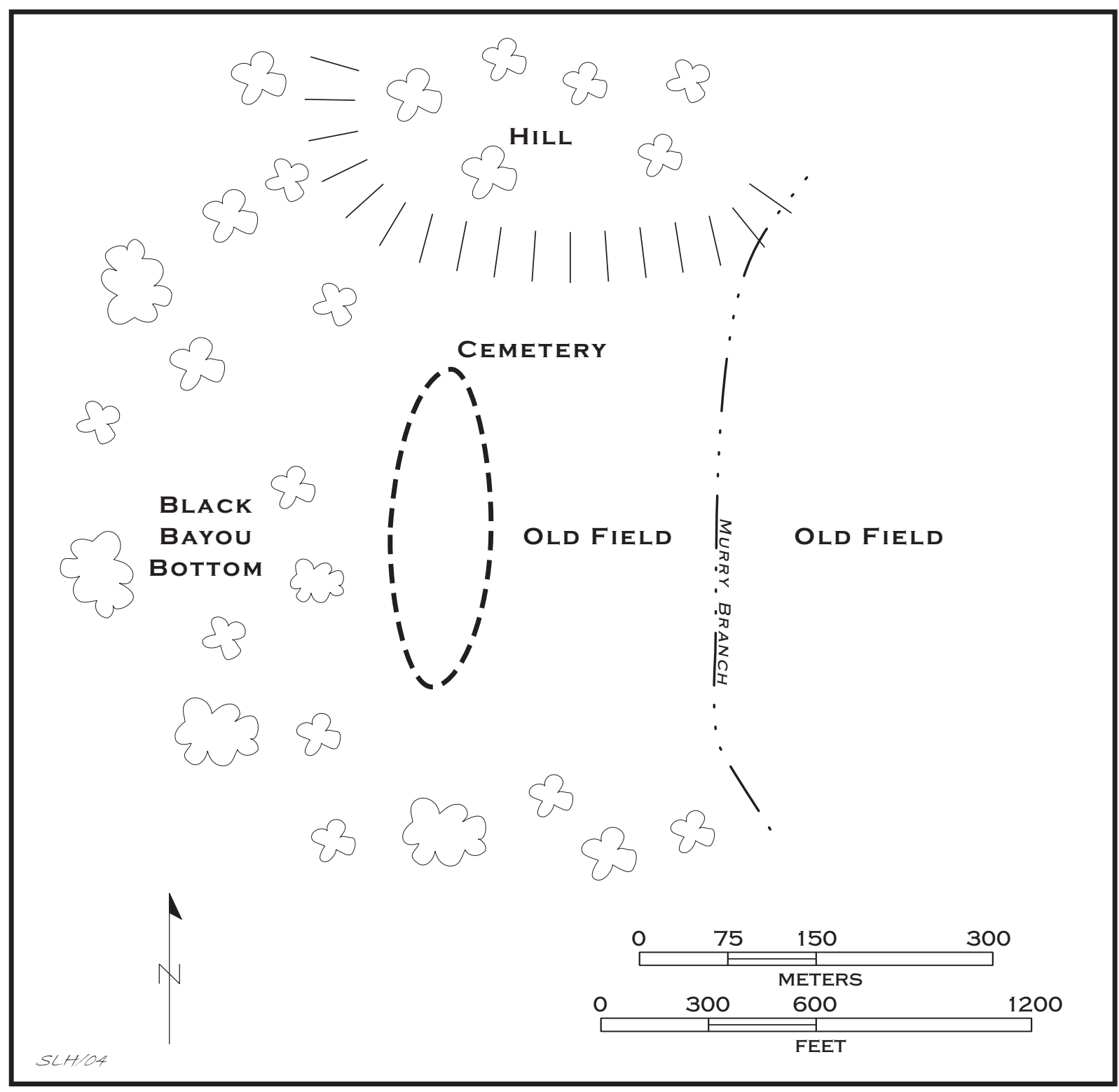

Figure 91. Map of the Clements site area (after Jackson 1932a). 
of Texarkana, it appears that the Clements site was situated near the Caddo Trace. According to Foster's (1998:320) reconstruction of Joutel's route, on June 20, 1687, the group of Frenchmen with Joutel, and their Caddo guides, camped for the night "six to eight miles west of Atlanta." This is the approximate location of the Goode Hunt site (41CS23), the other Nasoni Caddo site discussed in this monograph. Kenmotsu et al. (1993:115) have suggested that the "area of the Hunt (41CS23), Clements (41CS25), and Atlanta State Park (41CS37) sites, located west of Atlanta, Texas, and situated some 50 miles southwest of Spirit Lake, Arkansas, represents a possible location of Nisione [Nisohone or Nasoni] in 1542."

\section{Excavations and Burial Features}

There are a few letters written by Will T. Scott in 1900 concerning his work at the Clements site (see Gonzalez et al. 2005:Appendix 1), as well as 1941 correspondence between A. T. Jackson and Samuel D. Dickinson - archaeologists in Texas and Arkansas, respectively - about the site and its collections. Other primary documents available concerning the history of archaeological investigations at the Clements site include Jackson's unpublished 1932 report on the University of Texas work there (Jackson 1932a), and an article by Dickinson (1941) entitled "Certain Vessels from the Clements Place, an Historic Caddo Site" published in the Bulletin of the Texas Archeological and Paleontological Society.

Scott indicated in a March 20, 1900 letter to the American Museum of Natural History (AMNH) that he discovered the site in about 1898 on his farm in Cass County, Texas. He mentioned that the site was 0.5 miles from a small creek, a tributary to Black Bayou, and was on a low knoll, just outside Atlanta, Texas. He identified and uncovered 17 burials, about 3-6 feet in depth, that contained pottery vessels, stone arrow points, large points, ground stone tools (i.e., tomahawks), and shell necklaces. To interest the AMNH in the purchase of his collection, he suggested the burials and artifacts were left by the Aztec. In a June 20, 1900 letter, however, he asserted that they were in fact Caddo burials, since the "Cadow [sic] Indians at one time inhabited the vicinity."

In the course of his digging at the site, Scott uncovered ceramic vessels, ceramic pipes, large chipped stone knives, polished celts, marine shell ornaments, mussel shells (including a mussel shell hoe), and clay pigments. His digging techniques were rudimentary, because when A. T. Jackson (1932a) returned to the Clements site in 1932, many of the previously dug graves still contained an abundance of artifacts (many now broken) that had apparently been overlooked by Scott in his hasty excavations.

The burials were in rows, according to Scott, with the heads to the north and the feet of the deceased to the south; in Jackson's (1932a) later investigations at the site, however, he discovered that almost all the burials were oriented with the head to the east and the feet to the west, though there were a few notable exceptions (see below). Scott also wrote that almost all of the skeletal material in the majority of the graves had disappeared, marked by a "chalky line... where the bones had decayed " (March 20, 1900 letter). The grave goods he found had the large ceramic vessels (jars?) and bowls placed near the feet, with the smaller vessels, including bottles, around the head. The "smallest bottles [were] just under the side of the head at the base of the skull." In the only comments on the association of specific funerary objects in particular burials, Scott wrote to Frederic Ward Putnam of the AMNH that he found blue glass beads in the same grave as two small "phial-shaped" bottles; some of the larger vessels also came from the same grave. The large chipped stone knives were "all in one grave."

In March 1900, W. T. Scott wrote to the AMNH to see if they were interested in purchasing his collection, or what was left of his collection from the site. We know from Dickinson's account that Scott "obtained a large collection of artifacts [from the Clements site], which he sold and gave to various people" (Dickinson 1941:117). Sometime prior to 1900, Scott had left his farm in Cass County and moved to 
the town of Gypsum in Hardeman County, Texas, near the Texas Panhandle. In his April 19, 1900 letter, he indicated that he needed the money, and asked for the sum of $\$ 200$ for the collection from the AMNH.

Before the AMNH agreed to purchase the collection from Will Scott, they asked for a catalog of the collections, along with pencil sketches of the pottery vessels and other artifacts (April 9, 1900 letter from F. W. Putnam to Will T. Scott). Scott provided a rudimentary list, along with a series of well-done vessel drawings (Perttula et al. 2010:Figure 3-10) he had prepared by a Mr. Webber in July 1899, along with six photographs taken by Bonner's in Quanah, Texas (Perttula et al. 2010:Figure 11).

The AMNH agreed to Scott's price on May 4, 1900, provided that Scott pack and ship his collection to the museum. Scott apparently shipped the collection on May 17, 1900.

The W. T. Scott collection at the AMNH includes 34 ceramic vessels -15 bottles, one Clements Brushed olla, 10 carinated bowls, two compound bowls, two bowls, and four jars, two complete ceramic elbow pipes, and a third elbow pipe bowl. There is also a small piece of green clay pigment, three large chipped stone knives, three ground stone celts, one mussel shell hoe, five unmodified mussel shell valves and three unmodified mussel shell umbos. The most intriguing artifacts in the Scott collection from the site are 15 marine shell zoomorphic pendants. Webb (1959:170) has pointed out that the pendants resemble "a slender, tailed animal, with head, neck, long body, and blunt tail," and may be lizard effigies. Jackson (1932a) suggested they may be representations of locusts or grasshoppers, and Kay (1984:197) opined that they may be insects, perhaps a spider. Regardless of their possible representational meaning, their general rarity in Caddo burials suggests that they were powerful symbols worn by the social elite that had access to exotic marine shell raw materials or goods. Jackson (1932a) had recovered four marine shell zoomorphic pendants from a small midden deposit adjacent to Burials 14 and 15 at the Clements site.

There were also in the collections two large and four small shell ear disks of the Clements style (Perttula and Green 2006) made from marine conch shell. These would have been worn singly on each ear, being attached to the ear through a single small central perforation $(2-3 \mathrm{~mm}$ in diameter) on the disk. Two of the burials excavated by Jackson (1932a) at the Clements site had shell ear disks, and there are identical ear disks at the Cedar Grove site (Kay 1984:Figure 13-20a-b), Hardman (Early 1993:Figure 83a-b), and two protohistoric Caddo sites in the White Oak Creek basin in East Texas (Perttula and Green 2006).

A single ear pendant is in the collection. It is made from a conch columella, and is bi-pointed, with small perforations $(0.2 \mathrm{~mm})$ at both ends for attachment. There are six barrel-shaped conch shell beads in the W. T. Scott collection. They are rectangular to cylindrical in shape, with cut and ground ends, and smoothed to polished bodies.

There is a single strand of 25 blue glass beads in the W. T. Scott collection from the Clements site. During A.T. Jackson's (1932a) investigations at the site, five of the 22 Caddo burials had glass beads as funerary objects, with a total of 45 beads being recovered in the investigations. The beads are simple drawn beads with a Robin's Egg Blue color. In the Kidd and Kidd (1970) bead classification system, they are identified as Type IIa40. This simply means that the beads are drawn beads of a Robin's Egg Blue color made with a single layer of glass, then rounded through re-heating. The beads are also opaque (i.e., light does not penetrate the bead). The 25 beads are medium (4-6 mm in length, $n=20)$ and large (6-10 $\mathrm{mm}$ in length, $\mathrm{n}=5$ ) in size.

Glass beads, in general, are rare on Caddo sites before the first quarter of the $18^{\text {th }}$ century, though, and when found on earlier sites, generally include only a few large blue beads (see Cole 1975:Table 19; Perttula 1992:190-191). There are exceptions, however, as the Nabedache Caddo village visited by the 
late 1680s La Salle Expedition on San Pedro Creek had many thousands of large blue beads found at two sites in Houston County, Texas (41HO64/65, see Perttula 2005:87-94). In a bead seriation (Perttula et al. 2010:Table 5), the Clements bead assemblage fall readily at the beginning of the sequence, dating earlier than the Deshazo (Creel 1982) and Womack (Harris et al. 1965) site beads; those two sites were occupied by different Caddo groups between ca. 1700-1730, and a pre-1700 age may be a reasonable approximation of either when Caddo groups were living in the vicinity of the Clements site, or the period of principal trading activities between the Caddo and French traders.

Not included in this collection were seven ceramic vessels, a shell pendant, and a shell bead that Will Scott gave to his sister, Mrs. C. A. Smith (Dickinson 1941:117). The vessels eventually made their way to Samuel D. Dickinson. These vessels ("of the finest pieces of pottery" in the Scott collection) included two Hodges Engraved bottles (Dickinson 1941:Plate 19, nos. 1 and 2), two Cass Appliqued jars (Dickinson 1941:Plate 20, Nos. 1 and 2), two diminutive engraved bottles (Dickinson 1941:Plate 21, Nos. 2 and 3 ) that are much like two bottles now in the AMNH collection (see Perttula et al. 2010:Figure 2), and a unique bi-lobed Hodges Engraved bottle (Dickinson 1941:Plate 21, No. 1). The vessel shape of the latter is reminiscent of a four-lobed Keno Trailed bottle vessel illustrated by Moore (1909:Figure 81) from the Glendora site in northern Louisiana, and another four-lobed Belcher Engraved bottle from the Foster site (Moore 1912:Plate XLIV) along the Red River.

The Clements site was next excavated by the University of Texas in 1932 (Jackson 1932a; Lewis 1987). At that time, 22 Caddo burials were exposed over a $600 \mathrm{~m}^{2}$ area adjacent to a small midden deposit near Burials 14 and 15 (Figure 92). Twenty of the burials were apparently single, primary extended inhumations, but a possible semi-flexed (or greatly disturbed) burial (Burial 2) was also recorded, along with a multiple interment (Burial 11) containing three individuals. According to Jackson (1932a), the three individuals are from three superimposed primary extended burials rather than the product of one burial event, a very rare if not unique mortuary context for prehistoric or early historic Caddo burials.

There were apparently several different burial groupings at the Clements site. This is based more than anything on the size and orientation of the burial pits across the cemetery (Table 3, see also Figure 92), but the kinds of funerary objects placed with the individuals may help to differentiate the age and sex of the deceased along with their status as well as the status of their lineages. Jackson (1932a) believed that Burial 11C was the earliest of the Clements site interments because this individual was laid out so its head faced to the north. This was unlike all the other burials here but very similar to Burial I-1 at the Goode Hunt site (Jackson 1932b) that was placed at the center of the cemetery there. Funerary objects in that burial were consistent with it being among the earliest burial groups at Goode Hunt. This does not appear to be the case at Clements, however, and the best candidate for the earliest Caddo burial at the site-perhaps representing a senior member of the founding lineage-is Burial 8, that of an adult female in the central part of the cemetery (see Figure 92).

The majority of the burials (79 percent) at the Clements site were placed in an extended supine (i.e., flat on their back) position in the graves, with their heads at the eastern end of the burial pit, facing west to southwest. The burial pits of three individuals were oriented southeast (100-170 degrees), while two others had burial pits that were oriented southwest (235-250 degrees). About 76 percent of the burials at the Goode Hunt site were also in an extended supine position with their heads facing to the southwest or west.

As best we can tell from the distribution of the different kinds of funerary objects in the 22 burials, the Clements site was used as a place for the Caddo to bury their dead during at least two different periods or episodes that may have lasted a generation or more. The earlier cemetery use includes burials in several north-south rows at the western end of the site, including burials 8-13,16-20, and 21 (see Figure 


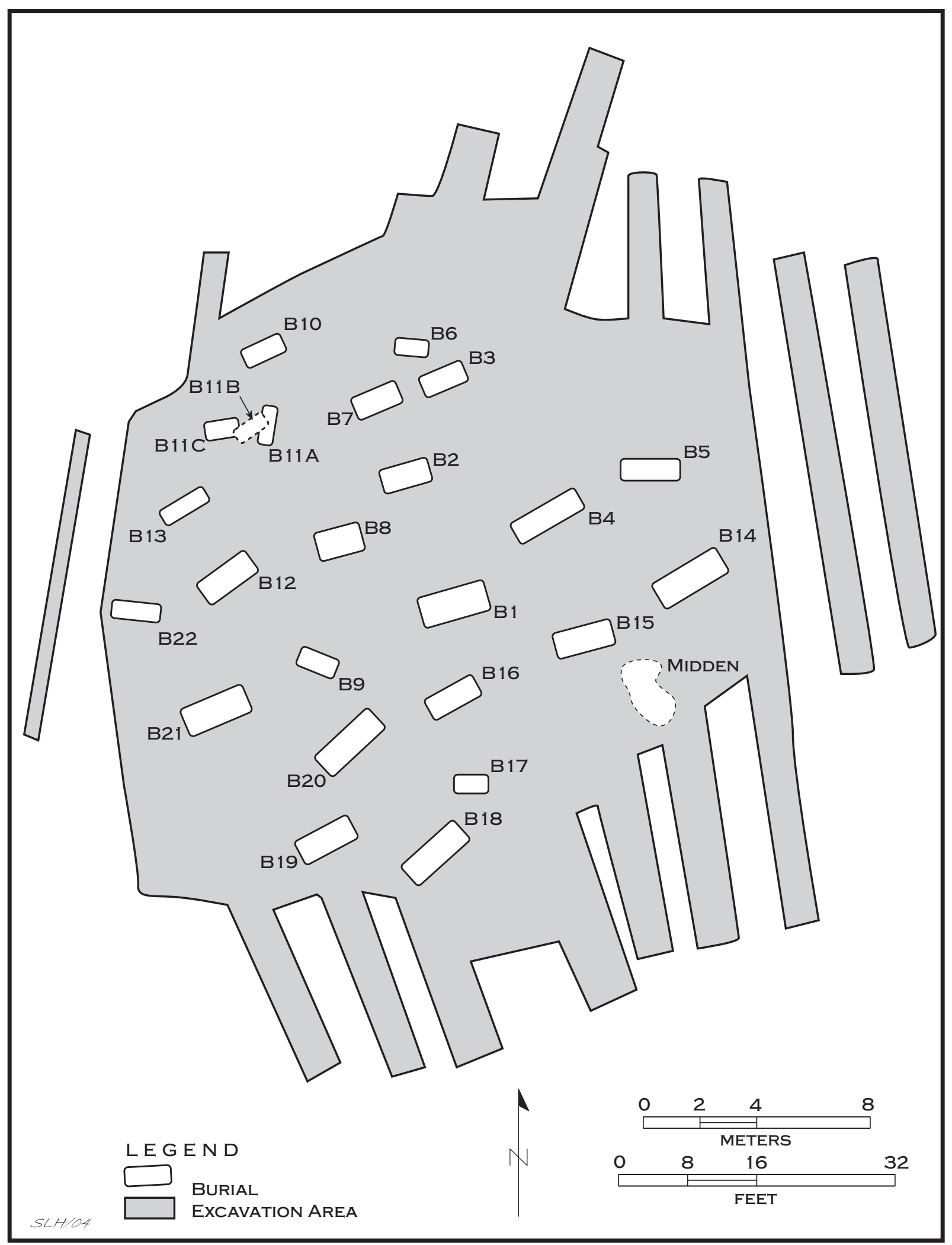

Figure 92. Map of the arrangement of the Clements site burials. 
Table 3. Information on the size, depth, and orientation of the Clements site burials.

\begin{tabular}{|c|c|c|c|c|c|}
\hline Burial \# & $\begin{array}{l}\text { Length } \\
\text { (ft.) }\end{array}$ & $\begin{array}{l}\text { Width } \\
\text { (ft.) }\end{array}$ & $\begin{array}{l}\text { Depth } \\
\text { (ft.) }\end{array}$ & $\begin{array}{l}\text { Orientation } \\
\text { (degrees) }\end{array}$ & $\begin{array}{l}\text { Head Position } \\
\text { in the grave; } \\
\text { age and sex }\end{array}$ \\
\hline No. 1 & 8.5 & 3.0 & 2.1 & 50 & west; adult, IND \\
\hline No. 2 & 6.1 & 3.0 & 1.5 & 250 & $\begin{array}{l}\text { east; adolescent, } \\
\text { female }\end{array}$ \\
\hline No. 3 & 6.2 & 2.1 & 1.8 & 235 & IND; child, IND \\
\hline No. 4 & 8.7 & 3.4 & 2.3 & 50 & east, adult, IND \\
\hline No. 5 & 6.8 & 2.8 & 1.9 & 80 & east; IND \\
\hline No. 6 & 4.5 & 1.9 & 1.1 & 85 & west; IND \\
\hline No. 7 & 5.9 & 3.1 & 2.0 & 60 & east; IND \\
\hline No. 8 & 6.5 & 3.3 & 2.5 & 105 & $\begin{array}{l}\text { east; adult, female } \\
\text { and adolescent, male }\end{array}$ \\
\hline No. 9 & 4.7 & 2.7 & 2.4 & 100 & east; adult, IND \\
\hline No. 10 & 4.8 & 2.3 & 1.6 & 55 & east; IND \\
\hline No. 11 & 9.7 & 5.4 & $\begin{array}{l}1.3 \\
2.4 \\
3.0\end{array}$ & $\begin{array}{c}75 \\
80 \\
170\end{array}$ & $\begin{array}{l}\text { A, south; adult, IND } \\
\text { B, east, adult, IND } \\
\text { C, east, adult, IND }\end{array}$ \\
\hline No. 12 & 7.3 & 3.1 & 1.4 & $\mathrm{NE}$ & east; adult, IND \\
\hline No. 13 & 5.7 & 1.8 & 0.9 & 55 & west, adult, IND \\
\hline No. 14 & 9.0 & 3.5 & 2.9 & 50 & east; adult, IND \\
\hline No. 15 & 6.0 & 2.8 & 2.4 & 65 & IND; adult, IND \\
\hline No. 16 & 6.8 & 2.8 & 1.8 & 60 & IND; adult, IND \\
\hline No. 17 & 4.5 & 2.0 & 1.5 & 85 & east; adult, IND \\
\hline No. 18 & 8.1 & 3.0 & 1.0 & 35 & IND; adult, female \\
\hline No. 19 & 7.7 & 2.9 & 1.3 & 55 & IND; IND \\
\hline No. 20 & 6.0 & 2.8 & 1.5 & $\mathrm{NE}$ & IND; IND \\
\hline No. 21 & 7.8 & 3.3 & 1.8 & 45 & west; IND \\
\hline No. 22 & 5.2 & 1.8 & 1.5 & 80 & IND; IND \\
\hline
\end{tabular}

$\mathrm{IND}=$ indeterminate

92). Sometime around the beginning of the 18th century, the eastern half of the cemetery was used (Burials 1-7, 14, and 15); these burials had among their various offerings a few strands of glass beads traded to the Nasoni Caddo by Europeans. One of the western burials (Burial 21) also was part of this later cemetery, as this individual had a Keno Trailed, var. Phillips bowl among its funerary offerings, and this form is an excellent ceramic marker for the period between ca. 1700-1730 (cf. Schambach and Miller 1984; Perino 1981, 1983).

In addition to the burials that Jackson (1932a) exposed and documented at the Clements site, he also encountered what he considered to be an unusual midden [or trash] deposit near two of the burials (Burials 14 and 15) in the southern part of the cemetery (see Figure 92). According to Jackson (1932a):

Scattered throughout the midden deposit, and in association with animal bones, were found a few human bones, such as those of the fingers, and fragments of arm and leg bones and small pieces of skull. Some of the long bones were broken but not split. The presence of all of these 
bones could scarcely be attributed to the activities of rodents, and seem to have found their way into the midden deposit through the agency of man. Whether this fact signifies ceremonial cannibalism is problematical.

In Jackson's summary of the findings, he concluded that "it is doubtful as to whether this [the presence of human remains in the midden deposits] indicates ceremonial cannibalism." Rather than relying on a cannibalism argument to account for the human remains in a midden deposit adjacent to Burials 14 and 15 , it makes much more sense to take into account the extensive previous digging at the Clements site by W. T. Scott and others more than 30 years before the University of Texas began their work at the site. The crude earlier digging that Jackson (1932a) described, with a very considerable scattering and broadcasting of human remains and artifacts, is a much more likely scenario to account for broken and unbroken pieces of human skeletal material ending up in midden dirt and backdirt near a few of the burials. Lewis (1987:Table 3) noted that the midden area had human remains from two adults of indeterminate age and sex; it would not surprise us to discover that these remains represent scattered pieces from the adults buried in Burial 14 and 15 (see Figure 92).

Jackson (1932a) had after all noted that the site had been disturbed prior to the University of Texas excavations. Much of the skeletal remains had been moved and rearranged, and many artifacts had been removed from the graves, or broken and tossed back in the burial pit. Of the 52 vessels found by Jackson (1932a), for instance, only 19.2 percent were complete. As we know now, this disturbance to the Clements site burials was the result of extensive digging by W. T. Scott and others, who dug at least 17 burials here, but did not remove any of the skeletal remains.

Jackson (1932a) had indicated that the site had been discovered about 1900, when we know from Scott's letters that it must have been a few years before that, since his collection from the Clements site was sold to the AMNH in 1900. Jackson was unaware that any of Scott's collection had been sold to the AMNH, although he had been told that "about a dozen vessels from this site were sent to the Smithsonian Institution at that time [1900]." Since there are no materials from the Clements site at the Smithsonian Institution, we suspect that this inaccurate information actually was referring to the materials sold by Scott to the AMNH. Jackson was aware of Scott's considerable digging at the site, and he also knew about a small collection of ceramic vessels from the Clements site that were in the hands of Samuel D. Dickinson of Prescott, Arkansas (Jackson 1932a). Dickinson, a well-known archaeologist at the time in Arkansas (cf. Dickinson 1936; Dickinson and Lemley 1939; see also Lemley 1936), received these vessels from the daughter of Will Scott's sister, a Mrs. J. B. Hesterly of Prescott, Arkansas (Dickinson 1941:118).

Nevertheless, a relatively diverse assemblage of funerary objects was recovered from the site during Jackson's work at the Clements site (Table 4). Conch shell ornaments made from Gulf Coast marine shells were the most common item placed with the deceased, including probable bead necklaces from at least three burials (Burials 2, 8, and 15), bracelets (Burial 15), ear discs, and portions of pendant necklaces. The zoomorphic style of the conch shell pendants from the associated midden at the Clements site is very similar to ones recovered at both the Belcher (Webb 1959:172-173) and Cedar Grove (Kay 1984:Figure 13-22) sites, as well as from Belcher phase components at the Foster, Friday, and Battle sites along the Red River in southwestern Arkansas.

Half of the Clements burials had conch shell ornaments, which certainly seems indicative of a ready access to these materials of exotic origin (i.e., the conch shell would have been found along the Gulf Coast of Texas); a similar relationship was noted in the Chakanina phase burials at the Cedar Grove site (3LA97) on the Red River in southwestern Arkansas (Trubowitz 1984; Perttula 1992:Table 16). Along with the shell ornaments were European glass beads (1-26 beads per burial) from five separate interments 
Table 4. Funerary objects at the Clements site, Cass County, Texas recovered in 1932 University of Texas excavations.

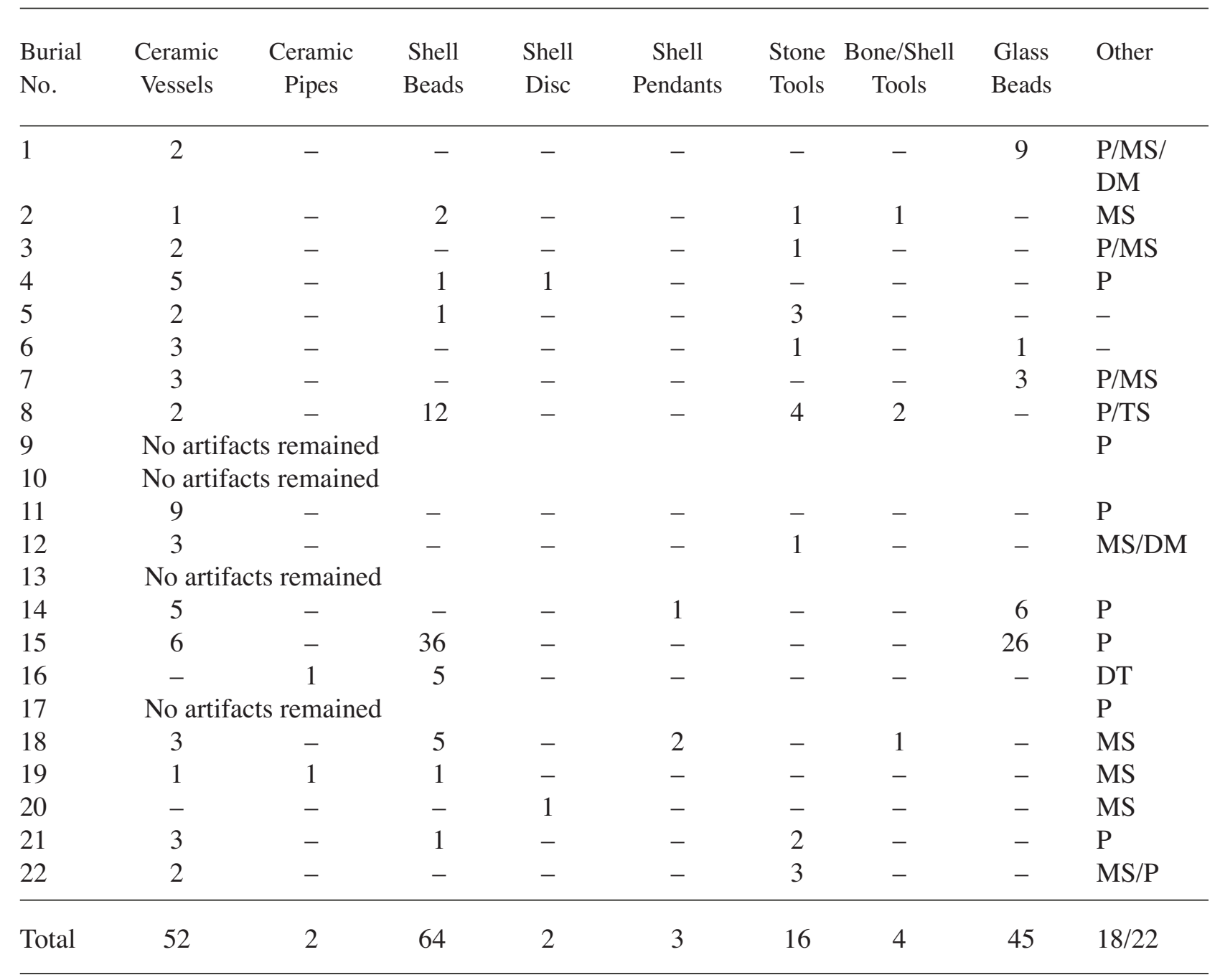

$\mathrm{P}=$ pigment; $\mathrm{MS}=$ mussel shell; $\mathrm{TS}=$ turtle shell; $\mathrm{DM}=$ deer mandible; $\mathrm{DT}=\mathrm{dog}$ tooth

at Clements. In two instances, shell beads or other shell ornaments were found together in the same burial with the European glass beads (see Table 4).

Pottery vessels were also commonly placed as funerary objects in the burials, with as many as nine vessels placed with Burial 11. Others had between 1-6 vessels per burial (see Table 4). Fifteen of the burials at the Clements site had clay pigment (green, brown, red, and gray colors) and/or mussel shell offerings. Four of the five burials with European trade goods had pigments, particularly a green pigment from a local glauconitic clay. 


\section{Ceramic Vessels from Burial Features}

SITE NAME OR SITE NUMBER: Clements (41CS25)

VESSEL NO.: 2, Burial H-1

VESSEL FORM: Jar

NON-PLASTICS AND PASTE: grog

RIM AND LIP FORM: Everted rim and rounded lip

CORE COLOR: $\mathrm{G}$ (fired in a reducing environment and cooled in the open air)

INTERIOR SURFACE COLOR: dark grayish-brown

EXTERIOR SURFACE COLOR: dark

yellowish-brown; fire clouds on the rim, body, and the base

WALL THICKNESS (IN MM): rim, $8.4 \mathrm{~mm}$

INTERIOR SURFACE TREATMENT: smoothed

EXTERIOR SURFACE TREATMENT: smoothed on the body

HEIGHT (IN CM): 31.1

ORIFICE DIAMETER (IN CM): 24.8

DIAMETER AT BOTTOM OF RIM OR NECK

(IN CM): 21.2

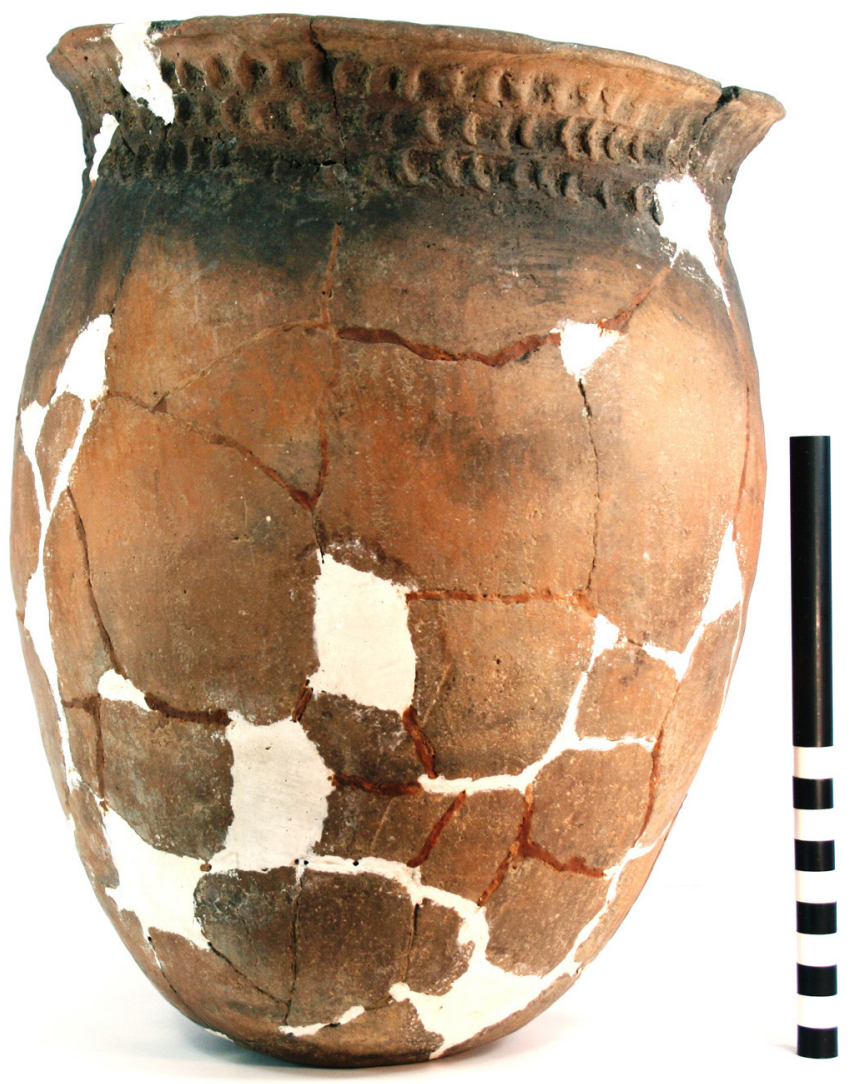

Figure 93. Mockingbird Punctated jar (Vessel No. 2) from Burial H-1 at the Clements site.

BASE DIAMETER (IN CM) AND SHAPE OF BASE: 8.9;

circular and flat

ESTIMATED VOLUME (IN LITERS): 11.3

DECORATION (INCLUDING MOTIF AND ELEMENTS WHEN APPARENT): The rim of the vessel is decorated with horizontal rows of tool punctations (Figure 93).

PIGMENT USE AND LOCATION ON VESSEL: none

TYPE AND VARIETY (IF KNOWN): Mockingbird Punctated 
SITE NAME OR SITE NUMBER: Clements

VESSEL NO.: 10, Burial H-2

VESSEL FORM: Jar

NON-PLASTICS AND PASTE: bone

RIM AND LIP FORM: Everted rim and rounded lip

CORE COLOR: F (fired in a reducing environment and cooled in the open air, see Teltser 1993:Figure 2)

INTERIOR SURFACE COLOR: reddish-brown to yellowish-brown; fire clouds on the rim; organic residue on the rim

EXTERIOR SURFACE COLOR: yellowishbrown; fire clouds on the rim, body, and base

WALL THICKNESS (IN MM): rim, $8.9 \mathrm{~mm}$

INTERIOR SURFACE TREATMENT: smoothed

EXTERIOR SURFACE TREATMENT: none

HEIGHT (IN CM): 28.2

ORIFICE DIAMETER (IN CM): 26.7

DIAMETER AT BOTTOM OF RIM OR NECK (IN CM): 26.1

BASE DIAMETER (IN CM) AND SHAPE OF

BASE: 7.2; circular and concave

ESTIMATED VOLUME (IN LITERS): 9.8

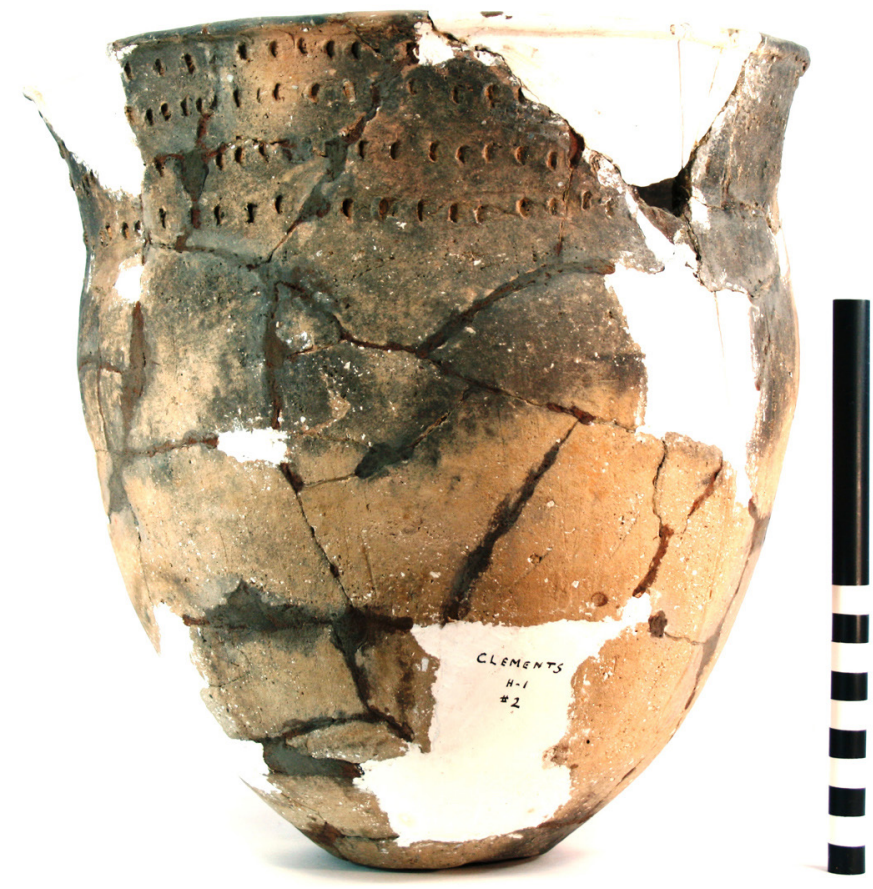

Figure 94. Mockingbird Punctated jar (Vessel No. 10) from Burial $\mathrm{H}-2$ at the Clements site.

DECORATION (INCLUDING MOTIF AND ELEMENTS WHEN APPARENT): There are four rows of tool punctations on the vessel rim (Figure 94)

PIGMENT USE AND LOCATION ON VESSEL: none

TYPE AND VARIETY (IF KNOWN): Mockingbird Punctated 
SITE NAME OR SITE NUMBER: Clements

VESSEL NO.: 15, Burial H-3

VESSEL FORM: Jar

NON-PLASTICS AND PASTE: bone

RIM AND LIP FORM: Everted rim and rounded lip

CORE COLOR: $\mathrm{F}$ (fired in a reducing environment and cooled in the open air)

INTERIOR SURFACE COLOR: reddish-brown; fire clouds on the rim and body; organic residue on the rim and body

EXTERIOR SURFACE COLOR: reddish-brown; fire clouds on the body

WALL THICKNESS (IN MM): rim, $5.3 \mathrm{~mm}$

INTERIOR SURFACE TREATMENT: smoothed

EXTERIOR SURFACE TREATMENT: none

HEIGHT (IN CM): 10.2

ORIFICE DIAMETER (IN CM): 11.5

DIAMETER AT BOTTOM OF RIM OR NECK

(IN CM): 9.9

BASE DIAMETER (IN CM) AND SHAPE OF

BASE: 5.1 ; circular and flat

ESTIMATED VOLUME (IN LITERS): 0.70

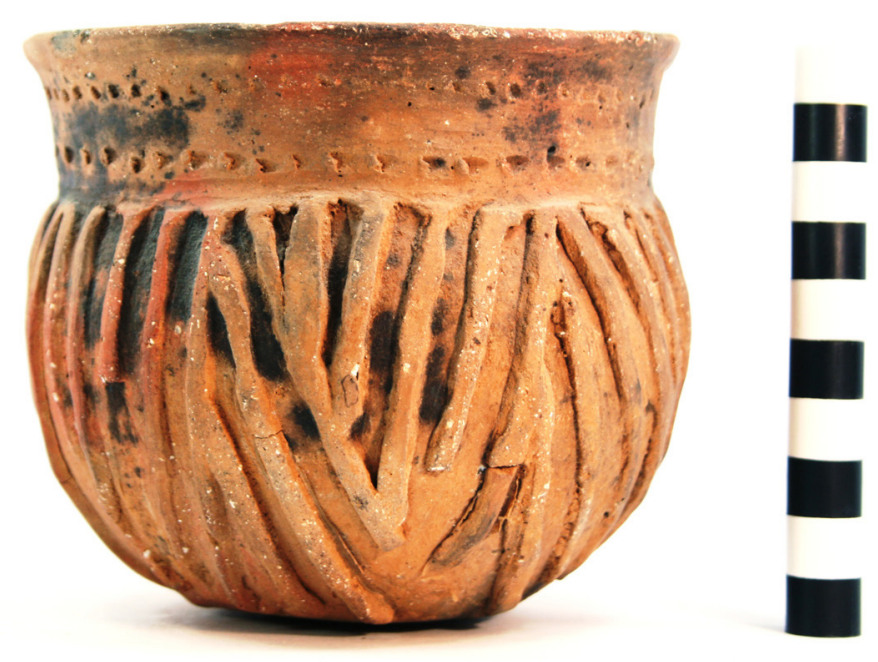

Figure 95. Cass Appliqued jar (Vessel No. 15) from Burial H-3 at the Clements site.

DECORATION (INCLUDING MOTIF AND ELEMENTS WHEN APPARENT): The rim is decorated with two rows of tool punctations, one row under the lip and the other at the rim-body juncture (Figure 95). There is also a broad but discontinuous horizontal incised line above the rim-body juncture. The vessel body has diagonal opposed appliqued ridges that extend from immediately below the rim-body juncture to the vessel base (Figure 95).

PIGMENT USE AND LOCATION ON VESSEL: none

TYPE AND VARIETY (IF KNOWN): Cass Appliqued 
SITE NAME OR SITE NUMBER: Clements

VESSEL NO.: 19, Burial H-4

VESSEL FORM: Jar

NON-PLASTICS AND PASTE: grog

RIM AND LIP FORM: Everted rim and rounded lip

CORE COLOR: A (fired and cooled in an oxidizing environment)

INTERIOR SURFACE COLOR: reddish-brown; fire clouds on the rim and body

EXTERIOR SURFACE COLOR: reddish-brown; fire clouds on the rim and body

WALL THICKNESS (IN MM): rim, $8.4 \mathrm{~mm}$

INTERIOR SURFACE TREATMENT: smoothed

EXTERIOR SURFACE TREATMENT: none

HEIGHT (IN CM): 29.0

ORIFICE DIAMETER (IN CM): 30.5

DIAMETER AT BOTTOM OF RIM OR NECK (IN CM): 28.0

BASE DIAMETER (IN CM) AND SHAPE OF

BASE: 8.0; circular and flat

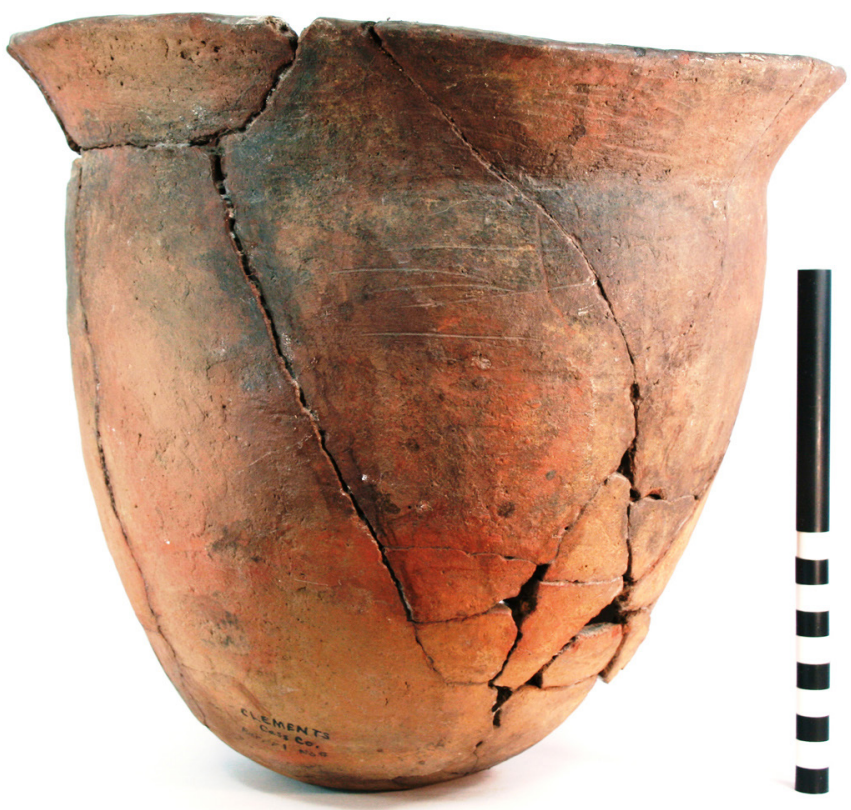

Figure 96. Brushed jar (Vessel No. 19) from Burial $\mathrm{H}-4$ at the Clements site.

ESTIMATED VOLUME (IN LITERS): 11.5

DECORATION (INCLUDING MOTIF AND ELEMENTS WHEN APPARENT): The rim and upper vessel body have horizontal brushing marks (Figure 96).

PIGMENT USE AND LOCATION ON VESSEL: none

TYPE AND VARIETY (IF KNOWN): Unidentified utility ware 
SITE NAME OR SITE NUMBER: Clements

VESSEL NO.: 20, Burial H-4

VESSEL FORM: Olla

NON-PLASTICS AND PASTE: grog

RIM AND LIP FORM: Everted rim and rounded lip

CORE COLOR: $\mathrm{F}$ (fired in a reducing environment and cooled in the open air)

INTERIOR SURFACE COLOR: yellowish-brown

EXTERIOR SURFACE COLOR: yellowishbrown; fire clouds on the rim, body, and base

WALL THICKNESS (IN MM): rim, $7.0 \mathrm{~mm}$

INTERIOR SURFACE TREATMENT: none

EXTERIOR SURFACE TREATMENT: smoothed on the lower body

HEIGHT (IN CM): 30.4

ORIFICE DIAMETER (IN CM): 9.5

DIAMETER AT BOTTOM OF RIM OR NECK (IN CM): 8.4

BASE DIAMETER (IN CM) AND SHAPE OF BASE: 8.3 ; circular and rounded

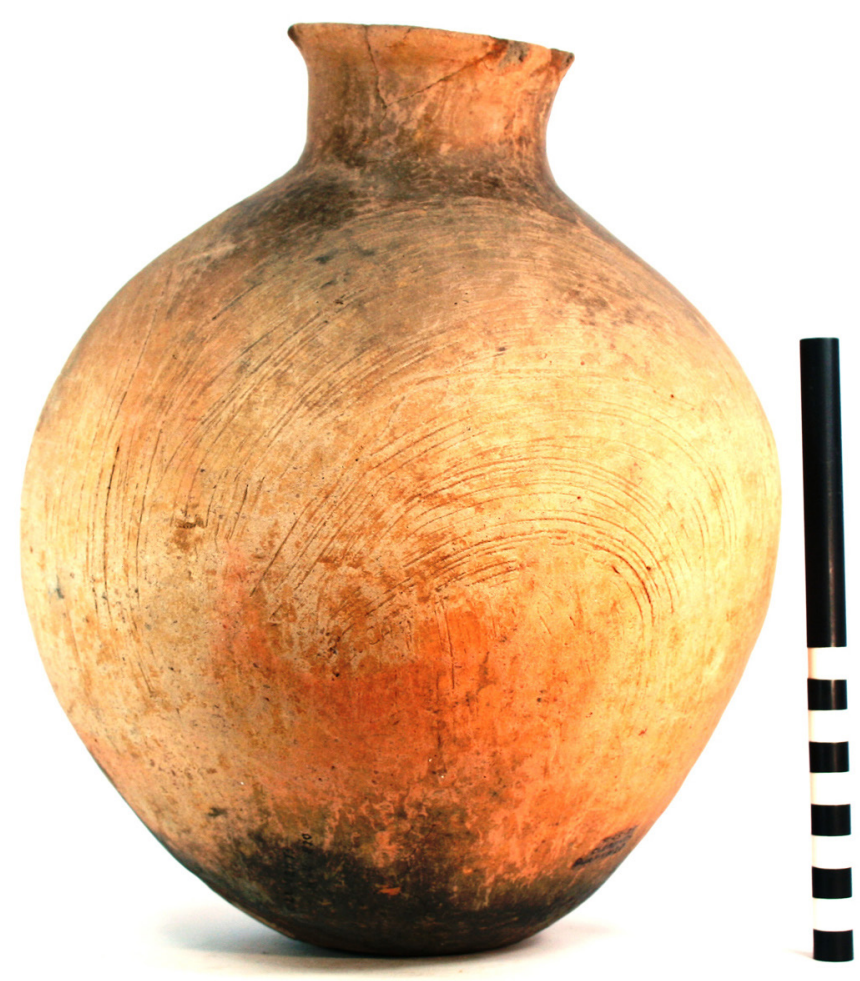

Figure 97. Clements Brushed olla (Vessel No. 20) from Burial $\mathrm{H}-4$ at the Clements site.

ESTIMATED VOLUME (IN LITERS): 2.0

DECORATION (INCLUDING MOTIF AND ELEMENTS WHEN APPARENT): There are curvilinear and vertical brushing marks on the body of the vessel (Figure 97).

PIGMENT USE AND LOCATION ON VESSEL: none

TYPE AND VARIETY (IF KNOWN): Clements Brushed 
SITE NAME OR SITE NUMBER: Clements

VESSEL NO.: 22, Burial H-4

VESSEL FORM: Jar

NON-PLASTICS AND PASTE: grog

RIM AND LIP FORM: Everted rim and rounded lip

CORE COLOR: $\mathrm{F}$ (fired in a reducing environment and cooled in the open air)

INTERIOR SURFACE COLOR: yellowishbrown; fire clouds on the rim and body

EXTERIOR SURFACE COLOR: yellowishbrown; fire clouds on the rim and body

WALL THICKNESS (IN MM): rim, 6.4 mm; body, $6.0 \mathrm{~mm}$

INTERIOR SURFACE TREATMENT: smoothed

EXTERIOR SURFACE TREATMENT: none

HEIGHT (IN CM): 18.4

ORIFICE DIAMETER (IN CM): 18.4

DIAMETER AT BOTTOM OF RIM OR NECK (IN CM): 17.8

BASE DIAMETER (IN CM) AND SHAPE OF BASE: N/A

ESTIMATED VOLUME (IN LITERS): 3.0

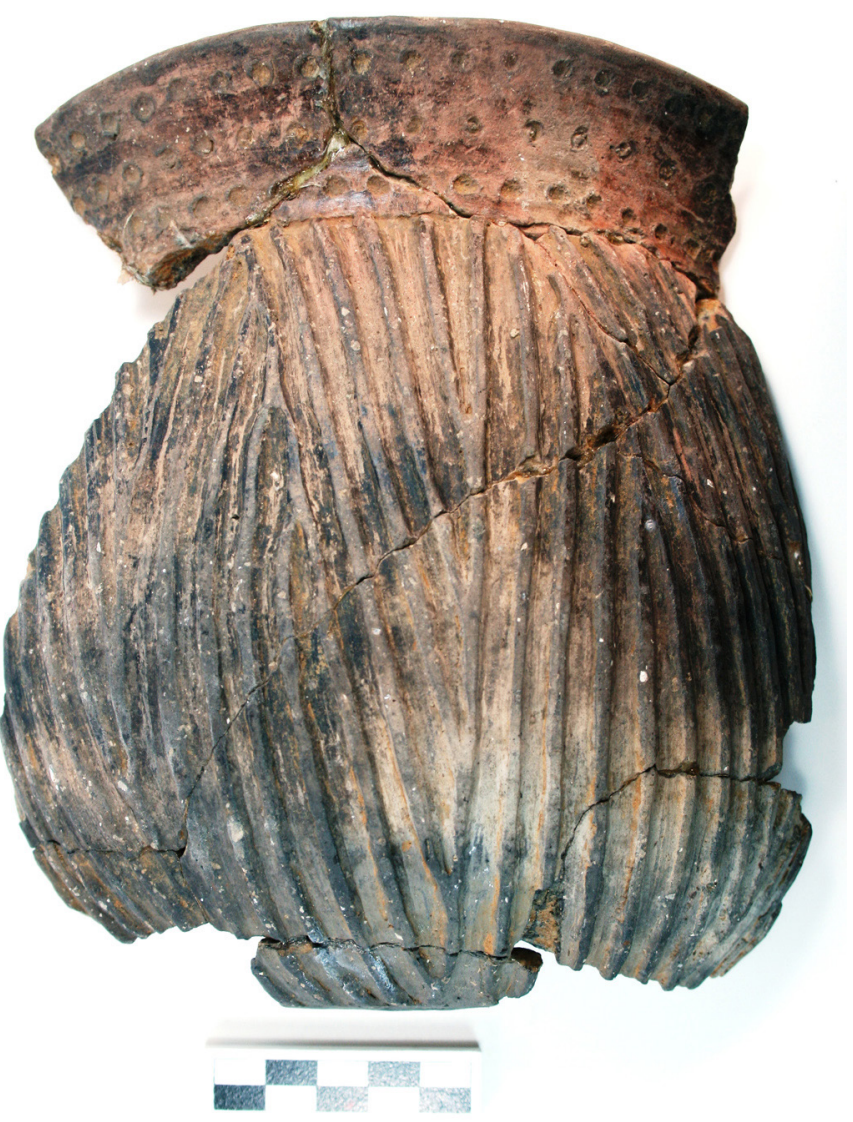

Figure 98. Cass Appliqued jar (Vessel No. 22) from Burial H-4 at the Clements site.

DECORATION (INCLUDING MOTIF AND ELEMENTS WHEN APPARENT): The vessel rim has three equally-spaced rows of circular punctations (Figure 98). The vessel body has vertical and diagonal opposed appliqued ridges that extend from the rim-body juncture to the vessel base (Figure 98).

PIGMENT USE AND LOCATION ON VESSEL: none

TYPE AND VARIETY (IF KNOWN): Cass Appliqued 
SITE NAME OR SITE NUMBER: Clements

VESSEL NO.: 26, Burial H-4

VESSEL FORM: Jar

NON-PLASTICS AND PASTE: bone

RIM AND LIP FORM: Everted rim and rounded lip

CORE COLOR: $\mathrm{F}$ (fired in a reducing environment and cooled in the open air)

INTERIOR SURFACE COLOR: yellowishbrown; fire clouds on the body

EXTERIOR SURFACE COLOR: yellowishbrown; fire clouds on the body

WALL THICKNESS (IN MM): rim, 6.7 mm; body, $7.2 \mathrm{~mm}$

INTERIOR SURFACE TREATMENT: smoothed

EXTERIOR SURFACE TREATMENT: none

HEIGHT (IN CM): N/A

ORIFICE DIAMETER (IN CM): N/A

DIAMETER AT BOTTOM OF RIM OR NECK (IN CM): N/A

BASE DIAMETER (IN CM) AND SHAPE OF BASE: N/A

ESTIMATED VOLUME (IN LITERS): N/A

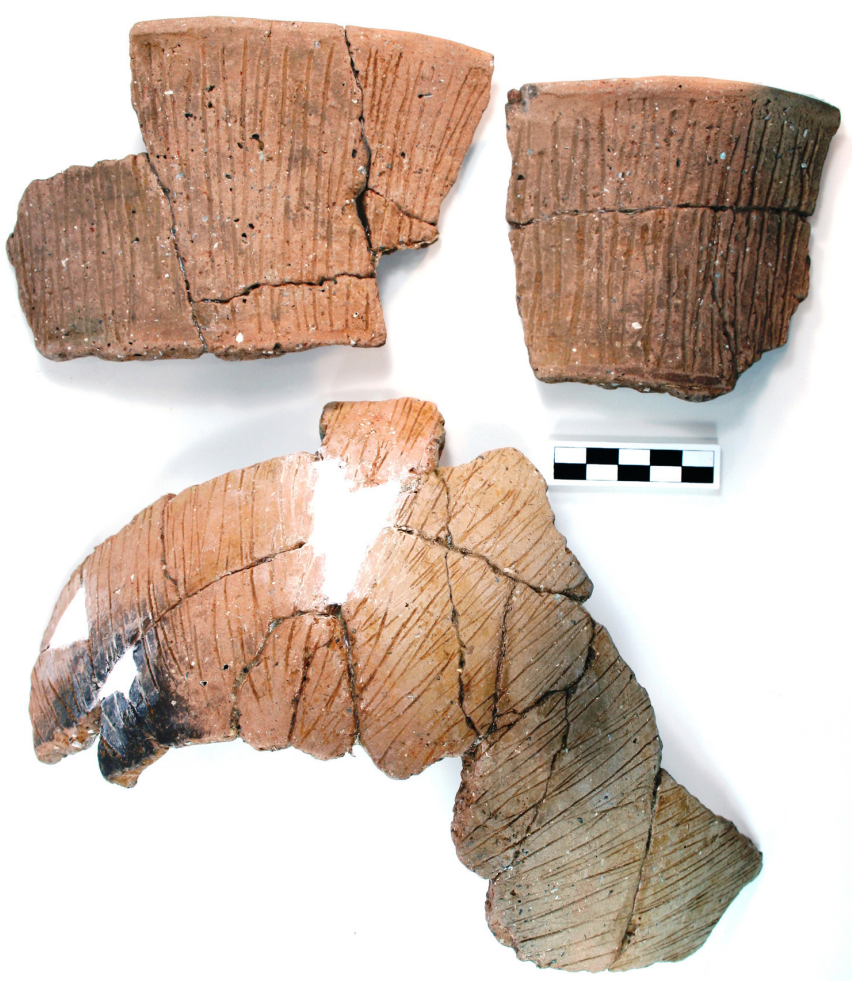

Figure 99. Karnack Brushed-Incised rim and body sherds (Vessel No. 26) from Burial H-4, Clements site.

DECORATION (INCLUDING MOTIF AND ELEMENTS WHEN APPARENT): The rim of the vessel has a continuous series of vertical incised lines. The vessel body has vertical brushed-incised marks and lines (Figure 99).

PIGMENT USE AND LOCATION ON VESSEL: none

TYPE AND VARIETY (IF KNOWN): Karnack Brushed-Incised 
SITE NAME OR SITE NUMBER: Clements

VESSEL NO.: 36, Burial H-6

VESSEL FORM: Jar

NON-PLASTICS AND PASTE: grog

RIM AND LIP FORM: Everted rim and rounded lip

CORE COLOR: $\mathrm{G}$ (fired in a reducing environment and cooled in the open air)

INTERIOR SURFACE COLOR: dark grayish-brown

EXTERIOR SURFACE COLOR: dark reddish-

brown; fire clouds on the body

WALL THICKNESS (IN MM): rim, $5.6 \mathrm{~mm}$

INTERIOR SURFACE TREATMENT: smoothed

EXTERIOR SURFACE TREATMENT: none

HEIGHT (IN CM): 8.8

ORIFICE DIAMETER (IN CM): 7.8

DIAMETER AT BOTTOM OF RIM OR NECK (IN CM): 6.8

BASE DIAMETER (IN CM) AND SHAPE OF

BASE: 5.1; circular and rounded

ESTIMATED VOLUME (IN LITERS): 0.41

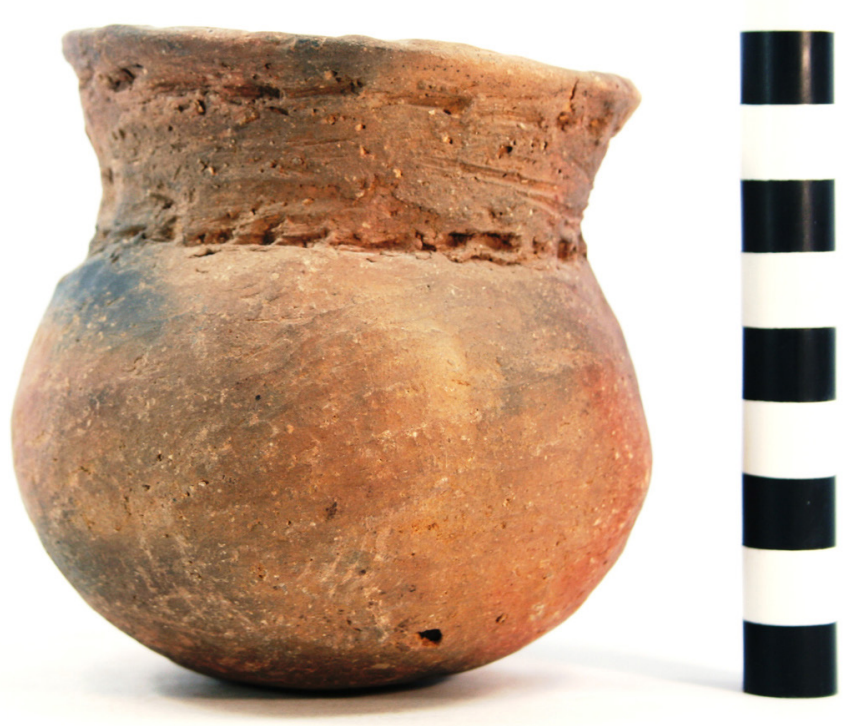

Figure 100. Brushed-punctated jar (Vessel No. 36) from Burial H-6 at the Clements site.

DECORATION (INCLUDING MOTIF AND ELEMENTS WHEN APPARENT): The rim has a row of tool punctations under the lip and another at the rim-body juncture. Between the two rows of punctations are horizontal brushing marks (Figure 100).

PIGMENT USE AND LOCATION ON VESSEL: none

TYPE AND VARIETY (IF KNOWN): Unidentified utility ware 
SITE NAME OR SITE NUMBER: Clements

VESSEL NO.: 37, Burial H-6

VESSEL FORM: Compound bowl with a tall upper panel; there are two opposed suspension holes (4.0 mm in diameter) below the lip (Figure 101)

NON-PLASTICS AND PASTE: grog

RIM AND LIP FORM: Direct rim and rounded lip

CORE COLOR: B (fired and cooled in a reducing environment)

INTERIOR SURFACE COLOR: very dark grayish-brown

EXTERIOR SURFACE COLOR: very dark gray

WALL THICKNESS (IN MM): rim, $5.6 \mathrm{~mm}$

INTERIOR SURFACE TREATMENT: smoothed on the upper panel

EXTERIOR SURFACE TREATMENT: burnished HEIGHT (IN CM): 13.4

ORIFICE DIAMETER (IN CM): 9.5 (at base of the upper panel); 11.4 (at base of the lower panel)

DIAMETER AT BOTTOM OF RIM OR NECK (IN CM): 10.9

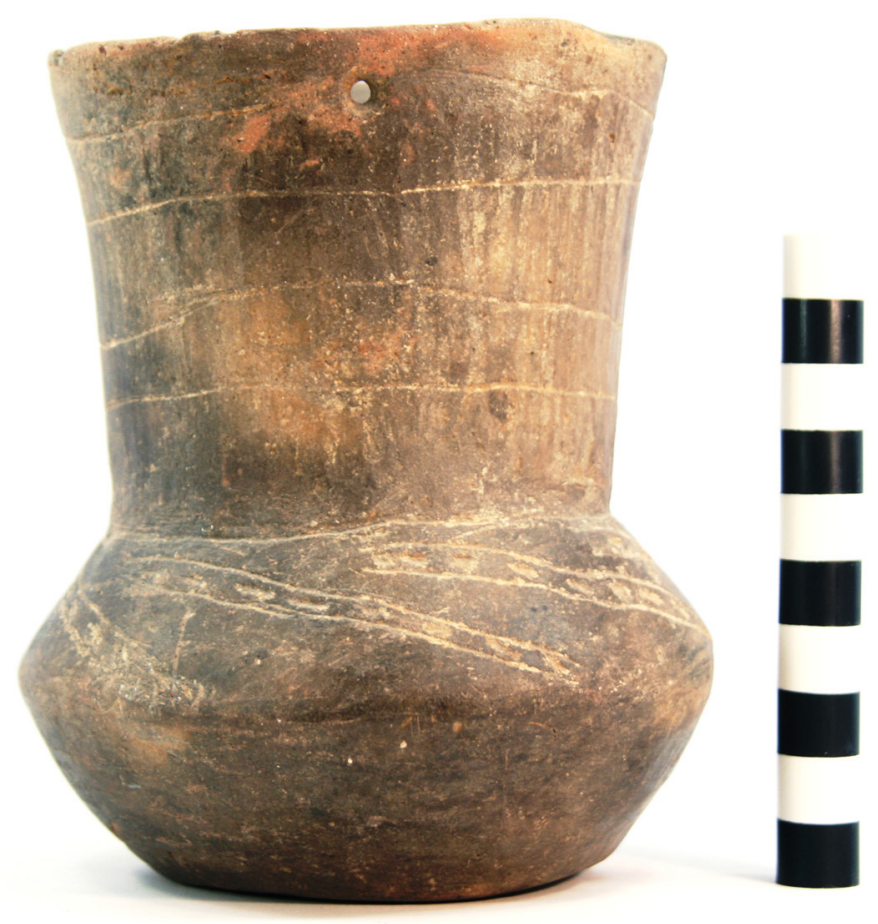

Figure 101. Engraved-punctated compound bowl (Vessel No. 37) from Burial H-6 at the Clements site.

BASE DIAMETER (IN CM) AND SHAPE OF BASE: 7.1; circular and flat

ESTIMATED VOLUME (IN LITERS): 1.1

DECORATION (INCLUDING MOTIF AND ELEMENTS WHEN APPARENT): The upper panel has five widely-spaced horizontal engraved lines (Figure 101). The lower panel has a series of seven narrow diagonal engraved zones filled with excised punctations.

PIGMENT USE AND LOCATION ON VESSEL: none

TYPE AND VARIETY (IF KNOWN): Unidentified fine ware 
SITE NAME OR SITE NUMBER: Clements

VESSEL NO.: 38, Burial H-6

VESSEL FORM: Jar

NON-PLASTICS AND PASTE: bone

RIM AND LIP FORM: Everted rim and rounded lip

CORE COLOR: F (fired in a reducing environment and cooled in the open air)

INTERIOR SURFACE COLOR: dark yellowish-brown; fire clouds on the rim and body

EXTERIOR SURFACE COLOR: yellowishbrown; fire clouds on the rim, body, and base

WALL THICKNESS (IN MM): rim, $5.7 \mathrm{~mm}$; body, $6.5 \mathrm{~mm}$

INTERIOR SURFACE TREATMENT: smoothed

EXTERIOR SURFACE TREATMENT: none

HEIGHT (IN CM): 12.7

ORIFICE DIAMETER (IN CM): 10.9

DIAMETER AT BOTTOM OF RIM OR NECK (IN CM): 10.2

BASE DIAMETER (IN CM) AND SHAPE OF

BASE: 7.0; circular and flat

ESTIMATED VOLUME (IN LITERS): 0.85

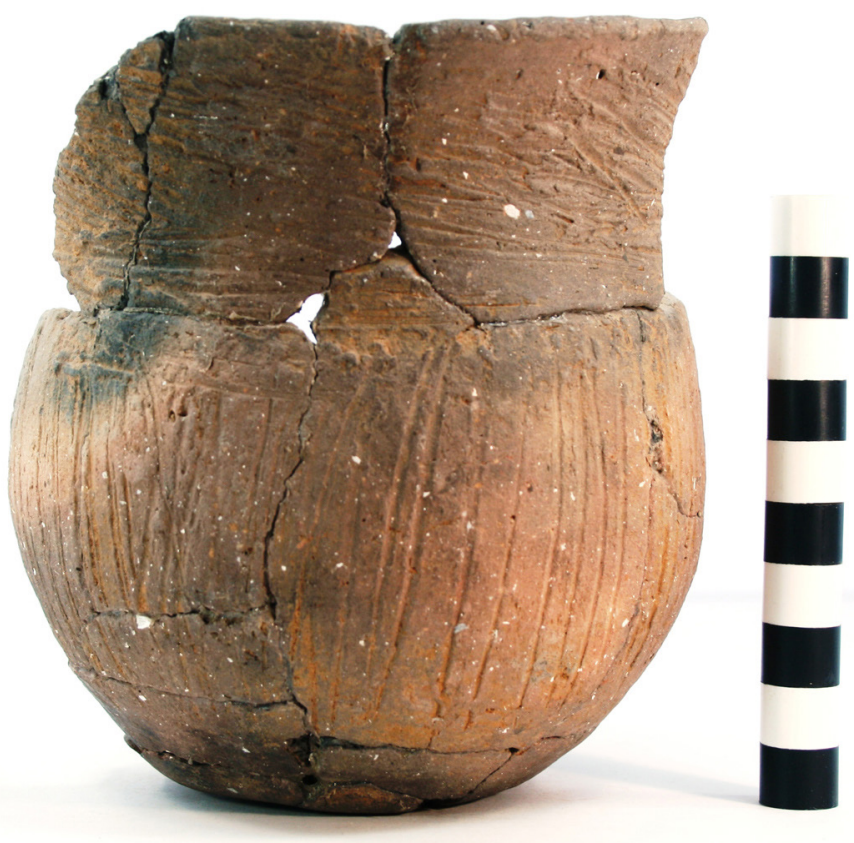

Figure 102. Karnack Brushed-Incised jar (Vessel No. 38) from Burial H-6 at the Clements site.

DECORATION (INCLUDING MOTIF AND ELEMENTS WHEN APPARENT): The rim has horizontal brushing marks (Figure 102). There are vertical brushed-incised marks and lines on the vessel body, and these extend to within $2.0 \mathrm{~cm}$ of the base.

PIGMENT USE AND LOCATION ON VESSEL: none

TYPE AND VARIETY (IF KNOWN): Karnack Brushed-Incised 
SITE NAME OR SITE NUMBER: Clements

VESSEL NO.: 42, Burial H-7

VESSEL FORM: Carinated bowl, hubcap style (Figure 103)

NON-PLASTICS AND PASTE: grog

RIM AND LIP FORM: Inverted and direct rim, rounded lip

CORE COLOR: F (fired in a reducing environment and cooled in the open air)

INTERIOR SURFACE COLOR: dark reddish-brown

EXTERIOR SURFACE COLOR: reddish-brown

WALL THICKNESS (IN MM): rim, $5.4 \mathrm{~mm}$

INTERIOR SURFACE TREATMENT: smoothed

EXTERIOR SURFACE TREATMENT: burnished

HEIGHT (IN CM): 15.3

ORIFICE DIAMETER (IN CM): 25.2

DIAMETER AT BOTTOM OF RIM OR NECK

(IN CM): 26.0

BASE DIAMETER (IN CM) AND SHAPE OF

BASE: 7.0; circular and flat

ESTIMATED VOLUME (IN LITERS): 3.5

DECORATION (INCLUDING MOTIF AND ELEMENTS WHEN APPARENT): There are four engraved panels on the rim, with each panel divided by two opposed curvilinear lines and vertical hatched brackets. The upper and lower horizontal lines on the panel have small and downward-pointing excised tick marks, and the panel is bisected by another horizontal engraved line with downward-pointing excised tick marks (Figure 103).

PIGMENT USE AND LOCATION ON VESSEL: none

TYPE AND VARIETY (IF KNOWN): Simms Engraved 
SITE NAME OR SITE NUMBER: Clements

VESSEL NO.: 62, Burial H-8

VESSEL FORM: Jar

NON-PLASTICS AND PASTE: grog

RIM AND LIP FORM: Everted rim and rounded lip

CORE COLOR: F (fired in a reducing environment and cooled in the open air)

INTERIOR SURFACE COLOR: dark yellowish-brown; fire clouds on the rim and body

EXTERIOR SURFACE COLOR: dark yellowishbrown; fire clouds on the rim, body, and base; organic residue on the body

WALL THICKNESS (IN MM): rim, $4.9 \mathrm{~mm}$

INTERIOR SURFACE TREATMENT: smoothed

EXTERIOR SURFACE TREATMENT: none

HEIGHT (IN CM): 9.4

ORIFICE DIAMETER (IN CM): 9.6

DIAMETER AT BOTTOM OF RIM OR NECK (IN CM): 7.6

BASE DIAMETER (IN CM) AND SHAPE OF

BASE: 2.6; circular and flat

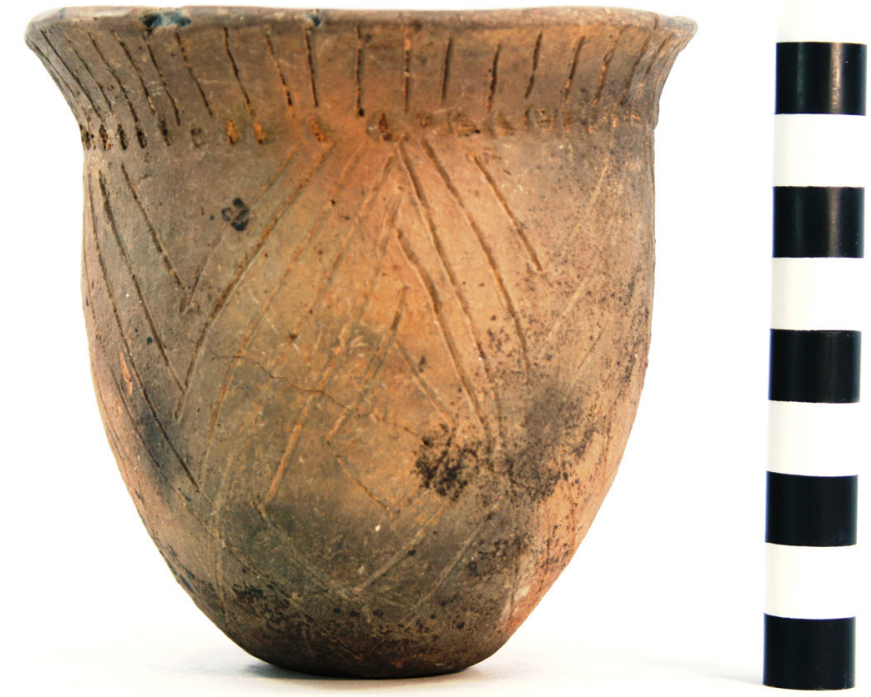

Figure 104. Incised-punctated jar (Vessel No. 62) from Burial $\mathrm{H}-8$ at the Clements site.

ESTIMATED VOLUME (IN LITERS): 0.54

DECORATION (INCLUDING MOTIF AND ELEMENTS WHEN APPARENT): The vessel rim has a continuous series of vertical incised lines above a row of tool punctations at the rim-body juncture (Figure 104). The vessel body has a series of four nested diagonal opposed triangles and diamond elements.

PIGMENT USE AND LOCATION ON VESSEL: none

TYPE AND VARIETY (IF KNOWN): Unidentified utility ware 
SITE NAME OR SITE NUMBER: Clements

VESSEL NO.: 70, Burial H-11

VESSEL FORM: Olla with a spool neck

NON-PLASTICS AND PASTE: grog

RIM AND LIP FORM: Everted rim and rounded lip

CORE COLOR: $\mathrm{F}$ (fired in a reducing

environment and cooled in the open air)

INTERIOR SURFACE COLOR: reddish-brown

EXTERIOR SURFACE COLOR: reddish-brown to brown

WALL THICKNESS (IN MM): rim, 6.4 mm

INTERIOR SURFACE TREATMENT: none

EXTERIOR SURFACE TREATMENT: burnished

HEIGHT (IN CM): 30.7

ORIFICE DIAMETER (IN CM): 8.9

DIAMETER AT BOTTOM OF RIM OR NECK

(IN CM): 8.3

BASE DIAMETER (IN CM) AND SHAPE OF

BASE: 8.3; circular and flat

ESTIMATED VOLUME (IN LITERS): 2.0

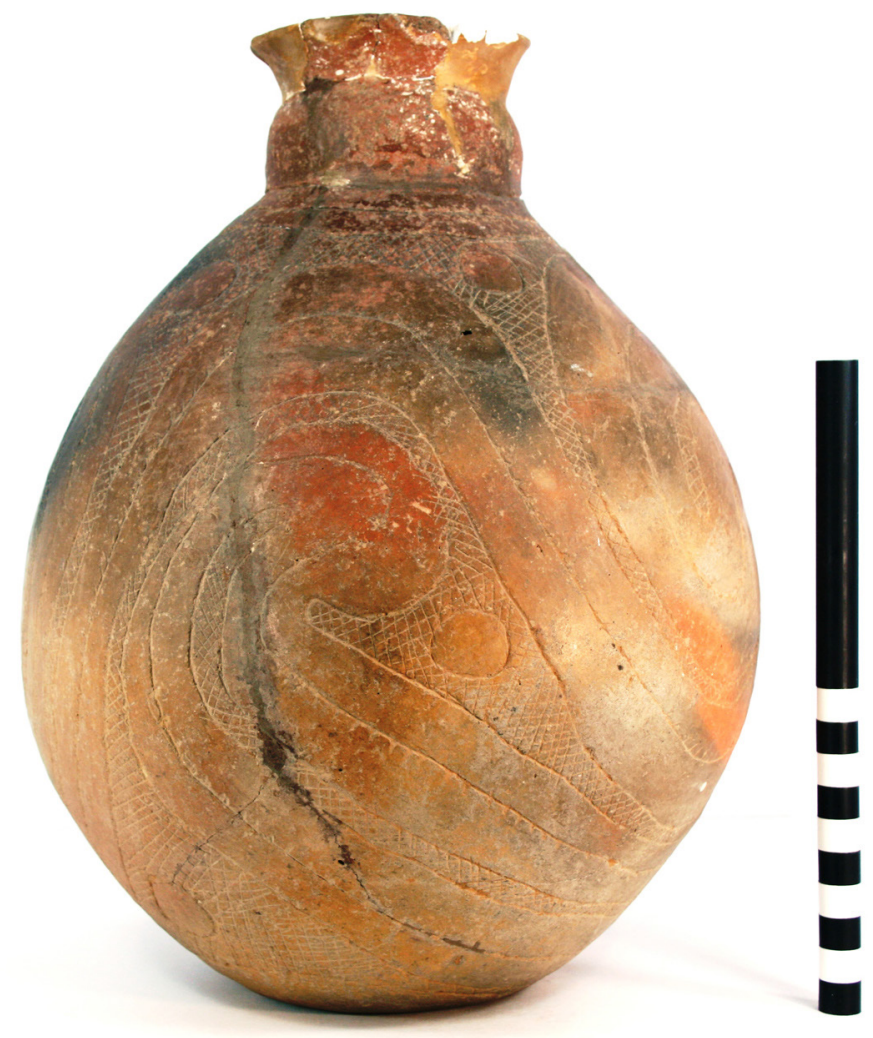

Figure 105. Hodges Engraved olla (Vessel No. 70) from Burial $\mathrm{H}-11$ at the Clements site.

DECORATION (INCLUDING MOTIF AND ELEMENTS WHEN APPARENT): The upper part of the vessel body has three horizontal engraved lines, while the remainder of the vessel body has four meandering and hooked arm scroll elements outlined by a number of cross-hatched zones and curvilinear scroll lines with linear tick marks (Figure 105). The cross-hatched zones have negative circles within them.

PIGMENT USE AND LOCATION ON VESSEL: none

TYPE AND VARIETY (IF KNOWN): Hodges Engraved 
SITE NAME OR SITE NUMBER: Clements

VESSEL NO.: 71, Burial H-11

VESSEL FORM: Carinated bowl; hubcap style (Figure 106)

NON-PLASTICS AND PASTE: shell

RIM AND LIP FORM: Inverted and direct rim and rounded lip

CORE COLOR: B (fired and cooled in a reducing environment)

INTERIOR SURFACE COLOR: black

EXTERIOR SURFACE COLOR: very dark gray; fire clouds on the rim and body

WALL THICKNESS (IN MM): rim, $4.8 \mathrm{~mm}$

INTERIOR SURFACE TREATMENT: smoothed

EXTERIOR SURFACE TREATMENT: burnished

HEIGHT (IN CM): 9.4

ORIFICE DIAMETER (IN CM): 14.6

DIAMETER AT BOTTOM OF RIM OR NECK (IN CM): 16.5

BASE DIAMETER (IN CM) AND SHAPE OF BASE: 7.6; circular and rounded

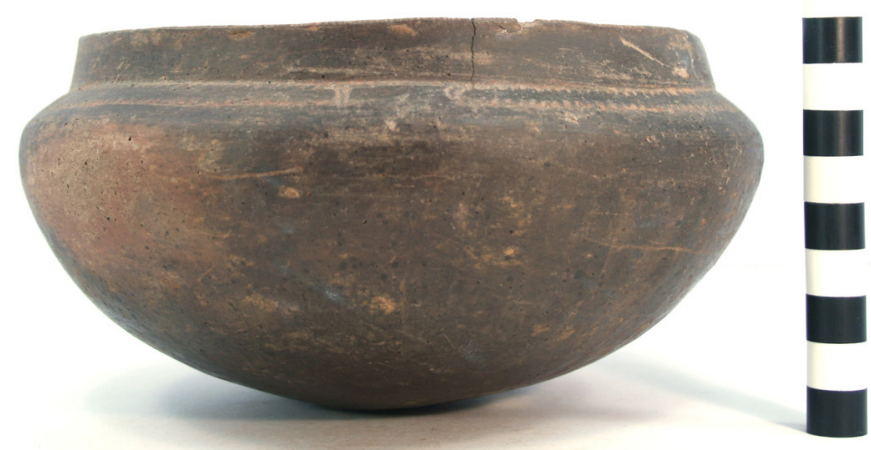

Figure 106. Simms Engraved carinated bowl (Vessel No. 71) from Burial $\mathrm{H}-11$ at the Clements site.

ESTIMATED VOLUME (IN LITERS): 0.82

DECORATION (INCLUDING MOTIF AND ELEMENTS WHEN APPARENT): The lower half of the rim has four sets of engraved panels (Figure 106). The panels are divided by two opposed sets of curvilinear lines forming large bracket elements. The upper and lower panels are defined by horizontal engraved lines with either upwards or downwards-pointing excised tick marks.

PIGMENT USE AND LOCATION ON VESSEL: none

TYPE AND VARIETY (IF KNOWN): Simms Engraved 
SITE NAME OR SITE NUMBER: Clements

VESSEL NO.: 73, Burial H-11

VESSEL FORM: Carinated bowl

NON-PLASTICS AND PASTE: grog and bone

RIM AND LIP FORM: Direct rim and rounded lip; lip notched

CORE COLOR: F (fired in a reducing environment and cooled in the open air)

INTERIOR SURFACE COLOR: reddish-brown

EXTERIOR SURFACE COLOR: reddish-brown; fire clouds on the rim, body, and base

WALL THICKNESS (IN MM): rim, $4.2 \mathrm{~mm}$

INTERIOR SURFACE TREATMENT: smoothed

EXTERIOR SURFACE TREATMENT: burnished

HEIGHT (IN CM): 6.6

ORIFICE DIAMETER (IN CM): 14.0

DIAMETER AT BOTTOM OF RIM OR NECK

(IN CM): 13.6

BASE DIAMETER (IN CM) AND SHAPE OF

BASE: 5.7; circular and rounded

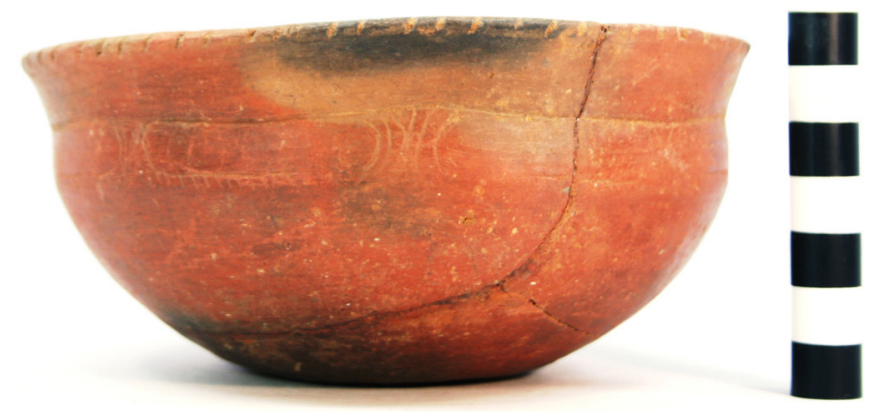

Figure 107. Simms Engraved carinated bowl (Vessel No. 73) in Burial H-11 at the Clements site.

ESTIMATED VOLUME (IN LITERS): 0.54

DECORATION (INCLUDING MOTIF AND ELEMENTS WHEN APPARENT): The lower part of the rim has a series of seven engraved panels. These panels have either one or two horizontal engraved lines with downward-pointing tick marks on them (Figure 107). The panels are divided by either free-standing brackets $(n=4)$ with curvilinear and vertical hatched lines or brackets $(n=3)$, also with curvilinear and vertical hatched lines, that are connected to the horizontal engraved lines in the panels.

PIGMENT USE AND LOCATION ON VESSEL: none

TYPE AND VARIETY (IF KNOWN): Simms Engraved 
SITE NAME OR SITE NUMBER: Clements

VESSEL NO.: 74, Burial H-11

VESSEL FORM: Bowl with two rim peaks or tab tails (Figure 108)

NON-PLASTICS AND PASTE: grog and bone

RIM AND LIP FORM: Direct rim and rounded lip

CORE COLOR: B (fired and cooled in a reducing environment)

INTERIOR SURFACE COLOR: dark gray

EXTERIOR SURFACE COLOR: dark gray; fire clouds on the rim and body

WALL THICKNESS (IN MM): rim, $5.1 \mathrm{~mm}$

INTERIOR SURFACE TREATMENT: smoothed

EXTERIOR SURFACE TREATMENT: smoothed

HEIGHT (IN CM): 5.1

ORIFICE DIAMETER (IN CM): 10.3

DIAMETER AT BOTTOM OF RIM OR NECK

(IN CM): N/A

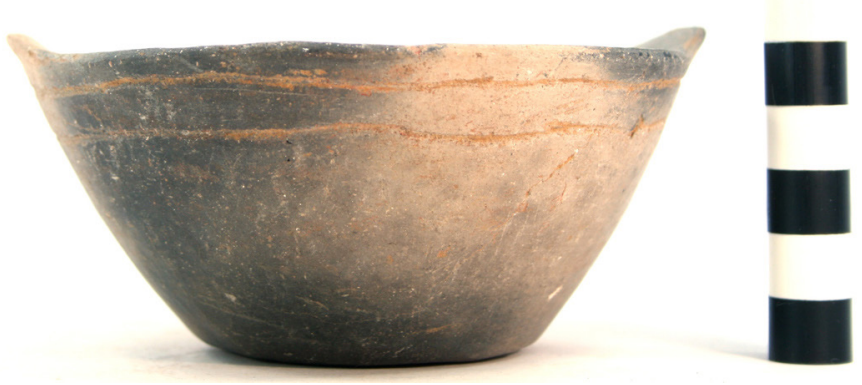

Figure 108. Engraved bowl (Vessel No. 74) from Burial H-11 at the Clements site.

BASE DIAMETER (IN CM) AND SHAPE OF BASE: 5.1; circular and flat

ESTIMATED VOLUME (IN LITERS): 0.21

DECORATION (INCLUDING MOTIF AND ELEMENTS WHEN APPARENT): There are two horizontal engraved lines on the vessel below the lip (Figure 108).

PIGMENT USE AND LOCATION ON VESSEL: none

TYPE AND VARIETY (IF KNOWN): Unidentified fine ware 
SITE NAME OR SITE NUMBER: Clements

VESSEL NO.: 77, Burial H-11

VESSEL FORM: Jar

NON-PLASTICS AND PASTE: shell

RIM AND LIP FORM: Everted rim and rounded lip

CORE COLOR: $\mathrm{F}$ (fired in a reducing environment and cooled in the open air)

INTERIOR SURFACE COLOR: dark yellowishbrown; fire clouds on the rim and body

EXTERIOR SURFACE COLOR: yellowishbrown; fire clouds on the rim and body

WALL THICKNESS (IN MM): rim, $5.7 \mathrm{~mm}$; body, $5.9 \mathrm{~mm}$

INTERIOR SURFACE TREATMENT: smoothed

EXTERIOR SURFACE TREATMENT: smoothed on the body

HEIGHT (IN CM): 19.5

ORIFICE DIAMETER (IN CM): 12.7

DIAMETER AT BOTTOM OF RIM OR NECK (IN CM): 9.9

BASE DIAMETER (IN CM) AND SHAPE OF BASE: 7.1; circular and flat

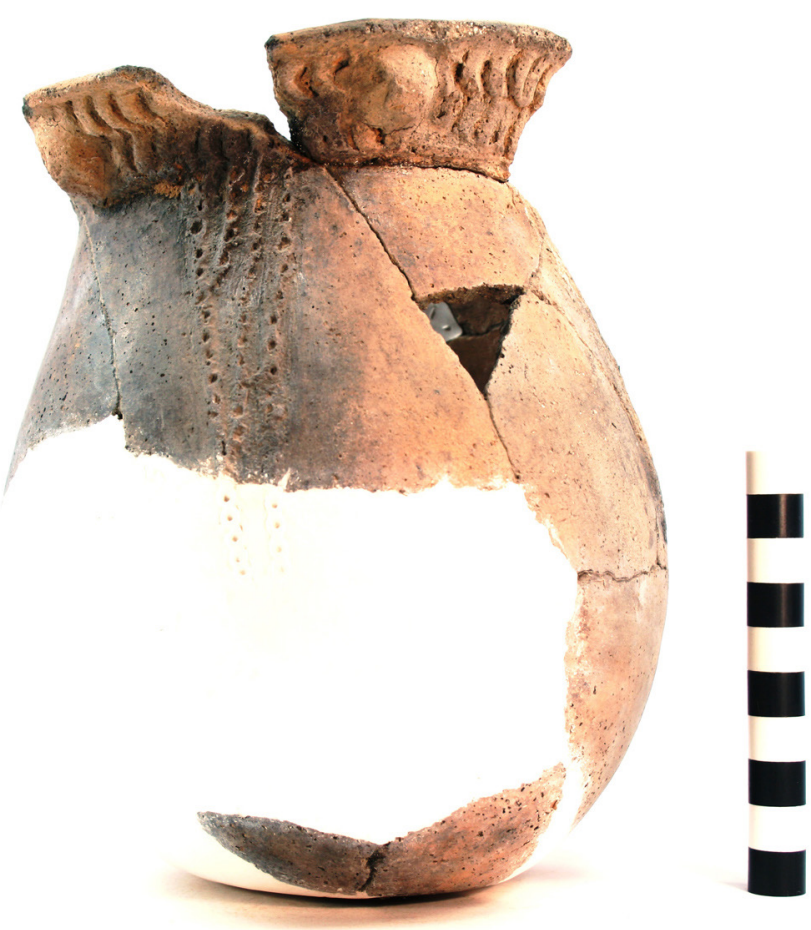

Figure 109. Nash Neck Banded jar (Vessel No. 77) from Burial H-11 at the Clements site.

ESTIMATED VOLUME (IN LITERS): 2.2

DECORATION (INCLUDING MOTIF AND ELEMENTS WHEN APPARENT): The vessel rim has two rows of horizontal neck bands and two or more large circular appliqued nodes (Figure 109). The vessel body has four sets of three vertical appliqued fillets; these are centered on the body below and between the large appliqued nodes on the rim.

PIGMENT USE AND LOCATION ON VESSEL: none

TYPE AND VARIETY (IF KNOWN): Nash Neck Banded 
SITE NAME OR SITE NUMBER: Clements

VESSEL NO.: 79, Burial H-11

VESSEL FORM: Jar with four rim peaks (Figure 110)

NON-PLASTICS AND PASTE: grog

RIM AND LIP FORM: Everted rim and rounded lip

CORE COLOR: B (fired and cooled in a reducing environment)

INTERIOR SURFACE COLOR: black

EXTERIOR SURFACE COLOR: black

WALL THICKNESS (IN MM): rim, 4.6 mm

INTERIOR SURFACE TREATMENT: smoothed on the rim

EXTERIOR SURFACE TREATMENT: smoothed on the body

HEIGHT (IN CM): 7.6

ORIFICE DIAMETER (IN CM): 9.3

DIAMETER AT BOTTOM OF RIM OR NECK (IN CM): 8.7

BASE DIAMETER (IN CM) AND SHAPE OF

BASE: 5.4; circular and flat

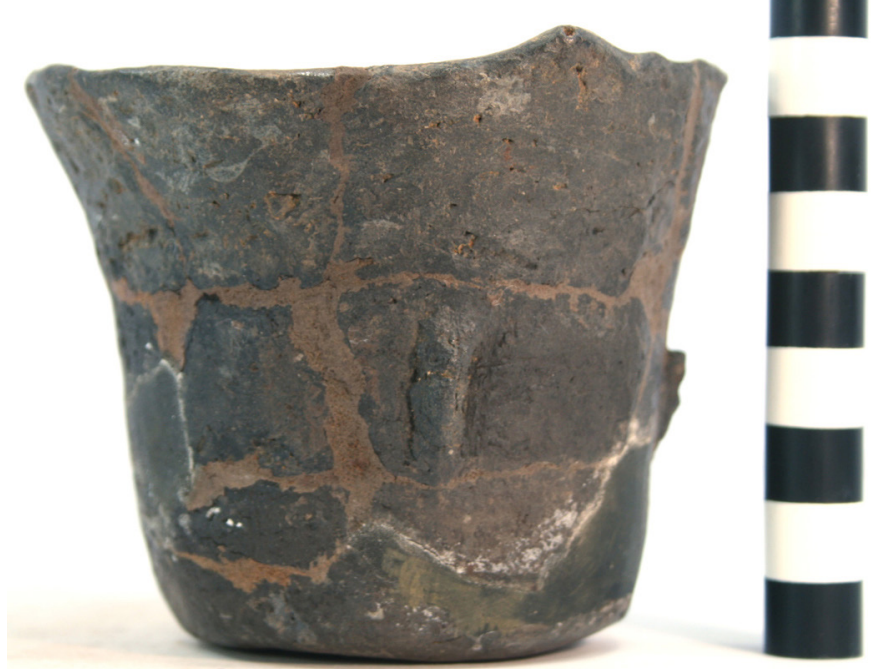

Figure 110. Appliqued jar (Vessel No. 79) from Burial $\mathrm{H}-11$ at the Clements site.

ESTIMATED VOLUME (IN LITERS): 0.42

DECORATION (INCLUDING MOTIF AND ELEMENTS WHEN APPARENT): The vessel rim is plain, but the vessel body has four short vertical appliqued ridges that extend from the rim-body juncture to the mid-body (Figure 110).

PIGMENT USE AND LOCATION ON VESSEL: none

TYPE AND VARIETY (IF KNOWN): Unidentified utility ware 
SITE NAME OR SITE NUMBER: Clements

VESSEL NO.: 80, Burial H-12

VESSEL FORM: Bowl

NON-PLASTICS AND PASTE: grog

RIM AND LIP FORM: Direct rim and rounded lip

CORE COLOR: F (fired in a reducing environment and cooled in the open air)

INTERIOR SURFACE COLOR: yellowish-brown; fire clouds on the rim, body, and base

EXTERIOR SURFACE COLOR: yellowish-

brown; fire clouds on the rim, body, and base

WALL THICKNESS (IN MM): rim, $5.6 \mathrm{~mm}$

INTERIOR SURFACE TREATMENT: none

EXTERIOR SURFACE TREATMENT: none

HEIGHT (IN CM): 3.1

ORIFICE DIAMETER (IN CM): 7.2

DIAMETER AT BOTTOM OF RIM OR NECK

(IN CM): N/A

BASE DIAMETER (IN CM) AND SHAPE OF

BASE: 4.3; circular and rounded
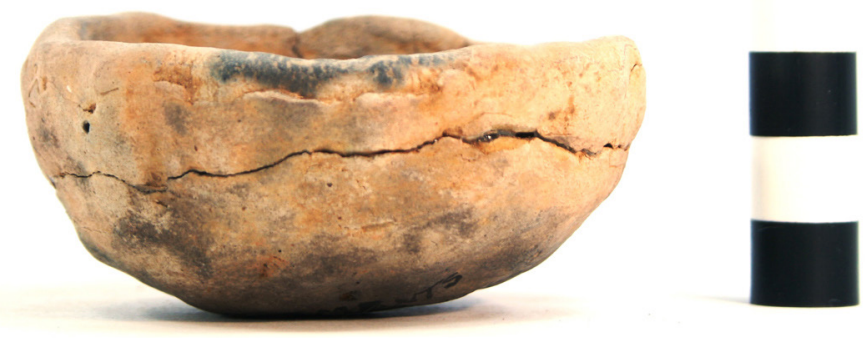

Figure 111. Plain bowl (Vessel No. 80) from Burial

ESTIMATED VOLUME (IN LITERS): 0.09

H-12 at the Clements site.

DECORATION (INCLUDING MOTIF AND ELEMENTS WHEN APPARENT): Plain (Figure 111)

PIGMENT USE AND LOCATION ON VESSEL: none

TYPE AND VARIETY (IF KNOWN): Unidentified plain ware 
SITE NAME OR SITE NUMBER: Clements

VESSEL NO.: 81, Burial H-12

VESSEL FORM: Carinated bowl

NON-PLASTICS AND PASTE: grog

RIM AND LIP FORM: Inverted rim and rounded lip

CORE COLOR: $\mathrm{G}$ (fired in a reducing environment and cooled in the open air)

INTERIOR SURFACE COLOR: dark grayish-brown

EXTERIOR SURFACE COLOR: strong brown; fire clouds on the rim, body, and base

WALL THICKNESS (IN MM): rim, 6.4 mm

INTERIOR SURFACE TREATMENT: smoothed

EXTERIOR SURFACE TREATMENT: burnished

HEIGHT (IN CM): 13.3

ORIFICE DIAMETER (IN CM): 22.1

DIAMETER AT BOTTOM OF RIM OR NECK (IN CM): 20.9

BASE DIAMETER (IN CM) AND SHAPE OF BASE: 7.6; circular and flat

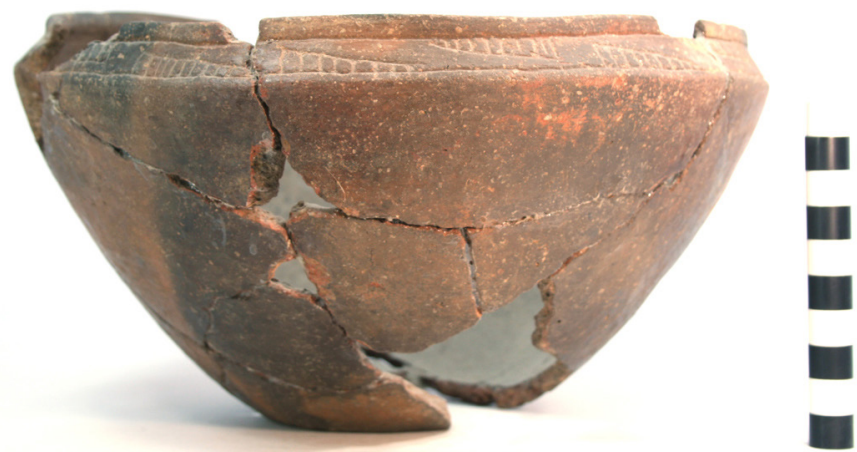

ESTIMATED VOLUME (IN LITERS): 2.6

Figure 112. Simms Engraved carinated bowl (Vessel No. 81) in Burial H-12 at the Clements site.

DECORATION (INCLUDING MOTIF AND ELEMENTS WHEN APPARENT): The rim panel has seven engraved upper and lower scroll fill zones on either side of a negative or empty meandering scroll (Figure 112). Each of the scroll fill zones is filled with vertical hatched engraved lines.

PIGMENT USE AND LOCATION ON VESSEL: none

TYPE AND VARIETY (IF KNOWN): Simms Engraved 
SITE NAME OR SITE NUMBER: Clements

VESSEL NO.: 95, Burial H-14

VESSEL FORM: Deep Bowl

NON-PLASTICS AND PASTE: grog and shell

RIM AND LIP FORM: Everted rim and rounded lip

CORE COLOR: $\mathrm{F}$ (fired in a reducing environment and cooled in the open air)

INTERIOR SURFACE COLOR: red

EXTERIOR SURFACE COLOR: red

WALL THICKNESS (IN MM): $\operatorname{rim}, 5.2 \mathrm{~mm}$

INTERIOR SURFACE TREATMENT: smoothed

EXTERIOR SURFACE TREATMENT: burnished

HEIGHT (IN CM): 12.5

ORIFICE DIAMETER (IN CM): 16.5

DIAMETER AT BOTTOM OF RIM OR NECK

(IN CM): 14.2

BASE DIAMETER (IN CM) AND SHAPE OF

BASE: 5.7; circular and flat

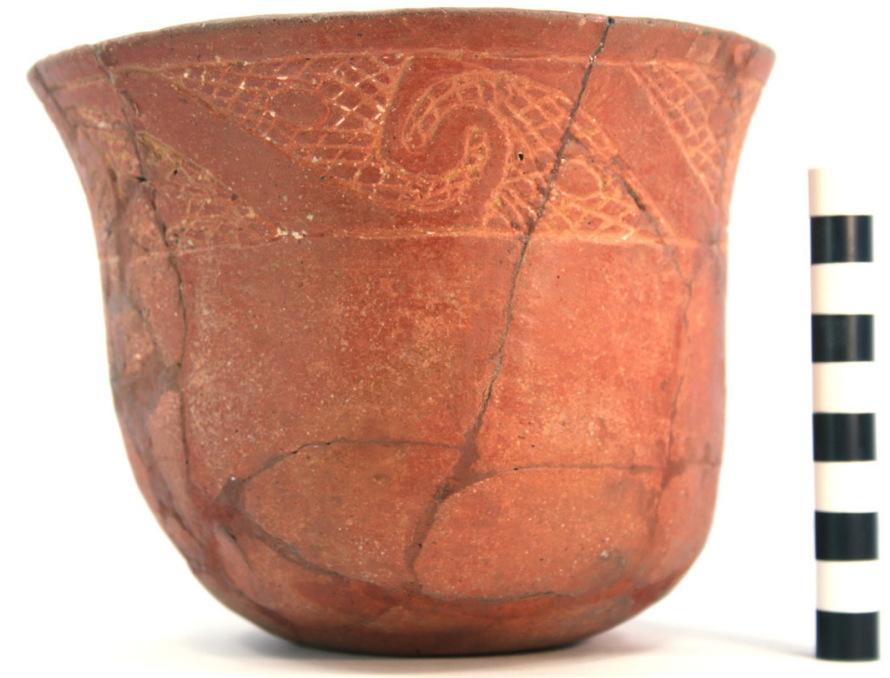

Figure 113. Hodges Engraved deep bowl (Vessel No. 95) in Burial H-14 at the Clements site.

ESTIMATED VOLUME (IN LITERS): 1.6

DECORATION (INCLUDING MOTIF AND ELEMENTS WHEN APPARENT): The vessel has a red slip on both interior and exterior surfaces. It is decorated with a series of five upper and lower curvilinear zones with hooked arm elements (Figure 113). The engraved zones each have a negative circle outlined by crosshatched engraved lines that fill the zones.

PIGMENT USE AND LOCATION ON VESSEL: none

TYPE AND VARIETY (IF KNOWN): Hodges Engraved 
SITE NAME OR SITE NUMBER: Clements

VESSEL NO.: 96, Burial H-14

VESSEL FORM: Jar

NON-PLASTICS AND PASTE: grog and bone

RIM AND LIP FORM: Everted rim and rounded lip; lip notched

CORE COLOR: F (fired in a reducing environment and cooled in the open air)

INTERIOR SURFACE COLOR: dark reddish-brown

EXTERIOR SURFACE COLOR: reddish-brown; fire clouds on the rim and body

WALL THICKNESS (IN MM): rim, 4.6 mm

INTERIOR SURFACE TREATMENT: smoothed

EXTERIOR SURFACE TREATMENT:

smoothed on the body

HEIGHT (IN CM): 14.0

ORIFICE DIAMETER (IN CM): 14.0

DIAMETER AT BOTTOM OF RIM OR NECK

(IN CM): 11.4

BASE DIAMETER (IN CM) AND SHAPE OF

BASE: 6.4; circular and flat

ESTIMATED VOLUME (IN LITERS): 1.2

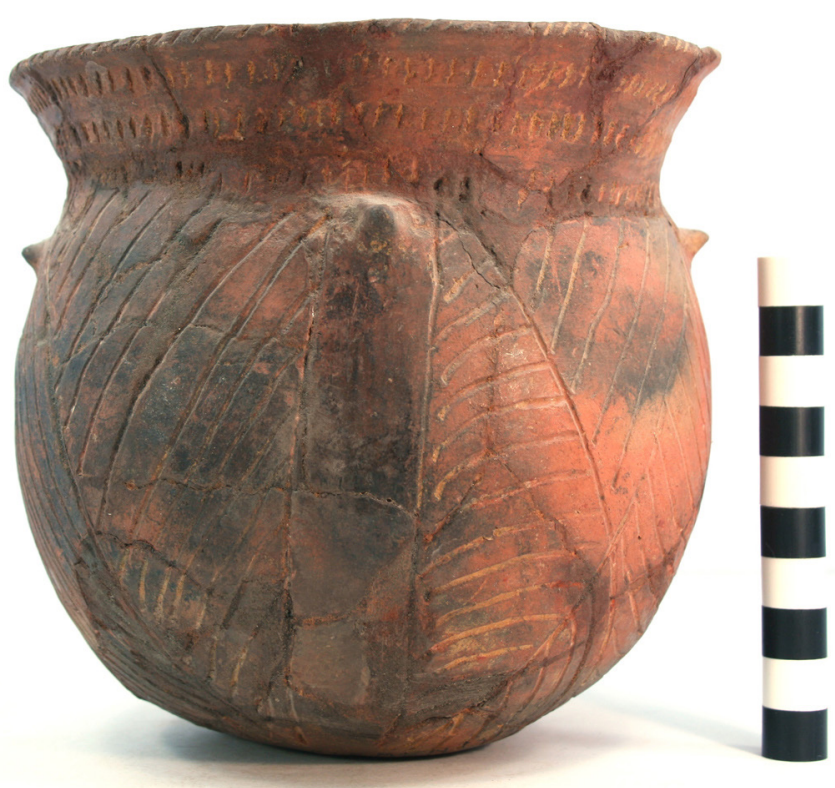

Figure 114. cf. Emory Punctated-Incised jar (Vessel No. 96) from Burial H-14 at the Clements site.

DECORATION (INCLUDING MOTIF AND ELEMENTS WHEN APPARENT): The rim has three rows of tool punctations (Figure 114). The vessel body has four vertical panels filled with diagonal opposed incised triangles. Between each of these panels are narrow vertical panels that have only a single appliqued node at the top of each panel (Figure 114).

PIGMENT USE AND LOCATION ON VESSEL: none

TYPE AND VARIETY (IF KNOWN): cf. Emory Punctated-Incised 
SITE NAME OR SITE NUMBER: Clements

VESSEL NO.: 97, Burial H-14

VESSEL FORM: Olla

NON-PLASTICS AND PASTE: grog and bone

RIM AND LIP FORM: Missing

CORE COLOR: $\mathrm{G}$ (fired in a reducing environment and cooled in the open air)

INTERIOR SURFACE COLOR: grayish-brown

EXTERIOR SURFACE COLOR: yellowish-brown;

fire clouds on the body and base

WALL THICKNESS (IN MM): rim, $8.1 \mathrm{~mm}$; body, $7.5 \mathrm{~mm}$

INTERIOR SURFACE TREATMENT: none

EXTERIOR SURFACE TREATMENT: none

HEIGHT (IN CM): 25.9+ (vessel body)

ORIFICE DIAMETER (IN CM): N/A

DIAMETER AT BOTTOM OF RIM OR NECK (IN CM): N/A

BASE DIAMETER (IN CM) AND SHAPE OF BASE: 7.6; circular and rounded

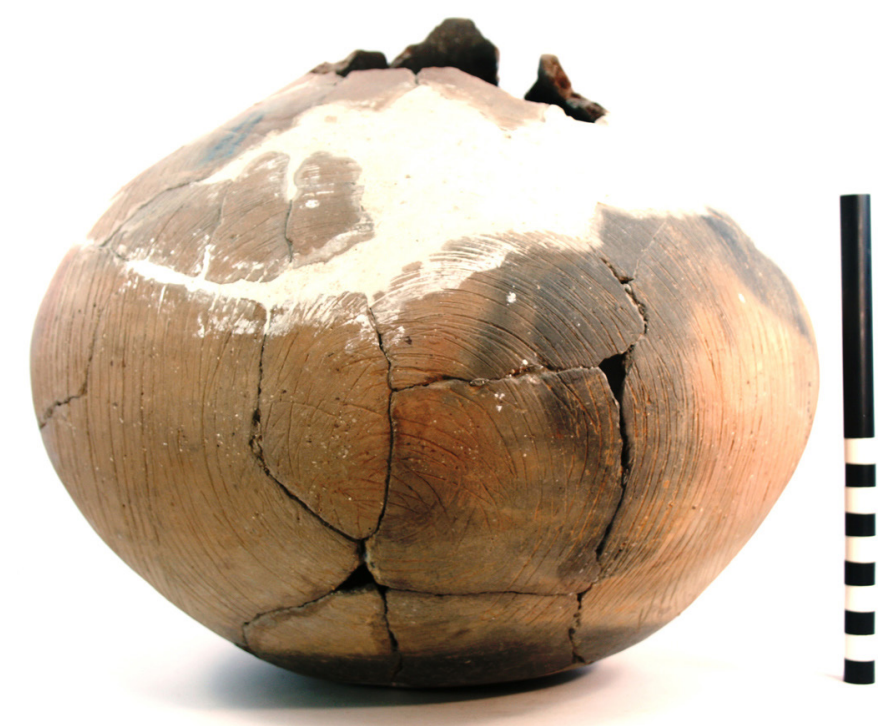

Figure 115. Clements Brushed olla (Vessel No. 97) in Burial H-14 at the Clements site.

ESTIMATED VOLUME (IN LITERS): $1.6+$

DECORATION (INCLUDING MOTIF AND ELEMENTS WHEN APPARENT): The vessel is decorated on the body with curvilinear opposed brushing marks (Figure 115).

PIGMENT USE AND LOCATION ON VESSEL: none

TYPE AND VARIETY (IF KNOWN): Clements Brushed 
SITE NAME OR SITE NUMBER: Clements

VESSEL NO.: 101, Burial H-15

VESSEL FORM: Jar

NON-PLASTICS AND PASTE: grog

RIM AND LIP FORM: Everted rim and rounded lip; lip notched

CORE COLOR: $\mathrm{G}$ (fired in a reducing environment and cooled in the open air)

INTERIOR SURFACE COLOR: very dark gray; fire clouds on the body

EXTERIOR SURFACE COLOR: dark yellowishbrown; fire clouds on the body and base

WALL THICKNESS (IN MM): rim, $7.8 \mathrm{~mm}$; body, $9.2 \mathrm{~mm}$; base, $10.2 \mathrm{~mm}$

INTERIOR SURFACE TREATMENT: smoothed

EXTERIOR SURFACE TREATMENT: none

HEIGHT (IN CM): 29.0

ORIFICE DIAMETER (IN CM): 29.1

DIAMETER AT BOTTOM OF RIM OR NECK (IN CM): 26.6

BASE DIAMETER (IN CM) AND SHAPE OF BASE: 8.2; circular and flat ESTIMATED VOLUME (IN LITERS): 11.0

Figure 116. cf. Mockingbird Punctated jar (Vessel No.

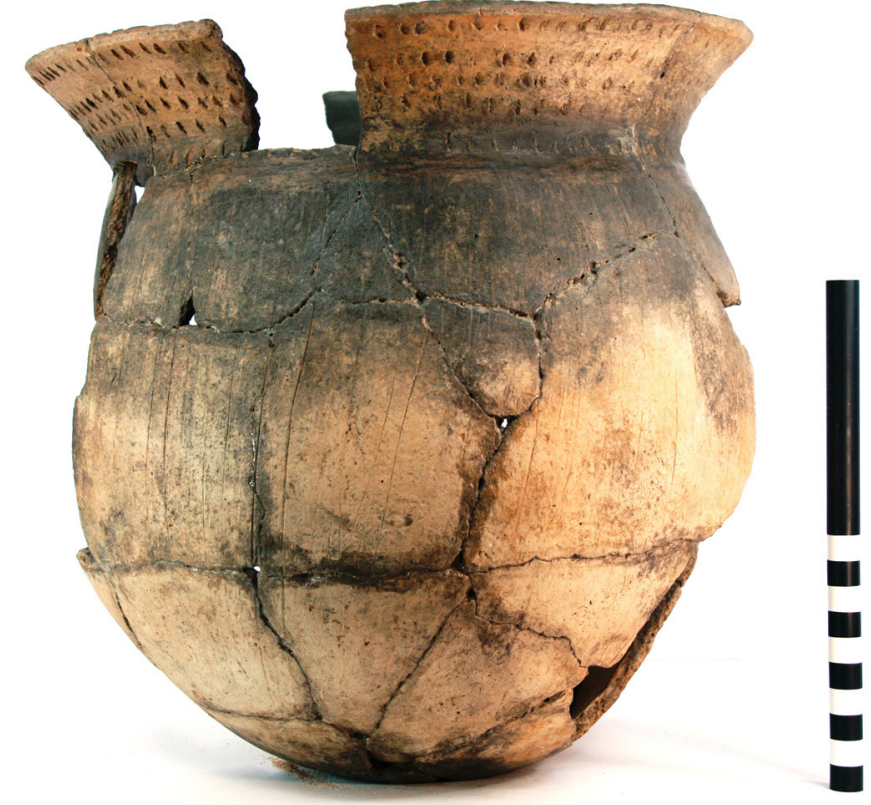
101) in Burial H-15 at the Clements site.

DECORATION (INCLUDING MOTIF AND ELEMENTS WHEN APPARENT): There are four rows of tool punctations on the rim (Figure 116). The vessel body has vertical brushing marks that extend from the rim-body juncture to within $5.0 \mathrm{~cm}$ of the vessel base.

PIGMENT USE AND LOCATION ON VESSEL: none

TYPE AND VARIETY (IF KNOWN): cf. Mockingbird Punctated 
SITE NAME OR SITE NUMBER: Clements

VESSEL NO.: 102, Burial H-15

VESSEL FORM: Deep bowl

NON-PLASTICS AND PASTE: bone

RIM AND LIP FORM: Everted rim and rounded lip

CORE COLOR: $\mathrm{F}$ (fired in a reducing environment and cooled in the open air)

INTERIOR SURFACE COLOR: red

EXTERIOR SURFACE COLOR: red

WALL THICKNESS (IN MM): rim, $5.4 \mathrm{~mm}$

INTERIOR SURFACE TREATMENT: smoothed

EXTERIOR SURFACE TREATMENT: burnished

HEIGHT (IN CM): 10.8

ORIFICE DIAMETER (IN CM): 14.0

DIAMETER AT BOTTOM OF RIM OR

NECK (IN CM): N/A

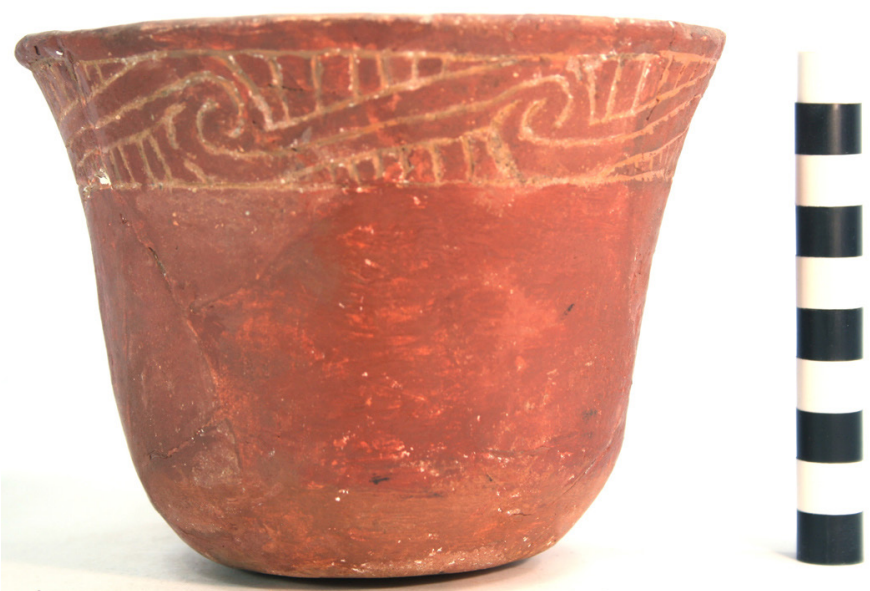

Figure 117. Taylor Engraved deep bowl (Vessel No. 102) in Burial H-15 at the Clements site.

BASE DIAMETER (IN CM) AND SHAPE OF BASE: 6.4; circular and flat

ESTIMATED VOLUME (IN LITERS): 1.2

DECORATION (INCLUDING MOTIF AND ELEMENTS WHEN APPARENT): The interior and exterior surfaces of this vessel have a red slip. The rim of the vessel has an engraved motif repeated seven times around the vessel (Figure 117): the motif is a meandering scroll that ends in a hooked arm element. The upper and lower scroll fill zones are triangular in shape and filled with vertical hatched lines (Figure 117).

PIGMENT USE AND LOCATION ON VESSEL: none

TYPE AND VARIETY (IF KNOWN): Taylor Engraved 
SITE NAME OR SITE NUMBER: Clements

VESSEL NO.: 104, Burial H-15

VESSEL FORM: Carinated bowl

NON-PLASTICS AND PASTE: grog

RIM AND LIP FORM: Inverted-direct rim and rounded lip; lip notched

CORE COLOR: B (fired and cooled in a reducing environment)

INTERIOR SURFACE COLOR: very dark grayish-brown

EXTERIOR SURFACE COLOR: very dark grayish-brown; fire clouds on the rim and body

WALL THICKNESS (IN MM): rim, $3.9 \mathrm{~mm}$; body, $6.2 \mathrm{~mm}$; base, $7.3 \mathrm{~mm}$

INTERIOR SURFACE TREATMENT: burnished

EXTERIOR SURFACE TREATMENT: burnished

HEIGHT (IN CM): 9.6

ORIFICE DIAMETER (IN CM): 18.6

DIAMETER AT BOTTOM OF RIM OR NECK

(IN CM): 20.4

BASE DIAMETER (IN CM) AND SHAPE OF

BASE: 7.6; circular and rounded

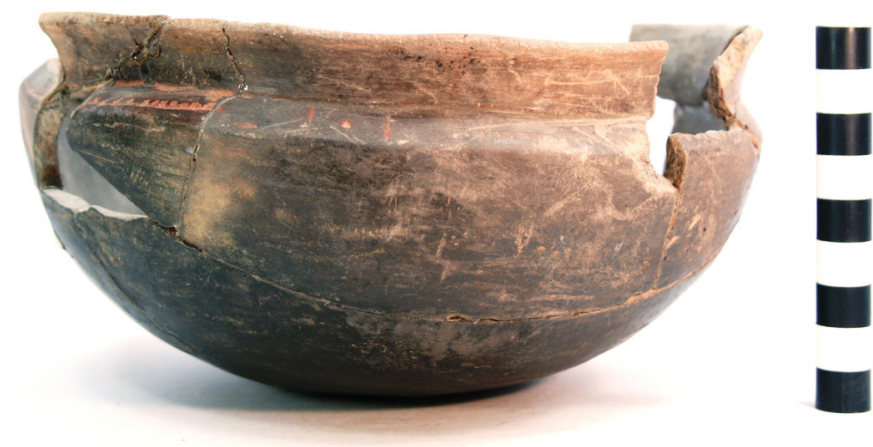

Figure 118. Simms Engraved, var. Darco carinated bowl (Vessel No. 104) in Burial H-15 at the Clements site.

ESTIMATED VOLUME (IN LITERS): 1.1

DECORATION (INCLUDING MOTIF AND ELEMENTS WHEN APPARENT): The rim is divided into four horizontal panels with a single diagonal engraved line and upward-pointing excised tick marks (Figure 118). Between the panels are four vertical engraved panels that each have a single central excised circular punctation.

PIGMENT USE AND LOCATION ON VESSEL: red pigment in the engraved lines

TYPE AND VARIETY (IF KNOWN): Simms Engraved, var. Darco 
SITE NAME OR SITE NUMBER: Clements

VESSEL NO.: 105a, Burial H-15

VESSEL FORM: Olla

NON-PLASTICS AND PASTE: grog and bone

RIM AND LIP FORM: Direct rim and rounded, exterior folded lip

CORE COLOR: $\mathrm{F}$ (fired in a reducing environment and cooled in the open air)

INTERIOR SURFACE COLOR: yellowish-brown; fire clouds on the body and base

EXTERIOR SURFACE COLOR: yellowish-

brown; fire clouds on the rim, body, and the base

WALL THICKNESS (IN MM): rim, $5.7 \mathrm{~mm}$;

body, $6.9 \mathrm{~mm}$

INTERIOR SURFACE TREATMENT: none

EXTERIOR SURFACE TREATMENT: none

HEIGHT (IN CM): 24.3

ORIFICE DIAMETER (IN CM): 8.9

DIAMETER AT BOTTOM OF RIM OR NECK

(IN CM): 8.5

BASE DIAMETER (IN CM) AND SHAPE OF

BASE: 7.6; circular and flat

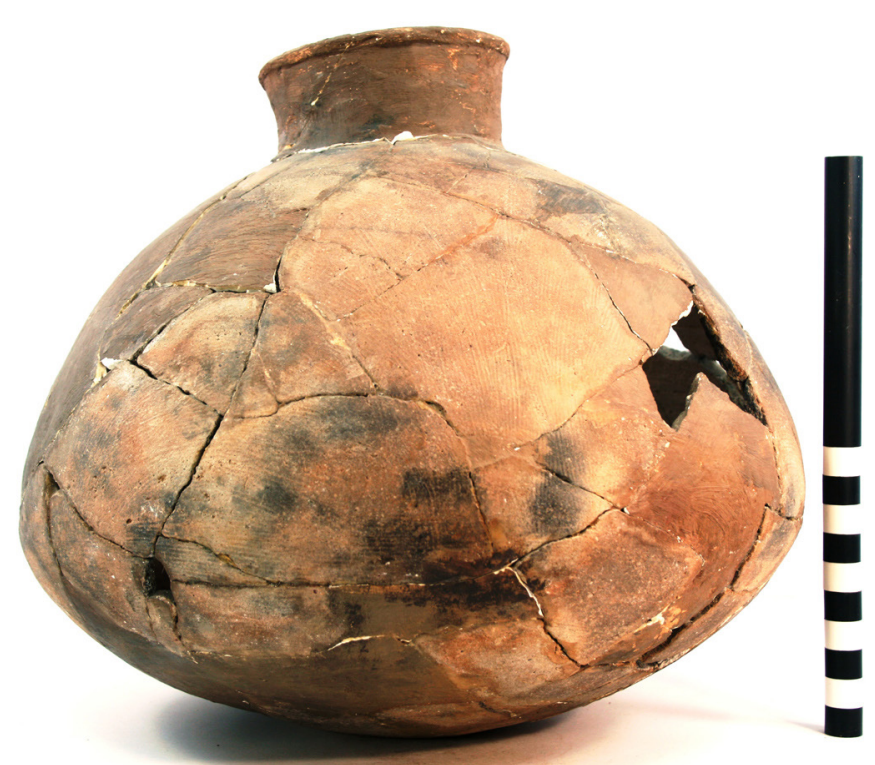

Figure 119. Clements Brushed olla (Vessel No. 105a) in Burial $\mathrm{H}-15$ at the Clements site.

\section{ESTIMATED VOLUME (IN LITERS): 1.5}

DECORATION (INCLUDING MOTIF AND ELEMENTS WHEN APPARENT): The rim of the vessel is plain, and the vessel body has opposed brushing marks (Figure 119).

PIGMENT USE AND LOCATION ON VESSEL: none

TYPE AND VARIETY (IF KNOWN): Clements Brushed 
SITE NAME OR SITE NUMBER: Clements

VESSEL NO.: 105b, Burial H-15

VESSEL FORM: Olla

NON-PLASTICS AND PASTE: grog

RIM AND LIP FORM: Everted rim and rounded lip

CORE COLOR: $\mathrm{G}$ (fired in a reducing environment and cooled in the open air)

INTERIOR SURFACE COLOR: grayish-brown

EXTERIOR SURFACE COLOR: yellowish-brown; fire clouds on the rim, body, and base

WALL THICKNESS (IN MM): rim, $8.0 \mathrm{~mm}$

INTERIOR SURFACE TREATMENT: none

EXTERIOR SURFACE TREATMENT: none

HEIGHT (IN CM): 28.0

ORIFICE DIAMETER (IN CM): 10.2

DIAMETER AT BOTTOM OF RIM OR NECK (IN CM): 8.9

BASE DIAMETER (IN CM) AND SHAPE OF BASE: 8.2; circular and flat

ESTIMATED VOLUME (IN LITERS): 1.8

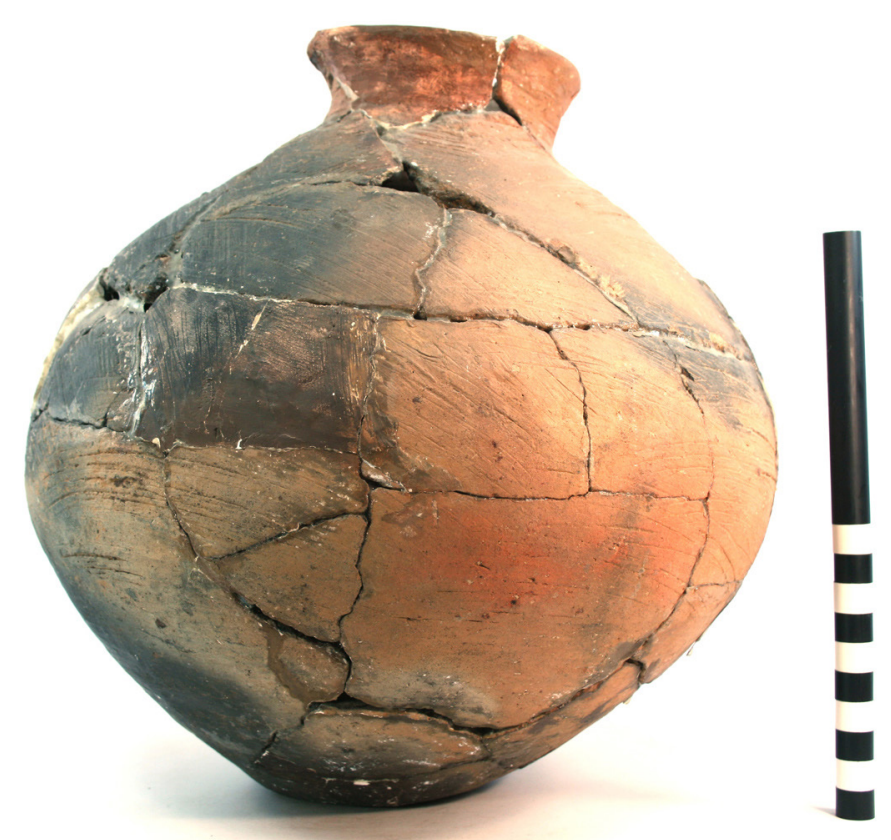

Figure 120. Clements Brushed olla (Vessel No. 105b) in Burial H-15 at the Clements site.

DECORATION (INCLUDING MOTIF AND ELEMENTS WHEN APPARENT): There are horizontal brushing marks on the rim, and overlapping brushing marks on the upper half of the vessel body (Figure 120).

PIGMENT USE AND LOCATION ON VESSEL: none

TYPE AND VARIETY (IF KNOWN): Clements Brushed 
SITE NAME OR SITE NUMBER: Clements

VESSEL NO.: 177, Burial H-18

VESSEL FORM: Jar

NON-PLASTICS AND PASTE: bone

RIM AND LIP FORM: Everted rim and rounded, exterior folded lip

CORE COLOR: $\mathrm{F}$ (fired in a reducing environment and cooled in the open air)

INTERIOR SURFACE COLOR: dark reddish-brown; fire clouds on the rim, body, and base

EXTERIOR SURFACE COLOR: reddish-brown; fire clouds on the rim, body, and base

WALL THICKNESS (IN MM): rim, $10.0 \mathrm{~mm}$; body, $8.9 \mathrm{~mm}$; base, $9.6 \mathrm{~mm}$

INTERIOR SURFACE TREATMENT: smoothed

EXTERIOR SURFACE TREATMENT: smoothed on the upper body

HEIGHT (IN CM): 27.2

ORIFICE DIAMETER (IN CM): 27.3

DIAMETER AT BOTTOM OF RIM OR NECK (IN CM): 26.1

BASE DIAMETER (IN CM) AND SHAPE OF BASE: 10.7; circular and flat

ESTIMATED VOLUME (IN LITERS): 9.7

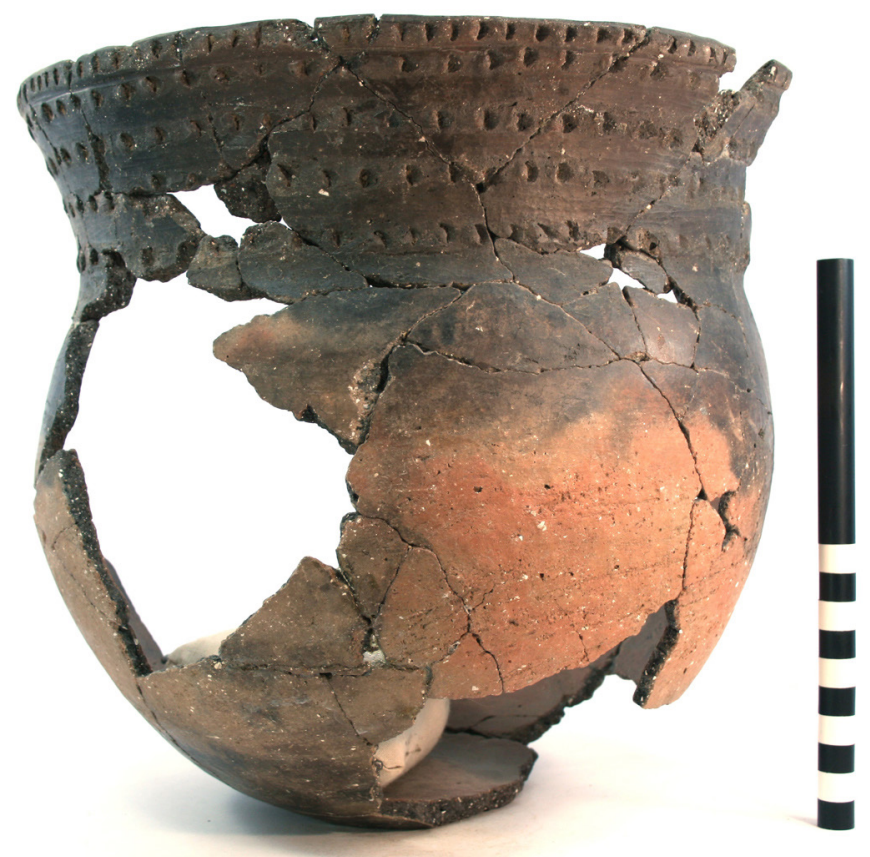

Figure 121. Mockingbird Punctated jar (Vessel No. 177) in Burial $\mathrm{H}-18$ at the Clements site.

DECORATION (INCLUDING MOTIF AND ELEMENTS WHEN APPARENT): There are four horizontal rows of tool punctations on the vessel rim (Figure 121). The folded over lip also has a row of tool punctations.

PIGMENT USE AND LOCATION ON VESSEL: none

TYPE AND VARIETY (IF KNOWN): Mockingbird Punctated 
SITE NAME OR SITE NUMBER: Clements

VESSEL NO.: 191, Burial H-19

VESSEL FORM: Carinated bowl

NON-PLASTICS AND PASTE: grog

RIM AND LIP FORM: Inverted-direct rim and rounded lip

CORE COLOR: F (fired in a reducing environment and cooled in the open air)

INTERIOR SURFACE COLOR: black

EXTERIOR SURFACE COLOR: black

WALL THICKNESS (IN MM): rim, 7.4 mm; body, $6.6 \mathrm{~mm}$; base, $10.3 \mathrm{~mm}$

INTERIOR SURFACE TREATMENT: burnished

EXTERIOR SURFACE TREATMENT: burnished

HEIGHT (IN CM): 16.8

ORIFICE DIAMETER (IN CM): 17.8

DIAMETER AT BOTTOM OF RIM OR NECK (IN CM): 18.6

BASE DIAMETER (IN CM) AND SHAPE OF BASE: 6.6; circular and flat

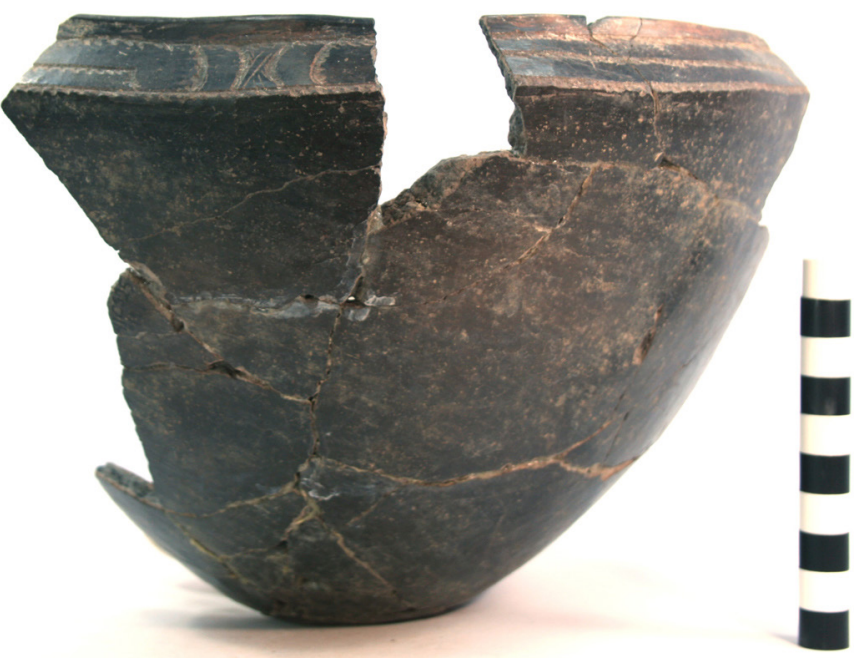

Figure 122. Simms Engraved carinated bowl (Vessel No. 191) in Burial H-19 at the Clements site.

\section{ESTIMATED VOLUME (IN LITERS): 2.7}

DECORATION (INCLUDING MOTIF AND ELEMENTS WHEN APPARENT): There is a black slip on interior and exterior vessel surfaces. The rim has four horizontal panels around the vessel that have three horizontal engraved lines with downward-pointing excised tick marks (Figure 122); the middle of the three lines also curves down to meet the bottom horizontal engraved line. The horizontal engraved panels are divided by two opposed curvilinear lines that have tick marks as well as a central engraved bracket filled with hatched lines (Figure 122).

PIGMENT USE AND LOCATION ON VESSEL: white pigment in the engraved lines TYPE AND VARIETY (IF KNOWN): Simms Engraved 
SITE NAME OR SITE NUMBER: Clements

VESSEL NO.: 204a, Burial H-21

VESSEL FORM: Jar

NON-PLASTICS AND PASTE: grog

RIM AND LIP FORM: N/A

CORE COLOR: $\mathrm{G}$ (fired in a reducing environment and cooled in the open air)

INTERIOR SURFACE COLOR: grayish-brown; fire clouds on the body

EXTERIOR SURFACE COLOR: yellowishbrown; fire clouds on the rim, body, and base

WALL THICKNESS (IN MM): rim, $5.3 \mathrm{~mm}$

INTERIOR SURFACE TREATMENT: smoothed

EXTERIOR SURFACE TREATMENT: none

HEIGHT (IN CM): 16.5+

ORIFICE DIAMETER (IN CM): 15.8

DIAMETER AT BOTTOM OF RIM OR NECK (IN CM): 15.8

BASE DIAMETER (IN CM) AND SHAPE OF BASE: 7.6; circular and flat

ESTIMATED VOLUME (IN LITERS): 2.3+

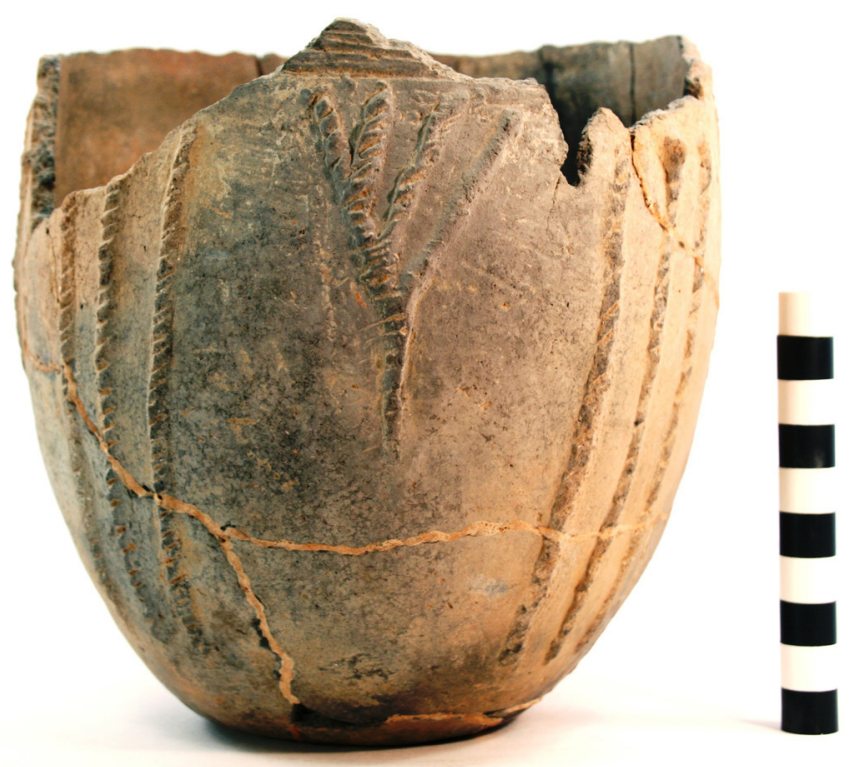

Figure 123. Incised-appliqued jar (Vessel No. 204a) from Burial H-21 at the Clements site.

DECORATION (INCLUDING MOTIF AND ELEMENTS WHEN APPARENT): The rim of the vessel is decorated with closely-spaced horizontal incised lines (Figure 123). The vessel body has four sets of appliqued fillet triangle elements between four sets of three closely-spaced vertical appliqued fillets that extend close to the vessel base (Figure 123).

PIGMENT USE AND LOCATION ON VESSEL: none

TYPE AND VARIETY (IF KNOWN): Unidentified utility ware, cf. Harleton Appliqued 
SITE NAME OR SITE NUMBER: Clements

VESSEL NO.: 204b, Burial H-21

VESSEL FORM: Jar; undecorated body section only

NON-PLASTICS AND PASTE: grog

RIM AND LIP FORM: N/A

CORE COLOR: A (fired and cooled in an oxidizing environment)

INTERIOR SURFACE COLOR: dark reddish-brown; fire clouds and organic residue on the body

EXTERIOR SURFACE COLOR: dark reddish-brown

WALL THICKNESS (IN MM): body, $7.7 \mathrm{~mm}$

INTERIOR SURFACE TREATMENT: none

EXTERIOR SURFACE TREATMENT: smoothed

HEIGHT (IN CM): N/A

ORIFICE DIAMETER (IN CM): N/A

DIAMETER AT BOTTOM OF RIM OR NECK (IN CM): N/A

BASE DIAMETER (IN CM) AND SHAPE OF BASE: N/A

ESTIMATED VOLUME (IN LITERS): N/A

DECORATION (INCLUDING MOTIF AND ELEMENTS WHEN APPARENT): Plain

PIGMENT USE AND LOCATION ON VESSEL: none

TYPE AND VARIETY (IF KNOWN): Unidentified ceramic ware 
SITE NAME OR SITE NUMBER: Clements

VESSEL NO.: 215, Burial H-22

VESSEL FORM: Carinated bowl

NON-PLASTICS AND PASTE: grog

RIM AND LIP FORM: Inverted-direct rim and rounded lip; thickened rim

CORE COLOR: $\mathrm{G}$ (fired in a reducing environment and cooled in the open air)

INTERIOR SURFACE COLOR: grayish-brown; fire clouds on the rim and body

EXTERIOR SURFACE COLOR: yellowish-brown; fire clouds on the rim, body, and base

WALL THICKNESS (IN MM): rim, $7.3 \mathrm{~mm}$;

body, $4.3 \mathrm{~mm}$

INTERIOR SURFACE TREATMENT: burnished

EXTERIOR SURFACE TREATMENT: burnished

HEIGHT (IN CM): 8.1

ORIFICE DIAMETER (IN CM): 13.0

DIAMETER AT BOTTOM OF RIM OR NECK

(IN CM): 12.1

BASE DIAMETER (IN CM) AND SHAPE OF

BASE: 6.4; circular and rounded

ESTIMATED VOLUME (IN LITERS): 0.63

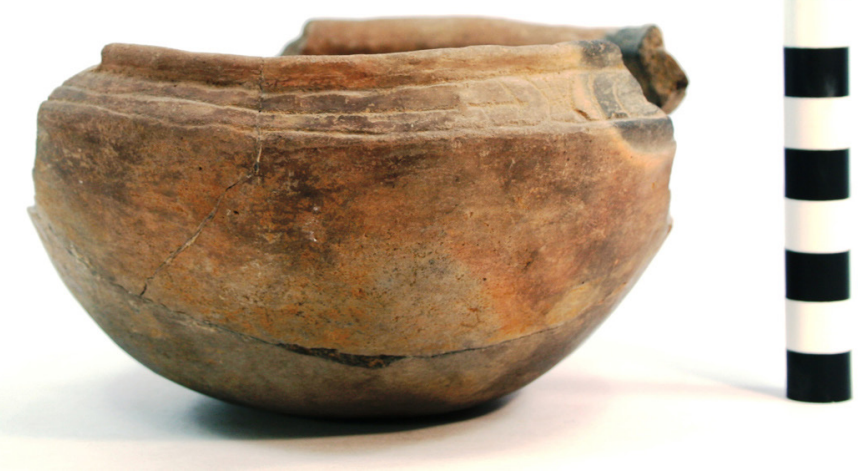

Figure 124. Simms Engraved carinated bowl (Vessel No. 215) in Burial H-22 at the Clements site.

DECORATION (INCLUDING MOTIF AND ELEMENTS WHEN APPARENT): The rim has four horizontal engraved panels with upper and lower horizontal engraved lines and a single central horizontal and vertical engraved line (Figure 124). The ends of each panel are defined by one or two curvilinear engraved lines, and the panels are divided by cross-hatched engraved brackets (Figure 124).

PIGMENT USE AND LOCATION ON VESSEL: none

TYPE AND VARIETY (IF KNOWN): Simms Engraved 
SITE NAME OR SITE NUMBER: Clements

VESSEL NO.: X-1, unknown context

VESSEL FORM: Carinated bowl; body/base section only

NON-PLASTICS AND PASTE: grog

RIM AND LIP FORM: N/A

CORE COLOR: F (fired in a reducing environment and cooled in the open air)

INTERIOR SURFACE COLOR: brown

EXTERIOR SURFACE COLOR: dark brown; fire clouds on the body and base

WALL THICKNESS (IN MM): body, $6.3 \mathrm{~mm}$

INTERIOR SURFACE TREATMENT: none

EXTERIOR SURFACE TREATMENT: burnished

HEIGHT (IN CM): N/A

ORIFICE DIAMETER (IN CM): N/A

DIAMETER AT BOTTOM OF RIM OR NECK

(IN CM): N/A

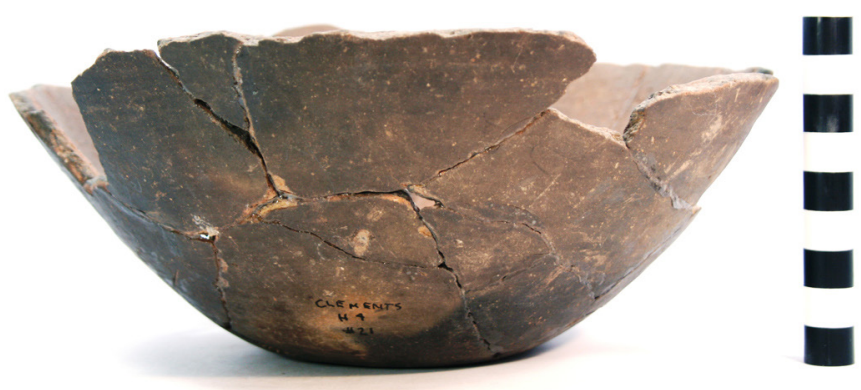

Figure 125. Plain body and base of a carinated bowl (Vessel No. X-1), unknown context at the Clements site.

BASE DIAMETER (IN CM) AND SHAPE OF

BASE: 6.4; circular and flat

ESTIMATED VOLUME (IN LITERS): N/A

DECORATION (INCLUDING MOTIF AND ELEMENTS WHEN APPARENT): Plain body (Figure 125)

PIGMENT USE AND LOCATION ON VESSEL: none

TYPE AND VARIETY (IF KNOWN): Unidentified ware 
SITE NAME OR SITE NUMBER: Clements

VESSEL NO.: X2, unknown context

VESSEL FORM: Carinated bowl

NON-PLASTICS AND PASTE: grog

RIM AND LIP FORM: Inverted-direct rim and rounded lip; lip-notched

CORE COLOR: B (fired and cooled in a reducing environment)

INTERIOR SURFACE COLOR: very dark gray

EXTERIOR SURFACE COLOR: black

WALL THICKNESS (IN MM): rim, $4.8 \mathrm{~mm}$; body, $4.8 \mathrm{~mm}$

INTERIOR SURFACE TREATMENT: smoothed

EXTERIOR SURFACE TREATMENT:

burnished

HEIGHT (IN CM): 7.0

ORIFICE DIAMETER (IN CM): 14.6

DIAMETER AT BOTTOM OF RIM OR NECK

(IN CM): 16.5

BASE DIAMETER (IN CM) AND SHAPE OF BASE: N/A

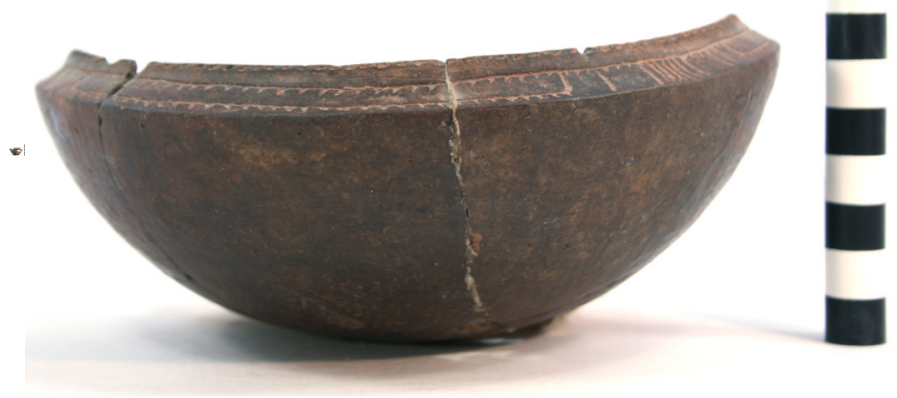

Figure 126. Simms Engraved carinated bowl (Vessel No. X-2) in unknown context at the Clements site.

ESTIMATED VOLUME (IN LITERS): 0.61

DECORATION (INCLUDING MOTIF AND ELEMENTS WHEN APPARENT): The rim is divided into four panels with an upper horizontal engraved line and a central horizontal to vertical engraved line; these lines have downward-pointing excised tick marks (Figure 126). The ends of the panels are marked by single vertical engraved lines. Between the panels are vertical zones filled with vertical hatched lines (Figure 126).

PIGMENT USE AND LOCATION ON VESSEL: none

TYPE AND VARIETY (IF KNOWN): Simms Engraved 
SITE NAME OR SITE NUMBER: Clements

VESSEL NO.: X-3, unknown context

VESSEL FORM: Carinated bowl

NON-PLASTICS AND PASTE: grog

RIM AND LIP FORM: Inverted-direct rim and rounded lip

CORE COLOR: F (fired in a reducing environment and cooled in the open air)

INTERIOR SURFACE COLOR: very dark grayish-brown; fire clouds on the rim

EXTERIOR SURFACE COLOR: very dark grayish-brown; fire clouds on the rim

WALL THICKNESS (IN MM): rim, 3.9 mm; body,

$4.2 \mathrm{~mm}$

INTERIOR SURFACE TREATMENT: burnished

EXTERIOR SURFACE TREATMENT: burnished

HEIGHT (IN CM): 7.5

ORIFICE DIAMETER (IN CM): 11.5

DIAMETER AT BOTTOM OF RIM OR NECK (IN

CM): 12.2

BASE DIAMETER (IN CM) AND SHAPE OF

BASE: 3.3 ; circular and concave

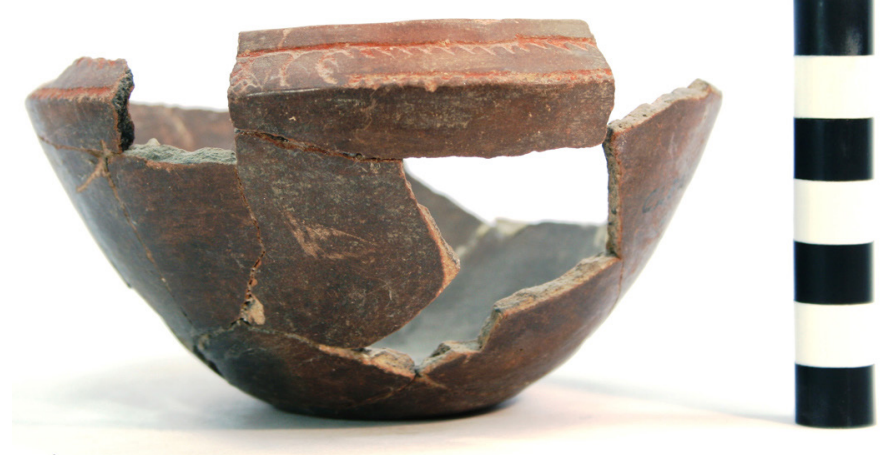

Figure 127. Simms Engraved carinated bowl (Vessel No. $\mathrm{X}-3$ ) in unknown context at the Clements site.

ESTIMATED VOLUME (IN LITERS): 0.52

DECORATION (INCLUDING MOTIF AND ELEMENTS WHEN APPARENT): The vessel has a very dark grayish-brown slip on interior and exterior vessel surfaces. The rim has four horizontal panels with two curvilinear engraved lines at each end of the panel (Figure 127). The panels have two horizontal engraved lines with downward-pointing excised tick marks. Between each of the panels are engraved brackets filled with cross-hatched engraved lines (Figure 127).

PIGMENT USE AND LOCATION ON VESSEL: red pigment in the engraved lines

TYPE AND VARIETY (IF KNOWN): Simms Engraved 
SITE NAME OR SITE NUMBER: Clements

VESSEL NO.: X-4, unknown context

VESSEL FORM: Carinated bowl

NON-PLASTICS AND PASTE: grog

RIM AND LIP FORM: N/A

CORE COLOR: F (fired in a reducing environment and cooled in the open air)

INTERIOR SURFACE COLOR: yellowish-brown; fire clouds on the rim, body, and base

EXTERIOR SURFACE COLOR: dark yellowishbrown; fire clouds on the body and base

WALL THICKNESS (IN MM): rim, $6.7 \mathrm{~mm}$; body; $6.8 \mathrm{~mm}$

INTERIOR SURFACE TREATMENT: smoothed

EXTERIOR SURFACE TREATMENT: burnished

HEIGHT (IN CM): 14.6+

ORIFICE DIAMETER (IN CM): 27.2

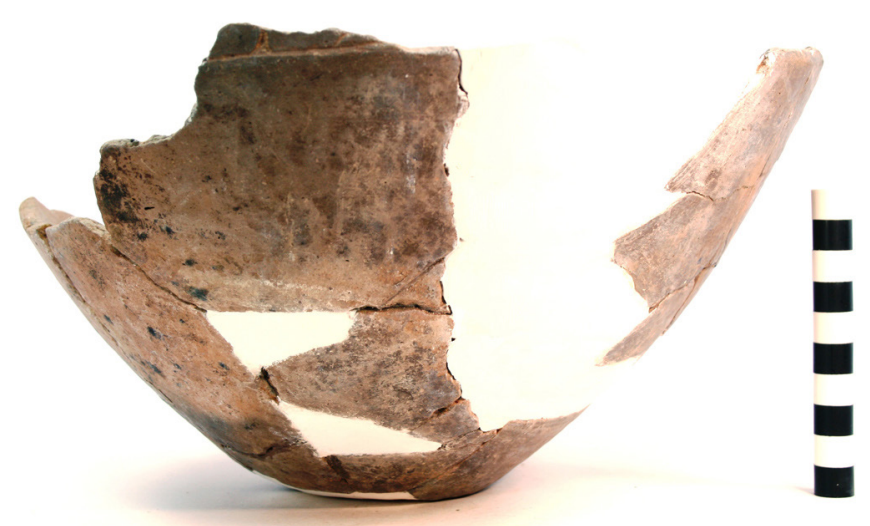

Figure 128. Engraved carinated bowl (Vessel No. X-4) in unknown context at the Clements site.

DIAMETER AT BOTTOM OF RIM OR NECK

(IN CM): 27.2

BASE DIAMETER (IN CM) AND SHAPE OF BASE: 6.4; circular and concave

ESTIMATED VOLUME (IN LITERS): 3.6+

DECORATION (INCLUDING MOTIF AND ELEMENTS WHEN APPARENT): The vast majority of the rim is missing on this vessel, and the engraved elements visible include a single horizontal line above the carination, a single diagonal engraved line, and a narrow excised vertical column, possibly part of an excised bracket (Figure 128).

PIGMENT USE AND LOCATION ON VESSEL: none

TYPE AND VARIETY (IF KNOWN): Unidentified fine ware 
SITE NAME OR SITE NUMBER: Clements

VESSEL NO.: X-5, unknown context

VESSEL FORM: Bottle with a spool neck and a carinated body

NON-PLASTICS AND PASTE: grog

RIM AND LIP FORM: N/A

CORE COLOR: $\mathrm{G}$ (fired in a reducing environment and cooled in the open air)

INTERIOR SURFACE COLOR: dark gray

EXTERIOR SURFACE COLOR: yellowish-brown; fire clouds on the rim, body, and base

WALL THICKNESS (IN MM): rim, $6.2 \mathrm{~mm}$;

body, $5.4 \mathrm{~mm}$

INTERIOR SURFACE TREATMENT: none

EXTERIOR SURFACE TREATMENT: burnished

HEIGHT (IN CM): 16.5+

ORIFICE DIAMETER (IN CM): N/A

DIAMETER AT BOTTOM OF RIM OR NECK

(IN CM): N/A

BASE DIAMETER (IN CM) AND SHAPE OF

BASE: 5.8; circular and concave

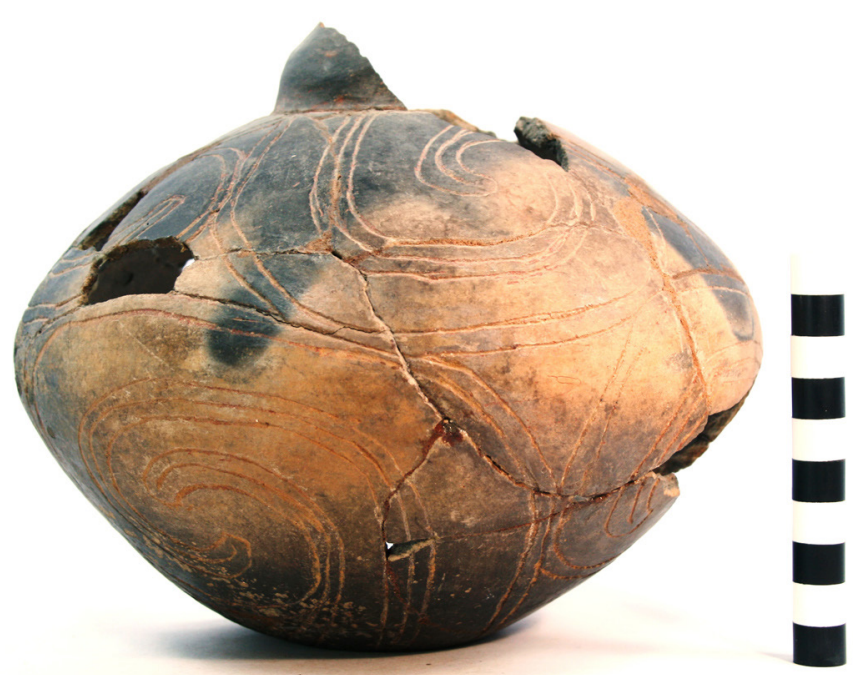

Figure 129. Engraved bottle (Vessel No. $X-5)$ in unknown context at the Clements site.

ESTIMATED VOLUME (IN LITERS): 0.38+

DECORATION (INCLUDING MOTIF AND ELEMENTS WHEN APPARENT): The vessel body has four sets of three upper (on the upper body) and lower (on the lower body) engraved spiral whorls that end in hooked arm elements (Figure 129). A very similar decorated bottle is in the W. T. Scott collections from the Clements site (Perttula et al. 2010:Figure 16b).

PIGMENT USE AND LOCATION ON VESSEL: red pigment in engraved lines

TYPE AND VARIETY (IF KNOWN): Unidentified fine ware, cf. Keno Trailed, var. Glendora or Fatherland Incised, var. Pine Ridge (Brain 1988; Brown 1998:54) 
SITE NAME OR SITE NUMBER: Clements

VESSEL NO.: X-6, unknown context

VESSEL FORM: Jar

NON-PLASTICS AND PASTE: grog

RIM AND LIP FORM: Everted rim and rounded lip; lip notched

CORE COLOR: $\mathrm{G}$ (fired in a reducing environment and cooled in the open air)

INTERIOR SURFACE COLOR: dark gray

EXTERIOR SURFACE COLOR: dark reddishbrown

WALL THICKNESS (IN MM): rim, $4.5 \mathrm{~mm}$

INTERIOR SURFACE TREATMENT: smoothed

EXTERIOR SURFACE TREATMENT: none

HEIGHT (IN CM): 11.5

ORIFICE DIAMETER (IN CM): 12.7

DIAMETER AT BOTTOM OF RIM OR NECK (IN CM): 10.7

BASE DIAMETER (IN CM) AND SHAPE OF BASE: 4.3 ; circular and flat

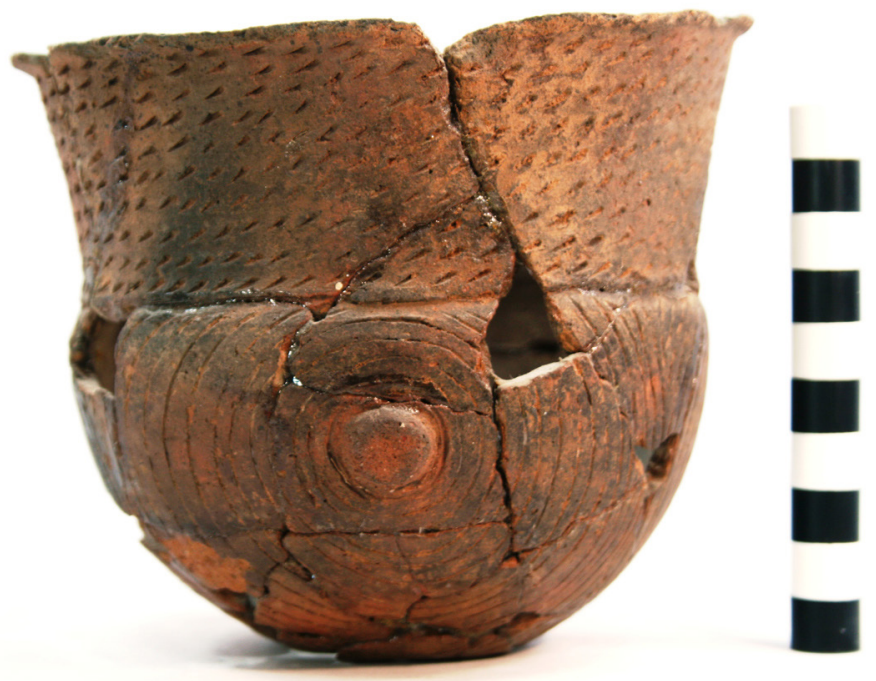

Figure 130. Foster Trailed-Incised, var. unspecified jar (Vessel No. X-6) in an unknown context at the Clements site.

ESTIMATED VOLUME (IN LITERS): 0.87

DECORATION (INCLUDING MOTIF AND ELEMENTS WHEN APPARENT): The rim of the vessel is decorated with 10 horizontal rows of diagonal tool punctations (Figure 130). The vessel body has three sets of concentric incised circles around large (14.6 mm in diameter) and flattened appliqued nodes (Figure 130).

PIGMENT USE AND LOCATION ON VESSEL: none

TYPE AND VARIETY (IF KNOWN): Foster Trailed-Incised, var. unspecified 
SITE NAME OR SITE NUMBER: Clements

VESSEL NO.: X-7, unknown context

VESSEL FORM: Jar with a short rim

NON-PLASTICS AND PASTE: grog

RIM AND LIP FORM: Everted and thickened rim and rounded lip

CORE COLOR: $\mathrm{G}$ (fired in a reducing environment and cooled in the open air)

INTERIOR SURFACE COLOR: dark gray; fire clouds on the body

EXTERIOR SURFACE COLOR: yellowish-brown; fire clouds on the rim and body

WALL THICKNESS (IN MM): rim, $8.0 \mathrm{~mm}$; body, $5.0 \mathrm{~mm}$

INTERIOR SURFACE TREATMENT: smoothed

EXTERIOR SURFACE TREATMENT: none

HEIGHT (IN CM): 28.0+

ORIFICE DIAMETER (IN CM): 15.2

DIAMETER AT BOTTOM OF RIM OR NECK (IN CM): 12.7

BASE DIAMETER (IN CM) AND SHAPE OF BASE: N/A

ESTIMATED VOLUME (IN LITERS): 5.5

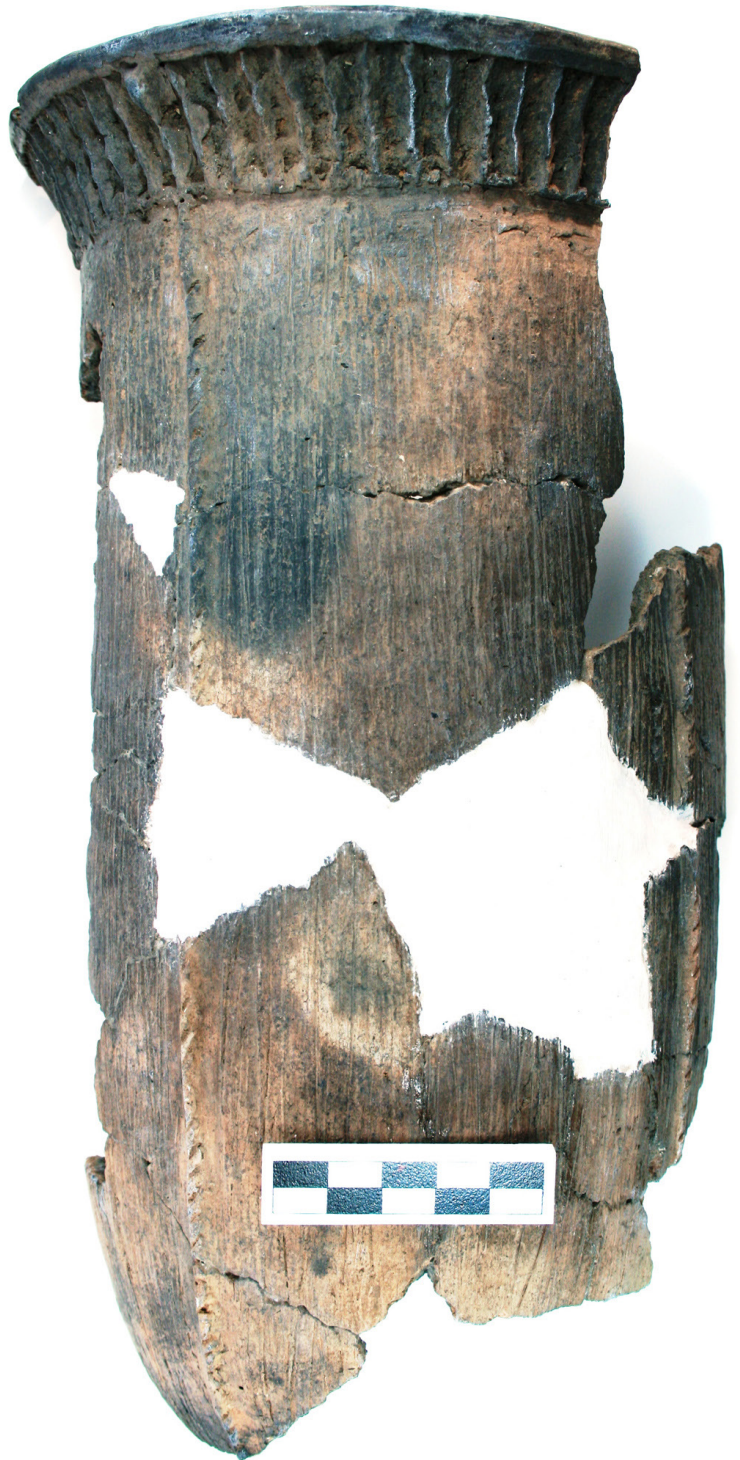

Figure 131. Pinched-brushed jar (Vessel No. X-7) in unknown context at the Clements site.

DECORATION (INCLUDING MOTIF AND ELEMENTS WHEN APPARENT): The rim is decorated with a continuous series of vertical pinched ridges (Figure 131). The vessel body is divided into four panels by vertical appliqued fillets, and the panels are filled with vertical brushing marks.

PIGMENT USE AND LOCATION ON VESSEL: none

TYPE AND VARIETY (IF KNOWN): Unidentified utility ware 
SITE NAME OR SITE NUMBER: Clements

VESSEL NO.: X-8, unknown context

VESSEL FORM: Compound bowl

NON-PLASTICS AND PASTE: grog

RIM AND LIP FORM: Everted rim and rounded lip

CORE COLOR: F (fired in a reducing environment and cooled in the open air)

INTERIOR SURFACE COLOR: yellowish-brown; fire clouds on the rim, body, and base

EXTERIOR SURFACE COLOR: yellowishbrown; fire clouds on the rim, body, and base

WALL THICKNESS (IN MM): rim, $6.2 \mathrm{~mm}$

INTERIOR SURFACE TREATMENT: smoothed

EXTERIOR SURFACE TREATMENT: burnished on lower rim panel

HEIGHT (IN CM): 29.0

ORIFICE DIAMETER (IN CM): 30.9

DIAMETER AT BOTTOM OF RIM OR NECK

(IN CM): 30.0 (upper panel), 31.6 (lower panel)

BASE DIAMETER (IN CM) AND SHAPE OF

BASE: 8.9; circular and flat

\section{ESTIMATED VOLUME (IN LITERS): 7.2}

Figure 132. Engraved compound bowl (Vessel No.

$\mathrm{X}-8$ ) in unknown context from the Clements site.

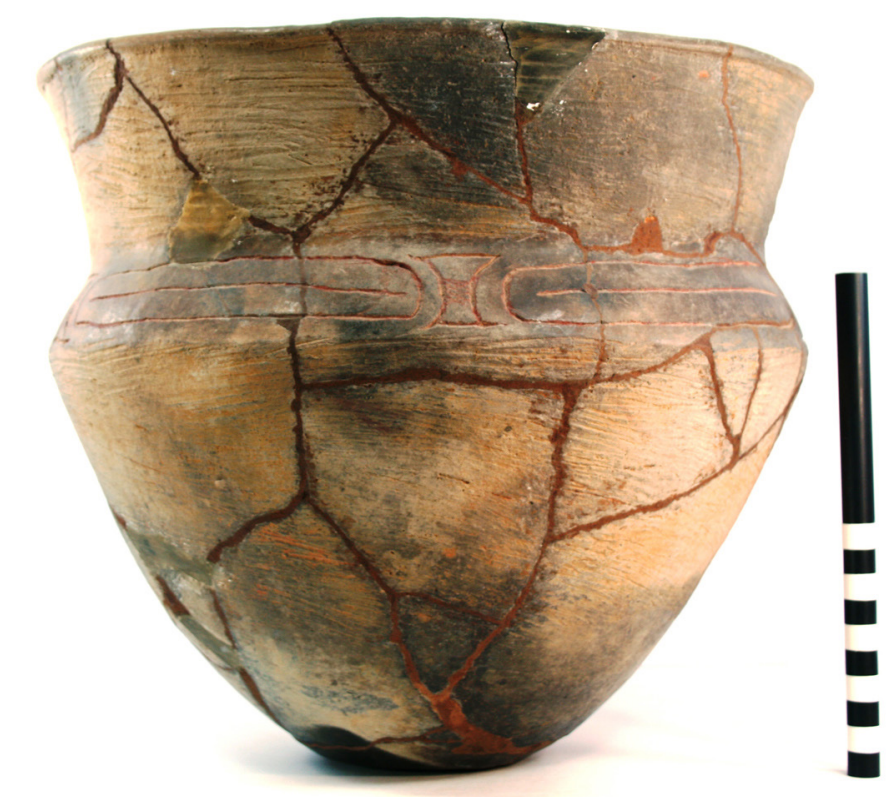

DECORATION (INCLUDING MOTIF AND ELEMENTS WHEN APPARENT): The upper rim panel and the vessel body (to within $9.0 \mathrm{~cm}$ of the vessel base) have horizontal brushing marks (Figure 132). The lower rim panel has five horizontal and curvilinear zones filled with a single horizontal engraved line. These zones are divided by engraved brackets with a central excised area (Figure 132).

PIGMENT USE AND LOCATION ON VESSEL: red pigment in engraved lines on lower rim panel

TYPE AND VARIETY (IF KNOWN): Unidentified fine ware, probably Simms Engraved. Suhm and Jelks (1962:Plate 14a) include the vessel in the Clements Brushed type because of the horizontal brushing on the rim and vessel body, but it is clearly stylistically and incongruous with other Clements Brushed ollas illustrated by Suhm and Jelks (1962:Plate 14b-d'). 
SITE NAME OR SITE NUMBER: Clements

VESSEL NO.: X-9, unknown context

VESSEL FORM: Compound bowl

NON-PLASTICS AND PASTE: bone

RIM AND LIP FORM: Everted rim and rounded lip

CORE COLOR: F (fired in a reducing environment and cooled in the open air)

INTERIOR SURFACE COLOR: yellowish-brown; fire clouds on the rim and base

EXTERIOR SURFACE COLOR: yellowish-

brown; fire clouds on the rim, body, and base

WALL THICKNESS (IN MM): rim, 8.4 mm

INTERIOR SURFACE TREATMENT: smoothed

EXTERIOR SURFACE TREATMENT: smoothed

HEIGHT (IN CM): 24.7

ORIFICE DIAMETER (IN CM): 25.5

DIAMETER AT BOTTOM OF RIM OR NECK

(IN CM): 24.0

BASE DIAMETER (IN CM) AND SHAPE OF

BASE: 7.0; circular and flat

ESTIMATED VOLUME (IN LITERS): 5.0

Figure 133. Engraved fine ware compound bowl (Vessel

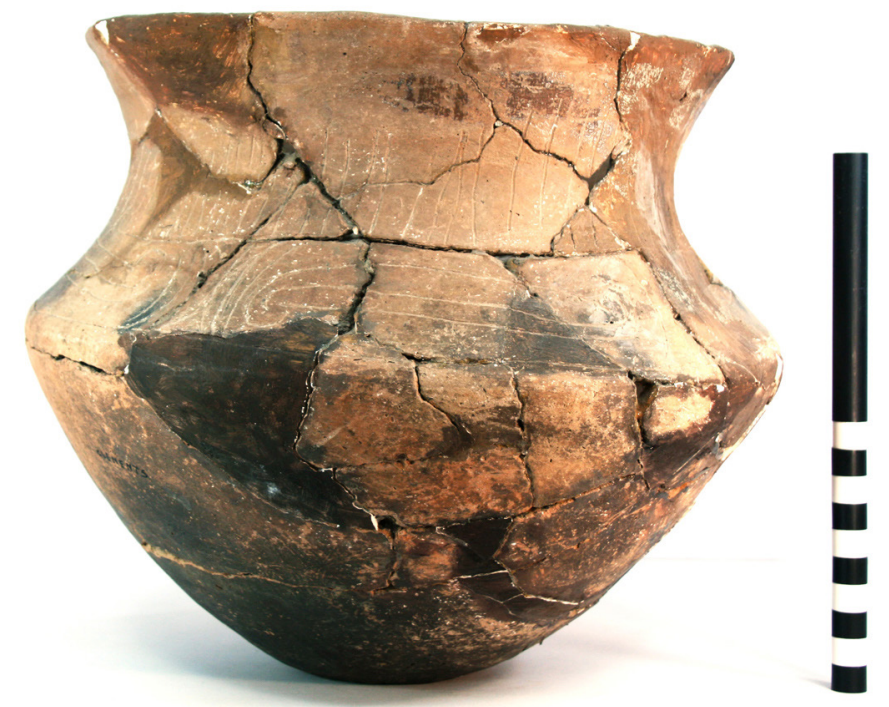

No. X-9) in unknown context at the Clements site.

DECORATION (INCLUDING MOTIF AND ELEMENTS WHEN APPARENT): The upper rim panel of the vessel has a continuous series of vertical engraved lines that extend halfway up the rim panel to the vessel lip (Figure 133). The lower rim panel has a series of four horizontal scrolls with a hooked arm element. These scrolls are divided by four engraved brackets filled with vertical engraved lines (Figure $133)$.

PIGMENT USE AND LOCATION ON VESSEL: none

TYPE AND VARIETY (IF KNOWN): Unidentified fine ware 
SITE NAME OR SITE NUMBER: Clements

VESSEL NO.: X-11, unknown context

VESSEL FORM: Jar

NON-PLASTICS AND PASTE: shell

RIM AND LIP FORM: Everted rim and flat lip; lip notched

CORE COLOR: $\mathrm{G}$ (fired in a reducing environment and cooled in the open air)

INTERIOR SURFACE COLOR: dark grayishbrown

EXTERIOR SURFACE COLOR: reddish-brown; fire clouds on the rim and body

WALL THICKNESS (IN MM): rim, $8.0 \mathrm{~mm}$; body, $8.6 \mathrm{~mm}$

INTERIOR SURFACE TREATMENT: smoothed

EXTERIOR SURFACE TREATMENT: none

HEIGHT (IN CM): 34.1

ORIFICE DIAMETER (IN CM): 27.8

DIAMETER AT BOTTOM OF RIM OR NECK (IN CM): 25.6

BASE DIAMETER (IN CM) AND SHAPE OF BASE: 7.6; circular and concave

ESTIMATED VOLUME (IN LITERS): 11.0

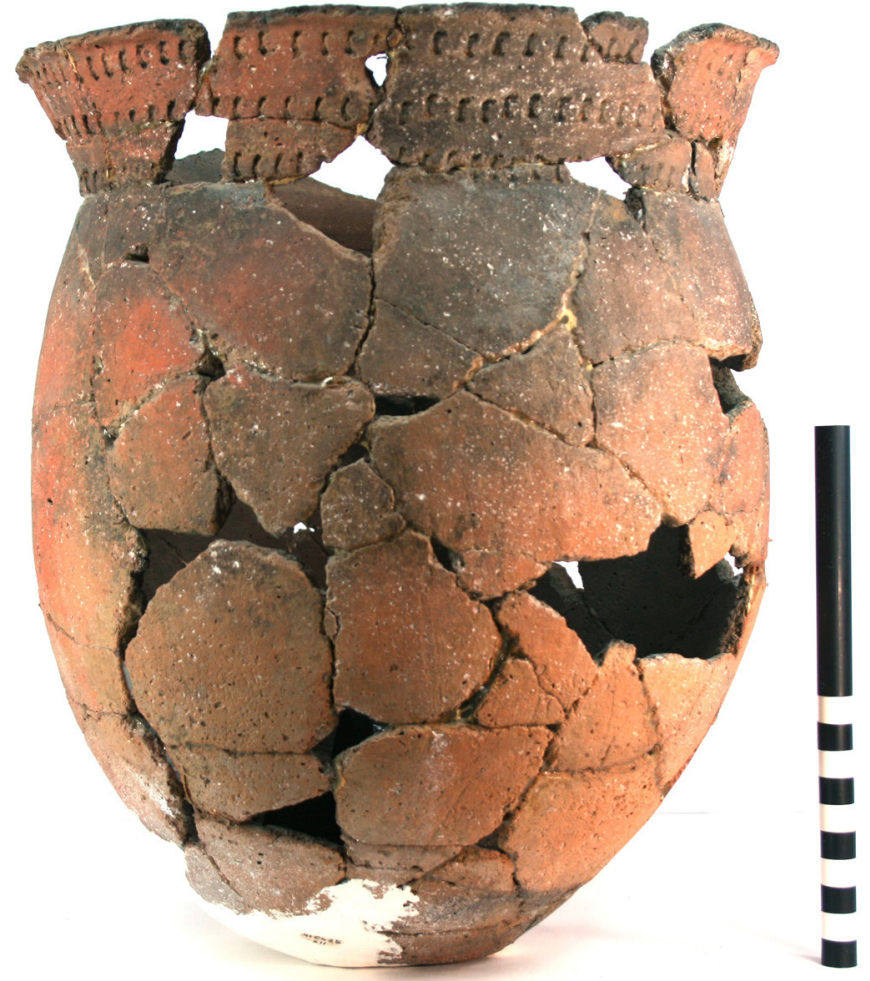

Figure 134. Emory Punctated-Incised jar (Vessel No. $\mathrm{X}-11$ ) in unknown context at the Clements site.

DECORATION (INCLUDING MOTIF AND ELEMENTS WHEN APPARENT): The rim has three horizontal rows of tool punctations (Figure 134).

PIGMENT USE AND LOCATION ON VESSEL: none

TYPE AND VARIETY (IF KNOWN): Emory Punctated-Incised 


\section{Summary and Conclusions}

A total of 153 ceramic vessels have been documented in the various collections from the Goode Hunt (41CS23) and Clements (41CS25) sites (Jackson 1932a, 1932b; Dickinson 1941; Gonzalez et al. 2005; Perttula et al. 2010) in private hands, the American Museum of Natural History, and TARL: 69 vessels from the Goode Hunt cemetery and 84 vessels from the Clements site cemetery. In the summary discussions to follow, functional and stylistic information on the vessels in these collections are used for vessel assemblage comparisons, although temper information is not available from the seven vessels in the Dickinson (1941) collection from the Clements site.

\section{Goode Hunt and Clements Sites Vessel Assemblages}

There are a number of different vessel forms in the Goode Hunt and Clements burial vessel assemblages (Table 5). The most common vessel form at both sites is the jar; this form comprises 30 percent of the Clements site vessels and 36 percent of the Goode Hunt site vessels. This is followed by carinated bowls -25 percent of the Clements site vessels and 36 percent of the Goode Hunt site vessels - and bottles. Almost 20 percent of the 153 vessels from the two sites are bottles, including 14.5 percent of the Goode Hunt site vessel assemblage and 23.8 percent of the Clements site vessel assemblage.

Table 5. Vessel form comparisons.

\begin{tabular}{lrrr}
\hline Vessel Forms & Goode Hunt & Clements & $\mathrm{N}$ \\
\hline Bottle & 10 & 20 & 30 \\
Bowl & 4 & 5 & 9 \\
Carinated Bowl & 25 & 21 & 46 \\
Compound Bowl & 3 & 5 & 8 \\
Deep Bowl & 2 & 2 & 4 \\
Jar & 25 & 6 & 50 \\
Olla & - & 84 & 6 \\
\hline Totals & 69 & 25 & 153 \\
\hline
\end{tabular}

Bowls are rare at both sites in burial contexts, and together they comprise only 5.9 percent of the two vessel assemblages (see Table 5). Overall, ollas are also uncommon vessel forms at the Goode Hunt and Clements sites, and in fact they are only present in a few burials from the Clements site (ollas comprise only 7.1 percent of the vessel assemblage from this site).

Almost 69 percent of the ceramic vessels at the Goode Hunt and Clements sites have been tempered with grog (i.e., crushed sherds) during vessel manufacture (Table 6); these vessels are considered to have been locally made, as are the bone and grog-bone-tempered vessels. At Goode Hunt, the proportion of grog-tempered vessels is 78 percent compared to 60 percent at the Clements site. Another 8.2 percent of the vessels have been tempered with grog and burned bone, and 0.7 percent are tempered with grog and shell (this vessel is likely of non-local manufacture). 
Table 6. Vessel temper comparisons.

\begin{tabular}{lrrr}
\hline Temper categories & Goode Hunt & Clements & $\mathrm{N}$ \\
\hline grog & 54 & 46 & 100 \\
bone & 8 & 8 & 16 \\
grog-bone & 3 & 9 & 12 \\
grog-shell & - & 1 & 1 \\
shell & 4 & 10 & 7 \\
none apparent & - & 77 & 10 \\
\hline Totals & 69 & & 146 \\
\hline
\end{tabular}

Approximately 11 percent of the vessels from the two sites are tempered with burned bone (see Table 6), and 4.8 percent of the vessels are tempered with burned mussel shell. These shell-tempered vessels are from non-local manufacturing contexts, namely they were made by Caddo potters in areas along the Red River in late McCurtain, Belcher, and Chakanina phase contexts where by ca. A.D. 1680 virtually all vessels made by Caddo potters were tempered with mussel shell (see Perttula et al. 2012a; Selden et al. 2014). About 13 percent of the vessels at the Clements site had no apparent temper inclusions.

About 32 percent of the vessels from the two sites are utility wares; another 6.5 percent are plain ware vessels. The utility ware vessels at the Goode Hunt and Clements sites differ in the presence or absence of Cass Appliqued, Clements Brushed, and Emory Punctated-Incised vessels in the two assemblages (Table 7); they are present only in Clements site burials. Given the relatively common occurrence of Clements Brushed vessels and an Emory Punctated jar in burials at the Clements site that have glass trade beads (see below), as well as the absence of glass beads in any of the Goode Hunt site burials, it is suspected that the absence of both Cass Appliqued, Clements Brushed, and Emory Punctated-Incised vessels at the Goode Hunt site is a reflection of the fact that the burials there in part predate (but probably by no more than a generation) many of the burials at the Clements site, and certainly predate those at Clements that have both Clements Brushed and Emory Punctated-Incised vessels and glass trade beads.

Table 7. Utility ware and plain ware vessel comparisons.

\begin{tabular}{lccc}
\hline Types and descriptive categories & Goode Hunt & Clements & N \\
\hline Cass Appliqued & - & 5 & 5 \\
Clements Brushed & - & 5 & 5 \\
Emory Punctated-Incised & - & 2 & 2 \\
Foster Trailed-Incised & 2 & 1 & 3 \\
Karnack Brushed-Incised & 2 & 2 & 4 \\
Maydelle Incised & 2 & - & 2 \\
Mockingbird Punctated & 2 & 5 & 7 \\
Moore Noded & 1 & 1 & 1 \\
Nash Neck Banded & - & 1 & 1 \\
Pease Brushed-Incised & 3 & 1 & 4 \\
& & 1 & 2 \\
Appliqued Jar & 1 & - & 2
\end{tabular}


Table 7. Utility ware and plain ware vessel comparisons, cont.

\begin{tabular}{lccc}
\hline Types and descriptive categories & Goode Hunt & Clements & N \\
\hline Brushed-Appliqued Jar & 2 & - & 2 \\
Brushed-Incised-Appliqued Jar & 1 & - & 1 \\
Brushed-Punctated Jar & - & 1 & 1 \\
Incised Jar & 2 & - & 2 \\
Incised-Appliqued Jar & - & 1 & 1 \\
Incised-Punctated Bottle & - & 1 & 1 \\
Incised-Punctated Jar & 1 & 1 & 2 \\
Pinched-Brushed Jar & - & 1 & 1 \\
Plain Bowl & - & 1 & 1 \\
Plain Carinated bowl & - & 1 & 1 \\
Plain Jar & 6 & 1 & 7 \\
Simms Plain* & - & 33 & 1 \\
\hline Totals & 26 & & 59
\end{tabular}

*see Hamilton 1972

The most common utility ware vessels at both sites include Mockingbird Punctated, Karnack Brushed-Incised, and Pease Brushed-Incised jars, as well as Foster Trailed-Incised jars (see Table 7). There are also a number of jars in the vessel assemblages at both sites that have typologically unidentified appliqued, brushed, brushed-appliqued, brushed-incised-appliqued, brushed-punctated, incised, incised-appliqued, incised-punctated, and pinched-brushed jars; these vessels comprise between 21-40 percent of the utility ware vessels at both sites (see Table 7). There is also an incised-punctated bottle from the Clements site.

Plain vessels are relatively uncommon in the mortuary vessel assemblages at the Goode Hunt and Clements sites (see Table 7). They comprise only between 4.8-8.7 percent of the documented vessels at both sites; most of the plain vessels are jars.

The fine ware vessels from the Goode Hunt and Clements sites represent more than 61 percent of the mortuary vessel assemblages from both sites: 62.3 percent of the Goode Hunt vessels and 60.7 percent of the Clements vessels. The majority of the fine ware vessels at both sites are Simms Engraved and Hodges Engraved carinated bowls or bottles (Table 8). These two types, including the early historic Simms Engraved, var. Darco vessels, comprise more than 60 percent of the fine ware vessels at the two sites. Another important fine ware in the assemblage is Taylor Engraved (4.7 percent of the fine wares at the Goode Hunt site and 11.8 percent of the fine wares at the Clements site), along with Keno Trailed bottles and bowls (Keno Trailed, var. Phillips, an early historic fine ware, see Schambach and Miller 1984:123); Keno Trailed vessels comprise 5.9-7.0 percent of the fine ware vessels in the mortuary vessel assemblages. 
Table 8. Fine ware vessel comparisons.

\begin{tabular}{lccc}
\hline Types and descriptive categories & Goode Hunt & Clements & N \\
\hline Bailey Engraved & 1 & 1 & 2 \\
cf. Cabaness Engraved & 1 & - & 1 \\
Fatherland Incised & - & - & 1 \\
Hatchel Engraved & 2 & 1 & 2 \\
Hatinu Engraved & - & 14 & 1 \\
Hodges Engraved & 8 & - & 22 \\
Hudson Engraved & 1 & 2 & 1 \\
Keno Trailed bottle & 1 & 1 & 3 \\
Keno Trailed, var. Philips & 2 & 12 & 3 \\
Simms Engraved & 17 & 3 & 69 \\
Simms Engraved, var. Darco & 3 & 6 & 8 \\
Taylor Engraved & 2 & 1 & 1 \\
UID Engraved Bottle & & 1 & 2 \\
UID Engraved Bowl & - & 1 & 1 \\
UID Engraved-Appliqued CB & 1 & 1 & 3 \\
UID Engraved Carinated bowl & - & 3 & 5 \\
UID Engraved CPB & 2 & 1 & 1 \\
UID Engraved-Punctated CPB & 2 & 1 & 1 \\
Effigy Bowl & - & 1 & 1 \\
Red-slipped Jar & - & 51 & 94 \\
\hline Totals & - & & \\
\hline
\end{tabular}

UID=unidentified; $\mathrm{CB}=$ carinated bowl $; \mathrm{CPB}=$ compound bowl

The occurrence of Hatchel Engraved vessels in two burials at the Goode Hunt site (see Table 8) is indicative of a limited Late Caddo period use of the cemetery there. This fine ware type is primarily found in pre-A.D. 1550 contexts at the Hatchel and Mitchell sites on the Red River (see Perttula 2014a, 2014c).

There are also a number of engraved, engraved-appliqued, and engraved-punctated vessels - primarily carinated bowls and compound bowls - from both sites that are typologically unidentifiable (see Table 8). These fine ware vessels comprise between 11.6-15.7 percent of the fine ware vessels in the two mortuary assemblages. Rare fine ware vessels, both from the Clements site, include an effigy bowl and a red-slipped jar (see Table 8 ). These vessels represent only 3.9 percent of the fine wares in the mortuary assemblage from Clements.

One of the more distinctive features of the ceramic vessels from the Goode Hunt and Clements sites is that a significant percentage of the vessels are lip notched (Table 9): between 10.7-14.5 percent of the vessels at the two sites. In general, "lip notching is uncommon in Caddo pottery, particularly the fine wares" (Schambach and Miller 1984:123). In the two Cass County Caddo sites, lip notching is present on jars, carinated bowls, compound bowls, and bowls; none of the bottles in the two assemblages have lip notching. The highest proportion of lip notching occurs in fine ware compound bowls (25.0 percent) and the bowls. 
Table 9. Vessel lip notching comparisons.

\begin{tabular}{lccccc}
\hline Site & $\begin{array}{l}\text { Total No./ } \\
\text { Percent }\end{array}$ & Jar & $\begin{array}{c}\text { Carinated } \\
\text { Bowl }\end{array}$ & Compound Bowl & Bowl \\
\hline Goode Hunt & $10 / 14.5$ & 4 & 4 & - & 2 \\
Clements & $9 / 10.7$ & 4 & 2 & 2 & 1 \\
\hline Totals & 19 & 8 & 6 & 2 & 3 \\
$\begin{array}{l}\text { Percent of } \\
\text { Assemblage }\end{array}$ & 12.4 & 16.0 & 13.0 & 25.0 & 33.3 \\
\hline
\end{tabular}

Finally, the five burials from the Clements site that also had European glass beads among the funerary offerings - and thus clearly date after ca. A.D. 1700 - had a total of 13 ceramic vessels. These included three Clements Brushed ollas, two Mockingbird Punctated jars, single examples of utility ware jars - Emory Punctated-Incised, Karnack Brushed-Incised, and brushed-punctated - and single examples of fine ware vessels: a Hodges Engraved deep bowl; a Taylor Engraved deep bowl; a Simms Engraved hubcap style carinated bowl; a Simms Engraved, var. Darco carinated bowl; and an engraved-punctated compound bowl. The presence of Clements Brushed vessels in burials with European trade goods at the Clements site, and the absence of vessels of this type at the Goode Hunt site-and the overall absence of European trade goods at this site-suggests that the burials at this site may date before ca. A.D. 1700, but not much earlier given the overall similarity of the two burial vessel assemblages in the proportions of the most common ceramic types, including Simms Engraved and Hodges Engraved, and the presence of Simms Engraved, var. Darco and Keno Trailed, var. Phillips in both vessel assemblages (see Tables 7 and 8).

\section{Inter-Regional Vessel Assemblage Comparisons}

In historic times, Caddo ceramic vessels, primarily bowls of various forms, jars, and bottles, held liquids and foods. They were also used for cooking and serving foods, such as corn, atole, a corn gruel pounded into a flour and mixed with water or milk (Chapa and Foster 1997:149, fn 6), and tamales (see Swanton 1942:157-158; Chapa and Foster 1997:149). In 1690, Alonso de Leon noted the use of "pots and casserole dishes," filled with beans, corn, and pinole, made of powdered corn and sugar (Chapa and Foster 1997:150, fn 1). Other vessels were reported in historic times to have held incense, body paints/ pigments, and corn meal offerings.

Kelley et al. (1996:92-93) and Kelley (1997) have noted that Caddo mortuary assemblages of vessels along the Red River in Late Caddo period contexts are quite similar to one another, but that they "differ markedly from the domestic assemblage." Late Caddo and early Historic Caddo period Belcher (n=149 vessels) and Cedar Grove ( $\mathrm{n}=63$ vessels) site mortuary assemblages (Webb 1959; Schambach and Miller 1984), from northwestern Louisiana and southwestern Arkansas (Figure 135) contained comparable percentages of bottles (20-24 percent), simple bowls (3-11 percent), carinated bowls (31-37 percent), and jars (32-39 percent) (Kelley et al. 1996:Figure 10). By contrast, the domestic ceramic assemblage from the Joe McLelland site, on the Red River in northwestern Louisiana dated ca. A.D. 1650-1710, is dominated by jars ( 55 percent) and simple bowls ( 27 percent), with much lower proportions of carinated bowls and bottles. 


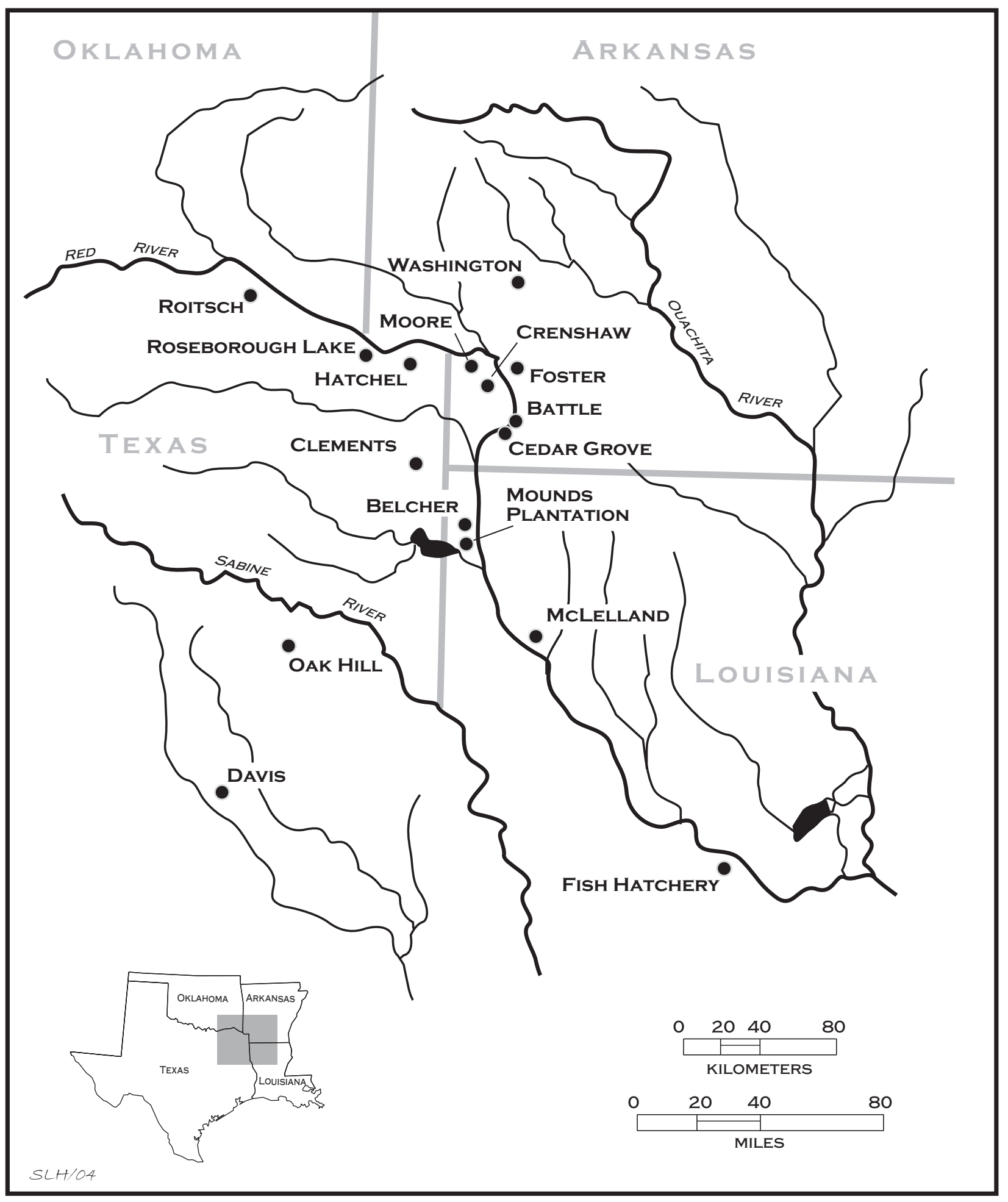

Figure 135. Ancestral Caddo sites with ceramic vessel assemblages mentioned in the text; the Clements and Goode Hunt sites are only a few miles apart. 
The ceramic mortuary assemblages from the Clements and Goode Hunt sites are quite similar to that documented in the Great Bend Red River Late Caddo and early Historic period Caddo cemeteries and vessel assemblages from the Hatchel (41BW3), Mitchell (41BW4), and Eli Moores (41BW2) sites on the Red River in the following respects: (1) a comparable representation of bottles, between 20-27 percent, with most of the graves having a single bottle usually placed near the head; (2) high frequencies of fine ware carinated bowls, compound bowls, and deep bowls (31-38 percent); and (3) comparable proportions of cooking jars (33-34 percent) and simple or conical bowls (6-9 percent) (Table 10). Where they differ is in the relative frequency of ollas, with this form comprising more than 7 percent of the Clements vessels, compared to 1.1 percent for the Belcher and Cedar Grove vessel assemblages (Webb 1959; Schambach and Miller 1984), and no ollas have been reported in the assemblages from the Hatchel, Mitchell, and Eli Moores sites (Perttula 2014a, 2014b, 2014c). Ollas are also not generally well represented in the vessel assemblages from other Late Caddo or early Historic Caddo period cemeteries, other than from certain Titus phase sites in northeastern Texas. At cemeteries that have ollas, they occur in the Big Cypress subcluster in the Lake O' the Pines area along Big Cypress Creek and tributaries (cf. Thurmond 1990) as well as in low frequencies on post-A.D. 1550 Titus phase sites on Little Cypress Creek in the Gum Creek cluster (see Perttula et al. 2012b).

Table 10. Late Caddo and early Historic Caddo period mortuary vessel assemblages, including those from the Clements and Goode Hunt sites.

\begin{tabular}{|c|c|c|c|c|c|c|c|}
\hline \multirow[t]{2}{*}{ Region } & \multirow[t]{2}{*}{$\mathrm{N}$} & \multirow[b]{2}{*}{ Bottle } & \multicolumn{3}{|c|}{ Vessel Forms } & \multirow[b]{2}{*}{$\begin{array}{c}\text { Cooking } \\
\text { Jar }\end{array}$} & \multirow[t]{2}{*}{ Reference } \\
\hline & & & $\begin{array}{c}\text { Simple } \\
\text { Bowl }\end{array}$ & $\begin{array}{c}\text { Carinated } \\
\text { Bowl/Compound } \\
\text { Bowl/Deep Bowl }\end{array}$ & $\begin{array}{c}\text { Seed } \\
\text { Jar }\end{array}$ & & \\
\hline \multicolumn{8}{|l|}{ Clements and } \\
\hline Goode Hunt & 153 & $20 *$ & 6 & 38 & 0 & 33 & $\begin{array}{l}\text { This report; } \\
\text { Jackson 1932a, b; } \\
\text { Dickinson 1941; } \\
\text { Perttula et al. 2010 }\end{array}$ \\
\hline \multicolumn{8}{|l|}{ Red River, } \\
\hline $\begin{array}{l}\text { Hatchel, Mitchell, } \\
\text { Moores sites }\end{array}$ & 151 & 27 & 9 & 31 & 0 & 34 & $\begin{array}{l}\text { Perttula 2014a, } \\
\text { 2014b, 2014c }\end{array}$ \\
\hline $\begin{array}{l}\text { Red River, } \\
\text { Great Bend }\end{array}$ & 212 & 23 & 5 & 36 & 0 & 36 & $\begin{array}{l}\text { Webb 1959; } \\
\text { Schambach \& } \\
\text { Miller } 1984\end{array}$ \\
\hline \multicolumn{8}{|l|}{ Mineral } \\
\hline Springs** & 91 & 24 & 10 & 37 & 1 & 27 & Bohannon 1973 \\
\hline \multicolumn{8}{|l|}{ Red River, } \\
\hline Mound Prairie & 690 & 15 & 44 & 13 & 0 & 28 & $\begin{array}{l}\text { Perino 1981, } \\
\text { 1983, 1994, } 1995 \\
\text { Skinner et al. } 1969\end{array}$ \\
\hline Mill Creek*** & 14 & 14 & 36 & 14 & 0 & 36 & Webb 1983 \\
\hline
\end{tabular}


Table 10. Late Caddo and early Historic Caddo period mortuary vessel assemblages, including those from the Clements and Goode Hunt sites, cont.

\begin{tabular}{|c|c|c|c|c|c|c|c|}
\hline \multirow[t]{2}{*}{ Region } & \multirow[t]{2}{*}{$\mathrm{N}$} & \multirow[b]{2}{*}{ Bottle } & \multicolumn{3}{|c|}{ Vessel Forms } & & \multirow[t]{2}{*}{ Reference } \\
\hline & & & $\begin{array}{c}\text { Simple } \\
\text { Bowl }\end{array}$ & $\begin{array}{c}\text { Carinated } \\
\text { Bowl/Compound } \\
\text { Bowl/Deep Bowl }\end{array}$ & $\begin{array}{c}\text { Seed } \\
\text { Jar }\end{array}$ & $\begin{array}{c}\text { Cooking } \\
\text { Jar }\end{array}$ & \\
\hline Hardman/Helm & 63 & 33 & 14 & 30 & 2 & 21 & $\begin{array}{l}\text { Early 1993; } \\
\text { Lafferty et al. } 2000\end{array}$ \\
\hline Standridge & 22 & 41 & 9 & 18 & 0 & 32 & Early 1988 \\
\hline Wright Patman & 36 & 42 & 9 & 6 & 0 & 42 & Jelks $1961 * * * *$ \\
\hline Titus Phase & 1816 & 10 & 10 & 50 & 0 & 30 & $\begin{array}{l}\text { Thurmond 1990; } \\
\text { Turner 1978; } \\
\text { Perttula et al. 1998; } \\
\text { Perttula (ed.) } \\
2005 * * * * *\end{array}$ \\
\hline $\begin{array}{l}\text { Little Cypress- } \\
\text { Titus phase }\end{array}$ & 465 & 14 & 8 & 50 & 0 & 28 & $\begin{array}{l}\text { Perttula et al. } \\
2012 b, 2012 c\end{array}$ \\
\hline \multicolumn{8}{|l|}{ Frankston- } \\
\hline Allen phase & 447 & 13 & 55 & 16 & + & 16 & $\begin{array}{l}\text { Shafer 1981; } \\
\text { Kleinschmidt } \\
\text { 1982; Fields 1995; } \\
\text { Perttula et al. 2011 }\end{array}$ \\
\hline Toledo Bend & 112 & 27 & 19 & 30 & 0 & 24 & $\begin{array}{l}\text { McClurkan et al. } \\
\text { 1966; Woodall } \\
1969\end{array}$ \\
\hline Kinsloe phase & 88 & 20 & 44 & 1 & 0 & 34 & Jones 1968 \\
\hline
\end{tabular}

$+=$ trace; $*$ percentage $* *$ burials from the Saratoga phase (see also Hoffman 1983); *** Bossier phase; $* * *$ includes vessels from the Knight's Bluff and Sherwin sites ***** includes vessels from the Mockingbird ( $\mathrm{n}=89$ ), Tuck Carpenter ( $\mathrm{n}=383$ ), Mattie Gandy $(n=79)$, H. R. Taylor ( $n=413)$, Ben McKinney ( $n=86)$, A. P. Williams ( $n=78)$, Thomas Caldwell ( $n=88)$, J. M. Riley ( $n=131)$, and $\mathrm{W}-\mathrm{S}(\mathrm{n}=317)$ sites.

Fundamental differences in morphology and shape between ceramic vessels have been recognized for many years in Caddo archaeological research, and these differences seem to have clear functional and social connotations (see Early 1995; Perttula 2000). Late Caddo period ceramic mortuary assemblages also differ considerably from region to region within the Caddoan archaeological area in the composition of jars, bottles, bowls, and carinated bowls. In particular, an examination of Late Caddo and early Historic Caddo mortuary vessel assemblages from some 50+ Caddo cemetery sites (and about 4375 vessels, including 153 from the Clements and Goode Hunt sites) in the Great Bend, Bowie County, and Mound Prairie areas on the Red River, the Little River area and Ouachita River area in southwestern Arkansas, the lower Sulphur River, the middle Sabine region, the upper Neches/Angelina river area, and 
the Pineywoods and Post Oak Savanna Titus phase region disclose consistent differences from area to area among contemporaneous Late Caddo and early Historic period Caddo groups (see Table 10).

As already noted, there is not much difference between the Clements and Goode Hunt sites and contemporaneous Belcher phase, Texarkana phase, and Chakanina phase cemeteries on the Great Bend of the Red River in the character of mortuary ceramic vessel assemblages, although they are not identical in composition. This close similarity in mortuary vessel composition probably indicates strong shared social, religious, and philosophical beliefs that existed among many Nasoni Caddo and Red River Caddo peoples and communities in the kinds of ceramic vessels important for use in life, and also of need in the after-life, as well as the existence of widespread personal and social contacts between different Caddo peoples; several vessels at the Goode Hunt and Clements site have their origins among different Caddo groups along the Red River to the north and east. The mortuary vessel assemblages from the Clements and Goode Hunt sites are distinctive among other Late Caddo and early Historic period Caddo groups, in that they are uniformly dominated by carinated bowls/compound bowls of various sizes and jars, with a consistent and a relatively comparable representation of both bottles, jars, and Clements Brushed ollas (see Table 10).

No other contemporaneous Caddo mortuary vessel assemblage from other Caddo groups across the southern Caddo archaeological area resembles in all aspects that from the Clements and Goode Hunt sites. This can only mean that there was a very considerable diversity among Caddo groups in their cultural practices, beliefs, and world-views about what males and females - and adults and children - needed in life, and "needed in the other life" (Swanton 1942:205), and that there were cultural, social, and personal boundaries between Caddo groups not regularly crossed by networks of personal and group contacts.

The Nasoni Caddo groups that used the Clements and Goode Hunt sites for burials obviously had a basic need for food-serving vessels (particularly medium and large carinated bowls), as did their Caddo neighbors in the Neches-Angelina river basins well to the south (though they preferred carinated, globular, and shouldered engraved bowls of the Poynor and Patton Engraved types), the Caddo living on the Mound Prairie area along the Red River to the northwest (i.e., McCurtain phase), and the Titus phase Caddo groups in the Big Cypress Creek and Little Cypress Creek basins to the southwest. Perhaps this was a legacy of feasting behavior, or other cultural activities centered around the ritual consumption of food that was not shared among other Caddo peoples. Among the aforementioned Caddo groups, simple bowls and carinated bowls comprised between 57-70 percent of the vessels placed in the graves as burial offerings (see Table 10).

At the Clements and Goode Hunt sites, simple bowls, deep bowls, carinated bowls, and compound bowls comprise 44 percent of all the vessels from these two sites. This is generally more than was the case along the lower Sulphur River, the Great Bend area of the Red River, and in the Ouachita River drainage in Southwest Arkansas, where the proportions of bowls and carinated bowls ranged from 15-47 percent of the vessel assemblages. In the latter areas, the Caddo assemblages with the highest proportions of serving bowls in mortuary contexts include the Mineral Springs site (47 percent) and sites in the Great Bend of the Red River (41 percent) (see Table 10).

Cooking and storage jars are ubiquitous in all Late Caddo and early Historic Caddo period mortuary contexts, including that of the Clements and Goode Hunt sites, where they amount to 33 percent of the mortuary vessel assemblages (see Table 10). This consistent use of jars highlights the importance of cooking and storage vessels for sustaining Caddo agricultural lifeways, as well as for insuring that the individual in the grave had enough foodstuffs (placed in the jars) to sustain themselves on their journey to the House of Death in the Sky (cf. Swanton 1942:204, 210). 
Bottles, probably used for holding liquids, corn meal, and other kinds of offerings, were especially important burial accompaniments for Late Caddo and early Historic period Caddo populations living in the Ouachita River basin in southwestern Arkansas (see Early 1988, 1993; Lafferty et al. 2000), the Little River basin, the lower Sulphur River in northeastern Texas, and in cemeteries along the Great Bend of the Red River. Bottles comprised between 23-42 percent of the ceramic mortuary offerings for these Caddo groups (see Table 10). At the Clements and Goode Hunt sites, bottles of several different forms comprise 19.6 percent of the ceramic mortuary vessels. Significantly, the common incorporation of bottles as funerary offerings was not the case among the Titus phase Caddo peoples living in the Pineywoods and Post Oak Savanna of northeastern Texas, the Frankston-Allen phase Caddo in East Texas, or the Caddo groups living in the Mound Prairie area of the Red River in northeastern Texas. Among these westernmost Caddo groups, the percentage of bottles among the ceramic mortuary assemblages ranged from only 10-15 percent, two to three times less than certain Late Caddo and early Historic Caddo period groups living farther to the east and northeast in parts of the Red River basin, the Little River, and the Ouachita River (see Figure 135).

In fact, there appears to be a clear inverse relationship in Caddo mortuary contexts from these 50+ cemeteries across the eastern and western parts of the Caddoan area in the relative proportions of bottles to bowls in the mortuary vessel assemblages; the proportions of jars remain relatively consistent from one assemblage to another. The Clements and Goode Hunt sites fall between these eastern and western Caddo groups in these respects. This inverse relationship would seem to express a basic dichotomy in belief and cultural practices manifest in burial practices (i.e., vessels as funerary offerings) between eastern and western Caddo groups and in the archaeological sites associated with these different Caddo groups. This is a dichotomy that further expresses the existence of well-defined social boundaries in Late Caddo and early Historic Caddo period times (and perhaps even into earlier Middle Caddo period times), and provides insights into the complexity of the Caddo cultural landscape that was in place around and shortly after their first sustained contact with Europeans.

In conclusion, the ceramic vessels were commonly placed as funerary offerings in most of the individual burials at the Caddo cemeteries at the Goode Hunt (41CS23) and Clements (41CS25) sites in the eastern part of the Big Cypress Creek basin in the East Texas Pineywoods. These burials appear to be the product of Nasoni Caddo mortuary practices, and ceramic vessels were common funerary offerings; the mean number of vessels is about four vessels per burial. Although there are no radiocarbon dates available from any of these burials, the decorative styles and distinctive vessel forms represented in the two ceramic vessel assemblages suggest that the burials were generally contemporaneous, dating from ca. A.D. 1680-1730, in the early Historic Caddo period, although two of the burials at the Goode Hunt site with Hatchel Engraved vessels may date earlier in the Late Caddo period.

The vessels from these two Nasoni Caddo cemeteries are primarily grog-tempered, as well as bonetempered. The few shell-tempered vessels - representing about 5 percent of the vessel assemblages - are thought to have been manufactured by Caddo potters living along the Red River to the north and east of the Goode Hunt and Clements sites (among Belcher, McCurtain, and Chakanina phase Caddo groups) and then traded/exchanged with the Nasoni Caddo groups living in the immediate vicinity of these two cemeteries. The mortuary assemblages at the two sites are dominated by fine ware vessels - including carinated bowls, compound bowls, bottles, bottles, and deep bowls - with engraved decorative elements. In both sites, the principal fine wares are Simms Engraved (of several undefined varieties), Simms Engraved, var. Darco, and Hodges Engraved carinated bowls or bottles. Other common fine wares at the two cemeteries are Taylor Engraved and Keno Trailed (including var. Phillips) carinated bowls, bottles, or bowls. The most common utility ware vessels at both sites include Mockingbird Punctated, Karnack Brushed-Incised, and Pease Brushed-Incised jars, as well as Foster Trailed-Incised, var. Moore jars. 
Clements Brushed and Cass Appliqued jars are present in burials only at the Clements site. Finally, plain vessels are relatively uncommon in the mortuary vessel assemblages at the Goode Hunt and Clements sites, and most of the plain vessels are small to medium-sized jars. 


\section{References Cited}

Bohannon, C. F.

1973 Excavations at the Mineral Springs Site, Howard County, Arkansas. Research Series No. 5. Arkansas Archeological Survey, Fayetteville.

Brain, J. P.

1988 Tunica Archaeology. Volume 78. Papers of the Peabody Museum of Archaeology and Ethnology. Peabody Museum of Archaeology and Ethnology, Harvard University, Cambridge.

Brown, I. W.

1998 Decorated Pottery of the Lower Mississippi Valley: A Sorting Manual. Mississippi Archaeological Association and Mississippi Department of Archives and History, Jackson.

Cast, R., T. K. Perttula, B. Gonzalez, and B. Nelson

2005 A Rediscovery of Caddo Heritage: The W. T. Scott Collection at the American Museum of Natural History. Caddoan Archeology Journal 14:5-16.

2006 A Rediscovery of Caddo Heritage. Archaeologies: The Journal of the World Archaeological Congress 2(1):45-51.

Chapa, J. B. and W. C. Foster (editor)

1997 Texas \& Northeastern Mexico, 1630-1690. University of Texas Press, Austin.

Cole, N. M.

1975 Early Historic Caddoan Mortuary Practices in the Upper Neches Drainage, East Texas. Master's thesis, Department of Anthropology, The University of Texas at Austin.

Creel, D. G.

1982 Artifacts of Non-Native Manufacture. In The Deshazo Site, Nacogdoches County, Texas, Volume 1, edited by D. A. Story, pp. 113-130. Texas Antiquities Permit Series, No. 7. Texas Antiquities Committee, Austin.

Dickinson, S. D.

1936 Ceramic Relationships of the Pre-Caddo Pottery from the Crenshaw Site. Bulletin of the Texas Archeological and Paleontological Society 8:56-69.

1941 Certain Vessels from the Clements Place, a Historic Caddo Site. Bulletin of the Texas Archeological and Paleontological Society 13:117-134.

Dickinson, S. D. and H. J. Lemley

1939 Evidences of the Marksville and Coles Creek Complexes at the Kirkham Place, Clark County, Arkansas. Bulletin of the Texas Archeological and Paleontological Society 11:139-189.

Early, A. M. (editor)

1988 Standridge: Caddoan Settlement in a Mountain Environment. Research Series No. 29. Arkansas Archeological Survey, Fayetteville.

1993 Caddoan Saltmakers in the Ouachita Valley: The Hardman Site. Research Series No. 43. Arkansas Archeological Survey, Fayetteville. 
1995 Regional Change, Cultural Boundaries, and Worlds of Thought: New Approaches Toward Caddoan Ceramics. Paper presented at the 1995 Caddo Conference, Austin.

Fields, R. C.

1995 Analysis of Native-Made Ceramics. In The Deshazo Site, Nacogdoches County, Texas, Volume 2: Artifacts of Native Manufacture, edited by D. A. Story, pp. 173-232. Studies in Archeology 21. Texas Archeological Research Laboratory, The University of Texas at Austin.

Foster, W. C. (editor)

1998 The La Salle Expedition to Texas: The Journal of Henri Joutel, 1684-1687. Texas State Historical Association, Austin.

Gadus, E. F.

2013 Twisted Serpents and Fierce Birds: Structural Variation in Caddo Engraved Ceramic Bottle Motifs. Bulletin of the Texas Archeological Society 84:213-245.

Gonzalez, B., R. L. Cast, T. K. Perttula, and B. Nelson

2005 A Rediscovering of Caddo Heritage: The W. T. Scott Collection at the American Museum of Natural History and Other Caddo Collections from Arkansas and Louisiana. Historic Preservation Program, Caddo Nation of Oklahoma, Binger.

Hamilton, D. L.

1972 Analysis of the Engraved Ceramics from the A. H. Hatchel Place, Bowie County, Texas. MS on file, Texas Archeological Research Laboratory, The University of Texas at Austin.

Harris, R. K., I. M. Harris, J. C. Blaine, and J. Blaine

1965 A Preliminary Archeological and Documentary Study of the Womack Site, Lamar County, Texas. Bulletin of the Texas Archeological Society 36:287-363.

Hoffman, M. P.

1983 Changing Mortuary Patterns in the Little River Region, Arkansas. In Southeastern Natives and Their Pasts: A Collection of Papers Honoring Dr. Robert E. Bell, edited by D. G. Wyckoff and J. L. Hofman, pp. 163-182. Studies in Oklahoma's Past No. 11. Oklahoma Archeological Survey, Norman.

Jackson, A. T.

1932a Exploration of a burial site on Clements Bros. Farm in Cass County, Texas. MS on file, Texas Archeological Research Laboratory, The University of Texas at Austin.

1932b Exploration of a burial site on Goode Hunt Farm in Cass County, Texas. MS on file, Texas Archeological Research Laboratory, The University of Texas at Austin.

Jelks, E. B.

1961 Excavations in Texarkana Reservoir, Sulphur River, Texas. River Basin Survey Papers No. 21. Bulletin 179. Bureau of American Ethnology, Smithsonian Institution, Washington, D.C.

Jones, B. C.

1968 The Kinsloe Focus: A Study of Seven Historic Caddoan Sites in Northeast Texas. Master's thesis, Department of Anthropology, University of Oklahoma, Norman. 
Kay, M.

1984 Late Caddo Subtractive Technology in the Red River Basin. In Cedar Grove: An Interdisciplinary Investigation of a Late Caddo Farmstead in the Red River Valley, edited by N. L. Trubowitz, pp. 174-206. Research Series No. 23. Arkansas Archeological Survey, Fayetteville.

Kelley, D. B.

2012 The Belcher Phase: Sixteenth- and Seventeenth-Century Caddo Occupation of the Red River Valley in Northwest Louisiana and Southwest Arkansas. In The Archaeology of the Caddo, edited by T. K. Perttula and C. P. Walker, pp. 411-430. University of Nebraska Press, Lincoln.

Kelley, D. B. (editor)

1997 Two Caddoan Farmsteads in the Red River Valley: The Archeology of the McLelland and Joe Clark Sites. Research Series No. 51. Arkansas Archeological Survey, Fayetteville.

Kelley, D. B., D. G. Hunter, P. S. Gardner, D. C. Weinand, A. Tine, and L. L. Tieszen

1996 The McLelland and Joe Clark Sites: Protohistoric-Historic Caddo Farmsteads in the Red River Valley of Northwest Louisiana. Southeastern Archaeology 15:81-102.

Kenmotsu, N. A., J. E. Bruseth, and J. E. Corbin

1993 Moscoso and the Route in Texas: A Reconstruction. In The Expedition of Hernando de Soto West of the Mississippi, 1541-1543: Proceedings of the De Soto Symposia 1988 and 1990, edited by G. A. Young and M. P. Hoffman, pp. 106-131. University of Arkansas Press, Fayetteville.

Kidd, K. E. and M. A. Kidd

1970 A Classification System for Glass Beads for the Use of Field Archaeologists. Occasional Papers in Archaeology and History, No. 1, pp. 45-89. National Historic Sites Service, National and Historic Parks Branch, Department of Indian Affairs and Northern Development, Ottawa, Ontario.

Kleinschmidt, U. K. W.

1982 Review and Analysis of the A. C. Saunders Site, 41AN19, Anderson County, Texas. Master's thesis, Department of Anthropology, The University of Texas at Austin.

Lafferty, R. H., III, A. Early, M. C. Sierzchula, M. C. Hill, G. S. Powell, N. H. Lopinot, L. S. Cummings, S. L. Scott, S. K. Nash, and T. K. Perttula

2000 Data Recovery at the Helm Site, 3HS449, Hot Spring County, Arkansas. MCRA Report 2000-1. Mid-Continental Research Associates, Inc., Lowell, Arkansas.

Lemley, H. J.

1936 Discoveries Indicating a Pre-Caddo Culture on Red River in Arkansas. Bulletin of the Texas Archeological and Paleontological Society 8:25-55.

Lewis, G. A.

1987 The Clements Brothers' Farm Site (41CS25). Master's thesis, Department of Anthropology, The University of Texas at Austin.

McClurkan, B. B., W. T. Field, and J. N. Woodall

1966 Excavations in Toledo Bend Reservoir: 1964-65. Papers of the Texas Archeological Salvage Project, No. 8. Texas Archeological Salvage Project, The University of Texas at Austin. 
Moore, C. B.

1909 Antiquities of the Ouachita Valley. Journal of the Academy of Natural Sciences of Philadelphia 14:1-170.

1912 Some Aboriginal Sites on Red River. Journal of the Academy of Natural Sciences of Philadelphia 14:481-644.

Perino, G.

1981 Archeological Investigations at the Roden Site, McCurtain County, Oklahoma. Publication No. 1. Potsherd Press, Museum of the Red River, Idabel, Oklahoma.

1983 Archaeological Research at the Bob Williams Site, Red River County, Texas. Potsherd Press, Museum of the Red River, Idabel, Oklahoma.

1994 Archaeological Research at the Rowland Clark Site (41RR77), Red River County, Texas. Journal of Northeast Texas Archaeology 4:3-42.

1995 The Dan Holdeman Site (41RR11), Red River County, Texas. Journal of Northeast Texas Archaeology 6:3-65.

Perttula, T. K.

1992 “The Caddo Nation”: Archaeological \& Ethnohistoric Perspectives. University of Texas Press, Austin.

1993 Effects of European Contact on Native and Immigrant Indians in Northeast Texas. In Archeology in the Eastern Planning Region, Texas: A Planning Document, edited by N. A. Kenmotsu and T. K. Perttula, pp. 147-187. Cultural Resource Management Report 3. Department of Antiquities Protection, Texas Historical Commission, Austin.

2000 Functional and Stylistic Analyses of Ceramic Vessels from Mortuary Features at a $15^{\text {th }}$ and $16^{\text {th }}$ Century Caddo Site in Northeast Texas. Midcontinental Journal of Archaeology 25(1):101-151.

200541 HO64/41HO65, Late $17^{\text {th }}$ to Early $18^{\text {th }}$ Century Caddo Sites on San Pedro Creek in Houston County, Texas. Bulletin of the Texas Archeological Society 75:85-103.

2014a The Mitchell Site (41BW4): An Ancestral Caddo Settlement and Cemetery on McKinney Bayou, Bowie County, Texas. Special Publication No. 32. Friends of Northeast Texas Archaeology, Austin and Pittsburg.

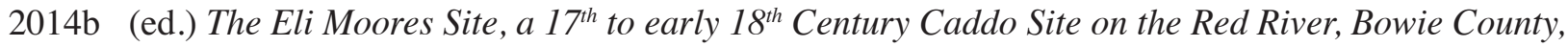
Texas. Special Publication No. 31. Friends of Northeast Texas Archaeology, Austin and Pittsburg.

2014c Archaeological Studies of the Hatchel Site (41BW3) on the Red River in Bowie County, Texas. Special Publication No. 23. Friends of Northeast Texas Archaeology, Austin and Pittsburg.

Perttula, T. K. (editor)

2005 Archeological Investigations at the Pilgrim's Pride Site (41CP304), a Titus Phase Community in the Big Cypress Creek Basin, Camp County, Texas. 2 Vols. Report of Investigations No. 30. Archeological \& Environmental Consultants, LLC, Austin.

Perttula, T. K. and L. Green

2006 Marine Shell Ear Disks from Protohistoric Caddo Sites on Stouts Creek, Hopkins County, Texas. Journal of Northeast Texas Archaeology 25:19-25. 
Perttula, T. K., D. B. Kelley, and R. A. Ricklis (assemblers and editors)

2011 Archeological Investigations at the Lang Pasture Site (41AN38) in the Upper Neches River Basin of East Texas. Report No. 129. Texas Department of Transportation, Archeological Studies Program, Environmental Affairs Division, Austin.

Perttula, T. K., B. Nelson, and M. Walters

2012c Caddo Archaeology at the Henry Spencer Site (41UR315) in the Little Cypress Creek Basin of East Texas. Special Publication No. 20. Friends of Northeast Texas Archaeology, Pittsburg and Austin.

Perttula, T. K., B. Nelson, R. L. Cast, and B. Gonzalez

2010 The Clements Site (41CS25): A Late 17 th to Early $18^{\text {th }}$-Century Nasoni Caddo Settlement and Cemetery. Anthropological Papers No. 92. American Museum of Natural History, New York.

Perttula, T. K., M. Tate, H. Neff, J. W. Cogswell, M. D. Glascock, E. Skokan, S. Mulholland, R. Rogers, and B. Nelson

1998 Analysis of the Titus Phase Mortuary Assemblage at the Mockingbird or "Kahbakayammaahin" Site (41TT550). Document No. 970849. Espey, Huston \& Associates, Inc., Austin.

Perttula, T. K., M. B. Trubitt, and J. S. Girard

2012a The Use of Shell-Tempered Pottery in the Caddo Area of the Southeastern United States. Southeastern Archaeology 30(2):242-267.

Perttula, T. K., M. Walters, and B. Nelson

2012b Little Cypress Creek Basin Archaeology: Six Late Caddo Period Cemeteries in Upshur County, Texas. Special Publication No. 22. Friends of Northeast Texas Archaeology, Pittsburg and Austin.

Schambach, F. F. and J. E. Miller III

1984 A Description and Analysis of the Ceramics. In Cedar Grove: An Interdisciplinary Investigation of a Late Caddo Farmstead in the Red River Valley, edited by N. L. Trubowitz, pp. 109-170. Research Report No. 23. Arkansas Archeological Survey, Fayetteville.

Selden, R. Z., Jr., T. K. Perttula, and D. L. Carlson

2014 INAA and the Provenance of Shell-Tempered Sherds in the Ancestral Caddo Region. Journal of Archaeological Science 47:113-120.

Shafer, H. J.

1981 Archeological Investigations at the Attaway Site, Henderson County, Texas. Bulletin of the Texas Archeological Society 52:147-178.

Skinner, S. A., R. K. Harris, and K. M. Anderson (editors)

1969 Archaeological Investigations at the Sam Kaufman Site, Red River County, Texas. Contributions in Anthropology No. 5. Department of Anthropology, Southern Methodist University, Dallas.

Swanton, J. R.

1942 Source Material on the History and Ethnology of the Caddo Indians. Bulletin 132. Bureau of American Ethnology, Smithsonian Institution, Washington, D.C.

Teltser, P. A.

1993 An Analytic Strategy for Studying Assemblage-Scale Ceramic Variation: A Case Study from Southeast Missouri. American Antiquity 58(3):530-543. 
Thurmond, J. P.

1990 Archeology of the Cypress Creek Drainage Basin, Northeastern Texas and Northwestern Louisiana. Studies in Archeology 5. Texas Archeological Research Laboratory, The University of Texas at Austin.

Trubowitz, N. L. (editor)

1984 Cedar Grove: An Interdisciplinary Investigation of a Late Caddo Farmstead in the Red River Valley. Research Series No. 23. Arkansas Archeological Survey, Fayetteville.

Turner, R. L.

1978 The Tuck Carpenter Site and Its Relation to Other Sites Within the Titus Focus. Bulletin of the Texas Archeological Society 49:1-110.

Webb, C. H.

1959 The Belcher Mound: A Stratified Caddoan Site in Caddo Parish, Louisiana. Memoirs No. 16. Society for American Archaeology, Salt Lake City.

1983 The Bossier Focus Revisited: Montgomery I, Werner, and Other Unicomponent Sites. In Southeastern Natives and Their Pasts: A Collection of Papers Honoring Dr. Robert E. Bell, edited by D. G. Wyckoff and J. L. Hofman, pp. 183-240. Studies in Oklahoma's Past No. 11. Oklahoma Archeological Survey, Norman.

Woodall, J. N.

1969 Archeological Excavations in the Toledo Bend Reservoir, 1966. Contributions in Anthropology No. 3. Department of Anthropology, Southern Methodist University, Dallas. 